


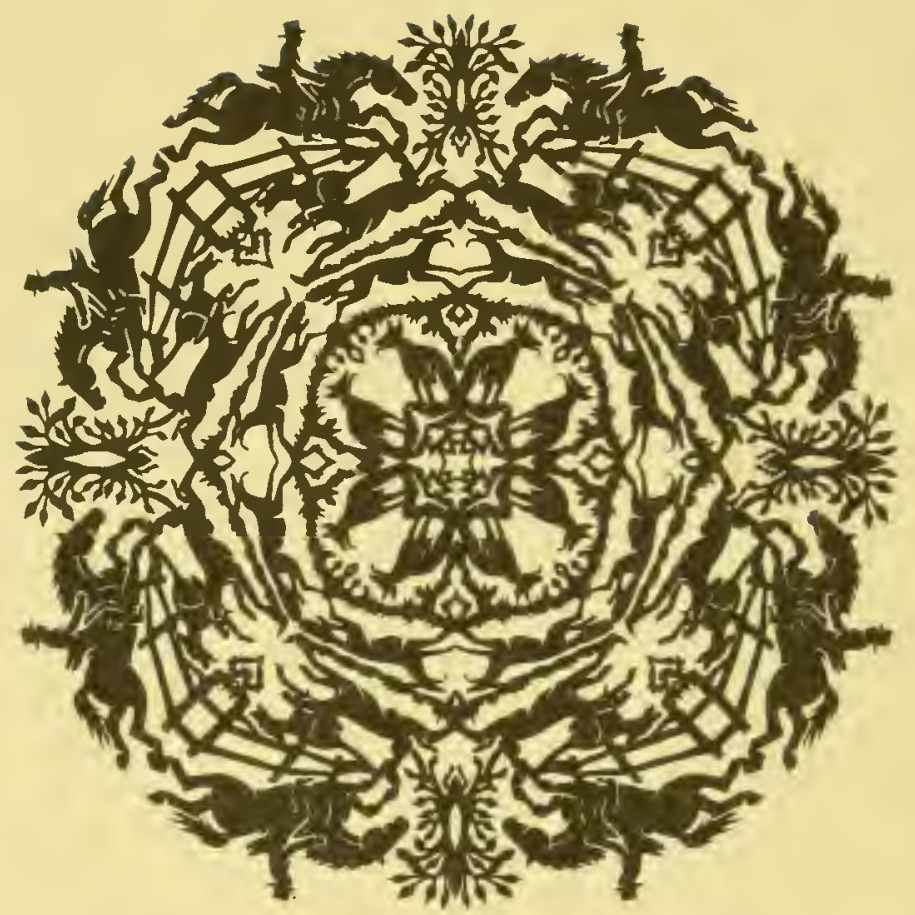

JOHN A.SEAVERNS 
TUFTS UNIVERSITY LIBRARIES

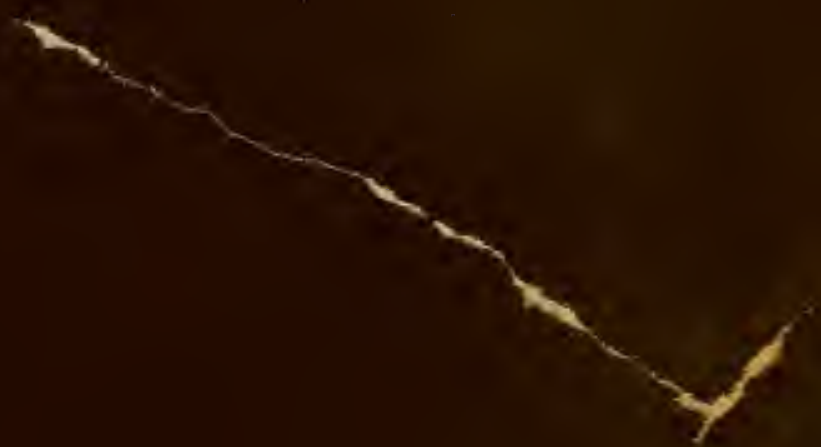





Webster Family Library of Veterinary Madicin Cummings School of Vaterinary Medicine at

Tuifs University 200 Westboro Road

Alorth Grafton, MA 0155 


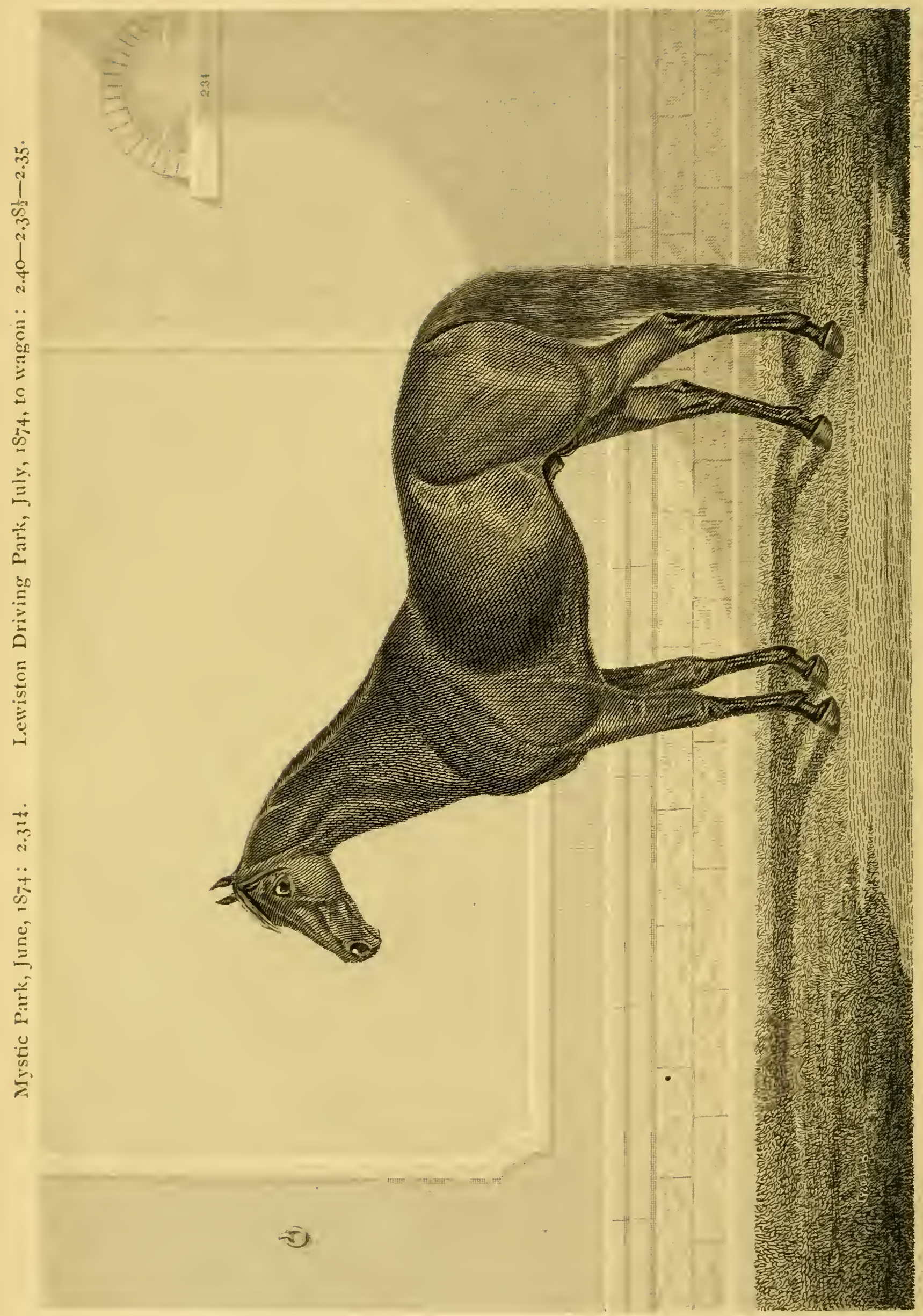




\section{SKETCHES,}

\section{HISTORICAL AND DESCRIPTIVE,}

\section{OF \\ NOTED MAINE HORSES,}

PAST AND PRESENT,

THEIR ANCESTORS AND DESCENDANTS.

BY J. W. THOMPSON.

With an Alphabetical Index, a list of Maine 2.30 horses, alphabetically arranged, and the Laze passed by the Fifty-second Legislature, ontitled, an Act for the Better Preservation of Horse Records.

PORTLAND:

HOYT \& FOGG, PUBLISHERS.

1874 . 
Entered according to act of Congress in the year 1874 , by $\mathrm{J}$. W. Thompson, in the Office of the Librarian of Congress, at Washington, D. C.

B. THURSTON \& CO., PRINTERS, PORTLAND, ME。 


\section{CONTENTS.}

PAGE.

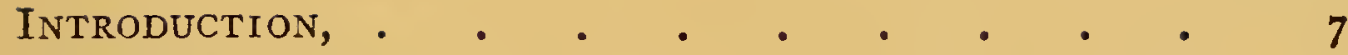

MESSENGER STOCK, • • • . . . . . . 25

MORGAN STOCK, • • • • • • • . 49

DrEW STOCK, . . . . . . . . . 60

EATON STOCK, • • • • • • . • . 9 . 9

Rising SUN STOCK, • • • • • • • •

Flying EATON STOCK, • • • • • • • III

BRANDYWINE STOCK, • • • • • • • II5

KNOX STOCK, • • . • . . . . . I23

BLACK HAWK STOCK, • . . . . . . 200

Morrill StOCK, . . . . . . . . . 2 IO

HAMPTON StOCK, • . • . • . . . 226

PATChen STOCk, . . . . . . . . $23 \mathrm{I}$

Cadmus Stock, . . . . . . . . . 235

ANNFIELd STOCK, • • • . • . • . . 237

Fearnaught Stock, . . . • • • . 239

Hambletonian STOCK, . • . • . . . 246

Miscellaneous, . . . . . . . . . 254

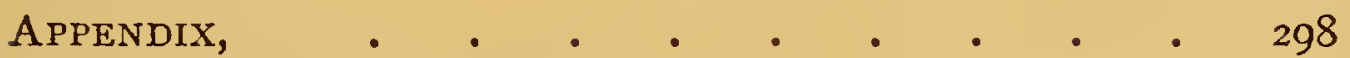

Extract From PUblic IAWS, . . . . . . 318

INDEX, • • • • • • • • • • 3Ig 



\title{
I LLUSTRATIONS.
}

\author{
PAINTED BY ENGRAVED BY \\ King William. - G. H. Bailey. - J. A. J. Wilcox. \\ Palmer Knox. - G. H. Bailey. Russell \& Richardson. \\ General Knox. • • • • • • • See page I23.
}





\section{INTRODUCTION.}

The following work, which is intended to be both a stud book and trotting register of Maine-bred horses, was undertaken through a strong desire to trace out and preserve in a form convenient for reference, the pedigrees and performances of those noted animals whose names and achievements adorn the brightest pages of the turf history of our country.

In presenting it to the public, I do so with the full understanding that trotting pedigrees are very unreliable, and, although I have endeavored, as far as possible, to establish the breeding of every animal, there are so many ways in which errors may creep in, that I should not dare to assert that they are, in all cases, absolutely correct. Neither would I assert that the list is complete and satisfactory in every respect, only that it is as nearly so as I am able to command.

If any one has knowledge of any errors or cmissions, I will esteem it a favor to be informed of the fact, and should another edition be issued, the proper corrections will be made. I can only say that I have earnestly sought after the truth, with nothing added and nothing taken away.

In 1852, an eminent writer-Sanford Howard, Esq., of Boston-made the following remark: "Maine has, until within a few years, furnished nearly all the trotting stock, of any note, in the country."

That Maine horses have not deteriorated, and that a large proportion of the best trotting and gentlemen's driving horses in the country are still bred in Maine, is fully attested, 
for the turf records of the country are full of their names and achievements; and the peculiar excellences of form and carriage of the "Drew," the "Eaton," the "Knox," and other strains of blood, are quite as well known, and as spiritedly championed, by their respective admirers, in the marts, and at the racing courses of Boston and New York, as on the breeding farms and stables in Maine.

I have thought it might be interesting to give an account of the rise and progress of the sport of trotting, from the commencement until the present time, showing the prominent part taken from time to time by Maine bred horses:

"The first time," I quote from Frank Forrester's "Horse of America," "ever a horse trotted in public for a stake was in 1818 , and that was against. time for $\$ 1,000$. The match was proposed at a jockey club dinner, where trotting had come under discussion, and the bet was that no horse could be produced which could trot a mile in three minutes. It was accepted, and the horse named at the post was 'Boston Blue,' who won cleverly, and gained great renown."

In 1819 Zuarrow, a chestnut gelding, was taken from Maine to Massachusetts by O. B. Palmer, of Waterville, and trotted a mile, "just across Charleston Bridge," in 2.57.

The year 1825 brings us to what may be called the origin of authorized trotting, as in it was established the New York Club, got up with a view of improving the speed of road horses, "by which means many horses whose speed was then in obscurity, might be brought into notice, and consequently their value enhanced."

The first meeting was given "at the Club's course, near the Jamaica Turnpike, Long Island," in May, 1826. The editor of the American Farmer, after publishing the notice of the above meeting, adds the following exhortation: "Why are not clubs like the above formed in this vicinity? It would afford an excellent test for the speed and value of harness horses, as the turf does for the race horse. Who will set it a-going ?" 
In 1835, the sport of trotting became more and more popular, and there was scarcely a gentleman in New York who did not own one or two fast horses, and matches were daily ridden or driven. In 1836, Fanny Pullen (see page 39) trotted in a race over the Centreville Course, against Dutchman and Confidence. The race was two-mile heats, in harness, and the betting ran very high. The Eastern men backed Fanny Pullen, the Philadelphians put up strongly on Confidence, while the New Yorkers stuck to Dutchman, who won in two

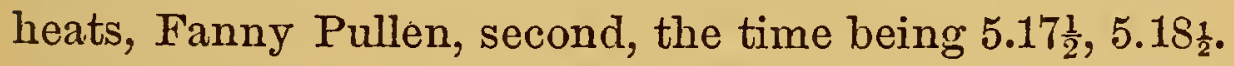

In 1837, Daniel D. Tompkins (see page 38 ) beat Rattler, over the Centreville Course, three-mile heats, in 7.59, 8.09 , which was the fastest as yet recorded.

In 1838, Daniel D. Tompkins won a race of three-mile heats, over the Hunting Park Course, Philadelphia, beating Edwin Forrest; first heat, 8.07, second heat, Forrest distanced, first two miles done in 5.30. This was a match for $\$ 10,000$, and after winning it Tompkins challenged any horse in the world to trot him three-mile heats, over the Hunting Park Course, for the sum of $\$ 1000$, without finding a taker.

From the time Boston Blue "gained great renown," by trotting a mile inside three minutes, we find continual advancement.

Trotting time stood for years at 2.32, then 2.30, until, in 1849 , Pelham (see page 278 ) "rose into high notice," by trotting a mile in the unprecedented time of 2.28 , in harness, in a race against Lady Suffolk and Jack Rossiter.

Mac (see page 53) also went extremely well this year, winning eight times, against such nags as Lady Moscow, twice, Lady Suffolk, four times, Jack Rossiter, twice, Moscow, Gray Eagle and Zachary Taylor. He made his mile, once, in 2.26, and his two miles in 5.09, 5.10.

This year was enough to prove him what he was, a first-rate animal for his day.

Cotemporary with the above were the following named 
horses, who were all nore or less distinguished for their performances on the turf: Zachary Taylor, Independence, Henry, Tom Benton, Blanc Negre, Ice Pony, Lafayette, Lady Swan Dying Sergeant, Sorrel Hiram, etc., all of which were bred in this State.

In 1856, Flora Temple cut the record down to $2.24 \frac{1}{2}$, in a race in harness, against Taconey, under saddle, in which she distanced him in the first heat, in what Frank Forrester terms the prodigious time of $2.24 \frac{1}{2}$. Here the record stood until 1859 , when she won a race against Princess, over the Eclipse Course, L. I., in which the previous time was not only beaten by two seconds and a half, but it was beaten in all the heats. Mr. Woodruff says, "there had never been anything like such a trot before." Flora won in three straight heats, in $2.23 \frac{1}{2}$, $2.22,2.23 \frac{1}{2}$.

The following September, at Cincinnati, Flora beat Iko Cook in straight heats, the last of them being trotted in $2.21 \frac{1}{2}$. Oct. 15, same year, at Kalamazoo, Mich., she won a race in three heats, beating a horse called Honest Anse and Princess, and capped the climax of her fame by winning the third heat in the remarkable time of $2.19 \frac{3}{4}$. Since which the following named horses have made a record of 2.20 or better, viz.: Goldsmith Maid, American Girl, Lucy, Dexter, George Palmer, Lady Thorn, Judge Fullerton, and Occident.

With the increase of speed there has also been a proportionate increase in the number of animals engaged, and in the number of public contests recorded. In 1856 there were eleven heats trotted in 2.30, or less, while in 1871, there were three hundred and eighteen. The whole number of public contests recorded in 1871 was 1,665 , representing over a million of dollars in premiums and purses, besides the great value of the horses. The horses would average $\$ 1000$ each, and not less than three to each race, which would be, say, $\$ 5,000,000$ in horses, alone who actually trotted in the several races during that year. From this, and other reliable 
data, I calculate the value of those in training, and in the breeding studs, all united, would amount to not less than $\$ 15,000,000$, being that sum invested in this country in trotting and pacing horses alone.

In 1872, Maine horses did extremely well. August 8, at Buffalo, N. Y., Lady Maud, by Gen. Knox, (see page 127) won a race for five-year-olds, beating Zilcaadi, Mary H. Rowe's

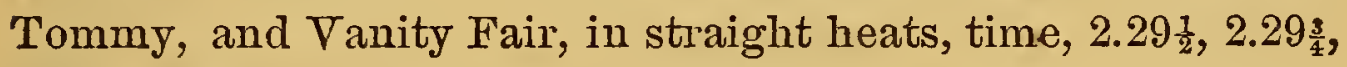
2.27! . Oct. 10, at Prospect Park, she won a matched race, for a purse of $\$ 5000$, beating Lucille Golddust, winning the first heat in $2.30 \frac{1}{2}$, the third in $2.22 \frac{1}{2}$, and the fourth and race in $2.22 \frac{1}{4}$, which is the fastest on record for the age.

Sept. 14, at Mystic Park, Boston, Camors, by Gen. Knox, (see page 126) beat Crown Prince, Sleepy John, Nonesuch, and Dauntless, time, $2.23 \frac{3}{4}, 2.24 \frac{1}{2}, 2.25$.

Sept. 19, he beat William H. Allen, Judge Fullerton, Lula and Triumph, at Prospect Park. The time of the first heat was 2.23 , and the second $2.21 \frac{3}{4}$. The third heat was won by W. H. Allen, in 2.24, and the fourth by Camors in 2.231, making four heats, all under 2.25 .

Oct. 21, Ben. Morrill (see page 212) won a four-year-old race, at Prospect Park, beating Rowe's Tommy, and Dixon. Rowe's Tommy won the first heat, in 2.48 $\frac{1}{4}$, and Ben. Morrill the second, in $2.34 \frac{1}{2}$, the third in the remarkably fast time of $2.32 \frac{3}{4}$, and the fourth heat and race in 2.36 .

Mr. Linsley, in his work on Morgan horses, published in 1860 , in speaking of the average speed of trotting horses' says, "To enable us to form some idea of the average speed of the trotting horses of the country, we made a summary of all the time, at mile heats, reported in the Spirit of the Times for the year 1852, and the average time made by winning horses, at mile heats, during that year, was 2.50, and a small fraction." From this it is plain that a horse which could trot a mile within 2.50 would, in 1852 , have been able to defeat a large majority of the trotting horses of the country. 
In 1873 , there were recorded 2,512 public contests with 475 heats in 2.30 or less, and expecting to find the average time much reduced, I made a summary of all trotting races in har-

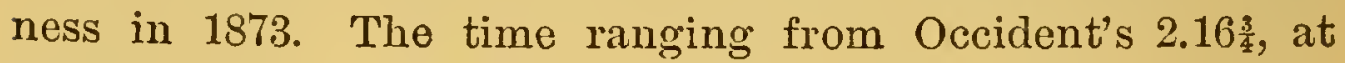
Sacramento, in Sept., to, and including all those in which the winning horse obtained a record of 3.00 , or better, and casting out all performances made to wagon, by pacers, colts four years old, or under, double teams, and by horses where the winning horse did not make a record of 3.00 , or better, I find the number of races to be 182:3, and the average time 2.41 and a fraction.

Since Pelham "rose into high notice" in 1849, by trotting a mile in the then unprecedented time of 2.28 , in harness, up to the close of the trotting season of 1873 , a record of 2.30 , or better, has been made by the following-named Maine horses. In the body of this work will be found full and minute descriptions of each, giving all that is known of their pedigree, where, and by whom bred, and their most noted performances on the turf. Below I give simply the names in alphabetical order, fastest record up to the close of the season of 1873, and date and place of performance:

$\begin{array}{lrlr}\text { Baby Boy, } & 2.30, & \text { Mystic Park, Boston, } & \text { Sept. 3, } 1873 \\ \text { Baruey Kelley, } & 2.26 \frac{1}{4}, & \text { Buffalo, N. Y., } & \text { Aug. 5, } 1873 \\ \text { Bay Whalebone, } & 2.26 \frac{1}{4}, & \text { Mystic Park, Boston, } & \text { June 28, } 1871 \\ \text { Belle of Portland, } & 2.26, & \text { New City Course, N. Y., } & \text { Oct. 10, 1861 } \\ \text { Belle Strickland, } & 2.26, & \text { Narragansett, R. I., } & \text { Oct. 4, 1870 } \\ \text { Blackstone Belle, } & 2.28 \frac{1}{2}, & \text { Riverside Park, Boston, } & \text { July 2, 1866 } \\ \text { Camors, } & 2.20 \frac{1}{2}, & \text { Buffalo, N. Y., } & \text { Aug. 16, } 1873 \\ \text { Emperor, } & 2.30, & \text { Narragansett, R. I., } & \text { Oct. 14, } 1868 \\ \text { Fleetwood, } & 2.29, & \text { Troy, N. Y., } & \text { Sept. 7, } 1871 \\ \text { Gen. McClellan, } & 2.26, & \text { Belfast, Me., } & \text { Sept. 24, } 1864 \\ \text { Geo. B. McClellan (now } & & & \\ \quad & & \text { Sirigo), } \\ \text { Gilbreth Knox, } & 2.29, & \text { Belfast, Me., } & \text { Oct. 7, } 1869 \\ \text { Independence, } & 2.26 \frac{3}{4}, & \text { Narragansett, R. I., } & \text { July 4, } 1843 \\ \text { Lady Maud, } & 2.28, & \text { Beacon Course, N. J., } & \text { Oct. 10, } 1872 \\ \text { Lew Pettee, } & 2.22 \frac{1}{4}, & \text { Prospect Park. L. I., } & \text { June 29, } 1868\end{array}$


License,

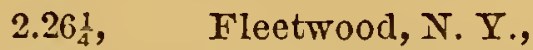

Sept. 22, 1870

Little Fred,

$2.26_{4}^{3}$,

Prospect Park, L. I.,

May 29, 1869

Mac,

2.27 ,

Cambridge Course, Mass., June 14, 1849

Madawaska Maid,

$2.29 \frac{1}{2}$

Mystic Park, Boston,

Oct. 6,1868

Nabocklish,

$2.29 \frac{1}{4}$

Cincinnati, Ohio,

Aug. 16, 1864

Pelham,

2.28

Centreville, N. Y.,

July 2, 1849

Shepard Knapp, Jr.,

$2.29 \frac{1}{2}$

Mystic Park, Boston,

June 7, 1869

St. Elmo,

$2.29 \frac{1}{4}$

Mystic Park, Boston,

June 21, 1872

Stranger,

2.30

Bangor, Me.,

July 4, 1855

Timmany,

\subsection{7}

Bangor, Me.,

$\longrightarrow, 1871$

Uncle Abe (now Glen-

$\begin{array}{crlr}\text { gary), } & 2.27, & \text { Buffalo, N. Y., } & \text { Aug. 10, 1871 } \\ \text { Wm. H. Taylor, } & 2.29 \frac{1}{4}, & \text { Nalragansett, R. I., } & \text { Oct. 14, 1868 } \\ \text { Winthrop Irorrill, Jr., } & 2.28 \frac{3}{4}, & \text { Prospect Park, L. I., } & \text { Sept. 25, 1873 } \\ \text { Zac. Taylor, } & 2.29, & \text { Philadelphia, } & \text { Oct. 18, 1852 }\end{array}$

This list of Maine 2.30 horses I believe to be complete, with perhaps the following exceptions: I am informed, since the body of the work has been in the printer's hands, that the gray gelding, Hopeful, by Godfrey's Geo. M. Patchen, which won a race at Prospect Park, Sept. 23, 1873, in a field of twelve horses, winning the last three out of five heats, in 2.26 , 2.27, 2.25, was bred in Maine, near Newport, and kept there until four years old. I am also informed that Elisha (which see) won a record of 2.26 in California, and although I am unable to find any published account of said race, still I am inclined to place confidence in the statement.

Shepard F. Knapp, the one that went to England, won a race near Paris, France, trotting two and a half miles in six minutes and fourteen seconds, which is a trifle better than 2.30 to the mile. Many believe that Plato, by Gen. Knox, has a record of $2.27 \frac{1}{2}$, and since my list of 2.30 horses appeared in the Maine Farmer I have received several letters, asking my reasons for not including Plato. To all such $I$ will say that $I$ am unable to find any such record to his credit. I have been informed, also, that Ben. McClellan, who won the second heat in a race, at Troy, $\mathrm{N}$. Y., July 24, 1867, in 2.30, was bred in Maine, and got by the Old Drew horse, but I have failed entirely to identify him. 
Of the above number the following, viz.: Baby Boy, Barney Kelley, and Winthrop Morrill, Jr., were wholly unknown, or at best had only a local reputation at the commencement of the trotting season of 1873 , and I should not be surprised if the season of 1874 found the following Maine-bred horses performing in the "twenties," viz.: the stallions King William and Ben. Morrill, the former having thus early in the season scored a record of $2.31 \frac{1}{4}$ in harness, and 2.35 to wagon, while the latter has trotted close to ' 30 ; and the black gelding, James G. Blaine, claimed by his owners to be the fastest green horse in New England, besides many others, whose names may not even appear in the following pages.

The date of the introduction into the State of Winthrop Messenger, Gen. Knox, Winthrop Morrill, Tom Patchen, and others of less note is given, in its appropriate place, in the body of the work, and I will not allude to it here.

It has been estimated that there are from twenty to thirty thousand mares used for breeding purposes in Maine, and doubtless in the near future the breeding of gentlemen's driving horses and trotters, will become one of the most profitable sources of wealth in the State, the natural productive capacity of which is almost without limit.

The complete list of stallions standing for service in the State in 1873, as taken from the Registry of Deeds in the several counties, will be found in the following pages, those bred in Maine classed with the families to which they belong, and those not Maine bred in an appendix.

The complete list of names, claimed through the Maine Farmer, is also included, by special permission.

Taking this work as a foundation, and making use of the generous offer of the Farmer to allow names to be claimed through its columns, free of charge, the task of the future compiler may be rendered a comparatively light one.

The engravings of King William and Palmer Knox were made expressly for this work, from paintings from life, exe- 
cuted by Mr. Bailey, of Portland, the well-known artist, and are excellent likenesses of the animals they represent. For the cut of Gen. Knox, I am indebted to the kindness of Mr. T. S. Lang, his former owner.

I have lately received information which leads me to think that the pedigree of Barney Kelley, as given on page 218, is very doubtful, to say the least, also, that recent investigations have shown that the dam of King William (see page 226) was not by Witherell, but by Arabian Hunter, he by Sir Charles, etc. Among those known to be Maine-bred, about which we have but little information, are Roden's Penobscot, who trotted in $2.31 \frac{1}{2}$ in 1873 , Ticonic, who performed many races in the "thirties," Taylor's Little Fred, the gelding Daylight, ètc., etc.

It will be seen by a careful perusal of the following pages that I am quite largely indebted to Wallace's American Trotting Register, a work, by the way, that should be in the hands of every intelligent breeder and horseman. I believe, however, the proper credit has been given in every instance.

In conclusion, I desire to express my gratitude to all those who have aided me in the compilation of this work, by the valuable information and words of encouragement which they have so generou sly bestowed.

HARTFORD, ME。

J. W. THOMPSON. 



\title{
NOTED MAINE BRED HORSES;
}

\author{
THEIR ANCESTORS AND DESCENDANTS.
}

\section{MESSENGER STOCK.}

\section{WINTHROP MESSENGER.}

Chief among the distinguished horses known in this State was the "Old Winthrop," or Maine Messenger. He was purchased in Paris, Oneida Co., New York, by Alvin Hayward, of Winthrop, Mie., and brought by him into that town in the year 1816.

Those who have seen him describe him as a "large, gray, muscular horse, in his old age white as chalk, with a clumsy head, but well proportioned body and legs; nearly 17 hands high, and weighing in ordinary flesh 1,300 pounds." His form and general appearance indicated a powerful animal, and he possessed a strong dash of temper, but he never exhibited any of those qualities which would have entitled him to be called "a fast horse."

He was got by Imported Messenger, a gray stallion $15 \frac{3}{4}$ hands high, and stoutly built, who was landed from a vessel at the foot of Market street, Philadelphia, in May, 1788. His dam's pedigree is lost, and is at present un- 
known. Imported Messenger was foaled in 1780, bred by John Pratt, Esq., of New Market, England, where he was a successful runner, winning the King's Plate in 1785, when five years old. His pedigree was as follows: Got by Mambrino, dam by Turf, grand dam by Regulus, etc. It is said that " the other horses which accompanied him on the voyage to this country had become so reduced and weak, that when taken off the ship which brought them, they had to be helped and supported down the gang-plank; but when it came Messenger's turn to land, he with a loud neigh, charged down, with a colored groom on each side holding him back, and dashed off up the street on a stiff trot, carrying the grooms along in spite of all their efforts to bring him to a stand still. He died January 28, 1808.

Winthrop Messenger was the first messenger horse brought into Maine, and was owned several years in Winthrop and vicinity by different parties. First by $\mathrm{Mr}$. Hayward, then Geo. W. Stanley, and A. M. Shaw. In $1829 \mathrm{Mr}$. Shaw sold him to John M. Eustis, of Dixfield, Oxford Co., for $\$ 180$.

While owned in.Dixfield he stood for service at $\$ 5.00$, but having so little patronage he was turned out to pasture, when he broke his near fore leg. This, however, did not incapacitate him for service in the stud, although he was lame ever after. Eustis sold him back to Sliaw in 1832, and he was afterwards taken to Anson by Henly Stone, and died there in 1834. He was, says Mr. Woodruff, of great value to Maine, and got many fine trotters.

Mr. J. H. Wallace says, "he founded a race of trotters that have no superiors in the Union. From his loins have sprung a race that all the world recognizes as among the fastest and best that this country has ever produced." 


\section{BUSH MESSENGER.}

Dapple gray stallion, 16 hands high, and weighed 1,300 pounds; foaled in 1833, bred by William Bradbury, of Byron, Me., got by Winthrop Messenger, while the latter was owned by John M. Eustis of Dixfield. His dam was a medium size black mare, whose pedigree was unknown. Mr. Bradbury let Benjamin Palmer of Readfield have him and he was afterwards known as the Palmer Horse.

He had his thigh broken by a kick, which caused his death in 1840, when only seven years old. It is said that Mr. Bradbury was taking his mare to a Morgan horse then owned by Spaulding Smith, of Wilton, that she became lame, and he being unable to proceed farther than Dixfield, was induced, against his wishes, to have her served by Winthrop Messenger; the produce was Bush Messenger.

\section{QUIMBY MESSENGER.}

Gray stallion, 16 hands high, and weighed about 1,200 pounds; foaled in 1830, bred by John Quimby of Greene, got by Winthrop Messenger, dam a bay mare (called the Mower mare), pedigree unknown. He was considered a fine horse, and never passed out of Mr. Quimby's hands. He died in 1837, of horse ail.

\section{HUNTON HORSE.}

Gray stallion, in his old age white as chalk, 16 hands high, and weighed 1,100 pounds; foaled in 1840, bred by the widow Lane, of Readfield, Me., got by Bush Messenger, dam a large white mare, pedigree unknown. Peter Fifield bought him when two years old, and sold him when three, to Wellington Hunton, of. Wayne. He was afterwards purchased by America Farrar of Buckfield, 
and died there in 1857. He was a horse of fine style, could trot in three minutes, and was noted for getting good roadsters.

\section{JOHN B. DUNTON.}

Dark, stone gray stallion, foaled in 1853, bred by Hiram Reed of Augusta, Me., got by Bush Messenger, 2d; dam by the Guild Horse. Mr. Reed had him gelded and sold him to parties in Boston.

\section{WITHERELL HORSE.}

Sorrel stallion, with light mane and tail, with white in the face, and white hairs mixed in all over his body, $1 \tilde{o}_{\frac{1}{2}}^{\frac{1}{2}}$ hands high, and weighed from 1,050 to 1,100 pounds. Foaled in June, 1834, bred by Rev. Samuel B. Witherell, Norridgewock, Me., got by Winthrop Messenger, dam, a light sorrel mare raised and owned by $\mathrm{Mr}$. Witherell, and said to be of Morgan descent.

In 1844 he was sold, and was owned successively by Mr. Russell, of Skowhegan, Joshua Young, of Mercer, Alden Hilton, of New Sharon, and Richard Fassett, of West Mills, Industry, wheire he died in 1859. He was a kind animal in the harness, but was often vicious and hard to manage when out. He was a good and fast roadster, but laid no claims to being a "fast horse." His colts were much souglt by horsemen from out of the State. Perhaps we ought in justice to state that there are persons who positively assert that Witherell was got by Dolphin (which see).

\section{LION.}

Sorrel gelding, 16 hands high, and weighed 1,100 pounds, foaled in 1822, bred by Rev. Samuel B. Witherell, 
of Norridgewock, Me., got by Winthrop Messenger, dam, the old Witherell mare (so called), to distinguish her from Witherell's dam which was known as the young Witherell mare. In 1829 or' $30 \mathrm{Mr}$. Witherell sold him to Benjamin Hodges, of Hallowell, and he to Reuben Davis, of Boston. He was a horse of the finest style and carriage, and was at that time the fastest horse in Boston or vicinity. This was before there were any trotting parks in the vicinity of Boston, and they used to trot him on the road. He would have been very fast if he could have been properly trained. In 1834 Mr. Davis' stable on Endicott street was burned, and Lion was saved by knocking a hole through the side of the stable and taking him out on the Salem street side. Mr. Davis afterward took him to Windsor, N.H., and he finally went to Baltimore, Md.

\section{STATE OF MAINE.}

Gray stallion, 16 hands high, and weighed 1,185 pounds, foaled in 1844, bred by Mr. Berry, of Wayne, got by the Stone horse; dam by Winthrop Messenger; Berry sold him to Mr. Foss, of Wayne, he to a Mr. Foss, of Scarborough, and he to James Jack, of Portland. Mr. Jack sold him to Fred. Johnson, of New York. Oct. 26, 1856, at Rochester, he won a race in three straight heats, beating Harkaway. July 3, 185s, at Batavia, N. Y., he beat Old Tom and Ripton, mile and repeat, in 2.44-2.40. He was sold to James T. Fulton, of Lewiston, N. Y., in 1851, and stood there several years; here he sired the horse afterward known as Dr. Logan's Messenger. This horse (Logan's Messenger) is the sire of Crown Prince, record 2.25. State of Maine died in 1865 or 1866. 


\section{ALLEN HORSE.}

Sometimes called Norridgewock Messenger; gray stallion, 16 hands high, and weighed 1,200 pounds; foaled in 1844, bred by James Moulton, of Wayne, got by the Hunton horse; dam pedigree unknown. Moulton sold him to Daniel Foss, of Wayne, and he was known in Wayne and vicinity as the Foss horse.

Foss sold him to Lewis Allen, of Norridgewock. He afterwards went to Springfield, Mass.

\section{MESSENGER BONUS.}

Gray stallion, 15 hands high, foaled in 1845 , bred by Levi Dow, of Waterville, Me., got by the Stone horse, dam by Bonus; a roan stallion brought to Maine from Canada.

Henry Lawrence, of Fairfield Centre, bought him when four months old, and owned him until he was about twelve years of age, when he had him gelded, and he was taken to Boston.

\section{SHORES MESSENGER.}

Dapple gray stallion, $15 \frac{1}{2}$ hands high, foaled about 1845 , bred by George Shores, of Waterville, got by the Stone horse; dam the Shores mare (so called). Shores sold him to Esau Savage when six years old, and he sold him to a circus company, and he went out of the State.

\section{STONE HORSE.}

Gray stallion, foaled in 1828, bred by F. Ballard, of Augusta, Me., got by Winthrop Messenger, dam, an English mare; brought to Maine from the Province of $\mathrm{New}$ Brunswick. Ballard sold him to Henry Stone, of Anson. Stone kept him several years, and then sold him to Tufton 
Simpson, of Winslow. He was first known as the Stone, and then as the Simpson horse.

\section{KENNEBEC MESSENGER (BIAATE'S).}

Dapple gray stallion, foaled in 1846 , bred by Lewis $\mathrm{H}$. Blake, of Mt. Vernon, Me., got by Bush Messenger, $2 d$, ån, a sorrel English mare. Blake sold him when five years old to Geo. M. Robinson, of Augusta. Mr. Robinson kept him two years, and took him to the First National Horse Fair, at Springfield, Mass., where he sold him to parties in Baltimore, Md. From thence he was taken to New Orleans, La., where he trotted in the thirties.

\section{HICKORY.}

Gray stallion, foaled in 182-, bred by Geo. W. Stanley, of Winthrop, Me., got by Winthrop Messenger; dam, a fine "Buckskin " mare, known as the Wing mare. "Stanley owned lim in 1834, and lis speed for trotting was much talked alout." We have no knowledge of his subsequent history.

\section{BUSH MESSENGER, 3D.}

Gray stallion, foaled in 1858, bred by William Rollins, Pittston, Me., got by Busl Messenger, 2d; the last of his get before going west; dam, a mare brought from the Province of New Brunswick. He was afterwards gelded, and is now kept in a livery stable in Augusta, Me., as a let horse.

\section{LEAVITT HORSE.}

Dapple gray stallion, 15 hands high, and weighed about 1000 pounds, foaled in 1836, bred by Howard Sylvester, of Greene, Me, got by Quimby Messenger. Dam, a gray mare, weighing about 850 pounds, a noted 
roadster, got by Quicksilver. Sylvester sold him, when eight years old, to Mr. Leavitt, of North Turner Bridge, for $\$ 100$. Mr. Leavitt sold him, when eighteen years old, to Frank Howard, of Leeds, for $\$ 140$, and he took him to Bridgewater, Mass. He was a great roadster.

\section{FARMER'S MESSENGER.}

Dapple gray stallion, with very heavy black mane and tail, 17 hands high, and weighed 1300 pounds, foaled in 1845, bred by C. P. Ford, East Livermore, Me., got by Hunton Horse. Dam, a large sorrel mare, with white in face, of Morgan descent. Ford sold him in March, 1852, to H. W. Humphrey, of 'Turner, and he kept him until he died; in Nov., 1853. He was a great roadster, and was a fine type of the Messenger stock.

\section{ROYAL OAK.}

Blood bay stallion, with black points, $15_{\frac{1}{2}}^{\frac{1}{2}}$ hands high, foaled about 1838, bred by Jabez Merrill, of Turner, Me., got by Quimby Messenger. Dam, a mare of Morgan descent. Merrill sold him, when about six years old, to Geo. M. Robinson, of Augusta. Mr. Robinson afterwards sold him to America Farrar, of Buckfield, and he to Charles Proctor, of Corinna. He died in Dover, N. H., in June, 1852.

\section{PISHON IIORSE.}

Gray stallion, $15 \frac{1}{2}$ hands high, foaled in 1845 , bred by Tufton Simpson, of Winslow, Me., got by the Stone Horse, dam said to be by Quicksilver. He passed into the hands of Mr. Pishon, of Pishon's Ferry, nine miles above Waterville, while young, and became known as the Pishon Horse. He was said to be very fast, and after be- 
ing used quite extensively in the stud, he was finally emasculated and taken to Boston.

\section{MERROW HORSE.}

Dark bay stallion with black points, of compact build, coaled about 1849, bred by Mr. Hight, of Athens, Me., got by Witherell, dam, of Morgan descent. Mr. Hight sold him to Harford Merrow, of Hartland, and he became known as the Merrow Horse. He is said to have trotted a mile on the Skowhegan track in 2.44. He is the sire of the famous mare, Belle Strickland.

\section{KENNEBEC.}

Sorrel, or chestnut, stallion, with light mane and tail, about $15 \frac{1}{2}$ hands high, foaled in 1849 , bred by $\mathrm{Mr}$. Weston, of Skowhegan, Me., got by Witherell, dam. by Quicksilver. S. S. Parker, of Waterville, bought him when three years old, and sold him to J.F. Phillips, and he was afterwards taken to Ohio, and owned by L. Pelton, of Warren. He afterwards went to Janesville, Wisconsin.

\section{BUSH MESSENGER, 2D.}

Dapple gray stallion, 16 hands high, and weighed 1,200 pounds, foaled in 1840 , bred by Francis Perley, of Winthrop, Me., got by Bush Messenger; dam, a French mare from Canada. Perley sold him when five years old to M. H. Delano of Camden, who kept him three years and then sold him to his brother, Ira L. Delano, of Canton. He sold him two years afterward to Hiram Reed and Allen Lambard, of Augusta. He was kept in Augusta five years and then put up in a lottery and drawn by William Rollins, of Pittston. Rollins owned him two years and sold him in 
1857 to William H. Ladd, of Ohio; who sold him to Gen. John S. Goe, of Brownville, Pa., in 1858.

He was afterward sold to parties in Northern Ohio and died there in 1362. He was the sire of Alice Gray.

\section{HOMAN HORSE.}

Gray stallion, foaled about 1835, bred by John Homan, of Vassalboro', Me., got by Stone Horse; dam by Exton Eclipse. Exton Eclipse by American Eclipse, dam by Imported Exton. Exton Eclipse was owned for a time in Maine, but was afterwards taken to New York, and is the sire of the grand dam of Jay Gould. Homan sold him to Joseph Freeman, of Waterville, who gelded him and sold him to Samuel Johnson of Hallowell, and he was afterwards taken to Boston. He was a very powerful horse, and his road'gait was fifteen miles an hour.

\section{GRAY EAGLE.}

Gray stallion, 16 hands high, and weighed1, 110 pounds; foaled in 1850. bred by Robert Gould, of Leeds, got by the IIunton horse; dam of Messenger descent.

Mr. Gould sold him to Mr. Leadbetter, of Leeds, and he to Irving Robinson, of sumner. He kept him several years, until 1860, when he was carried to Massachusetts.

\section{TRUSTEE MESSENGER.}

Gray stallion, 16 hands high, and weighed 1,300 pounds, foaled in 1846, bred by M. H. Delano, of Camden, Me., got by Bush Messenger, 2d; dam, a mare brought from the province of New Brunswick. Mr. Delano, sold him in 1850 to his brother, Ira L. Delano, of Canton, who sold him in 1852 to Gideon Ellis, jr., of Canton. . He sold him 
in 1854 to Charles Learitt, of Livermore, and Leavitt took him to Ohio, and afterwards to Michigan.

\section{CALVIN.}

Sorrel stallion, $15 \frac{1}{2}$ hands high, and weighed 1,150 pounds, foaled in 1846, bred by M.H. Delano of Camden, Me., got by Bush Messenger, 2d; dam by Fox, a sorrel stallion formerly owned by Thomas Daggett, of Hope, Me.; his pedigree we do not know. Mr. Delano sold Calvin in 1852 to a stock company, in the vicinity of Searsmont, and we have no knowledge of his subsequent history.

\section{HONEST BEN.}

Sorrel stallion, 16 hands high, and weighed about 1,400 pounds, foaled in 1847, bred by M. H. Delano, of Camden, Me., got by Bush Messenger, 2d; dam of English blood. Mr. Delano sold him to Nathan Holbrook \& Co., Neponset, Mass. He was afterwards called Daniel Webster. He could trot better than 2.40 .

\section{MOODY'S MESSENGER.}

Dapple.gray stallion, 16 hands high, and weighed 1,300 pounds, foaled in 1846, bred by Jonathan Moody, Lincolnville, Me., got by Bush Messenger, 2d; dam by Fox.

Mr. Moody sold him to Obadiah Wood, of Barre, Vt. He could trot in 2.45 and was a powerful horse.

\section{CALL HORSE.}

Dark brown stallion, with black points, and no white marks, height, $15 \frac{1}{2}$ hands, and weighed about 975 pounds, foaled in 185, bred by Mr. Robinson, of Hartland, Me., got by the Merrow Horse, dam, the Lord mare, by Tele- 
graph, he by Witherell. He was afterwards sold to $\mathrm{Mr}$. Call, of Dresden, Me., and was known as the "Call Horse."

\section{WOODBROOK MESSENGER.}

Dapple gray stallion, 16 hands high, weighs 1,180 pounds, foaled in 1861, owned by R. B. Esty, Houlton, Me., got by Jehu, he by Warrior, he by Young Winthrop Messenger, by Winthrop Messenger. Dam of Woodbrook Messenger by an imported English horse, grand dam by an English hunter. For pedigree of Jehu, see Wallace Trotting Register, vol. ii. page 254.

\section{FLYING MAC.}

Dapple gray stallion, $15 \frac{1}{2}$ hands high, foaled in 1859 , bred by Isaac Mancy, of Augusta, Me., got by a son of Bush Messenger, 2d. Dam, a dapple gray pacing mare, bought in Canton, of Daniel Foster, by George M. Robinson, and sired by Mac (which see). Flying Mac was sold to John Shaw, of Augusta, when four months old, and was afterwards taken to Boston.

\section{KING HEROD.}

Iron gray stallion, about 17 hands high, foaled in 1848, bred by James Ford, East Livermore, Me., got by the Hunton horse; dam, not traced. Ford sold him, when four months old, to Elihu Lawrence, of Fairfield. He sold him, when four years old, to Nahum Tozier, also of Fairfield. He was finally taken to Aroostook county.

\section{LION MESSENGER.}

Gray stallion, foaled in 1839, bred by Obadiah Holt, Clinton, Me., got by the Stone horse, dam, by Rocking- 
ham, a running horse, brought to Me. from N. H. Holt sold him when young to Jeremiah Wardwell, and he to Gideon Wells, also of Clinton, in 1841. He was afterwards owned by Jacob Nutting, Detroit; Richard Berry, Leeds ; E. G. Thompson, Dover ; R. Baker, Carmel, and Joseph Clement, of Detroit, in whose hands he died.

\section{YOUNG WINTHROP MESSENGER.}

Sometimes called Shaw Horse and White Warrior, gray stallion foaled in 182-, bred in Winthrop, Me., got by Winthrop Messenger; dam, not traced. He was sold when a coit and taken to Woodstock, New Brunswick, by a Mr. Shaw.

\section{YOUNG SUFFOLK.}

Formerly called Waterville. Gray stallion, foaled in 185-, bred by Henry Wing, Fairfield, Me., got by Pishon horse, dam, a fast pacing mare, by a son of Stone horse. Wing sold him, when a sucking colt, to Ash Savage, of Waterville, and he to Oliver Walton, of Boston, when three years old. Walton sold him to James Irving, of New York, and he to Geo. Raymond, of Long Island.

\section{BLANC NEGRE.}

Red roan gelding, 15 hands high, foaled in 183-, bred by Henry Lawrence, of Fairfield, got by the Lawrence horse, he by Stone horse, dam by Quicksilver. He was sold to Tufton Simpson, of Winslow, and by him to Oliver Walton, of Boston. He was afterwards taken to Philadelphia, and owned by Andrew Banner, and afterwards by C. P. Reif. He was very fast, and trotted some in double team with Daniel D. Tompkins. 


\section{DANIEL D. TOMPKINS.}

Dark sorrel, or chestnut gelding, with white stripe in face and white hind feet, about 15 hands high, foaled in 1830 , bred by a Mr. Libby, of Farmington, Me., got by Winthrop Messenger. Dam, a roan mare, brought from Westbrook by Mr. Libby; her pedigree was unknown, but her appearance indicated good breeding. Mr. Libby sold the colt, when one year old, to Mr. Gleason, and he to Jonathan Perkins, also of Farmington.

In March, 1834, Perkins sold him to Charles Simonds, of Malden, Mass., for \$125. Simonds sold him to a butcher in Charlestown, where Mr. Oliver Walton saw him and bought him and took him to New York. In 1837, Oct. 5, over the Centreville course, he beat Rattler, under the saddle, three-mile heats, in 7.59-8.09, which was the greatest time as yet recorded. In May, 1838, on the Hunting Park Course, Philadelphia, he trotted a race of three-mile heats against Ned Forrest, for $\$ 5000$ a side, to go as they pleased. Daniel $D$. won the first heat in such style that Gen. Cadwallader, who owned Ned Forrest, sold out his chance in the race for $\$ 500$. Anderson and Spicer, of New York, bought it, and put Forrest in harness, but Daniel $\mathrm{D}$. won it without any trouble. Time of first heat, S.07; second heat, Forrest distanced, first two two miles done in 5.30.

After winning the race, Tompkins challenged any horse in the world to trot him three-mile heats, over the Hunting Park Course, at Philadelphia, for the sum of $\$ 1,000$, without finding a taker. Mr. Woodruff, in his "Trotting Horse of America," says of Daniel D. Tompkins, that "he was a good little horse with pluck enough for the biggest that ever trotted." He was afterwards owned by Mr. William Fetterall, of Philadelphia. 
He had a fine full eye, was low over the withers, with an oblique shoulder, and fine back and muscles.

\section{FANNY PULLEN.}

Sorrel mare, $15 \frac{1}{4}$ hands high, and weighed 1,000 pounds, foaled about 1825, bred by Sullivan Pullen, of Anson, Me., got by Winthrop Messenger, dam, a bay mare, pedigree unknown. Mr. Pullen sold her, when seven or eight years old, to H. Stone, who then kept the Somerset Hotel at Anson. He sold her, shortly afterwards, to John Swan, of Anson, who trained her a few months and took her to Boston, in 1832 or '33, and sold her to a Mr. Lull, for $\$ 300$. She remained in Boston one season, and trotted a number of races on the Dedham turnpike against a pacer and a trotting mare called Blinker. She was then taken to New York. "In 1835," - see the Horse of America by Frank Forrester, vol. ii., page 158,_" the sport of trotting became more and more popular, and there was a scarce a gentleman in New York who did not own and drive one or two fast horses. Among the patrons of this noble sport, then in its infancy, I can name now Mr. Coster, with Fanny Pullen, the mother of the incomparable Trustee." In 1836 Harry Jones had Fanny Pullen, and she was entered in a sweepstakes race, two-mile heats in harness, over the Centreville Course, against Dutchman and Confidence, for $\$ 1000$. The betting ran very high on the race. Dutchman won it in two heats, and Fanny, second; time $5.17 \frac{1}{2}-5.18_{\frac{1}{2}}$. The first heat was the fastest two miles that had been made in harness.

This closed her public performances. She was subsequently purchased by Mr. James Bridges, and bred to Imported Trustee. 
Her first colt, called by Frank Forrester the "incomparable Trustee," and widely known as Trustee, the twenty-miler, was the first horse to trot twenty miles inside an hour, which he accomplished in ' $59,35 \frac{1}{2}$.

The race against time took place over the Union Course, Long Island, on Friday, Oct. 20, 1848, and Trustee won for himself imperishable renown as a trotting-horse, and accomplished at his own gait what it is not, by any means, every thoroughbred hunter that can perform at a gallop." "An hour after the match," says the editor of the Spirit of the Times, "we visited Trustee in his stable; he exhibited no distress, and on the following day was as fine as silk. We have seen him half a dozen times since, and he never looked or trotted better. $\mathrm{He}$ is a prodigy, but blood will tell.",

Mr. Bridges bred another colt out of Faniy Pullen, by Imported Trustee, an own brother to the twenty-miler. This colt was the sire of the dam of the renowned George M. Patchen, and was himself a fast and stout trotter. He was gelded young, and was driven for many year's by a gentleman in Westchester county. In 1839, Fanny Pullen was purchased of Mr. Bridges, and taken to Boston, by Mr. Spencer J. Vinal, of that city. She was at that time about 15 years old. Mr. Vinal kept her several years, and finally had her killed, and dumped off Commercial Wharf into the dock. Dr. Woods, the veterinary surgeon, preserved one of her fore-legs.

Fanny Pullen was a pale sorrel, with a coarse hip, low over the withers, and trotted down-headed. Under the saddle was her place to trot fast.

In looking over the history of Fanny Pullen, I find I have omitted two races in which she was engaged. They are as follows: August 20,1835, at Harlem, N. Y., she won 
a race, beating Crazy Jane and Snowball. Time, 2.44, 2.36, 2.33, 2.35. Crazy Jane winning the third heat. Oct. 15, following, at the same place, she beat Crazy Jane and Fire Fing, in 2.33, 2.37, 2.40.

While Fanny Pullen was owned in Anson, Mr. Pullen raised three colts from her. The first resembled his dam in color and general appearance. After having several different owners, Mr. Swan trained him awhile and took him to Mass., and sold him about the time he did his dam. Her second colt was a sorrel, with a white stripe in the face. He too was sold young, and taken out of the State. Her third colt was a gray mare, and like the others was sold young, and taken away, and all trace of her lost.

By the untimely death of John Swan, the only man, probably, who could give their whole history, all trace of them is lost beyond recovery. The gray mare, "Celeste," and chestuut geiding, "Henry," with many others, passed through his hands, and some of them were, doubtless, descendants of Fanny Pullen.

\section{ZAC TAYLOR,}

Sometimes called "Gen. Taylor," was a sorrel gelding, $15 \frac{3}{4}$. hands high, foaled in 1841, bred by Dr. Safford, of West Gardiner, Me., got by Quimby Messenger, dam, a mare used on the stage from Augusta to Bangor, and said to be well bred. Benjamin Hodges, of Hallowell, bought him in the winter of 1846 , and-sold a one-half interest to Capt. Sager, who then kept the Hallowell House, and they sold him, the following March, to Oliver Walton, of Boston. He was afterwards owned by C. P. ReIf, of Philadelphia. Mr. Woodruff says "he was a rery famous trotter and sticker." He trotted successfully against Lady Suffolk and Tacony. Nov. 8, 1848, he won 
a race, at Philadelphia, against Grey Eagle, under saddle, for $\$ 2,000$, winning the first, third and fourth heats, in $232,2.33,2.38$. Oct. 15,1850 , at the same place, he distanced Lady Moscow, in the first heat, in $2.30 \frac{1}{2}$.

May 6, 1852, he beat Lady Suffolk and Jack Rossiter, at the Union Course, Long Island. June 18, at the Centreville, he beat Tacony. July 14, at Boston, he beat Lady Suffolk, and July 20 he beat her again at the same place.

Oct. 13, same year, at Philadelphia, he beat Murdock, and Oct. 18 he beat him again, in straight heats, in 2.31, 2.29, 2.29. May 6, 1856, at Mobile, Alabama, he beat Belle Creole and Butcher Boy, both pacers, under saddle.

\section{TOM BENTON.}

Sorrel gelding, with star in the forehead, $15 \frac{1}{2}$ hands high, foaled in 182-, got by Winthrop Messenger; and was formerly owned in Bangor, by Mr. Strickland. He was finally taken to Mass., and trotted in the thirties.

\section{BELLE OF PORTLAND.}

Sometimes called Lady Walker. Dark bay mare with black points, 11 x.3 high, foaled in 1850, bred by Josiah Hinkley, of Mercer, Me., got by Witherell, dam, pedigree unknown.

Hinkley sold her to Dr. Boland, of New Sharon, and he to Hannibal Belcher, Esq., of Farmington, in August, 1854. In $1855 \mathrm{Mr}$. Belcher sold her to Oliver Walton, of Boston, for $\$ 175$, and Walton took her to Winthrop, shortly afterwards and sold her to William Beals. Mr. Beals sold her to James Jack, of Portland, and he to James Irving, of New York.

In 1857, at the Union Course, July 29, she won a race 
against Harry Walton, in which he was distanced in the second heat, for a purse of $\$ 2000$.

At the New City Course, N. Y., Oct. 10, 1861, she won a race against George Cooley and Pill Doctor, in which four heats, all under 2.30 were made. Belle of Portland winning the fastest in 2.26. She was subsequently purchased by Mr. J. J. Burgess, and died on the farm of her owner at Belleville, New Jersey, on Friday, Feb'y 1st, 1867. Wilkes' Spirit of The Times, of Feb'y 9, 1867, in speaking of the death of the "celebrated trotting mare, Belle of Portland," says: "she was in her day, one of the best and gamest trotters on the turf, and gave promise during last fall of coming back to her old condition, and of being able to repeat, in the coming spring, some of her previous exploits. It was the intention of her owner to have trotted her for one season more, and then to have retired her finally for breeding purposes."

It may not be uninteresting to state that Mr. Belcher sold her for $\$ 175$, because she was unable to see anything after it became dark.

\section{BELLE STRICKLAND.}

Sorrel mare with white stripe in face, and one white ankle, 16 hands high, and weighed 1080 pounds at four years of age, foaled June 4, 1860, bred by Mr. Dobson, of Harmony, Me., got by the Merrow Horse, dam, by Witherell.

She was sold when two years of age to Mr. Bemis, of Wellington, and he sold her in January, 1S64, to William H. Strickland, of Bangor, for $\$ 200$. Mr. Strickland sold her to Mr. Manson, of Farmington, Mass., for $\$ 700$, and she afterwards became famous for her performances on the turf.

Aug. 21, 1868, at Boston, she beat Madawaska Maid, Em- 
peror, Belle Morrill, and Lady Rogers, in three straight heats, distancing the two last named in the first heat. Time, 2.28, 2.32, 2.31. Aug. 24, she beat Detective in straight heats, in $2.38 \frac{1}{2}, 2.47 \frac{3}{4}, 2.28 \frac{1}{4}$, at the same place.

Sept. 8, at Springfield, she beat Fames Morgan, and Britain, in straight heats, fastest, $2.34 \frac{1}{2}$.

Sept. 18, at Worcester, she beat Gen. McClellan; fastest heat, 2.30 .

Oct. 5, 1869, at the Narragansett Park, in a race for double teans, Belle Strickland, and Black Harry, won the race, beating five other teams, viz.: Honest Allen and Jessie Wales; Lydia Thompson and Idle; India Rubber Ben and Lady Walton; Garibaldi and Darkness; Commodore Nutt and Sorrel John; distancing the two last named in the first heat. The fastest heat was 2.30. At Boston, Sept. 18, 1870, she beat Surprise, Harry Harley, and four others, in $2.27,2.28 \frac{1}{2}, 2.28$.

Oct. 4, 1870, she beat Chas. E. Loew, Harry Harley, and seven others, in straight heats, in $2.26,2.26,2.27$, for a purse of $\$ 2,000$.

She was afterwards purchased by a Mr. Bates, of $\mathrm{New}$ York, for $\$ 13,000$, and driven in single and double harness, as a road horse.

\section{DRESDEN.}

Bright bay gelding, with black points and no white marks, 15 hands high, and weighed about 925 pounds, foaled in May, 1862, bred by Albion Call, of Dresten, Me., got by the Call Hirorse (by Merrow), dam, a bay mare known as the Dr. Marble mare, pedigree, unknown. He was sold to Geo. M. Robinson, of Augusta, and he sold him to A. A. Thompson, of New York, for $\$ 2,000$.

June 25, 1869, at Narragansett Park, he won a race for 
horses that never beat 2.38 , winning the fastest heat in $2.34 \frac{1}{4}$.

Nov. 3, 1869, at Fashion, L. I., Dresden won the first heat in a race, in $2.30 \frac{1}{4}$.

\section{BEAUREGARD.}

Gray gelding, 15 hands high, foaled in 1863, bred by John Shaw, of Augusta, Me., got by Flying Mac; dam, pedigree, unknown. Mr. Shaw sold him to Mr. Smith, of Portland.

Aug. 19, 1870, at Skowhegan, Me., he beat Lady Burleigh, Cushnoc, and one other, in straight heats, 2.40, 2.41, 2.42 .

\section{FLEETING MOMENT.}

Bay mare, with black points, over 15 hands high, foaled about 1855, formerly owned by Mr. Doyen, of Waterville, got by Kennebec Messenger (Blake's); she afterwards came into John May's hands.

Oct. 2, 1867, at Boston, Mass., she beat Lady Morrill, the fastest heat being 2.39. Nov. 2, 1S67, at the same place, she beat Lady Morrill again, and the fastest heat was again 2.39 .

\section{SKEDADDLER.}

Brown gelding, with white strip in face, and white stockings behind, $15 \frac{3}{4}$ hands high, foaled in 1856 , bred by Oren Irish, of Peru, Me., got by Trustee Messenger, dam, by Rising Sun. He was purchased by Isaiah Pompilly, and taken to Stanstead, C. E., during the war. Here he obtained a record of 2.37 , in a race. He was afterwards taken lame, which prevented him from trotting. 


\section{EASTERN BOY.}

Light gray, nearly white gelding, of medium size, foaled May, 1859, bred by John Bowman, of Benton, Me., got by the Allen Horse, of Norridgewock, dan, the R. W. Pray mare (so called), of Messenger descent. June 20, 1871, at the Beacon Park, Boston, he won the three-minute race, in $2.35 \frac{1}{2}, 2.38 \frac{3}{4}, 2.37 \frac{1}{4}$. June 29, at the Mystic Park, he obtained a record of $2.32 \frac{1}{4}$. July 27 , he won a race at Haverhill, Mass., fastest heat, $2.35 \frac{1}{2}$.

\section{LADY WALTON.}

Gray mare, $15 \frac{1}{4}$ hands high, foaled in 1867 , bred by Mr. Walton, of Norridgewock, got by the Allen Horse (?) dam, by Witherell.

Samuel H. Jacobs, of Skowhegan, bought her when five years old.

June 14, 1873, at the Forest City Park, Portland, she won a race, beating Purity and Grace. June 18, at the Lewiston Driving Park, she won a race in three straight heats, the fastest being 2.41. The next day, June 19, she won the 2.50 purse; and the day following, the 20th, she beat a field of five horses, in three straight heats. She was afterwards taken to Massachusetts.

\section{WHITE STOCKINGS.}

Chestnut gelding, with four white feet, and stripe in face, $15 \frac{3}{4}$ hands high, foaled about 1856 , bred by Mr. Cummins, of Belgrade, Me., got by Witherell, dam, pedigree, not traced. He was taken to New York, where he trotted many races, in good time. He was finally brought back to Maine, and owned by John H. May, of Augusta. He won several races in Maine, during the season of 1873 . At the Maine State Fair, at Bangor, Sept. 19, 1873, he 
beat Gęn. Lightfoot in three straight heats, in 2.40, 2.37, $2.34 \frac{3}{4}$.

\section{BAKER BOY.}

Bay gelding, 16 hands high, foaled in 1866 , owned by $J$. E. Burnham, Houlton, Me., got by Woodbrook Messenger, dam, not traced.

\section{CELIA.}

Formerly called "Arcola," sorrel roan mare with light mane and tail, white in face and white stockings behind, 15 hands high, bred by Jefferson Pennell, New Portland, Me., got by Witherell.

Pennell sold her to Mr. Mallett, of Bath, he to Joseph Kilgore, of Portland, and he to New York parties. As "Arcola" she won a race at Portland, Me., Oct. 30, 1868, in straight heats each just 2.40, beating Fleeting Moment and Tempest. June 10, 1869, at Boston, she won the second and fourth heats, in a race in $2.36,2.38$. As "Celia" she won the second and third heats, in a race at Syracuse, N. Y., Sept. 1873, in 2.35, 2.343. July 24, 1873, she won a race at Auburn, N. Y., in straight heats, in 2.$36,2.36 \frac{1}{2}, 2.36 \frac{3}{4}$.

\section{ELISHA.}

Formerly called "Sharon Boy," sorrel gelding, with strip in face, and three white feet, $15 \frac{1}{2}$ hands high, foaled about 1855, bred by Charles Craig, of New Sharon, got by Witherell, dam, pedigree, unknown. Charles Emery, Skowhegan, bought him and sold him to James Balch, of New York. He was afterwards sold to George B. Alley, and was finally taken to California, where it is said he got a record of $2.26 \frac{1}{2}$ in an unpublished race. 
SORREL JOHN.

Sorrel gelding, $15 \frac{1}{4}$ hands high, foaled about 1844, bred by Mr. McClellan, of Skowhegan, Me., got by Witherell, dam, unknown. S. S. Parker, of Waterville, bought him when five years old, and sold him to J. F. Phillips, of Swampscol, Mass., and he was afterwards owned by S. J. Vinal, of Boston.

\section{LADY PACKER.}

Gray mare, foaled in 1860, taken from Maine to New York, by F. J. Nodine, of Brooklyn, got by Witherell, dam, not traced. Owned by Charles Backman, Stony Ford, Orange Co., N. I.

In 1869, foaled Sunbeam bay mare, by Idol, son of Rysdyk's IIambletonian. We have been unable to trace the above mare to her breeder, and take the above description and pedigree, from Vol. II., Wallace Trotting Register. In 1871, foaled brown gelding, Dazzle, by Messenger Duroc. 


\section{MORGAN STOCK.}

\section{JUSTIN MORGAN.}

Next to Winthrop Messenger, Maine is probably more largely indebted to the descendants of the famous Justin Morgan, for whatever speed she may possess, than to any other source. This horse, Justin Morgan, was a dark bay with black points, and no white marks, about 14 hands high and weighed about 950 pounds, foaled in 1793 , bred in Springfield, Mass., and died near Chelsea, Vt., in the winter of 1821; got by True Briton; also called Beautiful Bay. Mr. Wallace in his Trotting Register, Vol. II., says: "It is altogether probable that the sire of Justin Morgan was thoroughbred, and that his dam had some of the blood of Lindsey's Arabian, in her veins." He was blood-like in his appearance, but there is no evidence that he was a trotter of any considerable speed.

Among his descendants, who have been in the stud in Maine at different times, are the following-viz.:

Morgan CAsSAR, taken to Maine, in 1833, or 34, by Spaulding Smith, of Wilton, and was known in Maine, as "Morgan Post Boy;" got by Woodbury, by Justin Morgan, dam, by Quicksilver. He was the sire of Mac, Pizarro, etc., etc. He was taken to Vermont, in 1842. 
Morgan Rattler, known in Vermont as Royal Morgan, was brought to Maine, when a colt, and kept until 1829, when he was taken to Derby, Vermont; he was also known as the Steele Horse, Crane Horse, and in some places as the Chamberlain Colt; got by Sherman, by Justin Morgan, dam, by Justin Morgan.

Young Burbank, brought to Maine about 1842, and owned by Mr. Farrar, of Buckfield, got by Woodbury, by Justin Morgan, dam, by Post Boy.

Morgan TrotTer; brought to Maine about 1828, got by Bulrush, by Justin Morgan; dam's pedigree unknown.

Morgan Rat, foaled in 1822, and brought to Maine when young, and kept in the vicinity of Norway, got by Sherman, by Justin Morgan.

ENField Horse, brought to Maine about 1835̃, got by Woodbury, by Justin Morgan, dam of the celebrated Janus stock.

Matchless, foaled in 1851, and taken to Maine about 186-, and owned for a time by Spaulding Smith, of Wilton, got by Prince Albert, by Green Mountain 2d, he by Gifford, by Woodbury, by Justin Morgan, dam by Imported Trustee; was a celebrated roadster, and was formerly owned by Hiram Woodruff.

There may have been, and doubtless were others of the old Morgan stock, brought into the State from time to time. Bulrush, a son of the original Justin Morgan, stood for service in the State in 1831 and '32. Sherman, another son, was driven from Lyndon, Vt., to Portland, Me., in a team for several years, and left some descendants in Maine. 


\section{WHALEBONE.}

Sometimes called the "Clark Horse," was a chestnut stallion, about 15 hands high, and weighed 975 pounds, foaled in 1830, bred by Robert Bradley, Fryeburg, Me., got by Sherman, by Justin Morgan; dam, not traced. Mr. Bradley sold him to Merrill Wyman, also of Fryeburg, and he in 1840, when ten years old, to Gen. Philo Clark, of Turner, for $\$ 350$. Gen. Clark kept him until 1853, and he was then sold to Alvah Merrill, also of Turner, for $\$ 100$. He had become partially paralyzed some three years before, in consequence of an injury. After having several different owners, he died in Phillips, Me., in 1858. He was a horse of fine style and carriage, and was a favorite parade horse. In all his leading characteristics, he bore a striking resemblance to the best type of the Morgan breed of horses, and always exhibited in a high degree, those qualities that have given them their justly earned celebrity.

\section{POLLARD MORGAN.}

Black stallion, with white in face, about 15 hands high, and weighed about 950 pounds, foaled in 1847, bred by Col. James Hersey, of Sumner, Me., got by Whalebone, dam of Messenger descent. Col. Hersey sold. him when three years old to Demus Ricker, of Hartford, for $\$ 65$, and Ricker sold him when five to Maj. Isaac Strickland, of Brettun's Mills, Livermore. Strickland sold him to Lewis Pollard, of Turner, and he to Dr. Alonzo Garcelon, of Lewiston.

\section{PRINCE MESSENGER.}

Perhaps better known as the "Guild Horse." Black stallion, with star in forehead, 15 hands. high, foaled in 
1840, bred by Lauriston Guild, of Sidney, Me., got by a horse brought into Sidney about the year 1838, from Vermont, and known as the Lovejoy horse. He was said to be a Morgan horse, and is described as a "blood-like looking animal of about 1000 pounds, bay, with black points, head good, with prominent eyes, body round and deep, loin faultless, hips long, limbs perfect and clean of hair." The dam of the Guild Horse was by Old Winthrop Messenger, and he was said to have been "superior to his sire in beauty and quality." When four years old he met with an accident, injuring his hip so that he was lame ever afterwards. After being owned in Sidney several years, Mr. Guild sold him to his brother Samuel Guild, of Augusta. He finally sold him, and he died shortly afterwards.

\section{YOUNG MORGAN OTHELLO.}

Dark chestnut stallion, $15 \frac{1}{2}$ hands high, and weighs 1100 pounds, foaled in 1864, bred by James Philpot, A tkinson, Me., got by Morgan Othello, he by a son of Sherman Morgan, dam, by a Whalebone colt, out of an English blood mare.

\section{MORGAN ECLIPSE.}

Blood bay stallion, with black points and narrow white stripe in face, 17 hands high, and weighs 1300 pounds, foaled May 28, 1868, bred by Theodore Woodcock, Jr., Ripley, Me., got by a Morgan horse, dam, of Messenger descent.

\section{GEN. GRANT (GRANT'S).}

Black stallion, with star and one white hind foot, foaled June 6, 1861, bred by E. Cummings, Eddington, Me., got 
by the Hunter Morgan (?) of N. H., owned by W. H. Grant, Waltham, Me.

\section{MAC.}

Dark chestnut or brown gelding, with black tail and mane, and no white marks, $15 \frac{1}{2}$ hands high. He was foaled in 1843, bred by Thomas Record, of Canton, Me., got by Morgan Cæsar, better known in Maine as Morgan Post Boy, owned by Gen. John M. Eustis, of Dixfield, Me., who at one time owned old Winthrop Messenger. Morgan Cæsar was by Woodbury, he by Justin Morgan, dam, by Quicksilver. Mac's dam was a large powerful brown mare, by Bush Messenger.

Mr. Record sold him when three and one-half months old, to Mr. Samuel Harlow, of Canton. Mr. Harlow kept him a stallion, until the fall after he was three years old, during which time he got about fifteen colts; Mr. Harlow then gelded him, and in December, 1846, sold him to Ambrose Merrill, of Hallowell, for $\$ 95$; Mr. Merrill sold him to Benjamin Hodges, of Hallowell, for $\$ 300$; Hodges sold him to Oliver Walton, of Boston; he to Harry Jones, of New York, who in turn disposed of him to Mr. John McArdle, of Albany, who named him. Mr. Woodruff says, "Mac was a very famous horse and very fast." June 5th, 1849, he won a race at Providence, R. I., under saddle, in three heats, the fastest of which was 2.$29 \frac{1}{2}$, beating Lady Suffolk, and two others. June 14, he trotted on the Cambridge Course under saddle, against Lady Suffolk, and Gray Eagle. The first heat was Mac's in 2.31 and the Lady second, Gray Eagle was then drawn. The Lady won the second heat, in 2.26, and Mac won the other two in 2.27, 2.29. On the 9th of July, at the Union Course, L. I., he beat Lady Suffolk, in four 
heats. On the 10th, he trotted two-mile heats, under saddle, against Lady Suffolk, and Jack Rossiter, and won in two heats, the Lady being last in the first heat, and then drawn; the time was 5.9, 5.18. Frank Forrester in his "Horse of America" says, "Mac's performances in 1849 were enough to prove him, what he was, a first-rate animal for his day. He made his mile once in 2.26 , and his two miles in 5.9, 5.10." The last race of which we have any knowledge, in which he was engaged, was on the 5th of October, 1854, against Flora Temple, mile heats, three in five, in harness, for a purse of $\$ 1000$. John McArdle still owned him, and he had been injured by over driving, and had got "the thumps," still he was very famous for his many contests with Tacony, and when matched with Flora Temple, was thought to be as good as anything out. But the mare beat him with great ease in three heats, the fastest of which was $2.31 \frac{1}{4}$.

\section{WHALEBONE.}

Chestnut gelding, $15 \frac{1}{2}$ hands high, with white in face, and white hind foot, foaled in 184-, got by Whalebone, dam, not traced.

He was owned in Portland, by George Babcock, afterwards by Mr. Thompson, of Roxbury St., Boston, thence to New York, into George Hall's hands. In June, 1856, on Long Island, he trotted a double-team race with Lantern, against Stella, and Alice Gray, beating them in 2.42 , which was at that time the fastest on record in that way of going, and was considered a remarkable performance.

\section{BLACKSTONE BELLE.}

Black mare, under 15 hands high, foaled in 1856 , bred by Washington Treat, of Canton, Me., got by Whale- 
bone, dam, pedigree, unknown. Treat sold her when two years old, to E. Goding, of Jay Bridge, and he to Mr. Richardson, also of Jay, and she was afterwards owned by Joseph Rowe, Albert Hines, Ezra.Barden, and others, and finally by George Burnham, of Portland. From Portland she went to Boston, where she become the property of Mr. Thomas Trant, corner of Washing. ton and North Hampton Sts.

Here she became quite noted for her performances on the turf. May 24, 1865, she trotted a matched race for $\$ 1000$, against a horse called Gen. Grant, over the Riverside Park, winning in three straight heats, with such ease that it was evident that she was only driven to win; time $2.38,2.43 \frac{1}{2}, 2.44$.

Her best performance, and that in which she won her fastest record, was at Boston, July 2, 1866, in a race against Fanny Allen, for $\$ 5000$, which she won in three straight heats, in $2.28 \frac{1}{2}, 2.30 \frac{1}{2}, 2.31$.

\section{LADY HAMLIN.}

Chestnut mare, about 15 hands high, foaled about the year 1850, bred by Freeman Teague, of Buckfield, Me., got by Whalebone, dam, also of Morgan descent. Teague sold her when young to Lewis Chase, of Buckfield, and he to the Russell Brothers. They took her to Stanstead, C. E., where she trotted in a race against Kettlebail.

She was afterwards taken to Washington, D. C., where she trotted several races, low down in the thirties.

\section{LEWISTON BOY.}

Roan stallion, 15 hands high, and weighs 950 pounds; foaled in 1853, bred by Samuel D. Garcelon, Lewiston, Me., got by Pollard Morgan, dam, by Quimby Messenger. 
He was purchased when young by Mr. Samuel Smith, and sometimes called the "Smith Horse." He was sold and taken to Massachusetts, and July 3d, 1866, he won a race at Boston, beating Brewer Boy, and Honest Abe, the fastest heat being 2.36. He was afterwards brought back to Maine, and was for a while owned by H. B. Pinkham, of Brunswick, who sold him in 1872, to go to Boston.

\section{AUBURN BOY.}

Chestnut gelding, with white strip in face, $15 \frac{3}{4}$ hands high, foaled in 1864, bred by Dr. D. B. Strout, of Auburn, Me., got by Lewiston Boy, dam, not traced.

Dr. Strout sold him in 1870 , to N. C. Hutchins, of Chesterville, and he was subsequently purchased by Messrs. Wright and Norcross, of Fearnaught Farm, Manchester. Among his performances on the turf are the following:--June 20th, 1873, at the Lewiston Driving Park, he won a race, beating Lady Amazon, and Gentle Annie. July 4th, 1873, he won a race at the same place, beating Lady Amazon, in three straight heats, the fastest being 2.41. Previous to this, May 30, at the Mystic Park, Boston, he won the last three out of four heats, in a race in $2.37 \frac{1}{2}, 2.40,2.39 \frac{1}{4}$.

\section{SUSIE.}

Chestnut mare, with small star in forehead, $14 \frac{3}{4}$ hands high, foaled in 1864, bred by W. S. Mitchell, Dixfield, Me., got by a Morgan horse, brought from Vermont, by Asa Gile, Esq., of Readfield; dam, by the Libby Horse. Mitchell sold her when six years old, to Wilson and Ricker, of Brighton, Mass. While owned in Maine, she 
trotted several ice races, and rras considered fast, but had no record.

\section{KETTLEBAIL.}

Bay mare, with white stockings behind, and star in forehead, foaled about 1850 , bred by William Young, of Auburn, Me., got by the Pollard Morgan, dam, by Whalebone. She was sold to I. Pompilly, and trotted several races, in good time in this State. Her fastest public record, was $2.31 \frac{1}{2}$, at Stanstead, C. E., while owned by Mr. Pompilly. She was afterwards brought back to Maine, and is still, we think, kept in Lewiston or vicinity.

\section{LEWISTON LADY.}

Roan mare, 15 hands high, and weighed 875 pounds, foaled in 1860, bred by Josiah Littlefield, of Auburn, Me., got by Lewiston Boy. Littlefield sold her when young to Mr. Mitchell, of Lewiston, and she was sometimes called the "Mitchell Mare." When young she trotted quite fast, getting a record of $2.41 \frac{1}{4}$, at Lewiston. She afterwards passed through many different hands, until in 1872, she was sold and carried out of the State.

\section{LADY CHAPMAN.}

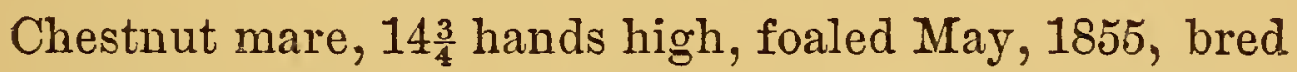
by Andrew Grover, of Bethel, Me., got by a Morgan horse, brought from Vermont, and known in Bethel and vicinity as the "Eames Horse," dam, a large mare, pedigree, unknown. Lady Chapman was purchased when three months old, by Gilbert Chapman, of Bethel. Mr. Chapman sold her, and after passing through several different hands, she became the property of D. H. Bisbee, 
Esq., Camden, Me. Oct. 2d, 1868, at Rockland, she won a race, beating Black Walnut, and Right Bower, the fastest heat being 2.40 , which we believe is her fastest record, although she has trotted on ice, very fast. In the winter of 1872-73, she was purchased by Messrs. Wright and Norcross, and taken to Fearnaught Farm, to be used for breeding purposes.

\section{PRINCE BISMARK.}

Bay gelding, with white strip in face, foaled June 15 , 1869, bred by O. W. Tilton, West Waterville, Me., got by a horse that came from Vermont, of Morgan blood, called Brandywine, dam, a Witherell mare.

\section{MORGAN BILLY.}

Dapple bay stallion, with black points, and two white feet, 15.2 hands high, and weighs 1,000 pounds, foaled in 1866, bred by Moses Mason, Gilead, Me., got by a Morgan horse, dam, an English pacing mare.

\section{HIRAM DYER.}

Bay brown stallion, with star in foreliead, foaled May 11, 1864, bred by J. F. Dyer, Presque Isle, Me., got by the West horse (so called) by Morgan Cresar, he by Gifford Morgan, dam, Morgan and English. June 25, 1873, Hiram Dyer won a race in three straight heats at Bangor, Me., time $2.43 \frac{3}{4}, 2.45,2.45$.

\section{PADDY.}

Black gelding, with white crescent in forehead, and one white hind foot, about 16 hands high, foaled in 1866 , bred by Galen Gates, Carroll, Me., got by Morgan Paddy. 
dam, a fast trotting mare, called "Fan," her dam an English thoroughbred mare. Paddy was sold when four years old to B. W. Blanchard, also of Carroll.

At the Maine State Fair of 1873 at Bangor, Paddy won

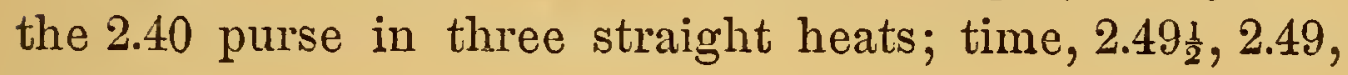
2.41 .

He was afterwards sold to Mr. Owen Dugan, of Bangor.

\section{BAY DICK.}

Dark bay gelding, with black points, and no white marks, 16 hands high, foaled in 1863, owned by Johnson and Phair, Presque Isle, Me., got by the West Horse, by Cæsar Morgan, by Gifford Morgan, by Woodbury, etc., dam of Bay Dick, by Moscow, by old Moscow. Bay Dick won three races out of four in which he started in 1873 and made a record of 2.47 . 


\section{DREW STOCK.}

OLD DREW.

The originator of the famous Drew breed of horses was a dark brown bay stallion, with black points, $15 \frac{1}{4}$ hands high, and weighing, in good condition, about 1000 pounds; of genteel form, and fine style and action, but like all our older horses, he was untrained to trot. His appearance has been described as follows, by one who saw him shortly before his death: "Shoulders extremely high, broad and deep, neck light at the head, well arched, and deep at the body; face a little rounding, eyes not very prominent, ear's good length and well cut, body small, loins a trifle arched, hips very long and beautifully turned, limbs large, pasterns long, feet high, black and nice, mane spare, tail in waves, and hair short and fine all over the body."

He was foaled in May, 1842, bred by Hiram Drew, then of Exeter, Me., and dropped on his father's farm, where he then lived.

He was got by a three-year-old bay colt, 16 hands high, said to be thoroughbred. Said colt was bought of an English officer in Fredericton or St. John, N. B., and brought to Maine by $\mathbf{A}$. G. Hunt, then of Exeter. His dam was said to have been brought from England in foal 
by a thoroughbred running horse, and this colt being the produce. At Exeter, Mr. Hunt turned him into his pasture which joined Mr. Drew's, from which he was taken several times. Here in Mr. Drew's pasture he sired the colt afterwards known as the Drew horse, which is probably the only colt he ever got, as Mr. Hunt had him castrated shortly after, and sold him. The dam of old Drew was a bay mare, afterwards taken to Boston, and known as Boston Girl. (See Boston Girl.)

Although the statements of different parties concerning the pedigree of the old Drew horse are somewhat vague and unsatisfactory, it is clearly established that he was a highly bred horse, and surely the generations that have sprung from him should be conclusive in regard to the purity of his blood. He imparted the trotting faculty to his offspring in a remarkable degree. He never passed out of Mr. Drew's hands. He died in Mr. Burrill's stable in Fairfield when 24 years old. He was found in his stall in the morning with his leg broken, and had to be killed.

\section{GEN. MCCLELLAN.}

Bay stallion with black points, $15 \frac{1}{4}$ hands high, and weighs about 900 pounds, foaled May 16, 1854, bred by N. B. Pease, then of Exeter, Me., got by old Drew, dam by Shark, said to be a son of imported Shark. He was first called the "Pease colt," under which name he won a race at Bangor, Oct. 3,1861 , in straight heats, beating Penobscot Boy, time 2.40, 2.38, 2.35. Pease sold him to George M. Robinson, of Augusta, in 1861, and he was called Gen. McClellan. Sept. 24, 1864, while owned by Mr. Robinson, he won a race at Belfast, beating Geo. B. McClellan (now called Dirigo), winning the second heat 
in 2.31 , the third in 2.28 , and the fourth and race in 2.26 . Robinson sold him soon after to Shaw \& Stoddard, of Bangor. Sept. 21, 1865, at the Riverside Park, Boston, he won a race in straight heats, beating Leviathan and Ticonic, time $2.33 \frac{1}{4}, 2.32 \frac{1}{2}, 2.34 \frac{3}{4}$. Two days after at the same place, he won a race against Fearnaught, to wagons, in straight heats, the fastest being 2.37 .

Oct. 17, 1866, at Boston, in a double-team race with Dashaway against Ethan Allen and Honest Allen, mile and repeat, Gen. McClellan and mate won in two heats in $2.39 \frac{1}{4}, 2.39 \frac{1}{8}$.

June 10,1867 , he won a race of four heats, to wagons, against Commodore Vanderbilt, at the Fashion Course, L. I. for a purse of $\$ 2000$. Mac won two heats in $2.30 \frac{3}{4}$ each, and one in $2.31 \frac{1}{2}$.

He was subsequently purchased and taken to California by M. J. Lewis, Esq. Here he won a race at Sacramento, since which time he has been in the stud at San Francisco, Stockton, and other places in that State, making the season of 1873 at Oakland, Alameda Co.

\section{DIRIGO.}

Formerly called "Geo. B. McClellan," brown stallion with black points, $15 \frac{1}{2}$ hands high, and weighs about 1050 pounds, foaled in 1856, bred by the late Horace McKenney, of Monroe, Maine, got by old Drew, dam, a well bred mare, said to be nearly thoroughbred. McKenney sold him in 1864 to Capt. Sanford, of Bangor, for $\$ 7000$, and he was subsequently purchased by David Quimby, of Corinna, Maine. He is a horse of fine style and carriage, and not only one of the fastest walking stallions in the country, but is a horse of the finest speed and courage as 
a trotter. Indeed, he is regarded by many as the most famous son of the old Drew horse. He has been very successful in the stud, and is the sire of Little Fred, Black Walnut, Bully Brooks, Hard Road, Maine Girl, and many others of note. In 1864, Sept. 24, in a race against Gen. McClellan at Belfast, he won the first heat in 2.29 , since which time he has been kept wholly for stock purposes.

\section{JOHN BRIGHT.}

Bay stallion with black points, $15 \frac{1}{2}$ hands high, foaled in 1860, bred by Warren Pratt, of Corinna, Me., got by old Drew, dam, by Witherell. When four years old, Samuel H. Jacobs, of Skowhegan, bought him, and afterwards sold him to the Stoddard Bros., of Bangor, for $\$ 2600$.

\section{LISGAR.}

Bay stallion with black points, and star in forehead, foaled in 1868, owned by E. H. Stuart, Veazie, Me., got by Grey General by Gen. McClellan, dam, by old Drew.

\section{HIRAM DREW.}

Bay stallion with black points, $15 \frac{1}{4}$ hands high, foaled in 1849, bred by Oliver Clark, of Corinna, Me., got by old Drew, dam, a small bay Morgan mare. Mr. Clark sold him to Hiram Drew when two years old, for $\$ 100$.

He was first called Bay Morgan, under which name he won a race at Bangor, beating Blue Morgan, the fastest heat being 2.41. The above race took place Ang. 23, 1854 . July 5,1855 , in a race at the same place with Lady Litchfield and Stranger, he won the second heat in $2.31 \frac{1}{2}$.

When seven years old Mr. Drew sold him to Warren 
and Williams, of Boston, Mass., for $\$ 4,000$, and they called him Hiram Drew. He was brought back to Maine and trotted several races. Oct. 28, 1863, he won a race at Portland, Me., beating Gen. McClellan in straight heats in $2.42,2.36,2.43$. Oct. 26,1865 he won a race at Taunton, Mass., distancing his competitor in the second heat in $2.37 \frac{1}{2}$. He was afterwards taken to Philadelphia, and died there.

\section{INDIA RUBBER JOHN.}

Mahogany bay stallion with black points, small star in forehead, and a little white on near hind foot, $15 \frac{1}{2}$ hands high, and weighs 1050 pounds, foaled in 1868, owned by S. D. Parkman, PaImyra, Me., got by John Bright, dam, of Morgan descent.

\section{GOPHER.}

Sorrel stallion with star, foaled in 1871, owned by Jonathan Bates, Fairfield, Me., got by a son of Old Drew, dam, of Messenger descent.

\section{DON JUAN.}

Black stallion, with no white marks, $15 \frac{3}{4}$ hands high, foaled June 10, 1858, bred by W. H. Eastman, of Exeter, Me., got by Old Drew, dam, a bay mare of Messenger descent, called the Kennison mare. He was purchased in 1864, by Henry Taylor, of Waterville, afterwards owned by Gen. Wm. S. Tilton, of Togus, Me., and Waldo T. Pierce, of Bangor. He is said to have trotted in 2.38.

\section{NED DATIS.}

Mahogany bay stallion, $15 \frac{1}{2}$ hands high, foaled in 18-, bred by Mr. Davis, of Exeter, got by Old Drew, dam, not 
traced. He was afterwards owned by Geo. M. Robinson, and by Col. T. S. Lang, of Augusta.

\section{GEN. GRANT (RobINSon's).}

Dark chestnut stallion, with dapples, $15 \frac{3}{4}$ hands high, foaled in 1859, bred by a Mr. Atwood, near Bangor, got by Old Drew. Geo. M. Robinson, of Augusta, bought him when seven years old and sold him to J. B. Ham, of St. John, N. B.

\section{YOUNG MCCLELLAN (RoBINSON's).}

Bay stallion, $15 \frac{1}{4}$ hands high, foaled in 1866 , bred by Geo. M. Robinson, of Augusta, Me., got by Gen. McClellan, dam, by Guild Horse. Mr. Robinson had him gelded when four years of age, and sold him afterwards with his mate, also by Gen. McClellan, to Wm. Butler, of Providence, R. I., for $\$ 2,000$.

\section{YOUNG McCLELLAN (PETTiNgall's).}

Bay stallion, foaled in 1865, bred by Howard Pettingall, of Augusta, got by Gen. McClellan, dam by John B. Dunton. He was gelded when five years old, and sold when eight to Gen. Wm. S. Tilton, Togus, Me.

\section{PRINCE HAL.}

Sorrel stallion, $15 \frac{3}{4}$ hands high, foaled in 1865 , bred by Henry Robinson, Hartland, Me., got by Diamond, by Old Drew, dam, of Messenger descent. June 25, 1873, at Bangor, Me., he won a race in straight heats, the fastest being 2.43 . 


\section{PLOUGH BOY.}

Dark bay stallion, 15 hands high, weighs 950 pounds, foaled in 1865, bred by Samuel Crockett, Ellsworth, Me., got by Dirigo, dam, Morgan. Owned by A. J. Grant, Vinalhaven, Me.

\section{HAMPDEN BOY.}

Black stallion, 15 hands high, and weighs 960 pounds, foaled May 25, 1869, bred by A. R. C. Nealey, of Hampden, Me., got by Dirigo, dam, by a Black Hawk.

\section{BILL BAKER.}

Black stallion, $15 \frac{3}{4}$ hands high, weighs 950 pounds, foaled June 2, 1869, bred by E. D. Baker, Levant, Me., got by Doncaster, by Old Drew, dam, by Old Eaton.

\section{GAZELLE.}

Golden chestnut stallion, with white stripe in face, and a black stripe on his back, 15 hands high, and weighs 900 pounds, foaled May 29, 1870, bred by Albert Whitten, Searsmont, Me., got by Young McClellan, owned by David Malcomb, of China, he by Gen. McClellan, dam, Black Hawk.

\section{BADGER.}

Chestnut stallion, with star in forehead, $15 \frac{1}{2}$ hands high, foaled in 1869, owned by John D'Arthenay, A ugusta, Me., got by Robinson's Young McClellan, dam, also a Drew.

MCCLELLAN, JR.

Dapple bay stallion, with black points, $15 \frac{1}{2}$ hands high, and weighs 1050 pounds, foaled in 1868, bred by Henry 
H. Foster, of Freeman, Me., got by Gen. McClellan, (?) dam, of Messenger descent. Mr. Foster sold him when three years old, to Eben Ladd, of Industry, and he in 1872, to Richard Fassett, Jr.

\section{YANKEE BOY.}

Blood bay stallion, with black points, star in forehead, and narrow white stripe on nose, foaled in 1866, bred by Samuel Campbell, of Sangerville, Me., got by Red Jacket, owned by Russell Severance, of Bradford, Me., and. he, by Old Drew; dam, of Yankee Boy, by Sandy River Trotter.

\section{KING DREW.}

Black stallion, $14 \frac{1}{2}$ hands high, and weighs 925 pounds, foaled in 1865, bred by Ambrose Davis, of Palmyra, Me., got by Old Drew, dam, of Morgan descent. Owned by Charles L. Clement, Howard, Me.

\section{JOLLY BOATMAN.}

Gray stallion, $15 \frac{1}{2}$ hands high, and weighs 935, foaled in 1869, bred by Celia A. Dow, Monson, Me., got by Penobscot Chief, dam, of Morgan descent.

\section{GEN. GRANT (CHOATE's).}

Dark bay stallion, 15 hands high, and weighs 950 pounds, foaled in 1868 , owned by $\mathrm{A}$. Choate, (?) got by Young McClellan, dam, of Morgan descent.

\section{JIM FISKE.}

Stallion, got by the Mudgett Horse, he, by Old Drew, dam, of Defiance stock. Owned by G. C. Rowe, Canaan, $\mathrm{Me}$. 


\section{GEN. LYON (SHAW's).}

Dark bay stallion, 16 hands high, and weighs 1050 pounds, foaled in 1864, owned by Elihu W. Shaw, got by Gen. Grant, by Old Drew, dam, of Messenger descent.

\section{VON MOLTKE.}

Blood bay stallion, with black points, and no white marks, $1 \tilde{y}_{2}^{\frac{1}{2}}$ hands high, and weighs 1030 pounds, foaled in May, 1868, bred by James Morrison, Newburgh, Me., got by the Morrill colt, by Old Drew, dam, by the Merrow Horse.

A. W. Brackett, of Pittsfield, Me., bought him when young. In July, 1873, he trotted a trial in private in an

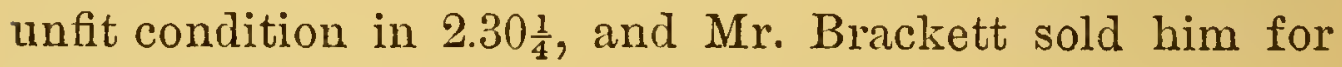
$\$ 7,000$, and he was taken to New York.

\section{GEN. LYON (PALMER'S).}

Dark chestnut stallion, with dapples, and no white marks, 16 hands high, and weighs 1100 pounds, foaled in 186-, bred by Arnold Palmer, Palmyra, Me., got by Diamond, he, by Old Drew, dam, of Gen. Lyon, by the Avery horse.

At the Maine State Fair of 1873, Gen. Lyon was awarded the First Premium in his class.

\section{GEN. GRANT (PROCTOR's).}

Dark chestnut stallion, with star in forehead, and one white hind foot, 17 hands high, and weighs 1280 pounds, foaled in May, 1866, bred by Mr. Gifford, of St. Albans, Me., got by Palmer's Gen. Lyon, dam, of Messenger descent. Gifford sold him when two years old to Charles Proctor, of Corinna, $\mathrm{Me}$. 
At the New England Fair in 1869, he took the second Premium as a three-year-old, and has taken several first Premiums at Penobscot County Fairs.

\section{PENOBSCOT CHIEF.}

Bay stallion with black points, $15 \frac{1}{4}$ hands high, and weighs about 950 pounds, foaled June, 1862, bred by $P$. M. Jefferds, Foxcroft, Me., got by Gen. McClellan, dam, a chestnut mare, $14 \frac{1}{2}$ hands high, said to be by Royal George, and out of the dam of Brown Harry. Mr. Jefferds sold him when four years old to O. M. Shaw, of Bangor, and he shortly after to Mr. Runkle, of New York, for $\$ 2000$.

\section{RED JACKET.}

Bay stallion with black points, 15 hands high, and weighs 900 pounds, foaled in 1864, bred by Charles Burkett, Appleton, Me., got by Hiram Drew, dam, of Morgan descent. In 1872, at the Maine State Fair at Bangor, he won a record of $2.39 \frac{1}{4}$. At the Maine State Fair of 1873 , also at Bangor, he won the third heat in the 2.35 race in 2.38 .

\section{DANIEL DREW, FORMERLY DR. PAXTON.}

Dark brown, nearly black stallion, 16 hands high, and weighs 1075 pounds, foaled in 1864, owned by N. H. Spaulding, formerly of China, Me., got by Old Drew, dam, by the Hunton horse. Mr. Spaulding is now in business in Boston, and Dr. Paxton has been standing for service in Rhode Island. Brought back to Maine, and called Daniel Drew. 


\section{WINTHROP (GREENE'S).}

Blood bay stallion with black points, 16 hands high, and weighs, in ordinary flesh, 1100 pounds, foaled in July, 1864, bred by E. J. Greene, Newport, Me., got by Old Drew, dam, by Old Eaton, second dam by Stone's Messenger. Mr. Greene sold him to his son, W. E. Greene, and he took him to California in 1870, where he is now owned by him and E. L. Yates, of Stockton, where he stands for service.

\section{JOE HOOKER.}

Bay stallion: with black points, 16 hands high, and weighs 1080 pounds, foaled in 1864, owned by G. M. Allen, Fairfield Corner, Me., got by the Geo. Wilkshire horse, by Old Drew, dam, of Messenger descent. He has a record of 2.44 as a four-year-old, and his owner claims that he has trotted a full mile to wagon in private in 2.29 .

\section{GEN. VALEJO.}

Dark bay stallion with black points, weight 1100 pounds, foaled in April, 1867, owned by Thomas Hersey, Bangor, Me., got by Penobscot Chief, dam, part Drew.

\section{YOUNG DIRIGO (STRATFARD'S).}

Black stallion, foaled June 15, 1864, owned by John Strattard, Monroe, Me., got by Dirigo, dam, a Black Hawk mare. Young Dirigo has taken a number of premiums at the Waldo and Penobscot County Fairs, and also the first premium, both for trotting and stock qualities at the County Fair held at Belfast. 


\section{TIGER DREW.}

Dark bay stallion with black points, foaled May 16, 1869, owned by C. E. Ritchie, West Winterport, Me., got by Young Dirigo, dam, a French Tiger mare. He was awarded the first premium in his class at the Fair in Monroe in the fall of 1872.

\section{LITTLE CLAUDE.}

Bay stallion with black points, 15 hands high, foaled in 1869 , bred by Charles B. Wellington, Albion, Me., got by Hiram Drew, he by old Hiram Drew, dam, a Morrill mare, said to be very fast. Little Claude won the race for three-year-olds at the Maine State Fair at Bangor in 1872.

\section{BATCHELDER HORSE.}

Formerly called Penobscot Boy. Bay stallion with black points, $15 \frac{1}{4}$ hands high, and "very handsome;" foaled in 1853, bred by George A. Batchelder, of Exeter, Me., got by old Drew, dam, a Canadian mare. Batchelder sold him to Frank Berry, and he was afterwards owned by Billy Morris, of Boston: He trotted on the Saugus track in 2.37 , in 1861 .

\section{BURROUGH BOY.}

Dark bay stallion with black points, $15_{\frac{1}{2}}^{\frac{1}{2}}$ hands high, and weighs 1000 pounds, foaled in 1867, bred by Isaac $\mathrm{H}$. Colton, Bowdoin, Me., got by Gen. Burnside, by Gen. McClellan, dam, by the Cox horse, by Young Vermont Hunter. Owned by Daniel C. Coombs, Bowdoin, Me. 


\section{YOUNG DIRIGO (CARPENTER's).}

Black stallion, 16 hands high, and weighs 1050 pounds, foaled in 1865, bred by Joseph Emery, of Monroe, Me., got by Dirigo. Owned by G. W. Carpenter, Glenwood, Aroostook Co., Me.

\section{GEN. HANCOCK.}

Roan gray stallion with black points, foaled June 18, 1860, bred by Horace McKenney, Monroe, Me., got by Dirigo, dam, by Bush Messenger. Owned by Ivory Grant, Bucksport, Me.

\section{COL. BROOKSVILLE.}

Dapple gray stallion, weighs 1000 pounds, foaled in June, 1868, bred by G. Soper, Orland, Me., got by Sweepstakes, by Old Drew, dam, by Old Lion. Owned by Edmond B. Gray, Brooksville, Me.

\section{AROOSTOOK BOY.}

Chestnut stallion, nearly 16 hands high, and weighs about 1050 pounds, foaled in 1866, owned by Nelson Herrin, Houlton, Me., got by Old Abe, he by Old Drew. Aroostook Boy obtained a record of 2.41 on the Houlton Park, July 4, 1873.

\section{SIROC.}

Blood bay stallion with no white marks, 16 hands high, and weighs 1000 pounds, foaled in July, 1870, owned by A. G. Hunt, Houlton, Me., got by Aroostook Boy, dam, an Eaton Messenger mare. 


\section{SHAKER DREW.}

Dark brown stallion, weighing over 1000 pounds, foaled in 1866, bred by Nathaniel Newell, of Alfred, Me., got by Hiram Drew, Jr., he by Hiram Drew, dam, a Morgan. Owned by E. E. Ling, Gorham, Me.

\section{BLACK DIAMOND.}

Black brown stallion, 16 hands high, and weighs 1100 pounds, foaled in 1866, bred by Thomas C. Mulvey, Hollis, Me:, owned by William H. Warren, Cornish, Me., got by Penobscot Boy, by Old Drew, dam, by the Chellis horse, being also the dam of Fanny Bradbury. Trotted Sept. 6, 1873, on Cornish track against Young Morrill in 2.51 .

\section{ROMEO.}

Dark bay stallion with black points, star in forehead, and white fore feet, 16 hands high, and weighs 1065 pounds, foaled in June, 1865, bred by L. Moore, Monroe, Me., got by Dirigo, dam, by the Twombly horse. Owned by T. Dunham, Monroe, Me.

\section{BLACK THORN.}

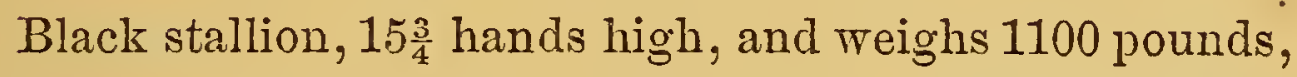
foaled in May, 1866, bred by Mr. Moore, of Monroe, Me., got by Plough Boy, dam, of Messenger descent. Sold when four months old to Joel Haley, Winterport.

\section{LITTLE FRED.}

Bay gelding, with black points, 15 hands high, foaled in 1860, in Swanville, Me., got by Dirigo, dam, an English mare, "brought from Prince Edward's Island. He was 
formerly owned by Charles Webb, of Thorndike, who sold him when five years old to Hugh Ross, for $\$ 300$, and he shortly after to Josiah Hight, of Athens. Hight sold him to Fred Dore, of Skowhegan, who next spring sold half of him to John Judkins, of Waterville, for $\$ 600$, and afterwards the other half for $\$ 1,200$. While owned in this State he trotted several races. In July, 1867, at Lewiston, Me., he won a race in three straight heats beating Gladiator, time 2.33, 2.31 $\frac{1}{2}, 2.30$. His last and fastest public performance was at the Prospect Park Fair Grounds, Brooklyn, May 29, 1869, where he won a race in straight heats, beating Needle Gun, Jessie Wales, Belle of Brooklyn, Old Put, and Lady Whitman. Time, 2.29, 2.28 $2.26 \frac{3}{4}$.

While trotting this race he struck or ruptured a tendon, and while under treatment a seton was applied that resulted in lockjaw, of which he died. During that very race Commodore Vanderbilt offered $\mathrm{Mr}$. Messerole, who then owned Fred, fifteen thousand dollars for him, and the offer was refused.

It is said that prior to this race he was driven a trial in

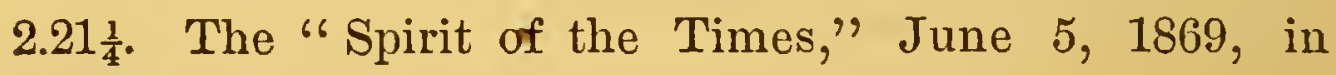
speaking of the race at Prospect Park, said, "Little Fred had the foot of the party. He got off in the lead at each start, was never headed, and won the heats with plenty in hand."

\section{STELLA.}

Black mare, with no white marks, 15 hands high, foaled in 1847, bred by Mr. Pease, of Stetson, Me., got by the Old Drew Horse. Sold to Joshua Seward, of Boston, and by him, to George B. Alley, of New York. She was the mate of Alice Gray, in the great double team race, 
against Lantern, and Whalebone, on the Union Course, L. I., June 5, 1855. She injured herself in the above race, and was sold to Robert $R$. Morris, New Rochelle, N. Y. She is supposed to be the mare known in Maine as Black Sal, which see.

\section{MARY DREW.}

Roan mare, foaled in 1860 , bred by Hiram Drew, of Exeter, Me., got by the Old Drew, dam, by Stone Horse. Sold to Abram Woodard, of Bangor, and by him, to $\mathrm{R}$. Ingraham, Brooklyn, N. Y. In 1871, foaled bay mare, " Dawn," by Peacemaker.

\section{FOX.}

Buckskin gelding, 16 hands high, foaled in 18-, bred in Hermon, Me., got by a son of Old Drew, dam, brought from Ohio. A. M. Savage, bought him for Mr. Messerole, of New York; where he was taken, and trotted in the thirties.

\section{TEMPEST.}

Black mare, with white ankles behind, foaled in 1860 , got by Dirigo; A. M. Savage bought her of Mr. Berry, of Rockland, and sold her to N. H. Leadbetter, of New York City. He sold her to J. C. Runcle, and he to Mr. Humphrey, the owner of Judge Fullerton.

\section{HONEST QUAKER.}

Light gray gelding, $15 \frac{1}{2}$ hands high, and weighs 1000 pounds, foaled in 1864, owned by Augustus Drake, Hope, Me., got by the James Mahoney horse, by Dirigo; dam, by Moody's Messenger, dam of Mahoney horse, by Bush 
Messenger, 2d. August 14, 1872, at Knox Park, Rockland, he beat Red Jacket in straight heats, fastest $2.41 \frac{1}{2}$.

\section{GENTLE ANNIE.}

Black mare, with star in forehead, $14 \frac{3}{4}$ hands high, foaled in 186-, in Bradford, Me., got by Dirigo. This, however, is disputed. She was formerly owned by S. H. Jacobs, of Skowhegan, who sold her to H. C. Burleigh, of Fairfield, Me. At the Maine State Fair of 1872, she obtained a record of $2.39 \frac{1}{2}$, and in $1873, \mathrm{Mr}$. Burleigh sold her to Prudent Letourneau, of Waterville.

\section{LADY DILLON:}

Bay mare, with star in forehead, 15 hands high, and weighed about 950 pounds, foaled in 185s, got by Old Drew. She was owned for several years by Nelson Herrin, of Houlton, Me. He sold her in 1873 to C. W. Clayton, of Masardis, and she was on the way thither, hitched to the rear: of a loaded team, when she met with an accident which caused her death. She won several races in good time, and had a record of one-half mile in 1.15.

\section{DOT.}

Gray mare, foaled in 1865, formerly owned by Abram Woodard, Bangor, Me., got by Old Drew, dam, by French Tiger. Mr. Woodard sold her to R. Ingrahan, Brooklyn, L. I. In 1872, she foaled Glaucus, bay horse, got by Norwood, by Rysdyke's Hambletonian.

\section{GIPSEY QUEEN.}

Brown mare, $15 \frac{1}{4}$ hands high, with no white marks, foaled in 18.55, bred by Nathaniel B. Pease, of Exeter, 
Me., got by Old Drew, dam, the dam of Gen. McClellan. Mr. Pease sold her to Abram Woodard, of Bangor, he to O. M. Shaw, and he to Boston parties.

\section{BLACK SAL.}

Black mare with no white, scarcely 15 hands high, foaled in 1847, bred by Elmer Pease, of Exeter, Me., got by Old Drew, dam, the Pease mare of Exeter, dam of Gen. McClellan; grand dam, a Black Hawk mare from Vermont. Pease sold her to Horace Shepley, of Stetson, and he to a gentleman in Cambridge, Mass. She walked a mile over the Bangor track in twelve minutes in 1853. It is said that she was afterward taken to Long Island, and trotted very fast under another name. She is said to have been very handsome, with a big open gait. Although not fully identified, this mare is believed to be the same as Stella, which see.

\section{LADY WARREN.}

Steel gray mare, about 15 hands high, foaled about 1855, bred by Hiram Drew, of Exeter, Me., got by Hiram Drew, dam, a gray mare of Messenger descent. Mr. Drew sold her to Charles Warren, of Brookline, Mass. Oct. 4, 1867 , she won a race at Northampton, Mass., beating Robinson's bay gelding and Regulator, winning the third, fifth, and sixth heats in $2.35 \frac{1}{4}, 2.40,2.41$.

\section{CONTRABAND.}

Dark brown gelding, with no white marks, I5 $\frac{1}{2}$ hands high, foaled in 1860, formerly owned by W. F. Titcomb, of Dover, and called "Dover Boy," got by the Mansell Horse, by Old Drew, dam, a sorrel mare, by Witherell. 
Titcomb sold him to William S. Briggs, of Taunton, Mass. Sept. 20, 1870, at Boston, Mass., he beat eight horses, winning the third, fourth, and fifth heats, and race, in $2.37,2.39,2.39$. Two days afterwards, Sept. 22, he beat four horses, in straight heats, at the same place, time 2.32 $\frac{1}{2}, 2.37,2.36 \frac{1}{4}$. Sept. 28, following, he beat Andy Johnson, Gipsey, Lady Hughes, Ferry Henshaw, Daylight, Lady Alice, and Shawmut, winning the second,

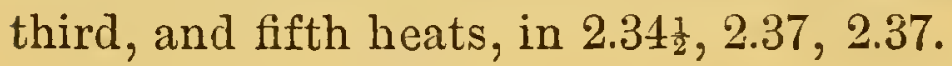

\section{EASTERN QUEEN.}

Black mare, 16 hands high, with no white marks, foaled in 1862, formerly owned by Daniel Wyman, of Dover, Me., got by the Leighton Horse, by Old Drew, dam, a dark bay mare, pedigree, unknown. Eastern Queen was afterwards taken to Boston, and Sept. 29, 1869, she won a race at Boston, in three straight heats, beating Thomas Jefferson, Penobscot Chief, Capt. Lawrence, General Sherman, Lady Lightfoot, Big Jim, and Jenny Spencer. Time $2.37 \frac{1}{2}, 2.33 \frac{1}{2} ; 2.33$. Oct. 21, 1869, at the Union Course, L. I., she beat Lady Wells, in straight heats, in $2.35 \frac{3}{4}, 2.36,2.36 \frac{3}{4}$. Afterwards owned by F. J. Nodine, Brooklyn, N. Y. In 1871, she foaled Richard, brown horse, by Nodine's Peacemaker, by Rysdyke's Hambletonian.

\section{BLACK WALNUT.}

Black gelding, foaled in 1860 , bred in Belfast, Me., or vicinity, got by Dirigo, dam, not traced. He was formerly owned by Harry Bradley, and finally, by Col. Bingham, of the Revere House, Boston. Aug. 31, 1869, at Dover, N. H., he beat Nellie Locke and Topsey, winning the third, fourth, and eighth heats in $2.31 \frac{1}{2}, 2.35,2.33$. 
July 4, 1870, at Rockland, Me., he beat McClellan in straight heats in $2.39 \frac{1}{4}, 2.34 \frac{1}{2}, 2.34 \frac{3}{4}$.

At Boston, Aug. 4 and 5, 1870, he beat McClellan, Fanny, and Empress, winning the third heat in $2.33 \frac{1}{2}$, the fifth in 2.36 , and the sixth, heat and race, in $2.32 \frac{1}{2}$.

Aug. 11, 1869, at Manchester, N. H., he won the second heat in a race in $2.30 \frac{1}{4}$, and was beaten in the race. This is his fastest public record.

\section{BANGOR.}

Formerly "Bully Brooks," bay gelding, 15 hands high, with star in forehead, stripe on nose, and off hind heel white, foaled in 1861, in Brooks, Me., got by Dirigo, dam, a roan mare, supposed to be of Messenger descent. . He is owned by Timothy Sullivan, Bangor, Me. July 5, 1869, at Bangor, Me., he beat Black John, Ottawa, and others, with a record of 2.42. July 29 , he beat Lady in straight heats at the same place. He is said to have a public record of $2.33 \frac{3}{4}$.

\section{HARD ROAD.}

Bay gelding, with black points, and no white, $15 \frac{1}{4}$ hands high, foaled in 1862, got by Dirigo. At Saco, Me., June 3, 1871, he beat Brown Nathan, and Black Ralph in straight heats, fastest $2.45 \frac{3}{4}$. July 4 , he beat Brown Nathan again in three heats, fastest 2.43. He is said to have a public record of 2.33 .

\section{EMPEROR.}

Spotted gelding, foaled in 1865, bred by William Trafton, St. Albans, Me., got by Joe Hooker, he by Spiritualist, he by Old Drew, dam, by Wildair, a horse imported 
from Canada. Emperor got a record of 2.42 as a fiveyear-old at Portland, and was afterwards sold together with his mate, Kit Carson, to Lon Morris, of Boston, for $\$ 2000$.

\section{KIT CARSON.}

Spotted gelding, foaled in 1866 , bred by William Trafton, St. Albans, Me., got by Gen. Sherman, by Old Drew, dam, (the dam of Emperor) by Wildair. Subsequently purchased by Lon Morris, of Boston.

\section{BAYARD.}

Blood bay gelding with black points, $15 \frac{1}{2}$ hands high, foaled in 1867, owned by A. W. Brackett, Pittsfield, Me., got by the Colbreth horse, by Hiram Drew, dam, the Capt. Adams mare (so called) of Morgan descent. In 1872, at Maine State Fair at Bangor, he won the race for horses that never beat 2.48 , the fastest heat being $2.40 \frac{1}{4}$, which he won. In 1873, at the Maine State Fair, also at Bangor, he won the race in the 2.40 class, in straight heats, beating a field of five horses in $2.45,2.47,2.40$.

\section{DETECTIVE.}

Brown gelding, $15 \frac{1}{4}$ hands high, foaled about 1856 , bred by Samuel Swett, Arrowsic, Me., got by Hiram Drew, dam, pedigree unknown. John Heald, of Portland, bought him in 1865, and afterwards sold him to Lon Morris, of Boston, Mass. Oct. 9, 1867, at Riverside Park, Boston, he obtained a record of 2.35. Oct. 2, 1868, at Boston, he beat Fanchon in 2.38 $\frac{1}{2}, 239 \frac{1}{4}, 2.44 \frac{1}{2}$. 


\section{CLOUDMAN.}

Chestnut gelding, $15 \frac{3}{4}$ hands high, foaled in 186-, bred by Nathan Cloudman, of Levant, Me., got by Hiram Drew, dam, of Messenger descent. Sold to Col. T. S. Lang, of Vassalboro. He is said to have trotted a mile in 2.28 in private, to a 128 pound wagon, with but little training.

\section{JOHNNY SCHMOKER.}

Gray gelding, $15 \frac{1}{2}$ hauds high, foaled about 1861, bred by a Mr. Quimby, of Mercer, got by a son of Old Drew. James Keegan, of Augusta, bought him of Mr. Quimby. He was afterwards purchased by Col. Bingham, of the Revere House, Boston.

\section{POLLY PERKINS.}

Mahogany bay mare, 15 hands high, foaled in 18-, formerly owned by A. W. Brackett, Pittsfield, Me., got by Old Drew, dam, a pacing mare, pedigree unknown. Brackett sold her to New York parties.

\section{GEORGIE B.}

Chestnut mare, 15 hands high, foaled in 1867 , bred by Alfred Brown, of Bowdoin, Me., got by Gen. Burnside, he by Gen. McClellan, dam, not traced. Sold in 1873 to Savage \& Nye, of Waterville.

\section{DECEITFUL.}

Brown mare, $15 \frac{1}{4}$ hands high, foaled in 1865, formerly owned by Letourneau Bros., of Waterville, Me., got by Dirigo. Sold to S. J. Vinal, of Boston, and by him to William Mason; of Taunton, Mass. 
MAINE GIRL.

Mahogany bay mare with white ankles behind, $14 \frac{3}{4}$ hands high, foaled in 1864, bred by Horace McKenney, of Monroe, Me., got by Dirigo. McKenney sold her when two years old to his brother, E. H. McKenney, of Biddeford; he afterwards sold a one-half interest to M. G. Palmer, of Portland. At the New England Fair of 1869, at Manchester, N. H., she won a race in a field of fourteen horses, in three straight heats, the fastest being $2.39 \frac{1}{2}$. In 1873, at the June Meeting of the Forest City Park, Portland, she won a race, two miles and repeat, in 5.31, 5.31, beating Meddlesome, Gentle Annie, etc. She died in Biddeford, Me., in July, 1873.

\section{YOUNG DIRIGO (Brooks').}

Brown colt with black points, foaled June 20, 1871, owned by Abner Brooks, Corinna, Me., got by Dirigo, dam, by Brown Harry.

\section{DRUID.}

Black colt, foaled July 14,1872 , bred by Gen. Wm. S. Tilton, Togus, Me., got by Don Juan, dam, May, by Gen. McClellan.

\section{ORPHAN BOY.}

Dark chestnut colt with black points, foaled June 20, 1868, owned by Selden A. Parkman, Palmyra, Me., got by John Bright, dam, of Morgan descent.

\section{DAN. STEVENS.}

Black colt, foaled in 1870 , owned by James Clark, Camden, Me., got by the Cooper horse, by Dirigo, dam, the 
James Clark mare (so called). Clark sold him to E. P. Mahoney, Searsmont, Me.

\section{DAVID QUIMBY.}

Bay stallion with black points, and star in forehead, foaled May 10, 1871, bred by R. F. Parkman, Kingsbury, Me., got by Dirigo, dam, Nellie Higgins of Morgan descent.

\section{CORINNA BOY.}

Bay colt with black points, 15 hands high, foaled June 10, 1870, owned by Albert N. Dorr, Corinna, Me., got by Dirigo, dam, by Penobscot Chief.

GEN. SCOTT.

Stallion, foaled in 1871, Drew on both sides, owned by Adelbert Kelley, Newburgh Centre, Me.

\section{MARTIN MCCLELLAN.}

Chestnut stallion, foaled June 6, 1859, owned by Martin Whittier, Montville, Me., got by the David Malcom horse of China, Me., he by Gen. McClellan, dam, French.

\section{EASTERN STAR.}

Black gelding, foaled April 17, 1870, bred by Gen. Wm. S. Tilton, Togus, Me., got by Pettingall's Young McClellan, dam, May, by Gen. McClellan.

\section{TROUBLESOME CRICKET.}

Dark bay gelding with black points, foaled May 25, 1870, bred by A. H. Parkman, Palmyra, Me., got by Dirigo, dam, of Morgan descent. 


\section{ALL TRUMPS.}

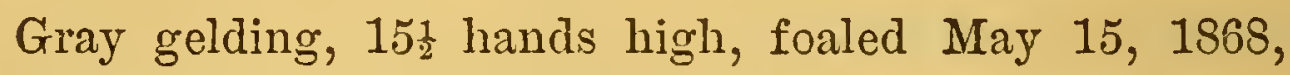
owned by A. G. Green, Newport, Me., got by Winthrop, by Old Drew, dam, a French mare.

\section{SILVERHEELS.}

Bay gelding with black mane and tail, star in forehead and white hind feet, over 15 hands high, owned by Henry E. Shorey, No. Vassalboro, Me., got by Dr. Paxton, dam, thoroughbred.

\section{NELLIE GRANT.}

Light sorrel filly, with star in forehead, and two white hind feet, foaled June 15, 1870, owned by Charles B. Dore, No. Hermon, Me., got by Gen. Grant, by Gen. McClellan, dam, a Hambletonian mare that had a record of 2.43 in Portland when four years old..

\section{BOTHERSOME.}

Bay filly with black points, foaled in May, 1870, owned by Alvin J. Jones, Fairfield Centre, Me., got by Trotting Blood, by Old Drew, dam, Brown Betsey, by Old Eaton.

\section{LADY ELLSWORTH.}

Gray mare, $15^{\frac{1}{2}}$ hands high, and weighs 950 pounds, foaled in 1869, bred by Warren Mills, Palmyra, Me., got by Winthrop (Green's), dam, by French Tiger. Lady Ellsworth is now owned by C. Shaw \& Son, Detroit, Me.

\section{NELLIE PALMER.}

Bay filly, foaled May 11, 1872, owned by A. F. Park- 
man, Garland, Me., got by Gen. Lyon, owned by Arnold Palmer, Palmyra, Me., dam, pedigree unknown.

\section{HUNTSMAN.}

Gray stallion, foaled 1870, in Newport, Me., the property of W. E. Greene, of Stockton, California, got by Gen. Lyon, owned by Arnold Palmer, Palmyra, Me., dam, the dam of Winthrop, by Old Eaton, 2d, dam, by Stone's Messenger.

\section{NETTIE.}

Bay filly with black points, strip in face, and one white hind foot, foaled May 4, 1873, bred by R. F. Parkman, Kingsbury, Me., got by Dirigo, dam, Nellie Higgins, by Black Morgan.

\section{BEULAH.}

Bay filly with black points, foaled in June, 1872, owned by C. D. Miller, Skowhegan, Me., got by Dirigo, dam, by the Beals horse.

\section{EASTERN BELLE.}

Chestnut filly, foaled in May, 1872, owned by R. Davis, Exeter Mills, Me., got by Dirigo, dam, of Messenger descent.

\section{LADY QUIMBY.}

Bay filly with black points, star in forehead and strip, foaled April 28, 1872, owned by F. E. Steward, Corinna, Me., got by Dirigo, dam, by Brown Harry. 


\section{FANNY DREW.}

Black mare, foaled in 1868, owned by A. S. Parker, Skowhegan, Me., got by Eastman horse by Old Drew, dam, by the Merrow horse.

\section{DOLARES.}

Brown filly, foaled. May, 1873, owned by Cairn Simpson, Alton, Me., got by Dirigo, dam, a flea-bitten gray mare, by Homan's Messenger.

\section{RED ROVER.}

Bay colt with black points, and star in the forehead, foaled April 29, 1872, owned by Israel Dearborn, Corinna, Me., got by Dirigo, dam, by Royal Oak (which see).

\section{FLEETFOOT.}

Brown colt with star in forehead, and rear hind ankle white, foaled May 12, 1872, owned by M. D. Leighton, Corinna, Me., got by Dirigo, dam, a mare of Messenger descent, known as the Dr. Day mare.

\section{DON QUIXOTE.}

Brown colt, with strip in face, and three white feet, foaled May 16, 1873, owned by C. T. Tewksbury, Corinna, Me., got by Dirigo, dam, the Dr. Day mare.

\section{EASTERN BOY.}

Bay colt with black points, and star in forehead, foaled in May, 1873, owned by F. W. Harmon, Corinna, Me., got by Dirigo, dam, by Independence, by Old Drew. 


\section{DIRIGO PRINCE.}

Black stallion with star in forehead, foaled June 10 , 1870, owned by Stephen Lincoln, Corinna, Me., got by Dirigo, dam, known as the "Thomas Andrews' mare."

\section{LITTLE CLYDE.}

Black colt with star in forehead, foaled June, 1871, owned by Stephen Lincoln, Corinna, Me., got by Dirigo, dam, the Thomas Andrews' mare.

\section{PET.}

Brown filly, foaled July 9, 1870, bred by W. F. Harmon, Corinna, Me., got by Dirigo, dam, by Independence, by Old Drew.

\section{LITTLE FRED.}

Brown colt, foaled May 12, 1872, bred by W. F. Harmon, Corinna, Me., got by Dirigo, dam, by Independence, by Old Drew.

\section{BLACKSMITH MAID.}

Bay filly with black points, near hind ankle white, and star in face, foaled June 3, 1872, bred by Samuel Forvles, Corinna, Me., got by Dirigo, dam, by Bessey horse.

\section{WILD PRAIRIE.}

Bay colt with black points, near hind ankle white, foaled May 29, 1871; bred by Wesley Burrill, Corinna, Me., got by Dirigo, dam, by Wild Prairie, a horse brought from Canada. 


\section{RISING SUN.}

- Bay colt with black points, star in forehead, foaled July 13, 1871, bred by Alden Wentworth, Corinna, Me., got by Dirigo, dam, pedigree, unknown.

\section{CAPT. ATWELL.}

Bay colt, foaled July 5, 1871, bred by J. P. Langley, Palmyra, Me., got by Dirigo, dam, by Merrow horse.

\section{MINEADA.}

Bay brown filly with black points, and white star in forehead, foaled May 22, 1873, bred by A. G. Greene, Newport, Me., got by Dirigo, dam, Cornelia, by the Titcomb horse, $2 \mathrm{~d}$ dam, by Old Eaton.

\section{FLYING GIPSEY.}

Dark chestnut filly, with stripe in face, and white hind feet, foaled April 16, 1869, owned by M. S. Fuller, Winslow, Me., got by the G. E. Shores horse, by Hiram Drew or Reindeer, dam, a Rising Sun.

\section{MAYFLOWER.}

Filly, foaled May 1, 1870, bred by S. C. Ryder, No. Bradford, Me., got by Red Jacket (?) dam, Black Hawk.

\section{LADY MAC.}

Chestnut filly with black points, foaled July 15, 1871, owned by A. S. Drummond, Arrowsic, Me., got by Young Mac, by Gen. McClellan, dam, by Arabian Hunter. 


\section{MAGGIE QUIMBY.}

Brown filly, foaled April 30,1872, bred by D. C. Lyford, Corinna, Me., got by Dirigo, dam, Nellie, by Young Eaton.

\section{NELLIE DREW.}

Bay mare, foaled in 1869, owned by G. B. Pillsbury, Unity, Me., got by young Hiram Drew, dam, a Drew mare.

\section{LADY BELLE.}

Dark bay mare, foaled in 1869 , owned by G. B. Pillsbury, Unity, Me., got by young Hiram Drew, dam, a Drew mare.

\section{GIPSEY MAID.}

Bay mare, with star in forehead, and two white fore feet, foaled April 29, 1869, bred by William Smith, East Exeter, Me., got by Gen. Grant, by Gen. McClellan, dam, pedigree unknown.

\section{GIPSEY GIRL.}

Mare, foaled in 1868, owned by S. W. Thompson, Bowdoinham, Me., got by Silver Cloud, by Gen. McClellan, dam, Drew and Messenger.

\section{INDEPENDENCE.}

Sorrel gelding with star in forehead, foaled in June, 1869, owned by John C. Pillsbury, Palmyra, Me., got by Winthrop, by Old Drew, dam, of Morgan descent. 


\section{BAY BEAUTY.}

Dark bay filly with black points, foaled in June, 1870 , owned by John C. Pillsbury, Palmyra, Me., got by Winthrop, by Old Drew, dam, of Morgan descent.

\section{SLIPPERY SALLY.}

Dark bay mare with star in forehead, 15 hands high, owned by Jonathan Bates, Fairfield Centre, Me., got by Don Juan, by Old Drew, dam, of Morgan descent. 


\section{EATON STOCK.}

\section{EATON HORSE.}

The originator of the breed of horses known as the "Eaton" was a sorrel stailion, with mane and tail the same color, and a narrow white stripe in the face, $16 \frac{1}{2}$ hands high, and weighed 1450 pounds; foaled in 1842, bred by Thomas Pelton, of Anson, near Madison Bridge, got by the Avery horse (which see), dam, the Pelton mare (so called), said to be by Winthrop Messenger.

Pelton sold him when two years old to E. D. Robinson, of Wilton; he let Caleb Jones, also of Wilton, have him, and Jones kept him one year and then sold him back to Mr. Robinson. He was afterwards sold to Eliab L. Eaton, then of Farmington, and became known as the Eaton horse. Mr. Eaton sold him in 1854 to William Beal, of Winthrop, who kept him four years and sold him in 1858 to parties in Nashville, Tennessee. We have no knowledge of his subsequent history.

\section{BEALS' HORSE.}

Chestnut stallion with star in forehead, 16 hands high, and weighed 1125 pounds, foaled in 1848 , bred by Daniel Beals, of Farmington, Me., got by Old Eaton, dam, not traced. Mr. Beals kept him until he was about twenty 
years of age, when he sold him, and he died in Farmington in 1872.

\section{MT. VERNON.}

Sorrel stallion, with small white strip in face, and one white hind foot, 16 hands high, and weighed 1150 pounds, foaled in 1853, bred by Elisha Wells, of Mt. Vernon, Me., got by Old Eaton, dam, pedigree not traced. Wells sold him to George Wakefield, of West Gardiner, and he to Oliver Waiton, of Boston, Mass. He was afterwards taken to Philadelphia, where he is said to have trotted fast.

\section{KENNEBEC MESSENGER (BEALS').}

Sorrel stallion, with star in the forehead, 16 hands high, and weighed 1100 pounds, foaled in 1846, bred in Strong, Me., got by Old Eaton, dam, of Messenger descent. Mr. Edward Bomney, of Winthrop, bought him when three years old, and sold him when four to Mr. William Beals, of Winthrop. He'was afterwards sold and taken into the eastern part of the State or into the Provinces.

\section{SANDY RIVER HORSE.}

Sometimes called the "Sandy River Trotter,"-chestnut stallion, with strip in face, and white hind foot, $15 \frac{1}{4}$ hands high, foaled in 1852, bred by Hiram Bent, of Vienna, Me., got by Old Eaton, dam, a Morgan mare. Bent sold him when three years old to James Allen, of Farmington, Me.

\section{BENNETT HORSE.}

Black stallion, with star in the forehead, and white hind feet, $15 \frac{1}{2}$ hands high, and weighed about 1,000 
pounds, foaled in 1851, bred by Hiram Stoyell, of Farmington, Me., got by Old Eaton, dam, a spotted mare, owned by Mr. Stoyell, and said to be of Arabian blood. Stoyell sold him when young to Dr. Prescott, of Farmington, he let his son, Josiah Prescott, of Phillips, have him, and he sold him to Mr. Bennett. He died in Freeman, Me., in December, 1871.

\section{RED CLOUD.}

Sometimes called the "Stevens Horse," dark sorrel stallion, with white stripe in face, $15_{\frac{1}{2}}^{\frac{1}{2}}$ hands high, and weighs 1120 pounds, foaled in 1855 , bred by Paul $T$. Stevens, of Sidney, Me., got by Old Eaton, dam, by the Tolman horse, grand dam, by the Lovejoy horse.

\section{OAKS HORSE.}

Sorrel stallion, with white stripe in face, $15_{\frac{1}{2}}$ hands high, foaled in 1852, bred by Gardiner Drake, of Farmington, Me., got by Old Eaton, dam, said to be of Morgan descent. Drake sold him when two years old to David Oaks, who kept him until 1872, when he was sold to J. P. Norton, of Lewiston, Me. He was never harnessed until Oaks sold him.

\section{BRIGIAM YOUNG.}

Black stallion, with white hind feet, $15 \frac{3}{4}$ hands high, and weighs about 1100 pounds, foaled. in 1866, bred by H. H. Hutchins, Kingfield, Me., got by the Bennett Horse, dam, of Messenger descent. Hutchins sold him in 1873 , to H. F. Harvey, of New Portland. 
GEN. GARIBALDI.

Black stallion, with star in forehead, and three white feet, foaled in 1868, bred by Rollo S. Sampson, Temple, Me., got by the Beunett Horse, dam, by Morgan Bennett.

\section{ROMAN EATON.}

Dark sorrel stallion, $16 \frac{1}{2}$ hands high, and weighs 1350 pounds, foaled in 1857 , bred by William S. Whittier, of Rome, Me., got by Old Eaton, dam, not traced. Owned by L. H. \& S. P. Hayden, Brighton, Me.

\section{BLACK MORGAN.}

Black stallion, $16 \frac{1}{4}$ hands high, and weighs 1160 pounds, foaled in 1857, owned by L. C. Leadbetter, Wayne, Me., got by Old Eaton, dam, by Black Morgan.

\section{BLACK STRANGER.}

Dark brown or black stallion, weighing 1080 pounds, foaled in 1868, bred by William Whittier, Rome, Me., got by Roman Eaton, dam, an English mare.

\section{GENERAL DIX (FISH'S).}

Black stallion, 16 hands high, and weighs 1075 pounds, foaled in 1866, owned by Andrew L. and N. W. Fish, Starks, Me., got by Patrick Henry, he by Old Eaton, dam, by the Crawford horse.

\section{TROUBLESOME.}

Mahogany bay stallion, weighing 1100 pounds, foaled in 1864, bred in Industry, Me., got by a son of Old Eaton, 
dam, of Morgan descent. Owned by Abner Toothaker, Phillips, Me.

\section{PARKER'S MESSENGER.}

Mahogany bay stallion, $15 \frac{1}{2}$ hands high, and weighs 1050 pounds, foaled in 1864, owned by Ingerson Parker, Greene, Me., got by the Stinchfield horse, by Old Eaton, dam, by Kentucky Hunter.

\section{SHEPHERD F. KNAPP.}

Sorrel stallion with white star in the forehead, and white hind feet, $15 \frac{1}{2}$ hands high, foaled in 1857 , bred by George Snell, of Turner, Me., got by Old Eaton, dam, by Whalebone. Snell sold him when a weanling to Silas Mitchell, of Buckfield. Mitchell kept him until he was two years old, and sold him in August, 1859, to the Russell Bros., for $\$ 200$. In 1860 , when three years old, he stood for service a part of the season in the vicinity of Buckfield, and got a few colts, among which were Shepherd Knapp, Jr., and the sorrel mare, Caoutchouc. Before the season closed, he was sold to Mr. Emery, of Portland. He afterwards went to New York into the hands of Mr. Genet. When four years old, he was trained, and trotted a very severe race of tive heats, losing the first two, and winning the three subsequent ones, the best of them being 2.41. The next year, while in training for a race with Harry Clay, he continually hit himself in the elbows, by reason of excessive knee-action as it appeared, and this prevented the bringing of him up to the mark. He was afterwards sold to Mr. Senter, and taken to England. In 1864, he was matched to trot two miles and a half with a horse called Express for $\$ 1000$ a side, the race to come off at the Bois de Boulogne near 
Paris, France, on the 31st of January, 1865. Express was an American, also, and was owned by a French gentleman at Rouen, in Normandy. The race was won by Shepherd F. Knapp in 6.14, being a trifle better than 2.30 to the mile. In 1836, much excitement was caused in sporting circles on the announcement that a great International match had been entered into between two horses, the representatives of England and France, in which $£ 600$ were deposited. The horse chosen as the representative of France was Abdallah King, an American, while Shepherd F. Knapp was selected as the champion of England. Abdallah King was trained at Paris, while Knapp went through the "grand preparation" at Ealing, and only took a trip across the Channel on the Friday preceding the race, which took place at the Cascade, on the Bois de Boulogne, Paris, on Monday, Feb. 12, 1866. The distance was one mile in harness. The elite of the Parisian sporting world were present, although the race as it turned out, was a hollow affair. Knapp literally "walked in," and won as he liked by nearly fifty yards.

\section{SHEPHERD KNAPP, JR.}

Bay gelding, with narrow white stripe in face, spot on under lip, two white stockings forward and one behind, with white hairs mixed in all over his body, about $15 \frac{1}{4}$ hands high, foaled in 1861, bred by John E. Bonney, Turner, Me., got by Shepherd F. Knapp, dam, by Royal Oak (which see). Bonney sold him when a sucking colt to the Russell Bros., of Buckfield. He was originally a pacer, and followed that way of going until he was four years old,. when he left it for a better one, and commenced to trot fast. He made his first appearance in 
public at the Maine State Fair of 1866 at Augusta, Me., where he won the five year old purse and a record of 2.36 . At that time he wore forward shoes weighing $2 \frac{1}{4}$ pounds each. He was then sold to George M. Delaney, of Auguista, for $\$ 3,250$, and went into the stable of George $\mathrm{H}$. Bailey, the well-known trainer. His first race in $\mathrm{Mr}$. Bailey's hands was at Augusta in Oct., 1866, when he beat Emperor and Johnny Schmoker. Nov. 1, same year, he met and defeated, in straight heats, the stallion Draco Prince, and the celebrated twenty-miler, John Stewart, over the Mystic Park, Boston. The time of the heats were $2.33,2.33 \frac{1}{2}, 2.36$, and in the third heat Knapp gave a taste of his quality by trotting a quarter in $33 \frac{1}{2}$ seconds. The next season, 1867, Mr. Bailey had Knapp in training at Riverside Park, Boston, where he was very successful. While owned by Mr. Delaney he trotted fourteen races, and won eleven.

He was sold that fall to Charles O. Conant, of Boston, fol $\$ 6,500$, and trained by the late William Woodruff. The next season, 1868, he was sold to Dr. Page, of Boston, his present owner, who paid $\$ 10,000$ for him. May 27, 1869, at the Prospect Park, he beat Old Put, Darkness, Com. Nutt, Western New York, and Surprise, in straigint heats, for a purse of $\$ 3000$; time, 2.30, 2.30굴, 2.34. June 7, same year, he beat the black stallion Darkness in three straight heats to wagon, for $\$ 2000$. The race was at the Riverside Park, Boston, and Knapp won in $2.33,2.30 \frac{1}{2}, 2.29 \frac{1}{2}$, which is his fastest public record. He has since passed through the hands of several of the most prominent Boston trainers, and has been trotted all over the country, but has been very unsuccessful until the past season. In July, 1873, he was returned to $\mathrm{Mr}$. 
Bailey, his old trainer, in hopes that the same treatment he had formerly given him might produce the same results, and that he might be able to turn the tables upon those horses that have been defeating him for the past five years, by again appearing in public as a winner. The result, while it is very flattering to Mr. Bailey's skill as a patient, careful, and intelligent handler of the trotting horse, must be also very gratifying to the friends of the little white-legged Knapp, who have stuck to him through so many adversities. He started in ten races last fall, and won nine of them, receiving one forfeit, having lost but one race through the fall campaign.

At Waterville; Me., July 25, he beat Gen. Lightfoot, Red Jacket, White Stockings, Little Ed, Pomp, and Amazon; best time, 2.37. Lewiston Driving Park, Aug. 29, received forfeit from White Stockings in a match for $\$ 500$. Same track, Aug. 30, match for $\$ 500$, he beat Buf-

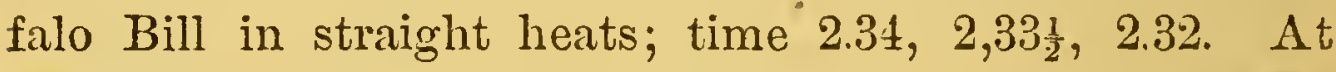
Maine State Fair at Bangor, Sept. 10, he won the Sweepstakes purse, beating the stallion Gen. Lightfoot, and the St. John's horse, Andy Johnson. The time was 2.41, 2.35, $2.35,2.37,2.44 \frac{1}{2}$. Andy Johnson won the first two heats, and the last was trotted in a gale of wind and rain. In Sept., at the Forest City Park, Portland, he won tlre "free for all " purse of $\$ 400$, beating Buffalo Bill; best time, 2.36. In the last heat of this race, Knapp, by a bad break, fell several lengths behind, but getting steadied as he reached the three-quarter pole, he trotted the last quarter in the remarkable time of 30 seconds, winning the heat and race. At Taunton, Mass., Bristol County Fair, Oct. 2, he won the "free for all" purse of $\$ 700$, beating Billy Platter and Climax; time $2.33 \frac{1}{4}, 2.34 \frac{1}{2}, 2.34 \frac{3}{4}$, 2.36; Platter winning the second heat. At Beaccn Park, 
Boston, Oct. 11, he beat Fannie, Bristol Bill, and Joe

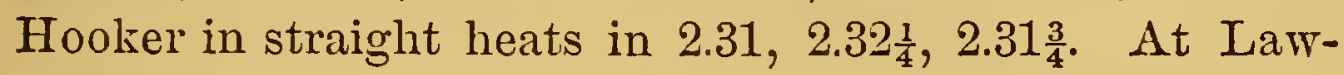
rence, Mass., Oct. 24, he won the last three out of five heats in the 2.29 purse in $2.36 \frac{1}{4}, 2.34 \frac{1}{2}, 2.35 \frac{i}{4}$, beating Fannie, Bristol Bill, Frank Palmer, and Ki-Ki. At Manchester, N. H., Oct. 30, he again beat Frank Palmer, Ki-Ki, Bristol Bill, and Ned Wallace. This was his last appearance in 1873.

\section{GRAY STRANGER.}

Gray gelding, $15 \frac{3}{4}$ hands high, foaled about 1850 , bred by Monroe Woodman, of Wilton, Me., got by Old Eaton, dam, of Messenger descent. Charles Milliken, Esq., of Augusta, bought him in Farmington, and took him to Augusta. He was subsequently owned by George M. Robinson, who sold him in 1861 to Andrew Banner, of Philadelphia, $\mathrm{Pa}$.

July 4, 1855, as Stranger, he trotted in a race at Bangor against Lady Litchfield and Bay Morgan (afterwards Hiram Drew), and although beaten in the race, Stranger won the third heat in 2.30 and the fourth in 2.33 .

\section{CAOUTCHOUC.}

-Sorrel mare, $15_{\frac{1}{2}}^{1}$ hands high, and weighs 975 pounds, foaled in 1861, bred by Orville Bridgham, Buckfield, Maine, got by Shepard F. Knapp, dam, Witherell. She was sold to Irving Blake, of Portland, and he sold her to H. A. Hall, of Boston, in 1871, for $\$ 2,000$.

At the New England Fair at Lowell, Mass., Sept. 5, 1872, she won the race for horses that never beat three minutes, in a field of twelve, in straight heats. Time 2.$41 \frac{1}{2}, 2.41 \frac{3}{4}, 2.41 \frac{1}{4}$. At the New England Fair of 1873, at 
the Mystic Park, Boston, in the 2.40 race, she won the second heat easily, with a record of $2.35 \frac{1}{2}$.

\section{DANIEL BOONE.}

Sorrel gelding, with white star in the forehead, $16 \frac{1}{2}$ hands high, foaled in 1863, bred by Oliver Dunnell, North Jay, Me., got by the Beals Horse, by Eaton, dam, a bay mare, owned by Mr. Dunnel, pedigree, unknown. Dunnell sold him to John Look, and after having several different owners, Mr. K. Larkin, of Farmington, bought him. He sold him in 1872, to Charles G. Sterns, of Bangor. At Forest City Driving Park, Portland, Me., Aug. 30,1871 , he beat Hector and Honest Shaker, in straight heats, in $2.46 \frac{1}{2}, 2.45,2.46$. June 26,1873 , in a race at Bangor, Me., he won the first heat, 2.39, but we think he has a faster record than even this, in an unpublished race.

\section{WHAT IS IT.}

Chestnut gelding, 15 $5_{4}^{\frac{3}{4}}$ hands high, foaled in 185-, bred by Samuel Daggett, Farmington, Me., got by the Beals Horse, by Eaton, dam, by Witherell. He was purchased by C. G. Jackson, of Winthrop, who sold him to Abner Barrows, of New York. Oct. 4, 1864, at Fashion Course, L. I., he beat Shot and Lady Winthrop, in $2.35 \frac{3}{4}, 2.36$, 2.$3 S$.

\section{VILLAGE MAID.}

Formerly "Lady Norton," bay mare, with black points, $15 \frac{3}{4}$ hands high, and weighed about 1100 pounds, foaled in 1852 or 3 , bred by Harrison Norton, Farmington, Me., got by Old Eaton, dam, not traced. Norton sold her when eight or nine years old to McKeever, of New York, who was afterwards killed at Chicago, while 
driving against Cooley. May 19, 1864, at the Union Course, L. I., in a race, against Lady Clifton for a purse of $\$ 1,000$, she obtained a record of 2.35 , in the first heat.

\section{LADY BRADFORD.}

Blood bay mare, with black points, diamond in forehead, and one white hind foot, owned by John H. May, Augusta, Me., got by Young Dud, by Old Eaton, dam, by Old Drew.

\section{ROSE OF SHARON.}

Bay mare, with black points, 15 hands high, foaled in 185s, bred by H. B. Prescett, New Sharon, Me., got by Old Eaton, dam, pedigree, unknown. Prescott sold her and she was carried to Massachusetts, and trotted at the Mystic Track, obtaining a record of 2.34 .

\section{NELLIE BURTON.}

Bay filly, with black points, and star in forehead, foaled Oct. 11, 1870, bred by A. J. Lyon, West Waterville, Me., got by Red Cloud, dam, by an imported horse.

\section{NELLIE MORRILL.}

Black filly, foaled in May, 1871, bred by Charles $\mathrm{H}$. Morrill, Athens, Me., got by Roman Eaton, by Old Eaton, dam, pedigree, unknown.

\section{COPPER BOTTOM.}

Black gelding, with narrow white stripe in face, $15 \frac{1}{2}$ hands high, foaled in 1867, bred by W. H. Perkins, of Farmington, Me., got by the Hiram Norton horse, by Old Eaton, dam, of Morgan descent. Perkins sold him in 1873 , to N. C. Hutchins, North Chesterville, Me, and he got a record of $2: 45$, at Norway. 


\section{RISING SUN STOCK.}

\section{RISING SUN.}

Light bay stallion, with star in the forehead, and black mane and tail, 15: hands high, and weighed adout 1000 pounds, foalea in 1843, bred by Eben Young, of Peru, Me., got by a dark bay stallion, with black points, under 15 hands high, called Rising Sun, who was brought into Canton, Me., in January, 1812, from Calais, by a Mr. Griffeth. He was owned by a Mr. Gilman, wha was in the Legislature, and his son-in-law, Mr. Griffeth took him to Canton to winter. He was said at that time to be, by an imported thoroughbred horse, and out of a French mare. In March following, Messrs. G. \& C. Hayford, of Canton, bought him for $\$ 150$, and stood him in that vicinity during the season of 1842. He died at Canton of lung fever, April 27, 1843.

The dam of Rising Sun was a bay mare owned by $\mathrm{Mr}$. Young, noted for her breeding qualities, got by Duroc, a white stallion, brought from Long Island, about 45 years ago, by Bennett Pompilly, of Turner, Me. He (Duroc) was a noted running horse and ran many races, and was well known throughout the State. He possessed many of the characteristics of the thoroughbred, and was said to be by a horse called Duroc, but how related to Duroc by Imported Diemed, we are unable to say. Mr. 
Young sold Rising Sun to G. \& C. Hayford, when four months old, and they kept him until the fall after he was two, and sold him to Maj. Isaac Strickland, of Livermore. Strickland sold him in 1848, when five years old, to Gideon Ellis, Jr., of Canton. Mr. Ellis sold him, and after passing through several different hands, he again became his property. He was finally bought by Grant \& Milliken, of Farmingdale, and afterwards taken to Massachusetts, where he was kept for stock purposes for two or three years. From Massachusetts, he was brought back to Waterville, Me., and owned awhile by a Mr. Rounds. Here he was found by a son of Maj. Strickland, who bought him and brought him back to Livermore. He was afterwards sold, and died in Carthage, Franklin County, in 1867.

\section{ROLLINS HORSE.}

Black stallion, with small star and white hind feet, about $15 \frac{3}{4}$ hands high, foaled in 1852 , bred by Frederic Ellis, of Carthage, Me., got by Rising Sun, dam, a medum sized bay mare of French or Morgan descent. Ellis sold him while young to B. R. Rollins, of Weld, and he kept him several year's and sold him to Tuttle \& Hobbs, of Bryant's Pond, Me. They afterwards sold him, and he died in 1864 or' ' 65 . He was a good trotter in his day.

\section{YOUNG TOBIN.}

Bay stallion with black points, 15 hands high, and weighed about 900 pounds, foaled in 1856 , bred by Oren Reynolds, Canton, Me., got by Rising Sun, dam, a chestnut mare bred by Mr. Reynolds out of a Morgan mare brought from Vermont. 
Mr. Samuel Tobin, then of Hartford, Me., bought him in the fall of 1856, and he was always called the Young Tobin to distinguish him from another stallion owned by Mr. Tobin at the same time, and called the Tobin horse.

He was kept for service in Canton and vicinity until seven years old, and then sold to Farrai \& Morrill, of Buckfield. He stood one or two seasons in Buckfield, and was then taken to Massachusetts. When his stock came into use, they were thought so well of that $\mathrm{Mr}$. O. T. Bosworth, of Canton, a gentleman who always took a great interest in horse matters, went to Massachusetts, and spent some time in trying to find him, but was unable to learn anything concerning his subsequent history.

\section{YOUNG AMERICA.}

Dark brown stallion, $15_{\frac{1}{2}}$ hands high, and weighs 1000 pounds, foaled in 1868, bred by Isaac Dunbon, Burnham, Me., got by a son of Rising Sun, dam, Drew and Black Hawk.

\section{BLACK DAN.}

Black stallion, with star in face, $15 \frac{1}{4}$ hands high, and weighs 950 pounds, foaled in 1865, owned by O. C. and S. D. Houghton, Bryant's Pond, Me., got by the Newman horse, he by the Rollins horse, dam by Lewiston Boy.

\section{PAT.}

White stallion, 16 hands high, and weighs 1200 pounds, foaled in 1863, raised in Penobscot county, owned by G. M. Blake, Monmouth, Me., got by Rising Sun, dam by Gray Eagle. 


\section{TAMMANY.}

Light gray gelding, $15 \frac{3}{4}$ hands high, foaled in 1864, formerly owned by Daniel M. Atherton, Houlton, Aroostook county, Me., "got by a bay stallion with black points, with deep shoulders, high withers and large stifles, showing good breeding in every point." He was said to be by Rising Sun, and is now running on a stage team in Piscataquis county. The dam of Tammany was a gray, inbred, Messenger mare, got by Warrior, he by Young Winthorp Messenger, by Winthrop Messenger. Tammany resembies his dam in color, and his sire in form and general characteristics. He was afterwards owned by $\mathrm{C}$. F. Jordan, of Oldtown, and when seven years old he got a record of 2.27 in a race at Bangor. He was afterwards sold to H. N. Smith, of New York. Warrior, the sire of the dam of Tammany, was also the sire of Lady Messenger, the dam of Crown Prince (record 2.25), Gray Chester, etc.

\section{NABOCKLISH.}

Afterwards called John MicKinney, was a dark brown gelding, with narrow white stripe in the face, and white stockings behind; standing 15 hands, 3 inchès high, foaled about 1852, bred by Osborn Baker, Carthage, Me., got by Rising Sun, dam, a black mare with white stripe in the face, pedigree unknown. Baker sold him, when one year old, to Hiram Coburn, of Carthage. Coburn sold him, and after passing through several hands, he become the property of Isaiah Pompilly, of Auburn. He sold him to Samuel Perley, of Brettun's Mills, Livermore, when five years old, and Perley took him to Illinois in 1858 or 1859. 
He became very famous, and made his mark on all the Western and Southern trotting tracks, from Cincinnati to New Orleans. Among his performances were the following: In 1864, at Cincinnati, Aug. 16, he won a race and a record of $2.29 \frac{1}{2}$, beating Harry Clay and Brown Dick.

At the Illinois State Fair, in 1865, Sept. 9th, in a race with Cooley, Lady Walker and Quaker Boy, Nabocklish won the second heat in $2.29 \frac{3}{4}$.

In 1869, Aug. 13, at Buffalo, N. Y., he trotted a double team race with Medoc against Kitty and Belle Collins, in which the mares were distanced in the first heat.

All who have read "Horse Portraiture," by Joseph Cairn Simpson, and most horsemen have read it, have no doubt been much interested in the history and performances of the horse "Never Mind." This horse and Nabocklish are believed to be one and the same.

\section{EMPEROR.}

Bay gelding with black points, 14 hands high, and weighed, in trotting condition, 725 pounds, foaled in 1860 , bred by Levi Gardner, of Plantation No. 4, Franklin county, got by the Rollins Horse, by Rising Sun, dam, a small mare "got by a Messenger horse owned in Somerset county."

Gardner sold him young, and after having several owners he became, at five years of age, the property of Mr. Albert Foster, of Canton Point, Me. He was at that time a pacer. Mr. Foster got him in the Spring, and the following Fall he let Granville Childs, also of Canton Point, have him.

While owned by Mr. Childs he commenced to trot, and improved right along, and when six years old he sold him to Charles Records, of Mass, and Isaiah Pompilly, of 
Auburn, Me., for $\$ \$ 50$. At that time he was considered very fast. At Portland, Oct. 10, 1866, he won a race, the fastest heat being $2.39 \frac{1}{2}$. The next day, Oct. 11, he beat Shepherd Knapp, Jr., and Dashaway, and got a record of 2.37. In 1868, Ott. 6, at Boston, in a race against Warwick and Madawaska Maid, he won the first heat in 2.34. Oct. 14, 1868, at the Narragansett Park, R. I., in a race against $W$. $H$. Taylor and eight others, Duchess

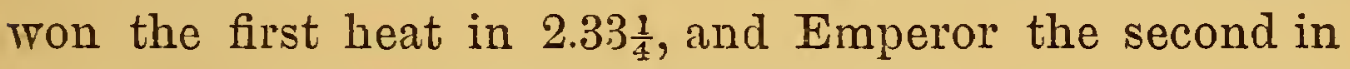
2.30 , and the third in 2.32 , and was distanced in the fourth heat, the race being won by W. H. Taylor.

\section{LADY FAIRFIELD.}

Gray mare, 15 hands $3 \frac{1}{2}$ inches high, and weighs 960 pounds, in trotting condition, foaled in 1862 , bred by Frank Wing, of Fairfield, got by Rising Sun, dam, a gray mare of Messenger descent, known as the Frank Wing mare. Wing sold her when one year old to W. \& W. Jones, of Fairfield; they sold her to J. S. Gifford, and he sold her when three years old to Rodney Jones for $\$ 175$. Jones sold her to E. K. Russell \& Co., of Madison, when four year's old for $\$ 600$, and Hill \& Emery, of Slowhegan, bought her of them for $\$ 1750$. She was afterward sold to J. D. Walton, of New York, for $\$ 2000$, and the last known of her she was owned by ex-Sheriff O'Brien, of New York city. She trotted several races while owned in this State. Three days from the pasture, she won the four-year-old purse at Skowhegan, with a record of 2.54. The 5th of July, 1867, when five years old, at Augusta, she won the five-year-old purse, time, 2.44. July 4th, 1868 , she won a race at Hartland, beating Lady Hamilton with a record of 2.34. At Water- 
ville, Aug. 24, 1870, she won a race, beating. Lady Burleigh in three straight heats in $2.37 \frac{1}{2}, 2.38,2.39$. At the County Fair at Skowhegan, the same season, she won a race, beating Sleepy David in 2.36. At Dover, in Sept., she beat Sleepy David, Abdallah, etc., jogging home in 2.37. At the State Fair, same season, she was awarded the first prize, but did not trot as no horse would contend with her.

\section{CARTHAGE BOY.}

Dark brown gelding, $15 \frac{1}{2}$ hands high, with curly black mane and tail, foaled in 1862, bred by Oliver Newman, Carthage, Me, got by the Rollins Horse, dam, a black pacing mare, by Whalebone. Mr. Newman sold him when young, and after having several different owners he became, at five years of age, the property of Robert Potter, then of Portland.

Aug. 20,1870, at Skowhegan, he won a race, beating Bully Brooks, Beauregard, and Cushnoc, the fastest heat being 2.39. Oct. 22, 1872, at Mystic Park, Boston, he won a race, in three straight heats, beating Highland Maid, Lady Wentworth, Lady Morris, and Captain. Time 2.$32 \frac{1}{2}, 2.34 \frac{1}{2}, 2.35 \frac{1}{4}$. Mr. Potter sold him in 1872, to Mr. Roberts, of Charlestown, Mass.

\section{SALLY-COME-UP.}

Brown mare, $15 \frac{1}{4}$ hands high, foaled in 1856 , got by Rising Sun. Ira Kilgore, of Farmington, bought her in Kingfield when four years old, and sold her to Isaac Merrill, of Cumberland. Merrill sold her to James Howes, of New Sharon. He to William Gale, of North Anson. He to Charles Emery, of Skowhegan, and he to William 
Briggs, of Taunton, Mass. At Waterville, Me., she trotted in a race, getting a record in the thirties.

\section{LADY BERRY.}

Gray mare, 15 hands high, foaled in 1855 , bred by Capt. Rolf, of Rumford, Me., got by Rising Sun, dam, of Messenger descent. Rolf sold her to Albert Hines, then of Dixfield, when three years old, and Hines sold her to Mr. Emery, of Skowhegan.

Aug. 7,1866 , she won a race, at Augusta, Me., beating Croton Oil, California Joe, and Mt. Vernon, and obtaining a record of 2.39. She was afterwards taken to Massachusetts, and is said to be the dam of the gray gelding Hopeful (record 2.25), by Godfrey's Geo. M. Patchen, Jr.

\section{MOCKING BIRD.}

Bay gelding with black points, $14 \frac{3}{4}$ hands high, foaled in 1860, bred by Norman S. Beals, of Canton, Me., got by Young Tobin, by Rising Sun, dam, a French mare brought from Canada.

Beals sold him when four years old to John P. Swasey, of Canton, and he shortly afterwards to Samuel Burbank. Burbank sold him when five to Isaiah Pompilly, of Auburn. Sept. 20,1867, at Boston, he obtained a record of 2.40 in a race against Kangaroo, and Sept. 24, he won a heat in $2.40 \frac{1}{2}$ at the same place.

\section{REVENUE.}

Brown gelding, with star in the forehead, and one white hind foot, foaled in 1863, bred by Isaac Heath, Sumner, Me., got by Young Tobin, by Rising Sun, dam, by Young Brandywine. 
Heath sold him when five years old to Jesse S. Lyford, of Lewiston, and he sold him the next year to O. N. Cutler, of New York. This horse gained considerable notoriety in this State as the subject of a law suit of Lyford vs. Cutler. Lyford paid Mr. Heath over two thousand dollars for him, and during the trial it came out that the money was used to lift a mortgage from the farm the colt was raised on; that but for him would probably have been there now.

\section{BUCHANAN.}

Chestnut gelding, $15 \frac{3}{4}$ hands high, foaled in 1847 or ' 48 , bred by Cyrus Swift, Wayne, Me., got by Rising Sun.

Swift sold him to William Beal, of Winthrop, he to James Jack, of Portland, and he was afterwards taken to New York.

\section{GEN. SHERMAN.}

Bay gelding, about 16 hands high, with star in forehead, formerly owned in Portland by George Babcock, and called the Babcock colt. He was a noted road horse, and trotted several matched races on the road. Got by Rising Sun. He was afterwards taken to Massachusetts, and called Gen. Sherman, and trotted in the "forties." 


\section{FIYING EATON STOCK.}

\section{FLYING EATON.}

Bay stallion, with black mane and tail, and two white hind feet, with a few white hairs in forehead, making a faint star, $15 \frac{1}{4}$ hands high, and weighs about 1000 pounds, foaled in 1850, bred by Joseph Whittemore, Phillips, Me., said to be by Old Eaton; although this is denied by many; dam, a gray mare, said to be of Morgan descent. Whittemore sold him when a weanling to Joshua Parker, of Phillips; he sold him when three years old, to James Towle, also of Phillips.

After having several different owners, he was purchased in 1866, and brought to Farmington, Me., by Dana Goff, then of Farmington. Goff sold him to Samuel Farmer, the proprietor of the Barden House, Phillips, Me.

\section{FLYING EATON, JR.}

Dark bay stallion, with black points, and small star, $15 \frac{1}{2}$ hands high, and weighs 1000 pounds, foaled in 1865, bred by Mr. Collins, of Kingfield, Me, got by Flying Eaton, dam, pedigree, unknown. Dana Goff bought him when five years old, and took him to Farmington. In 1872, Goff sold him to Sewall Goff, of Mexico, Me. 
SHOOTING STAR.

Bay stallion with black points; $15 \frac{1}{2}$ hands high, foaled in 1856, bred by Henry Carvill, then of Freeman, Me., got by Flying Eaton.

\section{SHARON.}

Chestnut stallion, foaled in 1869 , bred by Horatio $G$. Eaton, Farmington, Me., got by Flying Eaton; dam, an Eaton mare. Sold to S. N. Putnam, Santa Clara, Cal.

\section{JOHN FRANKIIN.}

Bay gelding, with black points, and one white hind foot, $15 \frac{1}{2}$ hands high, foaled in 1865, bred by Joseph Bangs, of Salem, Me., got by Flying Eaton, dam, of Messenger descent.

Bangs sold him, when three years old, to Charles Carvill, of Farmington, he, when four, to Samuel Farmer, who afterwards sold him to Bradford \& Sawyer, of Hyde Park, Mass., retaining a one-third interest. Sept. 9th, 1869, at Portland, Me., he won a race for four-year olds, beating Uncle Abe, now called Glengary, and Violetta, the fastest heat being 2.49 .

Sept. 11th, 1873, at Lawrence, Mass., he won the first and second heats in a race in $2.35-2.37 \frac{3}{4}$.

\section{TOM PARKER.}

Sorrel gelding, with one white stocking behind, and narrow stripe in the face, $15 \frac{1}{2}$ hands high, foaled in 1866 , bred by Mr. Davis, of Salem, Me., got by Flying Eaton, dam, an Eaton mare, a pacer. Davis sold him to Thomas Parker, of Kingfield, and he, when four years old, to Sam- 
uel Farmer, of Farmington. Farmer sold him in June, 1873, to Ed. Maynard, of Boston.

\section{HAMLET.}

Bay stallion, with heavy black mane and tail, one white hind foot, and small white stripe in face, $16 \frac{1}{2}$ hands high. and weighs 1150 pounds, foaled in 1866, bred by Mr. Ellsworth, Salem, Me., got by Flying Eaton, dam by Old Eaton.

Ellsworth sold him, when one year old, to Isaac Winter of Strong, and he.sold him, when five, to Silas Perham, of Farmington.

\section{DODGE.}

Bay geilding, with black mane and tail, and white hind feet, $15 \frac{1}{4}$ hands high, foaled in 1869, bred by George Dodge, Farmington, Me., got by Flying Eaton, dam, an Eaton mare. Dodge sold him, when two years old, to Samuel Farmer, now of Phillips.

\section{PHANTOM.}

Sorrel gelding with stripe in face, $15_{\frac{1}{2}}^{\frac{1}{2}}$ hands high, foaled in 1868, bred by Hiram Jennings, Farmington, Me., got by Flying Eaton, dam, a Drew mare. Jennings sold him, when three years old, to Silas Perham, of Farmington.

\section{PITT FESSENDEN.}

Sorrel gelding, with star in forehead, foaled in 1869, bred by Dr. Randall, Farmington, Me., got by Flying Eaton, dam by Brandywine. Dr. Randall sold him, in 1873, to Silas Perham, of Farmington. 


\section{MAZEPPA.}

Bay colt, with white hind feet, foaled in 1871, bred by Ira Sprague, Farmington, Me., got by Hamlet, dam, pedigree unknown. Sprague sold her, when three months old, to Dr. P. Dyer, of Farmington, for $\$ 10$.

\section{LADY FRANKLIN.}

Bay filly, with black points and white star in forehead, foaled in May, 1873, bred by A. G. Greene, Newport, Me., got by Hamlet, dam by Old Eaton.

\section{TOM HYER.}

Sorrel colt, $16 \frac{1}{2}$ hands high, foaled in 1869 , owned by $\mathrm{J}$. H. Carvill, Farmington, Me., got by Flying Eaton, dam, by Hiram Drew. 


\section{BRANDYWINE STOCK.}

\section{BRANDYWINE.}

The original Brandywine, known in Maine as "Cobb's Brandywine," was a dark bay stallion with black points, about $15 \frac{1}{2}$ hands high. He was brought to Maine from Canada about the year 1853 by Aaron Cobb, of Hebron, Me., who owned him until he died, two or three years afterwards. He was a well-bred horse, said to be nearly thoroughbred, with fine trotting action, and was fast.

\section{YOUNG BRANDYWINE.}

Mahogany bay stallion, with black mane and tail, 14 hands high, and weighed about 800 pounds. Bought in the City of Montreal, C. E.., in February, 1856, and brought to Maine by Henry A. Young, then of Hartford. Accompanying him was a certificate stating that he was then four years old, got by Brandywine, dam, by St. Lawrence. Mr. Young soon disposed of a one-half interest in him to Mr. Benjamin Young, of Hartford, and the other half to B. W. Briggs, of Sumner. He remained their property until 1861, when he was purchased by William Childs, of Mechanic Falls. After having several different owners he became the property of Mr. D. M. Foster, of Canton Point, in 1864. Here he remained 
during six of his best years. Mr. Foster sold him in 1870 to R. G. Dunn, of Wilton; he let Harvey B. Russell, of Canton, have him, and he took him to Abington, Mass., in 1871, where he is now owned.

Doubts have been expressed by many about his pedigree being as above stated, but it is not our purpose to go behind the record, leaving that to those curious in such matters.

\section{BENSON HORSE.}

Mahogany bay stallion, with dapples, $15 \frac{3}{4}$ hands high, and weighs about 1000 pounds, foaled in 1866, bred by Frederic Ellis, then of Hartford, Me., got by Young Brandywine, dam, a pacing mare, said to be of Morgan descent. Ellis sold him when one year old to America Benson, of Hartford, and he took him to North Abington, Mass., where he has since stood for service. He both paces and trots, and is said to be fast.

\section{GOLD BIRD.}

Golden chestnut stallion, under 15 hands high, foaled May 21, 1868, bred by Childs \& Foster, Canton Point, Me., got by Young Brandywine, dam, an English mare. Sold when four years old to R. G. Dunin, of Wilton, Me.

\section{ORPHAN BOY.}

Chestnut stallion, about $15 \frac{1}{2}$ hands high, foaled in 1856 , bred by Sumner Hayford, Hartford, Me., got by Cobb's Brandywine, dam, a Morgan mare, that took the first premium as breeding mare, at the Maine State Fair, in 1860. Hayford sold him when four years old to Otis 
Holt, of Turner. Holt sold him and he was taken to Chesterville, where he became the sire of Lady Burleigh.

\section{FOWLER'S BRANDY.}

Dark bay stallion, with black points, $15 \frac{1}{4}$ hands high, foaled in 1855, bred by Lon Tubbs, of Hebron, Me., got by Cobb's Brandywine, dam, said to be of Morgan descent. Tubbs sold him when five years old to Samuel $H$. Keen, of Hebron. In 1863, Keen sold him to Asia Jonès, of Turner, and he shortly afterwards to Gilbert Fowler, of Portland, and he became kncwn as "Fowler's Brandy." Fowler owned him until he died, a few years afterwards.

\section{GODING'S BRANDY.}

Brown bay stallion, with black points, 15 hands high, foaled in 1863, bred by Nahum Mitchell, of Turner, Me., got by Fowler's Brandy, dam, by Whalebone. Mitchell sold him when a sucking colt, to S. H. Keen, of Hebron, he sold him to Mr. Jenkins, and he to E. Goding, of Jay Bridge, when three years old. When four years old, Goding sold a one-half interest to Ephraim Childs, of Canton, and they shortly afterwards sold him to Daniel Hanscom, of Hallowell. Hanscom had him gelded, and in March, 1869, he sold him to New York parties. He was afterwards called "Jim Libby," under which name he won the first and second heats in a race at Boston, in June, 1869, time 2.40-2.37.

\section{TOM THUMB.}

Chestnut stallion, with star in forehead, and one white hind foot, $14 \frac{3}{4}$ hands high, foaled in 1859 , bred by Sullivan 
Barrett, of Sumner, Me., got by Young Brandywine, dam, the Barretl mare (so called), of Morgan descent. Amos Childs, of Canton, bought him in 1864, and gelded him, and sold him in 1866 to Lloyd Carver, of Portland.

\section{I.AMBERT.}

Mahogany bay stallion, 15 hands high, foaled in 1865, bred by Cyrus Hayford, of Hartford, Me., got by Young Brandywine, dam of Messenger descent. Hayford sold him, when two years old, to Harrey B. Russell, then of Hartford. Russell let R. G. Dunn, of Witton, have him, when six years old. Dunn took him to Boston, Mass., and sold him to Dr. Flagg.

\section{YOUNG BRANDYWINE (PRINCE'S).}

Bay stallion with black points, and small white stripe in face, weight near 1000 pounds, foaled in May, 1865, got by the William Keen horse, by Cobb's Brandywine, dam, pedigree unknown. Bred and owned by S. P. C. Prince, Webster, Me.

\section{BLACK WARRIOR.}

Black stallion, $15 \frac{1}{2}$ hands high, and weighs 1000 pounds, foaled in 1868, bred by Samuel S. Marston, of Hartford, Me., got by Young America, by Young Brandywine, dam, by Young Morgan, he by Whalebone, out of a bay Messenger mare, by the Bridgham hor'se. Young America's dam, by American Traveler, he by Lightfoot, he by the Josiah Dudley horse, and he by Old Traveler. Owned by Lucius L. Killbreth, Hartford, Me. 


\section{GLADIATOR.}

Dark bay gelding, 15 hands high, foaled in 1859 , bred by John Starbird, of Sumner, Me., got by Young Brandywine, dam, pedigree unknown. Starbird sold him when four months old to Joshua Young, of Hartford. Young sold him when five years old to Randolph Thomes, of Portland. Thomes sold him to F. S. Palmer and others for $\$ 2600$.

At Portland, Oct. 10, 1866, in a race against Emperor and others, he won the first heat in $2.39 \frac{1}{2}$, and was second in the race. He was afterwards sold and taken to New York.

\section{BUFFALO BILL.}

Alias "Dagon," alias "Bull-of-the-Woods." Dark brown gelding, $15 \frac{1}{2}$ hands high, foaled in 1863, bred by S. H. Keen, Hebron, Me., got by Fowler's Brandy, dam, of Morgan descent.

Keen sold him when three years old to E. Y. Turner, of Lewiston. Turner sold him to Dr. Strout, of Auburn, and he, in 1873, to L. J. Brackett, of Windham. He is perhaps best known as Dagon, under which name he trotted many races in the "forties." August 27, 1873, at the Lewiston Driving Park, he gुon a race as "Buffalo Bill," and a record of 2.35 .

\section{BROWN NATHAN.}

Brown gelding with black points, $15 \frac{i}{2}$ hands high, foaled in 1863, bred by a Mr. Scribner, of Otisfield, Me., got by the William Keene horse, by Cobb's Brandywine, dam, pedigree not traced. The Russell Bros., of Buckfield, 
bought him when five years old. While owned by them he won a race at Portland, Me., Sept. 10, 1869, the fastest heat being $2.41 \frac{3}{4}$.

\section{LADY ANNA.}

Bay mare, with black points, $14 \frac{3}{4}$ hands high, foaled in 1863, bred by Ephraim Childs, of Canton, Me., got by Tom Thumb, dam, by Young Brandywine. In 1869, she obtained a record of 2.44, in a race at Farmington, and Childs sold her to Messrs. Farmer \& Tarbox, for $\$ 1000$.

\section{LADY DAMON.}

Brown mare, with small star, and white on one hind foot, 15 hands high, and weighs about 1000 pounds, foaled in 1863, bred by John Damon, Buckfield, Me., got by Fowler's Brandy, dam, a gray mare, by the Hunton Horse. While Damon owned her she trotted several ice races, and was thought to be quite fast. In the spring of 1871, he sold her to John Langley, of Worcester, Mass.

\section{LADY BURLEIGH.}

Gray mare, $14 \frac{3}{4}$ hands high, foaled in 1865 , in Chester. ville, Me., got by Orphan Boy, dam, of Messenger descent. Purchased when five years old by H. C. Burleigh, of Fairfield, who sold her in 1873, to R. H. Dunlap, of Boston, Mass., for $\$ 2,700$. She trotted several races, while owned in Maine.

\section{PATTY W.}

Bay mare, foaled in 1856 , bred by Asia Jones, then of Turner, Me., got by Cobb's Brandywine, dam, by Whale- 
bone. Subsequently purchased by Dr. J. L. Wheaton, Pawtucket, R. I. .In 1871, foaled Leda, bay mare, by Aberdeen, by Rysdyk's Hambletonian. In 1873, foaled Meta, bay mare, by Aberdeen, by Rysdyk's Hambletonian.

\section{WHITENOSE.}

Brown gelding, with black points and white in face, $15 \frac{1}{4}$ hands high, foaled in 186-, bred by Samuel Wardwell, Oxford, Me., got by the Wm. Keene horse, by Cobb's Brandywine.

Wardwell sold him to John Hill, of Stoneham, Mass., and he to Chas. C. Emery, of Skowhegan, Me. While in Maine he won a race at Farmington, Me., beating Carthage Boy in three straight heats, the fastest being $240 \frac{1}{2}$. Mr. Emery sold him to J. D. Walton, of New York.

\section{LEEDS.}

Chestnut gelding, with star in forehead, $15 \frac{1}{2}$ hands high, foaled in 1866, bred by Sylvester Brown, of $\mathbf{E}$. Livermore, Me., got by Orphan Boy, dam by the Allen Horse. Brown sold him, when two years old, to Chesman D. Gould, of North Leeds, Me., and Gould sold him in 1873, to Geo. M. Delaney, of Lewiston.

At the Knox county fair, at Rockland Me., Oct. 11, 1873 , Leeds won a race, beating a field of five, the fastest heat being $2.42 \frac{1}{4}$.

\section{MAUD MULIER.}

Chestnut mare, about $15 \frac{1}{2}$ hands high, foaled in 1867 , bred by C. M. Holland, Canton Point, Me., got by Young 
Brandywine, dam, not traced. Mr. Holland sold her, when four years old, to Ephraim Childs, of Canton, and W. H. H. Wood, of Livermore Falls.

\section{PLOW BOY.}

Bay gelding, with black mane and tail, 15 hands high, foaled in 1868, bred by Ephraim Childs, of Canton, got by Young Brandywine, dam, by the Knights Horse. 


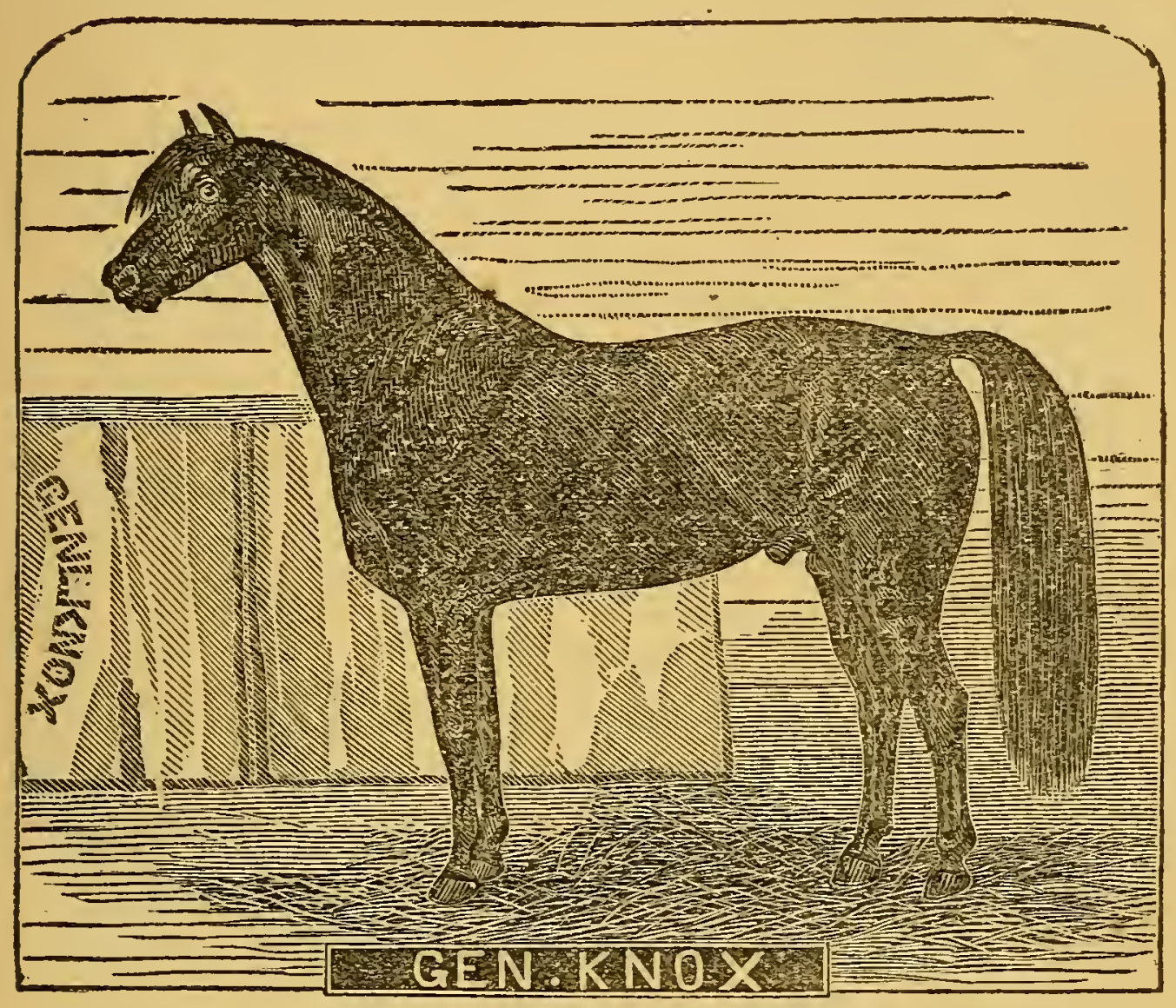

\section{KNOX STOCK.}

\section{GEN. KNOX.}

Black stallion, $15 \frac{1}{2}$ hands high, and weighs 1050 pounds, with star in forehead, stripe of white on nose and upper lip, with brownish nose, flanks and stifies; foaled in 1855. He was purchased in 1855, of Denny \& Bush, of Shoreham, Vt., and brought to Maine, by Col. Thomas S. Lang, of Vassalboro, and was then called Slasher. He was always said to be by Sherman Black Hawk, while owned 
in Maine, but the researches of Mr. J. H. Wallace clearly establish the fact that the sire of Gen. Knox was Vermont Hero, and not Sherman Black Hawk (his grandsire) as was long published. His pedigree we give below in tabulated form :

\section{PEDIGREE OF GEN. KNOX.}

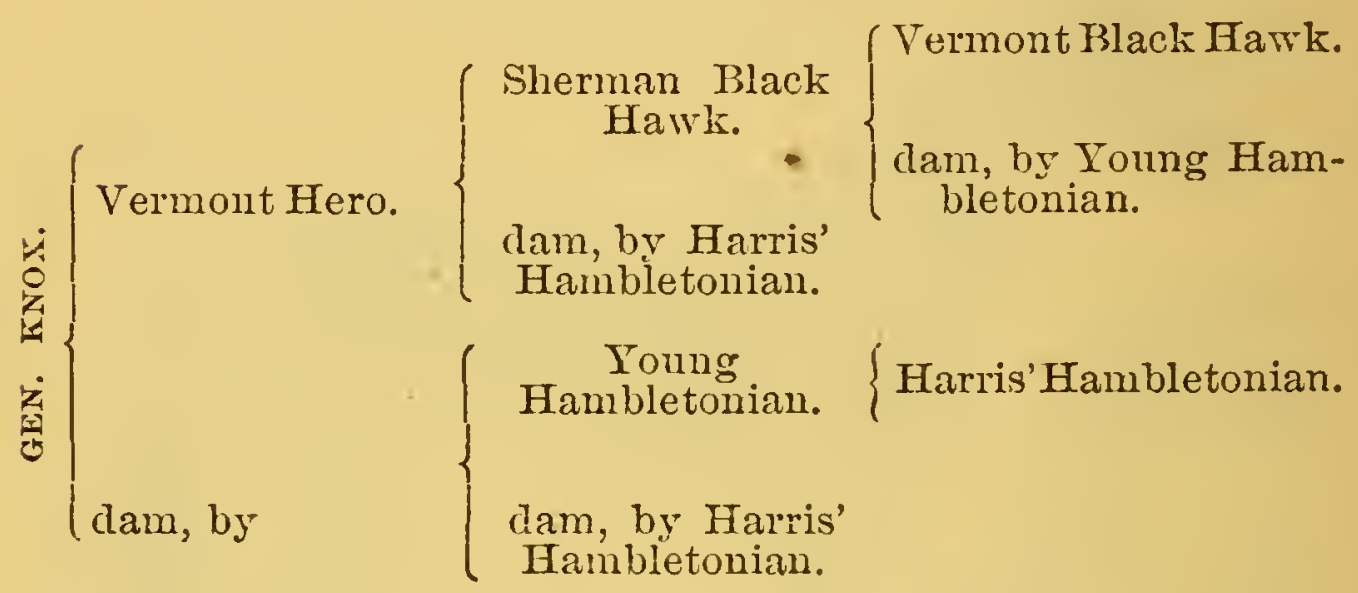

Gen. Knox's performances on the turf have been few in number and always made in poor condition, as he stood for service every season while orned in Maine. Among them, however, are the following: At Waterville, Me., Oct. 22, 1863, he beat Hiram Drew, and won a record of 2.32. In 1864, in Sept, at the first exhibition of the New England Agricultural Society, held in Springfield, Mass., he beat Draco, Duke of Wellington, and one other, in three straight heats in $2.31 \frac{1}{2}, 2.37,2.34 \frac{1}{2}$, making the first balf mile in the first heat in 1.14, and the first half mile in the third heat in 1.15, and winning the distinction as "Champion of New England," which he has ever since hell.

He was in very poor condition to trot at the time this race was made, having received no training, but on the contrary had covered mares to within twenty days of the time of the race. In 1871 , he was entered in the 2.30 
class, at Buffalo, and during his preliminary preparation turned the track in 2.26 , but a subsequent lameness prevented his starting for the premium.

After a very successful career in the stud, in Maine, where he has left a numerous progeny, he was sold in 1872, to Mr. H. N. Smith, of New York, for $\$ 10,000$.

The Spirit of the Times, of Dec. 20, 1873, in speaking of Gen. Knox, says: "Gen. Knox is a grand horse, eighteen years old, with legs and feet as sound and clean as a wild deer's, and the sire of Camor's, Lady Maud, Gilbreth Knox, Plato, and many others. He is a natural trotter, and even now can show an astounding burst of speed when given his head in his exercise. There are few sires whose get are so "chock full of trot," to use a clown-east expression. "A Knox that cannot trot is a rarity," says an expert horseman who has been handling them for years. "Gen. Knox is now located at the Fashion Stud Farm, near Trenton, N. J., and is the property of its proprietor, Mr. H. N. Smith, owner of Goldsmith Maid, Lady Thorn, Socrates, Tattler, and part owner of Jay Gould."

"In this brilliant galaxy, Knox attracts a due proportion of interest. He received many mares last season from remote points, and the astute banker who owns him considers him a remunerative and truly valuable investment."

It may not be uninteresting to state that the celebrated mare Lady Thorn was bred to Gen. Knox, in 1873, in preference to Hambletonian or his descendants, and her colt foaled Feb. 22, 1874, called Gen. Washington, in honor of the day on which he was foaled, is described by the Spirit of the Times as "a large and finely formed bay colt with black points, light about the head and neck, 
nostrils and ear's very thin, neck long and slim, with strong and well-formed legs," and the probability is should no misfortune befall him, he will prove worthy of his illustrious breeding, and perpetuate the fame of his sire and dam.

\section{CAMORS.}

Black gelding with no white marks, $15 \frac{1}{2}$ hands high, foaled in 1864, bred by Levi Atwood, Portland, Me., got by Gen. Knox.

His dam was bred by Gen. Peleg Wadsworth, of Hiram, Me., and was got by a very common horse, raised and always kept in Hiram, and out of a mare whose pedigree Gen. Wadsworth does not know. When two years old Mr. Atwood sold him at auction, and he became the property of R. O. Conant, of Portland.

He was afterwards sold to Lon Morris, of Boston, who named him, for over $\$ 2000$. He sold him to John F. Merrow, also of Boston, for $\$ 11,500$. August 15, 1872, at Utica, N. Y., Camors won the race for horses that never beat 2.50 in straight lieats, in $2.30,2.29,2.31 \frac{1}{2}$, for a purse of \$3000. August 20, at the Hampden Park, Springfield, Mass, he won the 2.30 race, beating ten horses in straight heats, in $2.34 \frac{3}{4}, 2.32 \frac{3}{4}, 2.30 \frac{1}{4}$. Sept. 10, 1872, at Mystic Park, Boston, he beat Gray Eddy, Dauntless, and Lydia Thompson, in straight heats, time $2.27,2.25 \frac{1}{2}, 2.26 \frac{1}{2}$.

His crowning triumph for the season was achieved at the Prospect Park, Brooklyn, Sept. 19, where he beat Judge Fullerton, IV. H. Allen, Lulu, and Triumph, winning the first and second heats in $2.23,2.21 \frac{3}{4}$, and the fourth in $2.23 \frac{1}{4}$.

He wintered at the Mystic Park, Boston, and August 16,1873 , he trotted a race at Bufialo, N. Y., against Judge 
Fullerton, Sensation, and other fast ones. Camors won the first and fastest heat in $2.20 \frac{1}{2}$, and the second in $2.21 \frac{3}{4}$, but lost the race. The Spirit of the Times, in speaking of the race at Buffalo,'says, "Camors had the speed of them all, and doubtless could have beaten any one singly. The least that can be said is that he fairly surprised his most sanguine friends, and scored a record that will be pointed to with pride by the admirers of the Knox blood."

"The first heat done in $2.20 \frac{1}{2}$ was a remarkable performance, under the circumstances, and if the track had been in good condition, there is little doubt but the time would have been down in the 'teens."

Sept. 27, 1873, at Prospect Park, in a race for horses that never beat 2.20 , for a purse of $\$ 3000$, Camors, Sensation, Huntress, W. H. Allen and Gazelle were entered. Sensation won the first and second heats in $2.22 \frac{3}{4}, 2.24$, and Camors the next three and race in $2.23 \frac{1}{4}, 2.22 \frac{1}{2}$, $2.24 \frac{3}{4}$, making five heats, all under 2.25 .

\section{LADY MAUD.}

Dark brown mare, over 15 hands, foaled June 15, 1867, bred by Col. T. S. Lang, North Vassalboro, Maine, got by Gen. Knox, dam, Mocking Bird, a fast mare brought from New York, by Abner Barrows, got by a running horse called Sabek. After Mr. Lang went to Europe, Lady Maud was sold, and finally taken to New York.

August 8, 1872, at the Buffalo Park, she trotted a race for horses five years old and under, for a purse of $\$ 1500$, winning in straight heats in $2.29 \frac{1}{2}, 2.29 \frac{3}{4}, 2.27 \frac{1}{4}$, beating Zilcadie Golddust, Mary H., Rowe's Tommy and Vanity Fair.

Oct. 10, 1872, she won a matched race for $\$ 5000$, at the Prospect Park, beating Lucille Golddust. 
The first heat Lady Maud won in 2.301 lost in $2.29 \frac{1}{2}$, and the fourth and fifth she won in the remarkably fast time of $2.22 \frac{3}{4}, 2.22 \frac{1}{4}$, which is said to be the fastest recorded for the age. In 1873 she was bred to Jay Gould, who has the fastest public record of any stallion living.

\section{GILBRETH KNOX.}

Black stallion, $15 \frac{3}{4}$ hands high, and weighs about 1075 pounds, foaled in 1862, bred by Samuel Guild, of Augusta, got by Gen. Knox, dam, the Cahill mare so called, brought from the West, and pedigree unknown. Guild sold him when about a year old to J. H. Gilbreth, of Kendall's Mills, Me. After Mr. Gilbreth's death he was sold to Mr. A. Wentworth, of Boston, for $\$ 1700$.

Among his performances on the turf while owned in Maine are the following: Sept. 7, 1869, at Portland, Me., he beat Gen. McClellan, winning the last three out of four heats in $2.37 \frac{1}{2}, 2.40,2.37$. Two days afterward he beat him again in 2.34, 2.36. Sept. 25, 1869, in a race at Boston, Mass., he won the first heat in 2.31. The second was a dead heat between Gilbreth Knox and McClellan, and the time was again 2.31. At Narragansett Park, Oct. 7, 1869 , in a race for horses that never beat 2.31, there were ten entries. Twang won the first heat in $2.28 \frac{1}{2}$, and Gil-

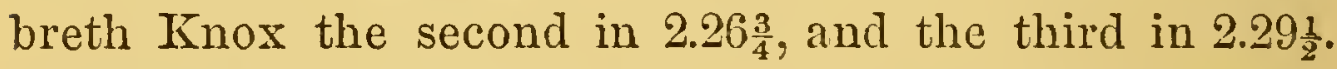
As they were coming down for the word, in the third heat, Gilbreth Knox's driver drove too near the pole, and was thrown out of his sulky. He hung to the reins after he was overboard, but Knox was a little frightened and was finally let go, trotting half way around the course alone, when he held up and was captured. Another vehicle was furnished and they got the word. 
The fourth heat was won by Twang, the fifth by Topsey, and the sixth lay between Twang, Topsey and Knox, all the rest who had not won a heat being out. Gilbreth Knox was thought by many to be the fastest of the three, but he was distanced, and the heat and race won by Twang. Sept. 29, 1871, at Portland, Me., he beat Shepherd Knapp, $\mathrm{jr}$., and others in staight heats in $2.32 \frac{1}{2}, 2.3 \frac{1}{4}, 2.37 \frac{1}{4}$.

\section{LOTHAIR.}

Black stallion $15 \frac{3}{4}$ hands high, and weighs about 1050 pounds, foaled in 1867, bred by the late J.H. Gilbreth, of Fairfield, Mee., got by Gilbreth Knox, dam, the Bunker mare, by Old Eaton.

He was formerly called Knox-them-all, and Mr. Gilbreth sold him to Messrs. Wright \& Norcross, of Fearnaught Farm, for $\$ 5000$. As a three-year old he gained considerable notoriety for his race against "Startle" by Hambletonian, which took place Sept. 1,1870 , at the Prospect Park, L. I., for a purse of $\$ 5000$. His first season on the turf was in 1873, during which he was very successful. June 10, at the Forest City Park, Portland, Me., he won the race for horses that never beat three minutes, beating Baby Boy, Flora and Lady Walton, with a record of 2.48, the fastest heat-2.45-being won by Baby Boy. Two days afterward, at the same place, he won the 2.50 race in straight heats, time, 2.45, 2.44, 2.45 .

June 27, at Mystic Park, Boston, he won a race in

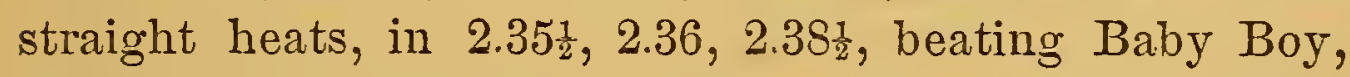
Medoc, Rex Patchen, Lady Hamilton, Ludlow Boy, Folly and Jim Fisk.

July 3, at the Beacon Park, he beat Flora Belle and

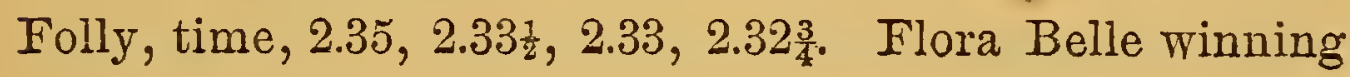
$6^{*}$ 
the first heat. August 2S, at the same place he beat Col. Moulton, Neliy, Jubilee Lambert, Flora Belle and Ben Smith, winning the first heat in 2.33 , the third in 2.33 and the fourth and race in 2.35 .

At the Maine State Fair, of 1873 , at Bangor, in a race for the "Champion's Belt," open to all stallions owned in Maine, there were the following entries: Gen. Lightfoot, Slasher, Red Jacket and Lothair. The race was won by Lothair in straight heats, time $2.35 \frac{1}{2}, 2.38 \frac{1}{2}, 2.34$.

\section{GEN. LIGHTFOOT.}

Dark bay stallion, with black points, under 15 hands high, and weighs about 900 pounds, foaled in July, 1865, bred by Watson Blaisdell, of Burnham, Me., got by Gen. Knox, dam, a thoroughbred English mare. Mr. W. D. Atkinson, of Pittsfield, subsequently purchased a onehalf interest in him, and in 1873 he was sold to Mr. V. C. Hall, of Windham. Aug. 13, 1873, at Foxcroft, Me., Gen. Lightfoot won a race in three straight heats, in 2.39, $2.41 \frac{3}{4}, 2.36 \frac{1}{2}$.

August 28, 1873, at the Lewiston Driving Park, a race came off for a purse of $\$ 1000$, open to all stallions owned in Maine, and for which the following entries had been made, viz: May's Bismarck, King William, Phil. Sheridan, Slasher, and Gen. Lightfoot. When the day arrived King William was unable, from a temporary lameness, to start, and a serious accident, the result of a collision while exercising, in which a valuable mare, Virgin Mary, was killed, and Bismarck seriously injured, prevented him from starting, so that Phil. Sheridan, Gen. Lightfoot and Slasher-all by Gen. Knox-were left to contend for the prize. Sheridan won the first heat in $2.36 \frac{1}{2}$, and the 
second in 2.36. On coming up for the third heat, A. W. Worcester, of Boston, was on Gen. Lightfoot's sulky, in place of his owner, Mr. Hall, who had driven him in the two previous heats. After repeated scoring they finally got the word, and Lightfoot shot at once to the front, and maintained his lead throughout, winning the heat in 2.34, Sheridan just saving his distance, and Slasher distanced. The fourth and fifth heats and race were also won by Gen. Lightfoot. Sept. 10, 1873, at the opening of the Oakland Park, Gardiner, Me., in a race for horses that never beat 2.32; Gen. Iightfoot won the third, fifth and sixth heats and race in 2.34, 2.39, 2.40.

In Oct., at Rockland, he beat Red Jacket, King William and Honest Quaker in straight heats.

\section{PHIL. SHERIDAN.}

Black stallion, with star in forehead, $15 \frac{1}{2}$.hands high, and weighs 1075 pounds, foaled July 27, 1864, bred by Greenleaf Lowe, of Winslow, Me., got by Gen. Knox, dam, pedigree not traced.

P. M. Thurlow, of Lewiston, purchased him when about two months old. During the season of 1872 he trotted eleven races, winning first money in seven, second money in three and losing one. He gained considerable notoriety for his many contests with King William. His fastest performance for the year was in the stallion race at the State Fair, at Bangor, in September, which he won ; fastest heat 2.36, and a half in 1.15. In 1873, Aug. 28, at the Lewiston.Driving Park, in a race for stallions owned in Maine, for a purse of $\$ 1000$, he won the first heat in 2.36 $\frac{1}{2}$, and the second in 2.36.

At the Maine State Fair, at Bangor, in Sept., be won 
the race in the 2.35 class, beating Red Jacket and Lady Knox.

\section{PALMER KNOX.}

Dark brown stallion, with black points and star in forehead, $15 \frac{1}{2}$ hands high, and weighs 1100 pounds, foaled in 1865, bred by M. G. Palmer, of Portland, Me., got by Gen. Knox, dam by Robinson horse, he by Bucephalus, by Mambrino, by Imp. Messenger.

The accompanying engraving of Palmer Knox was made expressly for this work, from a painting from life, by Mr. G. H. Bailey, the well-known artist, whose name is a sufficient guarantee of its truthfulness. Palmer Knox, with his fine size, beautiful proportions and astonishing muscular development, realizes our ideal of a fast and lasting trotter. At the Maine State Fair, in 1873, at Bangor, he won the three-minute race in a field of ten horses, in straight heats, best time 2.40. The next day he won the race for horses that never beat 2.48, in a field of seven. The first heat was won by Pequawket, in $2.38 \frac{1}{2}$. The second by Palmer Knox, in 2.38, who also won the fifth and sixth heat and race in $2.40 \frac{1}{4}, 2.40$.

The next week at Portland he won the first premium on two successive days, making but one break in each day.

\section{MAINE SLASHER.}

Formerly called "Fairfield Boy," bay stallion with black points, $15 \frac{3}{4}$ hands high, foaled in 1865 , bred by the late Henry Lawrence, of Fairfield, got by Gen. Knox, dam, Juno, by Norman, or the Crawford horse, $2 d$ dam by Witherell. He was sold, when five years old, to Messrs. Archer \& Jones, at auction, for $\$ 515$. They sold 


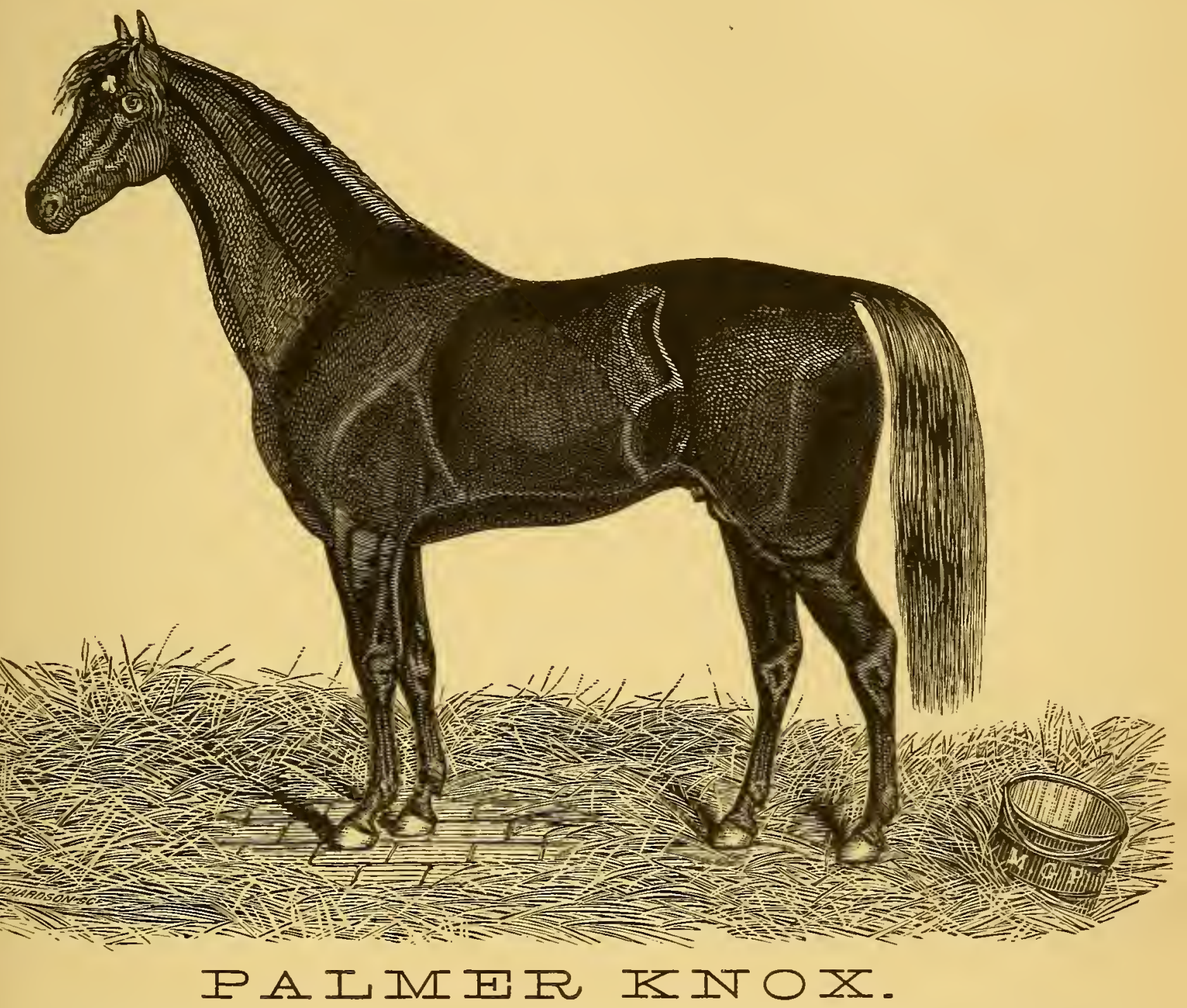

Foaled in 1865; Sire Gen'1 Knox; Dam by Robinson Horse, he by Bucephalus, he by Mambrino, he by Imported Messenger.

Palmer Knox weighs 1100 pounds, and is second to none in the country, being equally adapted for work, riding or speed. His size, style, color, disposition, bottom and speed, together with power to transmit these good qualities to his oft'spring, gives him the preference over all other horses now standing for breeding purposes.

E. H. MCKENNEY, BIDDEFORD. M. G. PALMER, Portlain. 

him to H. B. \& E. H. Jones, also of Fairfield. He was subsequently owned by Withee \& Gray, of Waterville, and finally by Gen. Wm. S. Tilton, of Togus, Me.

In August, 1873, at South China, Me., he won a race, beating Red Jacket in straight heats, each being just 2.40.

Shortly after he beat Gentle Annie and Red Jacket at the same place. Gentle Annie won the two first heats each in 2.38, and Slasher winning the next three and race, the fastest being in 2.40 .

\section{MESSENGER . KNOX.}

Gray stallion, $16 \frac{3}{4}$ hands high, and weighs 1100 pounds, foaled June 12, 1866, bred and owned by G. \& L. P. Warren, Westbrook, Me., got by Gen. Knox, dam by "Prince," owned by Jas. Jack, of Portland, he by the Lowell horse, and he by Quimby Messenger, grand dam by a grandson of American Eclipse. Young Eclipse, by American Eclipse, was purchased on Long Island, and brought to Maine by Robert Green, Esq., of Saco, Me., where he was kept for several years as'a stock horse, and the grand dam of Messenger Knox was by one of his colts.

At the opening of the Oakland Park, Gardiner, in Sept., 1873, Messenger Knox won three races. The threeminute race in $2.46,2.46,2.46 \frac{1}{2}$. In the 2.50 race he obtained a record of 2.45 .

\section{HONEST JOHN.}

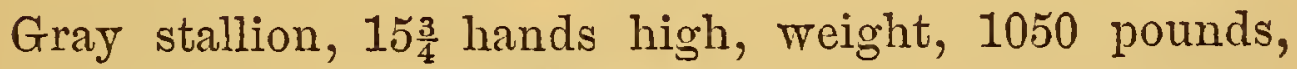
foaled in 1866, bred by Mr. Woodsome, Clinton, Me., got by Gilbreth Knox, and is said to be his oldest colt, dam, white mare, Phantom, by Grover's Messenger. The late 
J. H. Gilbreth, of Kendall's Mills, bought him before he was one year old, and sold him, when three, to Messrs. Tozier \& Jones, of Fairfield, for $\$ 800$. They sold him, the same season, to Rodney Jones, for $\$ 1300$. Mr. Jones sold him, when five years old, to Smith \& Jordan, of Oldtown, for $\$ 2000$. As a four-year old he took the first premium in his class at the North Kennebec Agricultural Society Fair, also, for fastest trotting stallion, at same place. The next season, at Waterville, he won the stallion purse for all ages, beating Black Ranger and Gen. Knox, jr. He also won the three-minute purse at Skowhegan and Dover the same season. He was a horse of large bone, and good deal of muscle, and had a big, open, slashing gait. He died in Oldtown, in 1873, from the effects of a kick.

\section{T. S. LANG.}

Gray stallion, $15 \frac{1}{2}$ hands high, foaled in 1865 , bred by Mr. Woodsome, of Clinton, Me., got by Gen. Knox, dam, Phantom (the dam of Honest John), by Grover's Messenger.

Mr. Woodsome sold him to the late J. H. Gilbreth, of Fairfield, and he sold him, when four years old, to Messrs. N. Tozier \& H. B. Jones, also of Fairfield. In 1870 he met with an accident in the town of Mercer, which caused his death. He broke out of the stable with a stick of wood to which his halter was attached, and it entered his body, which caused his death in a few days. He was a fine styled horse. He took the second premium in his class at the New England Fair, at Portland, in 1869.

\section{JULES JURGENSEN.}

Formerly "Logan," or the "Littlefield horse." 
Brown stallion, $15 \frac{1}{2}$ hands high, and weighs 1050 pounds, foaled July 27,1862 , bred by Geo. Knowell, North Vassalboro', MIe., got by Gen. Knox, dam, the Knowell mare (so called), by Young Abdallah. Knowell sold him when two years.old to J. M. Littlefield, of Abbott, Me. Littlefield owned him until 8 years old, when he was sold to Chas. Carman, of New York City, it is said for $\$ 1600$. He had, while owned in Maine, a public record of $2.41 \frac{1}{2}$, but had trotted in private in $2.28 \frac{1}{2}$.

\section{PLATO.}

Dapple gray stallion, $15 \frac{3}{4}$ hands high, and weighs about 1050 pounds, foaled June 10, 1863, bred by William H. Longley, Norridgewock, Me., got by Gen. Knox, dam by Allen .horse, alias Norridgewock Messenger. Longley sold him when four months old to Alpheus and Ora O. Crosby, of Albion, Me. He obtained a record of 2.45 at the North Kennebec Fair, as a five-year old. At the New England Fair, in Portland, in 1869, he won the race in the 2.45 class, easily, in 2.45 .

In 1871, at the Narragansett Park, he obtained a record of $2.31 \frac{1}{4}$, and was afterwards sold to Mr. Buck, of Buffalo, N. Y., for $\$ 12,000$. It is claimed that he has a public record of 2.27 , but we have been unable to find it.

\section{SKOWHEGAN BOY.}

Black stallion with stripe in face, $16 \frac{1}{4}$ hands high, bred in Winslow, Me., got by Gen. Knox, dam, of Messenger descent.

Mr. Nodine, of Brooklyn, N. Y., bought him, when tro years old, and took him to New York. He was brought back, when five, and owned by Hill \& Emery, of Skowhegan, where he died in June, 1869. 


\section{GEN. SHERMAN.}

Black stallion, $15_{4}^{3}$ hands high, and weighs about 1000 pounds, foaled in 1862 , bred by the late Col. J. L. Seavey, of Waterville, got by Gen. Knox, dam by, Hiram Drew. Mr. Seavey sold him to Abram Woodard, Esq., proprietor of Penobscot Exchange, Bangor, Me. June 10, 1870, at Foxcroft, Me, he won a race, beating Bully Brooks (now Bangor) and Dashaway, getting a record of $2.37 \frac{1}{2}$.

\section{MONMOUTH KNOX.}

Formerly "Monmouth Boy." Mahogany bay staliion, $15 \frac{1}{2}$ hands high, and weighns 1025 pounds, foaled in June, 1866, bred by Oren True, Litchfield, Me., got by Gen. Knox, dam not traced. Purchased when one year old, by G. C. \& A. T. Crosman, Monmouth, Me.

\section{D'ISRAELI.}

- Chestnut stallion, with light mane and tail, 16 hands high, and weighs about 1050 pounds, foaled in 1S67, bred by Mr. Hobart, of Temple, Me., got by Howe's Bismarck, dam, of Morgan descent. Hobart sold him, in 1872, to Messrs. Wright \& Nol'cross, of Manchester.

\section{RIDLEY'S KNOX.}

Black stallion, $15 \frac{1}{4}$ hands high, and weighs about 950 pounds, foaled in 1855 , bred by the Ridley Bros., Wayne, Me., got by Gen. Knox, dam, a fast trotting mare, by Old Eaton.

\section{DRUMMOND KNOX.}

Black stallion, with white star in forehead, and spot on nose, 17 hands high, and weighs about 1250 pounds, 
foaled in May, 1867, bred by Clark Drummond, Winslow, Me., got by Gen. Knox, dam, by a Messenger horse, and out of a mare brought from Toronto, Canada West, and said to be of English blood. Drummond Knox has never been broken to harness, and consequently has no record for speed.

\section{GARDNER KNOX.}

Black stallion, 17 hands high, and weighs 1200 pounds, foaled May 22, 1868, owned by O. D. Gardner, Vassalboro, Me., got by Gen. Knox, dam, of Messenger descent.

\section{BLACK SULTAN.}

Black stallion, 16 hands $2 \frac{1}{2}$ inches high, and weighs 1250 pounds, foaled May 20, 1851, bred by Benjamin Bussey, Dixmont, Me., got by Gen. Knox, dam, a black mare of Morgan and Messenger descent. Black Sultan was purchased, when young, by C. Butman, Esq., Plymouth, Me. He has a record of $2.40 \frac{1}{2}$ in a race which he won in 1868.

At the New England Fair, in 1869, held in Portland, he trotted a half mile in 1.16. Has trotted the Bangor Track, without previous fitting, in $2.34 \frac{1}{4}$.

\section{KNTOX, JR.}

Black stallion, with tan muzzle and flanks, $15 \frac{1}{4}$ hands high, and weighs 1000 pounds, foaled in 1865, bred by Samuel Lyford, St. Albans, Me., got by Gen. Knox, dam, by the Merrow horse. He was purchased by $A$. W. Brackett, of Pittsfield, Me., while young, and at the New England Fair, of 1871, at Lowell, Mass., he was awarded 
the first premium for stallions five years old, and under eight.

\section{FAIRFIELD KNOX, FORMERLY LEO.}

Black stallion, $15 \frac{1}{4}$ hands high, and weighs 1000 pounds, foaled in 1864, bred by the late Henry Lawrence, of Fairfield, Me., got by Gen. Knox, dan, Juno, by Norman, 2d́d dam, by Old Eaton. Messrs. Toby, Burleigh \& Jones, of Fairfield, bought him at auction, for $\$ 1450$, and sold him to Charles A. Fuller, for $\$ 1700$, and he took him to Pennsylvania, when he was six years old. He was sold in 1873, for $\$ 2000$, and taken to Gallatin Valley, Montana, and owned by E. M. Dumphey, of Hamilton. He is a well and strong made horse, with good action, but had no public record while owned in Maine.

\section{OTHELLO.}

Dark brown stallion with star in forehead, and white spot on inside of left hind foot, $15 \frac{3}{4}$ hands high, and weighs 1050 pounds, foaled June 27, 1869, bred by Charles C. Perkins, Newcastle, Me., got by Col. Ellsworth, by Gen. Knox, dam, by the Call horse.

\section{GEN. KNOX, JR.}

Dark bay stallion, with black points, 15 hands $1 \frac{1}{2}$ inches high, and weighs 1000 pounds, foaled in 1863, bred by Woodbury Edwards', Brooks, Me., got by Gen. Knox, dam, by Morgan Messenger, 2d dam, a thoroughbred mare. He was subsequently purchased by Messrs. Kimball \& Jacobs, and stood for service, during the season of 1873, at Auburn, Me. 


\section{GEN. BERRY.}

Black stallion, with star in forehead, $16 \frac{1}{2}$ hands high, and weighs 1150 pounds, foaled July 28th, 1867, bred by Mr. Nelson, of North Vassalboro, Me., got by Gen. Knox, dam, of Messenger descent.

Purchased, when about three years of age, by Robt. Crockett, Rockland, Me. He took the first premium at the Knox County Fair, when three years old, and his owner refused $\$ 2000$ for him. He has trotted a half mile in private, without training, in 1.20 .

\section{TOM. LANG.}

Dark bay stallion, with black points, and no white marks, $15 \frac{1}{\frac{1}{2}}$ hands high, and weighs 1050 pounds, foaled June 30, 1863, bred by George B. Wellington, Presque Isle, Me., got by Gen. Knox, dam, by Chandler's Moscow, he by Old Moscow. He has a record of 2.45 in the first race in which he ever started, and this is his only public record.

\section{NORRIDGEWOCK.}

Black stallion, with brown muzzle and flanks, 15 hands high, and weighs 1000 pounds, foaled June 15, 1866, bred by B. E. Townsend, of Norridgewock, Me., got by Gen. Knox, dam, by Old Eaton.

When three years of age, Mr. Townsend sold a onehalf interest to H. C. Copeland, of Calais, and Norridgewock was taken to that city, where he has since been kept for service.

\section{COL. DUNNING.}

Black stallion, with star, foaled May 18, 1871, owned by 
J. H. Crowell, Corinna, Me., got by Bonnydoon, by Black Sultan, dam, by Witherell.

\section{FAIRFIELD KNOX (FULLER's).}

Black stallion, with star, and spot on nose, and near hind foot white, $15 \frac{1}{2}$ hands high, foaled 1871, bred by N. Tozier, Fairfield Centre, Me., got by Gen. Knox, dam, by Young Morrill. Owned by C. A. Fuller, Fairfield Centre, Me.

\section{GRAY ROSE.}

Gray mare, 16 hands high, foaled in 1869 , owned by C. A. Fuller, Fairfield Centre, Me., got by T. S. Lang, by Gen. Knox, dam, said to be a half-bred mare.

\section{ST. ELMO.}

Mahogany bay stallion, with black points, $15 \frac{1}{2}$ hands high, and weighs 1032 pounds, foaled May 29, 1864, bred by Samuel Chaffee, Vassalboro, Me., got by Gen. Knox, dam of Messenger descent.

St. Elmo has no public record, but has trotted a mile in 2.38 in private, and a half in $17 \frac{1}{2}$.

\section{PRESCOTT'S KNOX.}

Black stallion, with small white star, $15 \frac{3}{4}$ hands high, and weighs 1050 pounds, foaled May 6, 1870, bred by George Blackwell, Winslow, Me., got by Gen. Knox, dam, by Hunter, he by Witherell.

He was purchased by Josiah Prescott, Vassalboro, Me., and called Prescott's Knox. 


\section{COL. TOM KNOX.}

Dark bay stallion, with stripe face, and white hind feet, $15_{2}^{\frac{1}{2}}$ hands high, and weighs 1016 pounds, foaled July 6, 1867, bred by Col. T. S. Lang, North Vassalboro, Me., got by Gen. Knox, dam, by Witherell.

He was purchased Sept. 22, 1858, of Col. Lang, by R. H. Condon, Esq., of Brooksville, Me.

\section{LON. MORRIS.}

Black stallion, with brown points, and star in forehead, 16 hands high, and weighs 1100 pounds, foaled June 11, 1867, bred by William Abbott, near Getchell's Corner, Vassalboro', Me., got by Gen. Knox, dam, the Abbott mare (so called), by Homan's Messenger.

Abbott sold him to Walter B. Nutter, of Cape Elizabeth Depot, where he is kept for service. He took the first premium at the New England Fair, in 1869, over sixty-three entries.

\section{KNOX BOY.}

Brown stallion, 15 hands $1 \frac{1}{2}$ inches high, foaled in 1868 , bred by Isaac Carr, Farmingdale, got by Gen. Knox, dam, by Lewiston Boy.

At the State Fair of 1872, at Bangor, Me., he won the race for four-year olds, and a record of 2.45 .

\section{JUNIPER.}

Dark bay stallion, with black points, star in forehead, and small white spot on upper lip, foaled July 15, 1870 , bred by E. J. \& G. W. Lawrence, Fairfield, Me., got by Gen. Knox, dam (the dam of. Butterball), by 'Homan's Messenger. 


\section{KNOX TELEGRAPH.}

Dark bay stallion, with black points, $15 \frac{1}{2}$ hands high, and weighs 900 pounds, foaled April 27, 1870, owned by F. H. Brann, North Vassalboro, Me., got by Gen. Knox, dam, a bay mare, by Lang's Telegraph.

\section{PLAYAWAY:}

Bay stallion, with black points, $15 \frac{1}{4}$ hands high, foaled in 1869, bred by the late J. H. Gilbreth, of Fairfield, Me., got by Gen. Knox, dam, thoroughbred, by Lexington.

UNCLE SAM, FORMERLY QUAKER GENERAL.

Gray stallion, with blaze face, spot on nose, and one white eye, 16 hands high, foaled in 1868, bred by Friend Samuel Taylor, Fairfield, Me., got by Gen. Knox, dam, Nelly, white mare, by Allen's Messenger. Mr. Warren George bought him, when one year old, and sold him, in the Spring of 1873, to II. B. \& E. H. Jones, of Fairfield, for $\$ 1000$.

\section{COUPON.}

Black stallion, with tan colored muzzle and flanks, $15 \frac{1}{4}$ hands high, without shoes, and weighs over 1050 pounds, foaled June 7, 1867, bred by George Knowell, Esq., North Vassalboro', Me, got by Gen. Knox, dam (the dam of Jules Jergensen, formerly called Logan), by Young Abdallah. Coupon was subsequently purchased by James Edgecomb, Brownfield, Oxford county, Me.

\section{ROYAL TANNER.}

Black stallion, with star and stripe in face, and three white feet, $15 \frac{1}{4}$ hands high, and weighs 985 pounds, foaled 
May 17,1871 , bred by H. N. Howard, Skowhegan, Me., got by Gen. Knox, dam, by a horse bred in Nova Scotia, said to be by a Black Hawk horse, and out of a thoroughbred imported mare, $2 \mathrm{~d}$ dam, by the Allen horse. Royal Tanner was purchased by Charles Shaw \& Son, Detroit, Me.

\section{DUKE OF WELLINGTON.}

Roan stallion, 16 hands high, and weighs 1250 pounds, foaled in 1867, bred by Joel Bean, Maysville, Aroostook county, Me., got by Tom Lang, dam, by Warrior.

\section{RANGER.}

Dark bay stallion, with black points, 15 hands high, foaled in June, 1869, bred by W. H. Rackliffe, Eastern, Aroostook county, Me., got by Tom Lang, dam, a Drew.

\section{AROOSTOOK KNOX.}

Bay stallion, with star in forehead, and one white hind foot, foaled June 26, 1867, bred by Eben Trafton, Masardis, Aroostook county, Me., got by Gen. Knox, dam, Mathison mare, brought from Prince Edward's Island.

\section{TOM LANG, JR.}

Blood bay stallion, with black points, $16 \frac{1}{4}$ hands high, and weighs 1125 pounds, foaled June 10, 1868, bred by Samuel W. Collins, Caribou, Aroostook county, Me., got by Tom Lang; dam, a Messenger, grand dam by Old Cannon Ball. Owned by Samuel Caughey, Lyndon, Me.

\section{LEDO.}

Black stallion, 16 hands high, and weighs 1200 , foaled 
in June, 1868, owned by William B. Davis, Jefferson, Me., got by Uncle Shube, by Gen. Knox, dam, by an imported thoroughbred.

\section{EMPEROR WILLIAM.}

Bay stallion, with black mane and tail, 16 hands high, and weighs 1050 pounds, foaled in May, 1867, owned by C. H. \& J. M. Skinner, St. Albans, Me., got by Gen. Knox, dam, Lady Hollis, a pacing mare from Mass., said to have paced in 2.22 .

Emperor William trotted a half mile on the Hartland track, with but little training, in 1.20, in Oct., 1871.

\section{FLYING CLOUD.}

Black stallion, 16 hands high, and weighs 1100 pounds, foaled in June, 1865, owned by Geo. A. Bragg, North Carmel, Me., got by Black Sultan, dam, a Black Hawk mare.

\section{GEN. LEF.}

Mahogany bay stallion, with white hind feet, star and stripe in face, foaled in 1869, owned by Granville Hackett, Freeman, Me., got by Larkin's Gen. Knox, jr., dam, by the Sandy River horse.

\section{TROUBLESOME KNOX.}

Black stallion, with no white marks, foaled May 22, 1869, owned by G. A. Bragg, North Carmel, Me., got by Flying Cloud, dam, Black Hawk and Messenger. 


\section{CARRABASSETT.}

Black stallion, $15 \frac{1}{2}$ hands high, foaled MIay 5, 1871, owned by Hapgood \& Townsend, North Anson, Me., got by Norridgewock, by Gen. Knox, dam, an English mare.

\section{BISMARCK, JR.}

Brown stallion, 15 hands high, foaled June 20, 1870, owned by A. \& T. M. Waugh, Starks, Me., got by Howe's Bismarck, dam, of Messenger descent.

\section{BROWN BILLY.}

Brown stallion, with small star in forehead, and spot on nose, foaled May 11, 1871, owned by M. O. Dean, East Madison, Me., got by Gen. Knox, dam, by Rising Sun.

\section{BROWN BEN.}

Brown colt, foaled June 28, 1869, owned by Geo. F. Moore, Anson, Me., got by Norridgewock, dam, by the Norton horse, by Old Eaton.

\section{BLACK MONITOR, FORMERLY HIND'S KNOX.}

Black stallion, with star in forehead and spot on nose, and white hind feet, $15 \frac{3}{4}$ hands high, and weighs 1075 pounds, foaled June 10,1869, owned by S. H. Hinds \& Son, Salem, Me., got by Gen. Knox, dam, English and Eaton.

\section{RELIANCE.}

Bay stallion, with star in forehead, and two white hind feet, $1 \tilde{\sigma}^{\frac{3}{4}}$ hands high, foaled May 13,1870 , owned by $\mathbf{R}_{\text {, }}$ 
O. Conant, Portland, Me., got by Gilbreth Knox, dam, of Messenger descent.

\section{GILBRETH PRINCE.}

Dapple bay stallion, foaled June 12, 1871, owned by Hiram Reed, Augusta, Me., got by Gilbreth Knox, dam, by Gen. McClellan.

\section{YOUNG GILBRETH KNOX.}

Mahogany bay stallion, with black points, $16 \frac{1}{2}$ hands high, and weighs 1200 pounds, owned by Brown \& Hilton, North Anson, Me., got by Gilbreth Knox, dam, a thoroughbred mare, bred in Kentucky.

\section{AMERICAN KNOX,}

Black stallion, foaled July 15, 1871, owned by Geo. H. Bailey, Woodford's Corner, Me., got by Gen. Knox, dam, by Gile horse, by Lang's Telegraph, out of the Cahill mare. American Knox, dam, out of the Stewart mare, by Witherell.

\section{SANDY RIVER BOY.}

Bay colt, with black mane and tail, and star in forehead, foaled in June, 1871, owned by J. W. Moore, Starks, Me., got by Gen. Knox, dam, by Rising Sun.

\section{BARNEY.}

Knox stallion, $15_{\frac{1}{2}}$ hands high, and weighs 1150 pounds, fonled in 1865, owned by F. A. Dore, Skowhegan, Me., got by Gen. Knox, dam, a Vermont mare. 


\section{IRISH MAC.}

Dark bay stallion, with black points, $16 \frac{3}{4}$ hands high, and weighs 1175 pounds, foaled in 1866 , bred by Jerry McCarthy, of Pittsfield, Me., got by Gen. Knox, dam, a Drew mare. . Owned by Gorham A. Rowe, Canaan, Me.

\section{ROYAL GEORGE.}

Dapple bay stallion, with black points, $15 \frac{3}{4}$ hands high, and weighs 1085 poinds, foaled in June, 1869, owned by Seth Parlin, of Norridgewock, Me., got by Norridgewock, dam, a Tiger mare.

\section{DREW'S KNOX.}

Black stallion, with white spot on one hind foot, $15 \frac{1}{2}$ hands high, and weighs 1000 pounds, foaled July 4, 1870, bred by. Eri Drew, Pishon's Ferry, Me, got by Gen. Lightfoot, by Gen. Knox, dam, of Messenger descent.

\section{TOZIER'S ' KNOX.}

Black stallion, with white star in forehead, snip on nose and left hind heel white, $15 \frac{3}{4}$ hands high, and weighs 1175 pounds, foaled June 23, 1867, owned by O. C. Tozier, Anson, Me., got by Gen. Knox, dam, said to be of Messenger descent.

\section{INDEPENDENT GENERAL KNOX.}

Dark chestnut stallion, weighs 1050 pounds, foaled July 4, 1863, bred by Dean E. Reed, Madison, Me., got by Gen. Knox, dam, of Messenger descent.

\section{BARTLETT'S KNOX.}

Black stallion, 15 hands high, foaled June.11, 1870, bred 
by Josiah D. Bartlett, North New Portland, Me., got by Gen. Knox, dam, by Atkinson horse, he by Young Indian Chief.

\section{SAGADAHOC.}

Black stallion, 16 hands high, and weighs 1075 pounds, foaled May 22, 1863, bred by T. B. Reed, Bowdoinham, Me., got by Gen. Knox, dam, of Messenger descent. He was subsequently purchased by Wm. \& James Sampson, Bowdoinham, Me. No public record.

\section{UNCLE SHUBE.}

Formerly known as Wier's Knox; chestnut stallion, with star in forehead, 163 hands high, and weighs 1200 pounds, foaled in 1861, bred by David Wier, Vassalboro', Me., got by Gen. Knox, dam, of Messenger descent. He got a record of 2.50, as a four-year-old, which is his only public record. In May, 1871, Wier sold him to H. R. Butterfield, of East Vassalboro'.

\section{MINOT.}

Dark brown stallion, with black points, and no white marks, foaled June 9, 1868, bred by S. R. Bridgham, Hebron, Me., got by Gen. Knox, dam, of Morgan descent.

Mr. Bridgham sold him, when three years old, to Lon Morris, of Boston, for over $\$ 2000$.

\section{WHALEBONE KNOX.}

Dark bay stallion, with black points, and star in the forehead, $15 \frac{3}{4}$ hands high, and weighs about 1000 pounds, foaled in May, 186t, bred by Newman Whittier, Rome, Me., got by Gẹn. Knox, dam, by Pollard Morgan. Whit- 
tier sold him, when four months old, to Morrison Chandler, of Belgrade, Me. Chandler sold him, when two years old, to B. F. Fairbanks, then of West Gardiner, now of Winthrop.

\section{WELLINGTON KNOX.}

Blood bay stallion, 15: hands high, and weighs 1000 pounds, foaled in 1866, owned by Nelson Herrin, Houlton, Me., got by Gen. Knox, dam, by Chandler's Moscow, he by Old Moscow, Wellington Knox being full brother to Tom Lang.

\section{LARKIN'S GEN. KNOX, JR.}

Mahogany bay stallion, with black points, $15 \frac{1}{4}$ hands high, foaled June 12, 186t, bred by K. Larkin, Farmington, Me., got by Gen. Knox, dam, Lady Perham, Eaton and Messenger descent.

In 1872 he stood a part of the season at Canton Point. On the 10th of June, while Mr. Larkin was on his way from Farmington to Canton, with him, he was taken sick, and died at Wilton.

\section{COLONEL LANG.}

Steel gray stallion, $15 \frac{3}{4}$ hands high, and weighs 1050 pounds, foaled in 186-, bred by Geo. Freeman, of China, Me., got by. Gen. Knox, dam, of Messenger descent. Freeman sold him to Horace Nelson, and he to Lon Morris, of Boston, who has refused $\$ 5000$ for him. He is said to have trotted a mile in 2.38 .

\section{HOWE'S BISMARCK.}

Black stallion, $16 \frac{1}{3}$ hands high, and weighs 1200 pounds, 
foaled in 1S63, bred by T. S. Lang, Vassalboro, Me., got by Gen. Knox, dam, of Messenger descent. Col. Lang sold him, when a weanling, to James Howes, of New Sharon. At the State Fair, in 1870, he trotted in 2.40, and was awarded the first premium for stallions for general use under eight years old.

\section{BLACK STRANGER.}

Black stallion, with small star in forehead, 17 hands high, and weighs 1320 pounds, foaled May 20, 1866, bred by James Hussey, Getchell's Corner, Me., got by Uncle Shube, formerly. called Wier's Knox, dam, by Homan's Messenger.

\section{BONNYDOON.}

Dark brown stallion, with two white feet, and narrow stripe in face, 16 hands high, foaled June 20, 1868, bred by Charles A. Frost, Corinna, Me., got by Black Sultan, dam, of Morgan descent.

Has been awarded three first premiums at West Penobscot Agricultural Society Fairs.

\section{STARR KING.}

Dark brown stallion, with star in forehead, and one white hind foot, foaled May 30, 1871, bred by William Chamberlain, Belgrade, Me., got by Col. Kling, dam, by Wamsutter, he by Sherman Black Hawk. Chamberlain sold him when four months old to E. W. Webb, Augusta, Me.

\section{ROBERT BONNER.}

Black stallion, with star in forehead and stripe on nose, 
foaled May 25, 1871, bred by Charles H. Hoxie, No. Fairfield, Me., got by Gen. Knox, dam, by Gen. McClellan.

In April, 1873, Mr. Hoxie sold a one-half interest in Robert Bonner to Mr. 'Bowman. At the Maine State Fair of 1873 , he took the first premium in his class.

\section{MAJOR KNOX.}

Bright bay stallion with black points, and white star in forehead, 15 hands high and weighs 900 pounds, foaled in April, 1865, bred by John M. White, Windham, Me., got by Gen. Knox, dam, Jeanette Rand, by Harris' Hambletonian, her dam, an imported English mare, said to be thoroughbred.

\section{BLACK DUKE.}

Black stallion, with star in forehead and spot on nose, and off hind foot white, 15 hands $1 \frac{1}{2}$ inches high, foaled in 1870 , bred by Levi Rich, Brooks, Me., got by Black Sultan, dam, by Indian Chief, grand dam, of Morgan descent.

\section{FINANCE.}

Bay colt, foaled June 4, 1872, owned by C. H. Skinner, St. Albans, Me., got by Emperor William, dam, a Witherell mare.

\section{HENRY WILSON.}

Sorrel colt, foaled in 1872, owned by C. H. Skinner, St. Albans, Me., got by Emperor William, dam, a Witherell mare. 
GEN. IIOWE, G.

Dark brown or black stallion, with star in forehead, and very little white on both hind feet, $16 \frac{1}{2}$ hands high, and weighs 1260 pounds, foaled in 1868, owned by M. W. Norton, North New Portland, Me., got by Gell. Knox, dam, a Black Morgan mare.

\section{STAR KNOX.}

Black stallion, with star in forehead, $15 \frac{1}{2}$. hands high, foaled in June, 1868, got by Ames' Knox, by Gen. Knox, dam, a Drew mare. Owned by C. H. \& C. Whitten, Lee, Me. Star Knox was awarded the first premiun at the North Penobscot Agricultural Society Fair, of 1872.

\section{GEN. DIX (BUSSEY'S).}

Dark bay stallion, 16 hands high, and weighs 1050 pounds, foaled in 1S68, bred by Benjamin Bussey, Dixmont, Me., got by Gen. Knox, dam, by the Burnet horse, by Old Drew.

\section{LEADER.}

Bay stallion, foaled in 1870 , owned by C. H. \& J. M. Skinner, St. Albans, Me., got by Gen. Knox, dam, by the Bachellor horse.

\section{WHIZ.}

Bay stallion, with black points, foaled June 15, 1870, owned by D. W. Emery, Somerset Mills, Me., got by "Uncle Shube," formerly Wier's Knox, dam, a Black Hawk. 


\section{WHIRLPOOL.}

Bay colt, with black points, star in forehead and spot on nose, and one white hind foot, foaled May 29, 1870, bred by Henry K. Sawyer, South Norridgewock, Me., got by Skowhegan Boy, by Gen. Knox, dam, Aunt Lucy.

\section{DUKE ALEXIS.}

Black colt, with star in forehead, spot on nose, and two white hind feet, foaled May 10, 1872, bred by Joseph Davis, Addison, Me., got by Gilbreth Knox, dam, an English mare.

\section{OLD PROBABILITY.}

Dark bay stallion, with black points, foaled June 20, 1870, owned by H. T. Walker, Monmouth, Me., got by Monmouth Knox, dam, by the Slinchfield horse.

\section{PLUTO.}

Dark bay colt, foaled May 28, 1871, owned by C. P. Thomas, Newburgh, Me., got by Young Knox, by Black Sultan, dam, Mr. Thurlough's mare Flora.

\section{FRED DOUGLASS.}

Black stallion, 16 hands high, and weighs 1175 pounds, foaled in 1869, owned by Mr. F. A. Butterfield, East Wilton, Me., got by Howe's Bismarck, dam, a bay mare of Morgan descent, formerly owned by C. J. Talbot.

\section{ROYAL KNOX.}

Black stallion, foaled in May, 1870, bred by H. A. Archer, Fairfield Centre, Me., got by Gen. Knox, dam 
(the dam of Lady Fairfield), of Messenger descent. Archer sold him in. 1873 to Amos Gerald, of Kendalls Mills.

WOODFORD KNOX, FORMERLY GOLD DROP.

Bay stallion with black points, and star in forehead, foaled in May, 1871, bred by H. A. Archer, Fairfield Centre, Me., got by Gen. Knox, dam, Shoo Fly, by Rising Sun. Archer sold him in 1873 to Amos Gerald, of Kendalls Mills, and he to Geo. H. Bailey, Woodfords, Me.

\section{HIA WATHA.}

Black stallion, foaled June 25, 1871, bred by J. F. Longley, Plymouth, Me., got by Brackett's Knox, Jr., dam, a Drew.

\section{INDEPENDENT BOY.}

Colt, foaled July 4, 1871, bred by A. G. Thurlow, So. Poland, Me., got by Gen. Knox, dam, by Hampton.

\section{FLEETFOOT.}

Black stallion, with star in forehead, and stripe in face, foaled May 1, 1870, bred by H. N. Howard, Skowhegan, Me., got by Gen. Knox, dam, Lady Loomis, by the Beal horse.

He was subsequently purchased by C. A. Fuller, Fairfield, Me.

\section{COL. KLING.}

Dark chestnut stallion, 16 hands high, and weighs 1035 pounds, foaled in May, 1864, bred by J. M. Chandler, 
Belgrade, Me., got by Gen. Knox, dam, by Morgan Mesenger.

\section{EMPIRE.}

Dark bay colt, with black points, star in forehead, and a little white on left hind foot, 16 hands high, and weighs 1015 pounds, foaled May 5, 1869, owned by James S. Morrill, Albion, Me., got by Gen. Knox, dam, of English blood.

\section{JOHNNY SCHMOKER.}

Gray colt, with black points, foaled May 1, 1872, owned by Ivory C. Low, Fairfield, Me., got by Honest John, dam, Fannie, by Witherell.

\section{HONEST JOHN (JONES').}

Gray colt, foaled May, 1871, owned by Rodney Jones, Fairfield Centre, Me., got by Honest John, by Gilbreth Knox, dam, by Flying Eaton.

\section{BOSTON CHARLEY.}

Dark bay colt, with black points, star in forehead and diamond on nose, foaled in 1873 , bred by B. R. Hunt, Unity, Me., got by Pillsbury's Knox, dam, May-day, by Imported Annfield.

\section{MONTGOMERT KNOX.}

Chestnut stallion, 16 hands high, and weighs 1000 pounds, foaled in 1869, bred by Leonard Montgomery, Boothbay, Me., got by Uncle Shube, dam, Messenger. Owned by S. H. Fuller, Damariscotta Mills, Me. 


\section{LEADAWAY.}

Light bay stallion, star in forehead, and one white hind foot, foaled in June, 1870, owned by Oliver Whitten, of Unity, Me., got by Uncle Shube, dam, of Morgan descent.

\section{STARLIGHT.}

Chestnut stallion, with star in forehead, and white stripe in face, foaled in 1869 , owned by James Haley, Frankfort, Me., got by the Curtis horse, by Gen. Sherman, and he by Gen. Knox, dam, unknown.

\section{SLASHER.}

Black stallion, $16 \frac{1}{2}$ hands high, and weighs 1000 pounds, foaled in 1866, owned by A. F. Stevens, East Dixmont, Me., got by Black Sultan, dam, of Messenger descent.

\section{ROLLINS KNOX.}

Light bay stallion, with black mane and tail, $15 \frac{1}{2}$ hands . high, and weighs 1000 pounds, foaled in June, 1867, bred by Israel L. Rollins, of Garland, Me., got by Gen. Knox, dam, of Messenger descent.

\section{DICK KNOX.}

Dark chestnut stallion, with star in forehead, and stripe on nose, and left hind foot white, 15 hands high, foaled August 1, 1869, bred by D. C. Tozier, Waldo, Me., got by Gen. Knox, dam, of English blood.

\section{COOLOO.}

Dark bay stallion, with black points, $1 \overline{5}_{2}^{\frac{1}{2}}$ hands high, and weighs 1025 pounds, foaled in June, 1867, bred by 
Welcome Haskell, of New Vineyard, Me., got by Howe's Bismarck, dam, a gray mare, of Messenger descent. $\mathrm{He}$ was purchased by Edward Savage, of Dexter, and Mark Emery, jr., of North Anson, Me.

\section{MOHAWK.}

Red roan stallion, with black points, $15 \frac{1}{2}$ hands high, and weighs 1060 pounds, owned by Albert Gerrish, Milford, Me., foaled August 1, 1866, got by Ames' Knox, dam, a Messenger mare.

\section{MAJOR KNOX.}

Light bay stallion, with black points, foaled June 25, 1870, owned by Fitz Henry A. Boody, of Jackson, Me., got by Waldo Chief, by Gen. Knox, dam, of Messenger descent.

\section{DANIEL WEBSTER.}

Black stallion, weighing 1300 pounds, foaled in 1866, bred by Joseph Curtis, Winterport, Me., got by Gen. Sherman, by Gen. Knox, dam, of French and English blood.

\section{T. S. LANG, JR.}

Gray stallion, weighing about 900 pounds, foaled in June, 1869, owned by C. C. Brown, Clinton, Me., got by T. S. Lang, by Gen. Knox, dam, Messenger and Morgan, grand dam, Phantom, by Grover's Messenger.

\section{R. E. LEE.}

Black stallion, with brown points, and small star in

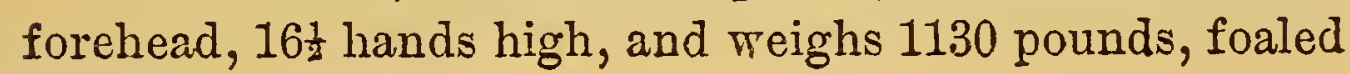


in June, 1866, owned by N. M. Prescott, Clinton, Me., got by Black Sultan, dam, by Hiram Drew.

\section{SANFORD KNOX.}

Black stallion, with some white in face, $15 \frac{3}{4}$ hands high, foaled June 23, 1869, bred by Allen Lambard, Augusta, Me., got by Gen. Knox, dam, Lady Sanford.

\section{KENNEBEC CHIEF.}

Dark bay stallion, with black points, foaled May 16, 1870, bred by Isaac Decker, Clinton, Me., got by Gilbreth Knox, dam, by Hiram Drew.

\section{WEST GARDINER BOY.}

Dark chestnut stallion, $15 \frac{3}{4}$ hands high, and weighs 1030 pounds, foaled in 1868, owned by E. C. Douglass, West Gardiner, Me., got by Whalebone Knox, dam, of Morgan descent.

\section{LITTLE FRED (OTIS').}

Dark bay stallion with black points, $15 \frac{1}{4}$ hands high, foaled in 1870, bred by Nathaniel Tuttle, Smithfield, Me., got by Gen. Knox, dam, by Blaisdell Messenger. Owned by B. F. Otis, West Waterville, Me.

\section{NEPTUNE.}

Blood bay stallion with black points, star in forehead, 16 hands high, and weighs 1055 pounds, foaled August 6, 1869, bred by George F. Rowell, Monmouth, Me., got by Monmouth Knox, dam, by Black Morgan. 


\section{BILLY MOUNTFORT.}

Dark bay stallion, with star in forehead, and one white hind foot, foaled in June, 1870, bred by Mr. Mabury, of Casco, Me., got by Phil Sheridan, dam, of Morgan descent. Owned by Albert Mountfort, of Bryant's Pond, Me.

\section{YOUNG KNOX, JR.}

Dark bay stallion with black points, $16 \frac{1}{4}$ hands high, and weighs 1240 pounds, foaled in 1S66, bred by Mr. Howard, of Skowhegan, dam, a Messenger mare. Owned by Coffin \& Hutchins, New Portland, Me.

[Note.-The above description and pedigree was taken from the records in the Somerset Registry of Deeds, in which the name of the sire of Young Knox, Jr., does not appear.-J. W. T.]

\section{COL. KNOX.}

Black stallion, with star in forehead, and white on two feet, $15 \frac{1}{2}$ hands high, and weighs 1200 pounds, foaled June 24, 1867, bred by Chandler Baker, Bingham, Me., got by Independent Knox, by Gen. Knox, dam, of Margan descent.

\section{BEN HAMPTON.}

Black stallion, $15 \frac{1}{2}$ hands high, and weighs aboul 1050 pounds, foaled June 14, 1865, owned by Enoch Weston, IIadison, Me., got by Gen. Knox, dam, Witherell.

\section{YOUNG GENERAL KNOX.}

Gray stallion, $15 \frac{1}{2}$ hands high, and weighs 1050 pounds, foaled July 4, 1867, bred by Thomas W. Downs, Har- 
mony, Me., got by Uncle Shube, dam, of Messenger descent.

\section{KNOX BOY (ClEAvEland's).}

Black stallion, with star in forehead, 15 hands, $3 \frac{1}{2}$ inches high, and, weighs 1100 pounds, foaled May 20, 1861, bred by C. Cleveland, got by Gen. Knox, dam, Fanny, a half-bred mare.

\section{DONNYBROOK.}

Black stallion, 16 hands high, and weighs 950 pounds, foaled May 12, 1868, bred by John H. Tucker, Fairfield, Me., got by Gilbreth Knox, dam, unknown.

\section{NEW PORTLAND BOY.}

Dark bay stallion with black points, stripe in face, and white hind feet, $15_{\frac{1}{2}}$ hands high, and weighs 950 pounds, foaled June 3, 1870, got by Hardy's Knox, dam, by Beals horse.

\section{MORRELL KNOX.}

Black stallion, $15 \frac{3}{4}$ hands high, and weighs 1130 pounds, foaled in 1865, owned by Henry J. Morrell, West Waterville, Me., got by Gen. Knox, dam, of Morgan and Messenger descent.

\section{COOK COIT.}

Dark bay stallion, 15 hands high, and weighs about 900 pounds, foaled June 3, 1870, bred by Eli Cook, New Sharon, Me., got by Howes' Bismarck, dam, of Morgan descent. 


\section{HARDY'S KNOX.}

Brown black stallion, with star in forehead, spot on nose and white hind feet, 16 hands high, and weighs 1175 pounds, foaled May 18, 1866, bred by Eliphalet J. Hardy, East Wilton, Me., got by Gen. Knox, dam, by Bonaparte, by Tamaraska.

\section{WHALEBONE.}

Bay stallion, with black points, and weighs 1162 pounds, foaled June 24, 1868, bred by IV. T. Hoar, Rangeley, Me., got by Larkin's Gen. Knox, jr., dam, of Morgan and Messenger descent.

\section{HILLMAN'S KNOX.}

Dark bay stallion, weighing 1020 pounds, foaled May 25, 1869, bred by Gilbert R. Hillman, New Vineyard, Me., got by Larkin's Gen. Knox, jr., dam, of Messenger descent, got by the Everett horse.

\section{BISMARCK, JR.}

Dapple gray stallion, $15_{\frac{1}{2}}^{\frac{1}{2}}$ hands high, and weighs 1022 pounds, foaled in 1869 , bred by W. P. Haskell, New Vineyard, Me., got by Howe's Bismarck, dam by a Stone Messenger colt.

\section{CROTWN PRINCE.}

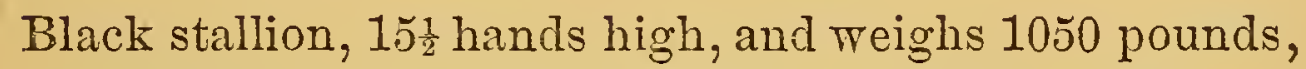
foaled April 5, 1866, bred by Ira D. Sturgis, Augusta, Me., got by Gen. Knox, dam, thoroughbred. He was awarded the first premium at the Maine State Fair, of 1873 , for stallions under eight years of age. 


\section{MILINOKETT.}

Bay stallion, with star in forehead, and spot on nose, foaled May, 1870, bred by H. N. Howard, Skowhegan, Me., got by Gen. Knox, dam, by Beal horse, he by Flying Eaton.

He was subsequently purchased by C. A. Fuller, Fairficld Centre, Me.

\section{REX.}

Black stallion, with star in forehead, and white hind feet, 16 hands high, and weighs 1000 pounds, foaled June 23, 1869, owned by L. F. Stewart, Etna, Me., got by Midnight, dam, of Morgan and Messenger descent.

\section{FAIRFIELD KNOX (CrLLEY'S).}

Black colt, foaled March 23, 1871, bred by J. A. Cilley, Fairfield, Me., got by Gilbreth Knox, dam, thoroughbred.

\section{GEN. FRANTLIN.}

Black stallion, with white hind feet, 16 hands high, and weighs 1100 pounds, foaled in 1869, bred by T. Jennings, Farmington, Me., got by Larkin's Gen. Knox, jr., dam, by Beals horse.

Jennings sold him, when one year old, to Dr. P. Dyer, of Farmington.

\section{BUSSEY'S KNOX.}

Dark bay stallion, 16 hands high, and weighs 1050 pounds, foaled in 1868, bred by Benjamin Bussey, Dixmont, Me., got by Gen. Knox, dam, Drew and Messenger. 


\section{RONDO INOX.}

Red roan stallion, $15 \frac{3}{4}$ hands high, and weighs 1150 pounds, foaled July 4, 1868, bred by J. D. Prescott, Farmington, Me., got by Howe's Bismarck, dam, by Young Indian Chief. Prescott sold him when a weanling to I. S. Jacobs, Farmington, Me.

\section{HONEST JOYIN (BRIGGS').}

Chestnut stallion, $15 \frac{1}{4}$ hands high, and weighs 1000 pounds, foaled in 1867, bred by John M. Briggs, Parkman, Me., got by Logan (now called Jules Jergensen), dam, a white Arabian mare(?) known as the Harrington mare.

\section{LEXINGTON.}

Black stallion, foaled about 1863, bred by Ira D. Sturgis, Augusta, Me., got by Gen. Knox, dam, an English mare. Mr. Sturgis sold him to Mr. Monroe, of Lexington, Mass. Record 2.44.

\section{COL. ELLSWORTH.}

Formerly known as the Clark horse, of China, Me., got by Gen. Knox, dam, by Homan's Messenger, 2d dam, by China Farmer. Sold to Joseph Baker, East Boston, Mass., and afterwards taken to Indiana.

\section{HIRAM.}

Black stallion, $15 \frac{1}{2}$ hands high, and weighs about 1000 pounds, foaled July 26, 1868, bred by Karrison Clements, Belgrade, Me., got by the Hallet horse, of Waterville, he by Gen. Knox, dam, of Messenger descent. Owned by Eben N. Perry, Cape Elizabeth, Me. 


\section{WHIR.LTIND.}

Bay staliion, with black points, star in forehead, and white heels behind, foaled June 10, 1873, owned by William J. Haynes, Smithfield, Me., got by Gen. Lightfoot, by Gen. Knox, dam, Jessie Drew, 2d dam, by Pishon horse.

\section{YOUNG KNOX.}

Black stallion, with star in forehead, foaled in July, 1871, owned by J. A. Flagg, Benton, Me., got by Gen. Knox, dam, by a son of Old Hiram Drew.

\section{KING PHILIP.}

Mahogany bay stallion, with star in forehead, spot on nose, and two white hind feet, foaled August 4, 1871, bred by William Jepson, North Vassalboro', Me., got by Gen. Knox, dam, by Old Eaton.

\section{ENTERPRISE (MILLER'S).}

Black stallion, 15 hands high, and weighs about 900 pounds, foaled in 1S68, bred by J. C. Miller, Wilton, Me., got by Larkin's Gen. Knox, jr., dam, by Black Hawk Napoleon, he by Ford's Black Hawk, by Vermont Black Hawk.

\section{COUNT MONTE CHRISTO.}

Dark chestnut stallion, with no white marks, $15 \frac{3}{4}$ hands high, foaled in 1867, owned by Nathan Cloudman, Stetson, Me., got by Gen. Knox, dam, by Cloudman. 


\section{BLACKWING.}

Black stallion, foaled May 22, 1870, owned by William Smith, East Exeter, Me., got by Flying Cloud, dam, Black Hawk.

\section{CHAMPION KNOX.}

Black stallion, with star in forehead, spot on nose, and one white hind foot, foaled June 20, 1870, bred by G. A. Bragg, North Carmel, Me., got by Gen. Knox, dam, Black Hawk and Messenger.

\section{GILBRETH KNOX, JR.}

Black stallion, with white ankles behind, foaled in 1870,.bred by Mr. Foss, of Albion, Me., got by Gilbreth Knox, dam by Witherell. Foss sold him to Amos Gerald, of Fairfield, Me., and he to Gideon Ellis, of Canton.

\section{VOLTAIRE.}

Bay colt, with four white feet, star in forehead, and spot on nose, foaled in June, 1871, owned by George W. Cannon, Fairfield Centre, Me., got by Maine Slasher, dam, a Drew mare.

\section{LITTLEFIELD COLT.}

Sorrel colt, with star and stripe, and near forward foot white, foaled June 10, 1872, bred by J. M. Littlefield, of Abbott, Me., got by Emperor William, dam (the dam of Nellie Briggs), of the Defiance stock. Mr. Littlefield refused $\$ 450$ for the above colt, when four months old. 


\section{PRINCE ALBERT.}

Black colt, foaled in 1872, owned by C. H. Skinner, St. Albans, Me., got by Emperor William, dam, English.

\section{JOHN KNOX.}

Gray colt, foaled in 1871, owned by C. H. Skinner, St. Albans, Me., got by Skinner's Knox, by Gen. Knox, dam, Maggie, a trotting mare, of Messenger descent.

\section{HONEST JOHN, JR.}

Gray colt, foaled Sept. 14, 1871, owned by J. H. Getchell, Somerset Mills, got by Honest John, by Gilbreth Knox, dam, of Messenger descent.

\section{J. H. GILBRETH.}

Bay colt, with black points, foaled May 15, 1S72, owned by J. H. Getchell, Somerset Mills, got by Gilbreth Knox, dam of Messenger descent.

\section{JOAQUIN.}

Black colt, foaled July 31, 1873, bred by Luke Hilton, Skowhegan, Me., got by Black Sultan, dam, Morgan and English.

\section{BRUTUS.}

Bay colt, foaled May 1, 1873, orned by A. P. Mero, Union, Me., got by Gen. Warren, by Gen. Knox, dam, a thoroughbred mare, brought from the South.

\section{MIDDY MORGAN.}

Bay colt, with black points, foaled May 9,1871 , bred by 
Granville Hackett, West New Portland, Me., got by Larkin's Gen. Knox, jr., dam by Sandy River horse. .

\section{EASTEPN QUEEN.}

Dark bay mare, almost brown, with white star in forehead, $15 \frac{3}{4}$ hands high, and weighed 1070 pounds at three years of age, foaled April 28, 1870, bred by Ivory Low, of Fairfield, Me., got by Gilbreth Knox, dam, by Old Witherell. Low sold her, in the Spring of 1870 , to J. M. Fogg, of Fairfield, and at the Maine State Fair of 1873 , at Bangor, she won the race for three-year-olds in two straight heats, the fastest being 3.01 .

\section{INDEPENDENT KNOX (CROCKETT'S).}

Brown colt, with star in forehead, and one white hind foot, foaled July 4, 1871, bred by Robert Crockett, Rockland, Me., got by Gen. Berry, dam, an imported thoroughbred English mare.

\section{COBBOSSEE KNOX.}

Dark brown stallion, with tan muzzle and flanks, star in forehead, white spot on upper lip, and on one hind foot, foaled Sept. 2, 1871, bred by C. K. Edwards, West Gardiner, Me., got by Gen. Knox, dam, by Thunder Cloud, he by Black Hawk Telegraph, $2 d$ dam, by Rising Sun, 3d dam, by Indian Chief.

\section{INDEPENDENT KNOX (WILSON'S).}

Dark bay colt, with star in forehead, small white spot on nose, and one white hind foot, foaled July 4, 1871, owned by Isaac Wilson, Bowdoinham, Me, got by Gen. Knox, dam, a Vermont Morgan mare. 


\section{METACOMET.}

Dark brown, or black, stallion, with small star in forehead, 16 hands high, foaled May 12, 1S71, bred by C. Butman, Esq., Plymouth, Me., got by Black Sultan, dam, by Old Drew.

Mr. Butman sold him to S. B. Thayer, of Plymouth, and A. L. Burrill, of Nerport.

\section{FREDERICK CHARLES.}

Mahogany bay stallion, foaled June, 1869, got by Gen. Knox, dam, Hambletonian, brought from New York, by Abner Barrows, Esq., colt now owned by F. R. Webber, St. Albans, Me.

\section{KITTY.}

Black mare, with star in forehead, foaled June, 1869, bred by F. R. Webber, St. Albans, Me., got by Gen. Knox, dam, Drew.

\section{FLYAWAY.}

Dark brown filly, with stipe in face, foaled 1870, bred by F. R. Webber, St. Albans, Me., got by Gen. Knox, dam (the dam of Kitty), Drew.

\section{QUEEN VICTORIA.}

Black mare, foaled July, 1869, owned by F. R. Webber, St. Albans, Me., got by Gen. Knox, dam, a mare of Black Hawk descent.

\section{DON PEDRO.}

Brown colt, foaled May, 1S72, bred by F. R. Webber, 
St. Albans, Me., got by Emperor William, dam, pedigree unknown.

\section{ECLAIR.}

Black stallion, foaled 1870 , bred by Wm. \& A. S. Parker, Skowhegan, Me., got by Gen. Knox, dam, by the Merrow horse.

\section{GEN. GRANT (GILBERT's).}

Gray colt, foaled 1869, owned by P. S. Gilbert, Manchester, Me., got by Shoo Fly, by Gen. Knox, dam, by Indian Chief.

\section{FRANSEER.}

Dark bay stallion, with black points, $15_{\frac{1}{2}}$ hands high, and weighs 1050 pounds, foaled in July, 1870, owned in Litchfield, Me., got by Howe's Bismarck, dam, by Tufts' Wildcat.

\section{SHAW'S KNOX.}

Black stallion, 16 hands high, and weighs 1000 pounds, foaled in 1871, owned by John Shaw, near East end of Kennebec bridge, Augusta, Me., got by Uncle Shube (formerly Wier's Knox), dam, by a son of Geo. M. Patchen.

\section{NORRIDGEWOCK BOY.}

Black stallion, $16 \frac{1}{2}$ hands high, and weighs 1100 pounds, foaled in 1870, owned by Seth Parlin, Norridgewock, Me., got by the Townsend horse, by Gen. Knox, dam, of Messenger descent. 


\section{ROBINSON KNOX.}

Mahogany bay stallion, with black points, $15 \frac{1}{2}$ hands high, and weighs 1060 pounds, foaled June 30, 1870, bred by Isaac Robinson, East Vassalboro', got by Gen. Knox, dam, of English blood.

\section{BISMARCK (GREENLEAF's).}

Sorrel stallion, with white stripe in the face, $15 \frac{1}{2}$ hands high, and weighs 900 pounds at two years old, foaled May 29, 1872, owned by O. W. Greenleaf, Starks, Me., got by Howe's Bismarck, dam, of Morgan descent.

\section{FIYING ROMAN BOY.}

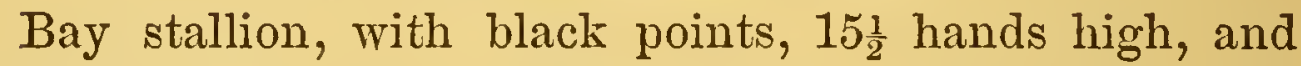
weighs 950 pounds, foaled in 1870, owned by L. H. Stevens, Jamaica Point, Rome, Me., got by Waterville Boy, by Gen. Knox, dam, of Morgan descent.

\section{VALLEY KNOX.}

Bay colt, with black points, foaled May 24, 1873, bred by C. M. Holland, Canton Point, Me., got by Larkin's Gen. Knox, jr., dam, by Young Brandywine.

\section{HIRAM WOODRUFF.}

Bay stallion, with black points, foaled June 12, 1872, bred by Hiram A. Ellis, Canton Point, Me., got by Larkin's Gen. Knox, jr., dam, by Young Brandywine.

Sold, when four months old, to C. M. Holland, Canton Point.

\section{ANDROSCOGGIN KNOX.}

Black colt, foaled in May, 1873, bred by Granville 
Childs, Canton Point, Me., got by Larkin's Gen. Knox, jr., dam, Nellie Gray, a noted breeding mare, owned by Mr. Childs, pedigree unknown.

\section{DREW KNOX.}

Black stallion, foaled May 25, 1370, bred by L. D. Soper, Poland, Me., got by Phil. Sheridan, dam, a Drew mare.

\section{LEWISTON KNOX.}

Chestnut stallion, foaled in 1870, bred by Ai Brooks, of Lewiston, Me., got by Gen. Knox, dam, by Lewiston Boy. Owned by J. P. Norton, Lewiston, Me.

\section{DASHING CHARLIE.}

Black stallion, with star in forehead, $15 \frac{1}{2}$ hands high, foaled June 20, 1870, bred by Sidney H. W. Bragdon, Auburn, Me., got by Phil. Sheridan, dam, of the stock of the horse known as the French Leopard, of Connecticut.

\section{GENERAL LYON (LYON'S).}

Mahogany bay stallion, foaled Sept. 1, 1871, bred by A. J. Lyon, West Waterville, Me., got by Gen. Knox, dam, by an imported horse.

\section{COUNTRY GIRL.}

Sorrel mare, with narrow white stripe in face, $16 \frac{1}{2}$ hands high, and weighs 1100 pounds, foaled in 1867, bred by John Tibbetts, of New Sharon, Me., got by Bismarck, dam, a Hambletonian mare, brought from New York. When three years old she was purchased by William A. Whittier, Farmington Falls, Me. 


\section{PILLSBURY KNOX.}

Black stallion, with star in forehead, foaled in 1868 , owned by G. B. Pillsbury, Unity, Me., got by Gen. Knox, dam, by Bucephalus.

\section{SINGED CAT.}

Black mare, foaled in 1868, got by Gen. Knox, dam, a thoroughbred mare, by Archer Thorn. Now owned by G. B.Pillsbury, Unity, Me.

\section{STAVER.}

Dark brown stallion, with black points, and small white spot on upper lip, 15 hands high, foaled May 20, 1868, bred by Stephen Robinson, North Vassalboro', Me., got by Gen. Knox.

\section{REAL ESTATE.}

Black gray stallion, weighing 1050 pounds, foaled in May, 1870, owned by J. A. Flagg, Benton, Me., got by Gilbreth Knox, dam, by a son of Old Hiram Drew.

\section{PRINCE EDWARD.}

Bay colt, foaled April 18, 1872, bred by A. G. Thurlow, Sóuth Poland, Me., got by Phil. Sheridan, dam, of Morgan descent.

\section{LESLIE COLT.}

Dark bay gelding, with black points, and white hind feet, foaled in 1871, owned by Whitman Leslie, West Gray, Me., got by Phil. Sheridan, dam a Messenger mare, by Charter Oak. 
KNOX BOY (LEE's).

Chestnut colt, foaled in 1869, owned by Merrill Lee, Riverside, Me., got by Knox, jr., dam, by Hector.

\section{JEFF.}

Bay gelding, with white in face, and four white legs, foaled in 1869, owned by P. C. Whittier, Cornville, Me., got by Skowhegan Boy, by Gen. Knox, dam, by French Tiger.

\section{WORROMONTOGUS.}

Chestnut gelding, foaled June 6,1870 , bred by Alvah Gilman, Monmouth, Me., got by Whalebone Knox, dam, by Bonny's Young Eaton. Worromontogus was subsequently purchased by Gen. W. S. Tilton, Togus, Me.

\section{WINTHROP KNOX.}

Dark brown colt, with black points, and star in forehead, foaled June 7, 1873, owned by J. W. Vose, East Winthrop, Me., got by Col. Kling, dam, of Messenger descent.

\section{TOM PAYNE.}

Light gray gelding, 16 hands high, foaled June 7, 1867, owned by A. P. H. Heywood, Houlton, Me., got by Tom Lang, dam, a gray mare of Messenger descent.

\section{ARBUTUS.}

Brown filly, with stripe in face, foaled May 1, 1872, bred by H. M. Lander, Fairfield Centre, Me., got by Drummond Knox, dam, Kitty Wells, thoroughbred. 


\section{SHOOTING STAR.}

Sorrel colt, with star in forehead, foaled April 15, 1873, bred by H. M. Lander, Fairfield Centre, Me., got by Drummond Knox, dam, Kitty Wells, thoroughbred.

\section{MORRILL KNOX.}

Mahogany bay stallion, with black points, and small white star in the forehead, foaled May 3, 1871, bred by Peter Letourneau, West Waterville, Me., got by Gen. Knox, dam, by Winthrop Morrill.

\section{GOLD HUNTER.}

Bay stallion, with black points, and no white marks, foaled in 1870, bred by Mr. Dorge, Burnham, Me., got by Gen. Lightfoot, dam, a Drew mare. S. H. Jacobs, of Skowhegan, bought him in June, 1873.

\section{KNOX QUEEN.}

Dark bay mare, with black points, and star in the fore-

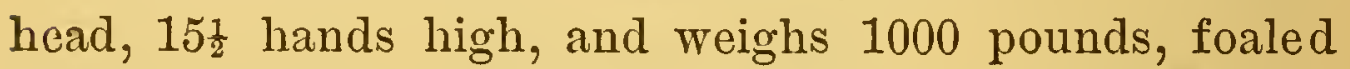
May 20, 1869, bred by S. F. Lyford, St. Albans, Me., got by Gen. Knox, dam, Lady Hamilton, with a record of 2.33 , over the Irartland track, in a race with Lady Fairfield.

\section{NELLIE KNOX.}

Filly, foaled July 13, 1873, owned by C. F. Carlton, Dexter, Me., got by Rollins Knox, by Gen. Knox, dam, by the Tewksbury horse, by French Tiger. 


\section{BUTTERBALL.}

Gray mare, $14 \frac{3}{4}$ handș high, and weighs about 900 pounds, foaled in 1864, bred by E. J. \& G. W. Lawrence, Fairfield, Me., got by Gen. Knox, dam, a white mare, by Homan's Messenger. Messrs. Lawrence sold her, in 1872 , to James Withee, of Winslow, for $\$ 1200$, and Withee sold her to New York parties for over $\$ 3000$. She is a strong and well-made mare, with a fine turn of speed. She won several races while owned in Maine. At Forest City Park, Portland, Me., Oct. 5, 1871, she won the fifth, sixth and seventh heats and race, beating Bull-ofthe-Woods (now Buffalo Bill), Phil. Sheridan, and Kittie Wild.

\section{PLYMOUTH ROCK.}

Bay gelding, 15 hands, $2 \frac{1}{2}$ inches high, and weighs 1175 pounds, foaled July 9, 1866, owned by C. Butman, Plymouth, Me., got by Black Sultan, dam, an English mare, from Prince Edward's Island. June 26, 1873, at Bangor, Me., he won the first race in which he ever started, beating a field of six horses, fastest heat $2.44 \frac{1}{4}$. After haying, during which he hauled fifty tons of hay, he went to Skowhegan and won the 2.44 race against six horses, trotting five heats without a break, winning the first in $2.45 \frac{1}{2}$, and the fifth in $2.40 \frac{1}{2}$. .

\section{TOMMY.}

Brown gelding, 15 hands high, foaled in 1868, bred by Oliver Dunnell, North Jay, Me., got by Larkin's Gen. Knox, jr., dam (the dam of Daniel Boone), pedigree unknown. Dunnell sold him, when four months old, and after having several different owners he become the prop- 
erty of J. C. Miller, of Wilton, when four years old. At the Lewiston Driving Park, in August, 1873, in a race he obtained a record of $2.42_{2}$.

\section{MYRA SHAW.}

Brown mare, with white ankles behind, 15 hands high, foaled June, 1867, bred by W. H. Mathews, Searsport, Me., got by Tom Lang, dam, pedigree not traced. Mathews sold her to O. M. Shaw, of Bangor, and he to Geo. H. Bailey, of Portland. In 1872 she obtained a record of 2.38 in a race at Lewiston, Me., and Mr. Bailey afterwards sold her to go West.

\section{HARRY SPANKER.}

Bay gelding, 15 hands high, foaled in May, 1865, bred by Edward Clements, Portland, Me., got by Gen. Knox, dam, Lady Gay Spanker. Clements sold him to Geo. H. Bailey, of Woodford's Corner, and he claimed for him the name of "Charles M. Thompson." When three years old he was sold to James Hanley, of Providence, R. I. Nov., 1873, at Providence, R. I., he won a race in $2.35 \frac{3}{4}$, $2.35,2.35$. He had won, previous to this race, a race at Springlield, Mass., for horses that never trotted for money, fastest heat $2.41 \frac{1}{2}$.

\section{BELLE HIGHT.}

Bay mare, with black points, and blaze in face, foaled in 1866, owned by E. W. Webb, Augusta, Me., got by Gen. Knox, dam, by Hiram Drew.

\section{BELLE KNOX.}

Dark bay mare, with no white marks, $15 \frac{3}{4}$ hands high, 
foaled in 1867, bred by $\mathrm{Mr}$. Boody, of Brooks, Me., got by Gen. Knox, jr., dam, Messenger and thoroughbred. When five years old she was bought by S. H. Jacobs, Skowhegan, Me.

\section{BELLE KNOXALL.}

Bay filly, with star in forehead, and stripe on nose, foaled May 23, 1870, owned by Charles H. Morrill, Athens, Me., got by Lord's Knox, by Gen. Knox, dam, Jenny Lind, pedigree unknown.

\section{ECHO.}

Formerly called "Nell Seavey." Brown mare, with black points, and no white marks, $15_{\frac{1}{2}}^{\frac{1}{2}}$ hands high, foaled in June, 1864, bred by J. L. Seavey, of Waterville, Me., got by Gen. Knox, dam, the "Seavey mare" (the dam of Gen. Sherman and Violet), by Hiram Drew. Col. Seavey sold her to Abram Woodard, of Bangor, and he to J. F. Nodine, of Brooklyn, L. I., for $\$ 6000$.

At five years of age she trotted in $2.32 \frac{1}{2}$, in private. She was subsequently purchased by Mr. James B. Balch, of Brooklyn.

\section{BECKY SHARP.}

Dark brown mare, with white hind feet, $15 \frac{1}{2}$ hands high, foaled in 1867, bred by John Noyes, Fairfield, Me., got by Gilbreth Knox, dam, the John Noyes mare (so called), pedigree unknown, claimed to be an old Boston trotter. Becky Sharp trotted in 2.45, when four years old. She is now owned by parties in Boston.

\section{NELLIE BRIGGS.}

Bay mare, with star in forehead, and two white ankles 8* 
behind, $15 \frac{1}{4}$ hands high, foaled in June, 1867, bred by J. M. Littlefield, Abbott, Me., got by Jules Jergensen (then called Logan), dam, a chestnut mare, with white face and four white legs, of the Defiance stock.* Littlefield sold Nellie, when four months old, to Mr. Briggs, for $\$ 80$. Briggs kept her until 1872, and sold her to Mr. Walton, of New York, for Mr. Carman, the owner of Jules Jergensen, for $\$ 6,100$. Nellie trotted a full mile trial, on a hard, half mile track, July 3,1872 , in $2.30 \frac{1}{2}$.

\section{MORRIS COLT.}

Dark bay gelding, with star in forehead, spot on nose, and one white hind foot, foaled in 1868, bred by James Merrill, West Gardiner, Me., got by Whalebone Knox, dam, a Witherell mare.

This colt was sold, when three years old, to Lon Morris, of Boston. He is said to have shown a half mile in 1.17, and a quarter in 36 seconds, in the presence of Robert Bonner.

\section{BLACK JANE.}

Black filly, foaled in June, 1873, owned by John Ladd, North Livermore, Me., got by Ridley's Knox, dam, Rising Sun and Messenger.

\section{LADY KNOX.}

Dark brown mare, with black points and no white marks, $15 \frac{1}{2}$ hands high, foaled in 1865 , owned by Johnson \& Phair, Presque Isle, Me., got by Gen. Knox, dam, a Witherell mare. Lady Knox won a record of 2.47, in 1873, at Presque Isle.

* Defiance ras a pacing stallion, with white legs and blaze in face, brought from Canada. 


\section{SMUGGLER.}

Light roan colt, 16 hands high, and weighs 1050 pounds, foaled in 1868, owned by Johnson \& Phair, Presque Isle, Me., got by Tom Lang, dam, of Messenger descent.

\section{ONE EYE.}

Gray mare, $16 \frac{1}{4}$ hands high, and weighs 1225 pounds, foaled June 15, 1866, bred by W. Prescott, Dixmont, Me., got by Black Sultan, dam, by French Tiger. One Eye is now owned by Charles Shaw \& Son, Detroit, Me.

\section{LIVELY TIMES.}

Bay gelding, with black points, and star in forehead, 15 hands high, foaled in June, 1869, bred by the late J. H. Gilbreth, Fairfield, Me., got by Gilbreth Knox, dam, of Messenger descent. Lively Times owned by Charles Shaw \& Son, Detroit, Me.

\section{LITTLE ED.}

Spotted gelding, foaled in 1864; bred by Mr. Coolidge, of Solon, got by Gen. Knox, dam, a spotted mare, called an Arabian. Little Ed. was purchased, when eight years old, by Frank Heselton, Skowhegan, Me.

\section{RUBY.}

Dark bay mare, with black points, $15 \frac{1}{2}$ hands high, foaled in 1865, bred by Mr. Edwards, of Brooks, Me., got by Gen. Knox, dam, the dam of Gen. Knox, jr. Ruby was bought, when six years old, by Charles C. Emery, Skowhegan, Me. 


\section{PRIZE.}

Dark bay gelding, with black points, $15 \frac{1}{2}$ hands high, foaled in 1867, bred by Mr. Howes, of New Sharon, Me., got by Howe's Bismarck, dam, a Drew.

\section{NORTHERN SPY.}

Bay gelding, with black points, and star in the forehead, 16 hands high, foaled in 1867, bred by Mr. Nichols, of Vassalboro', got by Uncle Shube, formerly called Wier's Knox, dam, by Homan's Messenger. When five years of age, he became the property of Mr. Springer, proprietor of the Elm House, Skowhegan, Me.

\section{LADY KNOX.}

Black mare, with star in forehead, and one white hind foot, foaled in 1866, bred in Madison, Me., got by Gen. Knox, dam, a Drew mare. T. H. Springer, of Skowhegan, bought her when five years old, and took her to New York.

May 24, 1873, at the Fleetwood park, she won the last three out of four heats in a race in $2.38 \frac{1}{2}, 2.39 \frac{1}{2}, 2.40$, beating Lotta, who won the first heat, and Molly.

\section{AIR.}

Dark bay gelding, with black points, 15 hands high, foaled in 1868, owned by John Ayer, of Palermo, Me., got by Gen. Lightfoot, dam, not traced. At the Maine State Fair, of 1873, at Bangor, Sept. 17, he won the third and fourth heats in the 2.38 race in $2.38 \frac{1}{2}, 2.39 \frac{3}{4}$. 


\section{LADY MANSFIELD.}

Black mare, with no white marks, about $15 \frac{1}{2}$ hands high, foaled in 1868, bred by John Swain, of Wilton, Me., got by Howe's Bismarck. She was afterwards owned by Mr. Haines, of Livermore Falls, who sold her to Mr. Blaisdell, of Wilton. Blaisdell sold her to Eugene Allen, and he to Milton Holmes.

\section{RICKER KNOX.}

Bay mare, foaled in 186-, bred by Geo. W. Ricker, Augusta, Me., got by Gen. Knox, dam, by Hunton horse. Sold to Ira D. Sturgess, and by him to Gen. Wm. S. Tilton, Togus, Me.

\section{ROB ROY.}

Dark gray gelding, with star in forehead, and spot on nose, foaled May 26,1872, owned by John C. Pillsbury, Palmyra, Me., got by Pillsbury's Knox, dam, of Messenger descent.

\section{LADY MAUD.}

Black filly, foaled June 7, 1873, owned by John C. Pillsbury, Palmyra, Me., got by Pillsbury's Knox, dam, of Messenger descent.

\section{MUSIC.}

Black mare, foaled in 1870 , owned by C. A. Fuller, Fairfield, Me., got by the Townsend horse, by Gen. Knox, dam, unknown. 


\section{MINNEHAHA.}

Mahogany bay mare, with black points, and star in forehead, weight, 1050 pounds, foaled in 1869, bred by A. H. Rice, West Waterville, Me., got by Morrill's Knox, dam, Gipsey, a brown mare with white spots, got by an Arabian horse.

\section{CRAZY JANE.}

Bay filly, with black points, and star in the forehead, foaled in 1870, bred by A. H. Rice, West Waterville, Me., got by Morrill's Knox, dam, Gipsey.

\section{STARLIGHT.}

Dark brown filly, with spots, foaled May 23, 1871, bred by A. H. Rice, West Waterville, Me., got by Gen. Knox, dam, Gipsey.

\section{WILD NELLIE.}

Bay filly, with black points, and star in forehead, foaled May 4, 1872, bred by A. H. Rice, West Waterville, Me., got by Howe's Bismarck, dam, Gipsey.

\section{STAGNATION.}

Filly, foaled April 20, 1873, bred by A. H. Rice, West Waterville, Me., got bỷ Howe's Bismarck, dam, Gipsey.

\section{CAPITOLA.}

Black filly, with one white hind foot, and star in forehead, foaled June 15, 1872, bred by S. R. Bridgham, Hebron, Me., got by Gilbreth Knox, dam, the dam of Minot. 


\section{FLORA.}

Black filly, with star in forehead, foaled 1873 , bred by S. R. Bridgham, Hebron, Me., got by Howe's Bismarck, dam, the dam of Minot.

\section{SUNRISE.}

Dark brown filly, foaled in 1873 , owned by C. A. Fuller, Fairfield, Me., got by Knox Boy, by Gen. Knox, dam, known as the "Sherman Pishon mare," of Messenger descent.

\section{SABLE.}

Black stallion, foaled May 27, 1869, bred by Stephen Robinson, North Vassalboro', Me., got by Gen. Knox, dam, not traced.

\section{GARIBALDI.}

Dark gray stallion, with small white spot on upper lip, 15 hands, $2 \frac{1}{2}$ inches high, weighs 1000 pounds, foaled May 7, 1870, bred by John M. Cock, North Vassalboro", Me., got by Gen. Knox, dam, by Flying Mac, grand dam, a Witherell. Received one State premium.

\section{TOM HYER.}

Dark bay stallion, with black points, one white hind foot, foaled June 2, 1871, bred by John M. Cook, North Vassalboro', Me., got by Gen. Knox, dam, not traced.

\section{WHITE OAK.}

Gray gelding, foaled June 10, 1869, owned by O.W. Tilton, West Waterville, Me., got by Gen. Taylor, by Gen. Knox, dam, of Messenger descent. 


\section{LADY LEO.}

Dark bay filly, with black points, foaled June 3, 1871, bred by O. W. Tilton, West Waterville, Me., got by Leo, dam, an Indian Chief mare.

\section{SATURN.}

Blood bay stallion, with black mane and tail, stripe in face, and a little white on each hind foot, foaled April 23, 1871, bred by Fessenden Colcord, Fairfield, Me., got by Gen. Knox, dam, a mare of Messenger descent.

\section{THURLOW KNOX.}

Bay stallion, with black mane and tail, foaled in 1869 , and bred by A. G. Thurlow, South Poland, Me., got by Phil. Sheridan, dam, of Morgan descent.

\section{HIGHLAND BOY.}

Black stallion, with star in face, foaled in 1870, and bred by McIntyre \& Brickett, Smithfield, Me., got by Gen. Knox, dam, English, grand dam, Messenger.

\section{ZIG.}

Dark bay gelding, foaled in 1866, bred by H. G. Abbott, North Vassalboro', Me., got by Uncle Shube, formerly called Wier's Knox, dam, pedigree unknown.

\section{LOTTA.}

Chestnut mare, foaled 1868, bred by H. G. Abbott, North Vassalboro', Me., got by Gen. Knox, dam, by Homan's Messenger. 


\section{SNIP.}

Dark gray gelding, foaled 1868, bred by H. G. Abbott, North Vassalboro'; Me., got by Uncle Shube, dam, pedigree unknown.

\section{STAMP.}

Dark gray mare, foaled 1869, bred by H. G. Abbott, North Vassalboro', Me., got by Uncle Shube, dam, pedigree unknown.

\section{GEN. HOWE.}

Dark bay stallion, with black points, foaled June 2, 1870, bred by W. B. Hamlin, North Sidney, Me., got by American Boy, by Gen. Knox, dam, of Messenger descent.

\section{PLATO, Jr.}

Dark brown stallion, with black points, and white stripe in the face, foaled June 11, 1870, owned by George W. Bridges, Liberty, Me., got by Plato, dam, by Call horse, he by Imported Cannon Ball.

\section{ZENOBIA.}

Black filly, foaled in 1871, owned by George Taber, Vassalboro', Me., got by Gen. Knox, dam, pedigree unknown.

\section{SULTAN KNOX.}

Chestnut colt, foaled June 7, 1873, owned by Samuel Kennedy, Whitefield, Me., got by Black Sultan, dam, of Messenger descent. 


\section{DANDY JACK.}

Brown colt, with black points, foaled June 20, 1873, owned by Charles A. Frost, Corinna, Me., got by Bonny Doon, dam, by Skinner's Knox, grand dam, by Merrow horse.

\section{DANDY JIM.}

Stone gray colt, foaled June 19, 1873, owned by Lewis W. White, Corinna, Me., got by Bonny Doon, dam, of Messenger descent.

\section{CARELESS.}

Bay gelding, with stripe in face, and white hind feet, foaled June 20,1871, got by Count Monte Christo, dam, of Messenger descent.

\section{CORINNA MAID.}

Dark bay filly, with black points, foaled June 10, 1869, got by Skowhegan Boy, by Gen. Knox, dam, by Wildfire. Owned by Lewis W. White, Corinna, Me.

\section{LULA.}

Bay filly, foaled May 27, 1873, owned by R. A. Tibbetts, North Fairfield, Me., got by Quaker General, dam, Defiance.

\section{LITTLE BILL.}

Black colt, with star in forehead, foaled June 10, 1867, bred by A. S. Parker, Skowhegan, Me., got by Gen. Knox, dam, Kitty, by Witherell. 


\section{WHITE COLT.}

Brown colt, with black points, foaled May, 1872, bred by John M. White, Windham, Me., got by Major Knox, dam, Jeanette Rand.

\section{COUPON, JR.}

Brown colt, foaled in 1873, bred by S. P. Fox, Porter, Me., got by Coupon, dam, by Morrill Prince.

\section{HUNTER.}

Sorrel colt, foaled in 1871, owned by C. H. Skinner, St. Albans, Me., got by Skinner's Knox, by Gen. Knox, dam, an English mare.

\section{SOMERSET BOY.}

Roan colt, foaled in 1872 , owned by C. H. Skinner, St. Albans, Me., got by Emperor William, dam, by the Merrow horse.

\section{FERIDOON.}

Dark bay filly, with black points, and small star in forehead, foaled in June, 1871, owned by Charles A. Frost, Corinna, Me., got by Bonnydoon, dam, by Black Sultan.

\section{BLACK DINA.}

Black filly, with stripe in face, and one white hind foot, foaled in April, 1870, bred by Major John T. Richards, Gardiner, Me., got by Gen. Knox, dam, a thoroughbred mare, brought from Wilmington, N. C. Major Richards sold her, in 1873, to F. D. Harmon, Gardiner, Maine. 


\section{COLONEL ANDY.}

Black colt, foaled June 4, 1873, owned by Henry C. James, West Waterville, Me., got by Morrill Knox, dam, the Otis mare (so called), of Messenger descent.

\section{WILD ROSE.}

Bay filly, with black points, foaled May 16, 1872, owned by Henry C. James, West Waterville, Me., got by Morrill Knox, dam (the dam of Col. Andy), of Messenger descent.

\section{IADY STRATTON.}

Dark gray filly, with white stripe in face, foaled in June, 1871, owned by J. A. Sawtelle, West Waterville, Me., got by Honest John, dam, pedigree unknown.

\section{BLACK SWAN.}

Black filly, with star in forehead, and spot on nose, and two white hind feet, foaled May 11, 1871, bred by Robert Crockett, Rockland, Me., got by Gen. Berry, dam, a Drew.

\section{FRED. DOUGLASS (CROCKETT'S).}

Black colt, with star in forehead, foaled May 21, 1872, bred by Robert Crockett, Rockland, Me., got by Gen. Berry, dam, of Morgan descent.

\section{ROCKLAND MAID.}

Chestnut filly, with star in forehead, and spot on nose, and one white hind foot, foaled May 6, 1872, bred by Robert Crockett, Rockland, Me., got by Gen. Berry, dam, an imported English mare. 


\section{JOHN NEPTUNE.}

Bay colt, with star in forehead, and two white hind feet, foaled April 24, 1872, bred by Robert Crockett, Rockland, Me., got by Gen. Berry, dam, a Pennsylvania mare.

\section{JUNE BUG.}

Mahogany bay filly, with nigh hind foot white, foaled June 7, 1872, owned by D. D. Perkins, New Castle, Me., got by Othello, by Col. Ellsworth, by Gen. Knox.

\section{LADY DEMERRITT.}

Roan mare, with black points, 16 hands high, and weighs 1100 pounds, foaled in 1866, bred by Thomas DeMerritt, of Peru, Me., got by Gen. Knox, dam, by Old Eaton.

DeMerritt sold her, when five years old, to Childs Bros. and Foster, of Canton Point, Me.

\section{BELLE GILBRETH.}

Brown filly, with black points, foaled May 29, 1871, bred by D. M. Foster, Canton Point, Me., got by Gilbreth Knox, dam, by Goding's Brandy, afterwards called Jim Libby.

\section{LADY LEE.}

Black mare, foaled in 1868, owned by Merrill Lee, Riverside, Me, got by Gen. Knox, dam, a Kentucky thoroughbred.

KNOX MAID.

Black filly, foaled 1868, owned by Merrill Lee, River- 
side, Me., got by Gen. Knox, dam, the Knowell mare, the dam of Logan and Coupon.

\section{MERMAID.}

Roan filly, with black points, foaled May 26, 1871, bred by Allen Wade, Smithfield, Me., got by Hershom horse, by Gen. Knox, dam, a French Tiger mare.

\section{LADY LANG.}

Steel gray mare, with white stripe in face, foaled in 1867, owned by John D'Artherway, Augusta; Me., got by Gen. Knox, dam, a Tiger and Messenger mare, known as the Father Eagan mare. Lady Lang took the second premium, for two-year-olds, at the New England Fair, in 1869, under the name of Starlight.

\section{BELLE KNOX.}

Brown filly, with a few white hairs in forehead, foaled July 4, 1871, bred by J. G. Hanscom, Buxton, Me., got by Coupon, dam, Drew and Messenger.

\section{GENTLE NELLIE.}

Filly, foaled-, owned by Adelbert Kelley, Newburgh Centre, Me., got by Gen. Knox, dam, a Drew mare.

\section{CAPTAIN JIM.}

Brown colt, foaled in 1867, owned by J. H. Deering, Lisbon, Me., got by Sagadahoc, by Gen. Knox, dam a trotting mare, pedigree unknown.

ROSA INNOX.

Dark bay filly, with star in forehead, and two white 
feet, foaled May 24, 1872, owned by J. H. Deering, Lisbon, Me., got by Sagadahoc, dam, Jenny Lind, by Old Drew.

\section{BELLE BARBOUR.}

Black filly, foaled June 25, 1870, owned by Edwin 'I'homas, Newburgh, Me., got by Young Sultan, by Black Sultan, dam, Morgan Fox.

\section{BROWN BESS.}

Brown mare, with star in forehead, and white spot on nose, foaled August 5, 1868, owned by D. C. Lyford, Corinna, Me., got by Knox, jr., dam, by Lang's Telegraph.

\section{JENNY.}

Bay mare, with black points, $15 \frac{1}{4}$ hands high, foaled in 1868, bred by Charles Richards, Wilton, Me., got by Howe's Bismarck, dam, by Sandy River horse. Sold, when three years old, to M. A. Allen, East Buckfield, Me.

\section{BEDROCK.}

Chestnut colt, with star in forehead, and stripe on nose, foaled May 13, 1873, bred by H. N. Leighton, Augusta, Me., got by Col. Kling, dam, Lady Balrownie, by Balrownie, out of the Dane mare, a celebrated trotter, formerly owned by Robert Sears, of Boston.

\section{JENNY WREN.}

Sorrel filly, with white stripe in the face, foaled April, 1871, bred by John M. White, Windham, Me., got by Major Knox, dam, Jeanette Rand, by Harris' Hambletonian. 


\section{DOTTY DIMPLE.}

Gray filly, with one white hind foot, and blaze in face, foaled August 7, 1871, bred by F. J. \& G. W. Lawrence, Fairfield, Me., got by Gen. Knox, dam (the dam of Butterball), by Homan's Messenger.

\section{SPRUCE.}

Bay filly, foaled July 2, 1871, bred by E. J.\& G. W. Lawrence, Fairfield, Me., got by Gen. Knox, dam, a dark bay mare, said to be by an English horse, brought from New Brunswick.

\section{TOPSY.}

Brown mare, foaled June 28, 1869, owned by Andrew Keay, Winslow, Me., got by Ivanhoe, by Gen. Knox, dam, the dam of Lady Annfield.

\section{PRINCESS LOUISE.}

Black filly, foaled in 1872, owned by C. H. Skinner, St. Albans, Me., got by Gen. Knox, dam, a fast trotting mare of Messenger descent.

\section{BLACK EYED SUSAN.}

Bay filly, foaled in 1872, owned by C. H. Skinner, St Albans, Me., got by Skinner's Knox, by Gen. Knox, dam, pedigree unknown.

\section{VICTORIA PARSONS.}

Bay filly, foaled in 1S72, owned by C. H. Skinner, St. Albans, Me., got by Emperor William, dam, a Crawford mare. 
FAIRY BELL.

Gray filly, foaled in 1870 , owned by C. H. Skinner, St. Albans, Me., got by Skinner's Knox, by Gen. Knox, dam, of Messenger descent.

\section{LADY DANFORTH.}

Sorrel filly, with light mane and tail, and stripe in face, foaled June, 1871, owned by Stephen S. Delano, North Fairfield, Me., got by the Tozier horse, by Black Stranger, dam, of Messenger descent.

\section{BESSIE KNOX.}

Black filly, foaled July 24, 1871, bred by William Gray, Windsor, Me., got by Gen. Knox, dam, by Crummett horse. Purchased by Gen. W. S. Tilton, Togus, Me.

\section{BEAU HICKMAN.}

Dark steel gray stallion, 15 hands high, owned by E. T. Wells, Mercer, Me., got by the Hallett horse, by Gen. Knox, dam, by Roman Eaton, grand dam, by Old Witherell, great grand-dam, by Duroc.

\section{SULTAN JUNIOR.}

Black stallion, 15 hands, $2 \frac{1}{2}$ inches high, and weighs 1100 pounds, owned by C. Butman, Plymouth, Me., foaled in 1867, got by Black Sultan, dam, by Don Juan, by Old Drew, 2d dam, by Morgan Fox.

\section{BONNEY'S KNOX.}

Mahogany bay stallion, 16 hands high, foaled in June, 1871, bred by I. E. Bonney, Winthrop, Me., got by Gen. 
Knox, dam, by Black Lion, 2d dam, by Old Witherell, 3d dam, by the Avery horse.

\section{BENDIGO.}

Dark bay stallion, with black points, and star in forehead, foaled May 26, 1873, owned by H. C. Orr, Freeport, Me., got by St. Elmo, by Gen. Knox, dam, Lady Washington, of Messenger descent.

\section{MABEL.}

Bay filly, foaled May 1, 1873, bred by James Towle, Limerick, Me., got by Coupon, dam, by Holland's Ethan Allen.

\section{MAQUD MULLER.}

Gray filly, foaled in May, 1873, bred by John H. Foss, East Parsonsfield, Me., got by Coupon, dam, gray mare, Nellie, of Messenger descent.

\section{CLARA BELL.}

Mare, foaled June 26, 1869, owned by G. A. Bragg, Nortl Carmel, Me., got by Black Sultan, dam, a Hambletonian mare.

\section{LADY KILDARE.}

Black filly, foaled May 18, 1870, bred by Granville Hackett, West New Portland, Me., got by Larkin's Gen. Knox, Jr., dam, by Sandy River horse.

\section{MAUD RICHMOND.}

Bay filly, with black points, star in forehead, and twa white ankles behind, foaled June 9, 1872, bred by C. C. 
Richmond, East Monmouth, Me., got by Whalebone Knox, dam, thoroughbred. Richmond sold her, in 1873, to a gentleman in Bethel, Me.

\section{MAYFLOWER.}

Dark brown filly, with stripe in forehead, foaled May 1, 1872, bred by Henry M. Lander, Fairfield Centre, Me., got by Drummond Knox; dam, Kitty Wells, by a thoroughbred.

\section{FANNY GRANGER.}

Black filly, with star in forehead, and stripe over left nostril, foaled July 1, 1871, owned by Luke Hilton, Skowhegan, Me., got by Gen. Knox, dam, a bay mare, got by an English horse, pedigree, unknown.

\section{LADY LITTLEFIELD.}

Bay filly, foaled April 25, 1870, bred by Geo. F. Moore, North Anson, Me., got by Logan (now called Jules Jergensen), dam, the Fitzgerald mare, by the Proctor horse.

\section{LADY SPEEDWELL.}

Brown filly, foaled June 12, 1873, bred by A. G. Thurlow, South Poland, Me., got by Phil. Sheridan, dam by Hampton.

\section{MAGGIE MAY.}

Black filly, foaled in June, 1871, bred by Walter R. Cur-。 tis, North Dixmont, Me., got by Thomas' Knox, by Black Sultan, dam, Black Hawk. 


\section{NELLIF KLING.}

Sorrel mare, foaled in 1869 , owned by W. G. Rand, New Sharon, Me., got by Col. Kling, dam, a Witherell mare.

\section{BELL MUNSON.}

Filly, foaled April 27, 1871, bred by A. G. Thurlow, South Poland, Me., got by Phil. Sheridan, dam, a Morgan mare.

\section{NELLY KNOX.}

Black mare, foaled in 1865, owned by B. R. Hunt, Unity, Me., got by Gen. Knox, dam, pedigree unknown.

\section{BIRDCATCHER.}

Dark bay mare, with black points, foaled May 22, 1870, bred by B. R. Hunt, Unity, Me., got by Gilbreth Knox, dam, of Morgan and Messenger descent.

\section{WHITE STOCKINGS.}

Black filly, with three white feet, foaled May, 1872, bred by B. R. Hunt, Unity, Me., got by Gilbreth Knox, Jr., dam, of Morgan and Messenger descent.

\section{PRUDY.}

Gray filly, foaled March 26, 1872, bred by D. A. Coney, Augusta, Me., got by Col. Kling, dam, the Messenger mare, Bess.

\section{JOHNNY O'BRIEN.}

Sorrel colt, with white stripe in face, foaled May 10, 1872, owned by J. H. Downs, Mercer, Me., got by Gen. 
Howard, by Gen. Knox, dam, by Holbrook horse, by Allen's Black Hawk.

\section{TOM MOORE.}

Bay colt, foaled June 17, 1871, bred by Geo. F. Moore, North Anson, Me., got by Gilbreth Knox, dam, the Fitzgerald mare, by the Proctor horse.

\section{HUMMINGBIRD.}

Dark sorrel colt, foaled in 1870, owned by Gustavus Sawtelle, Sidney, Me., got by Col. Kling, dam, an Eaton mare.

\section{KING BIRD.}

Gray gelding, foaled May, 1870, owned by H. A. Archer, Fairfield, Me., got by Honest John, dam, Shoo Fly, by Rising Sun.

\section{LOOKOUT.}

Bay colt, with nigh hind foot white, and star in the forehead, foaled May 26, 1873, bred by H. A. Archer, Fairfield Centre, Me., got by Gen. Lightfoot, dam, Shoo Fly, by Rising Sun.

\section{BLACK DONALD.}

Black colt, foaled May 1, 1873, bred by Albert H. Lord, Hallowell, Me., got by Col. Kling, dam, Lady Catherine.

\section{DICK.}

Dark chestnut stallion, with star in forehead, spot on nose, and one white hind foot, foaled in August, 1869, 
bred by D. C. Tozier, Waldo, Me., got by Gen. Knox, dam, an English mare.

\section{SCIENTELLA.}

Bay filly, with star and snip, and one white ankle, foaled Sept. 27, 1872, bred by Gen. W. S. Tilton, Togus, Me., got by Drummond Knox, dam, by Seeley's American Star. Sold, in 187:3, to George H. Bailey, Woodford's Corner, Me.

\section{KITTY KNOX.}

Bay filly, with star in forehead, and two white hind ankles, foaled May, 1871, bred by Elihu Lawrence, Fairfield, Me., got by Gen. Knox, dam, Juno, by Norman, he by Truedell, a thoroughbred.

\section{JUNO, 2D.}

Sorrel filly, foaled in May, 1872, bred by Elihu Lawrence, Fairfield, Me., got by Drummond Knox, dam, Juno, by Norman.

\section{LADY ELLSWORTH.}

Roan mare, with black points, white star in forehead, and white hind feet, foaled July 26, 1868, bred by L. R. Powers, Georgetown, Me., got by Col. Ellsworth, by Gen. Knox, dam, a Messenger mare.

\section{NELLIE CLIPPER.}

Iron gray mare, 16 hands high, and weighs 1200 pounds, foaled May 19, 1868, owned by S. R. Fuller, Eustis, Me., got by Gen. Knox, dam, pedigree unknown. 


\section{DOLLY GRAY.}

Roan filly, foaled April 20, 1873, bred by A. G. Thurlow, South Poland, Me., got by Phil. Sheridan, dam, of Morgan descent.

\section{LIZZIE KEELER.}

Brown filly, foaled May 29, 1872, bred by Henry K. Sawyer, South Norridgewock, Me., got by Howe's Bismarck, dam, Brown Betsey.

\section{LUCY KNOX.}

Brown mare, foaled June 30, 1866, owned by J. B. Watts, Thomaston, Me., got by Gen. Knox, dam, Fanny, by Hill's Racker. 


\section{BLACK HAWK STOCK.}

\section{BROWN HARRY.}

Dark brown stallion, with one white ankle behind, and white crescent in the forehead, with heavy, wavy black

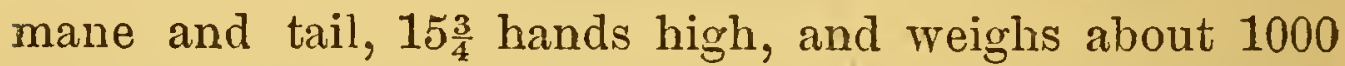
pounds, foaled June 17, 1856, the property of P. M. Jefferds, of Foxcroft, Me, got by Thurston Black Hawk, he by Vermont Black Hawk, by Sherman, by Justin Morgan, dam, a sorrel pacing mare, about 15 hands high, and weighed 960 pounds, bought in Lowell, Mass., of $\mathrm{H}$. Woodward, by Mr. Jefferds. Her pedigree was never satisfactorily established. She was at that time about twenty years old, and was in foal. The produce was Brown Harry. Mr. Jefferds sold him, when two years old, to Mr. H. Woodward, of Lowell, Mass., the gentleman from whom he purchased his dam. He sold him, when four years old, to Mr. R. F. Yeatton. In $1862 \mathrm{Mr}$. Yeatton went into the army, and he came again into Mr. Jefferds? hands, and stood at Foxcroft two years. In 1864 he was sold to Mr. S. D. Cushman, of Dexter, Me., his present owner. He is a very elegant horse, and has sired some fine colts. He has a very nervous temperament, with a slight dash of temper. His stock resemble him, are stylish, with good action, and many of them fast. It is . said that he has trotted a mile in 2.36, and a half in 1.16, without preparation. 


\section{PRINCE HARRY.}

Black stallion, with no white marks, $15 \frac{1}{4}$ hands high, and weighed about 900 pounds, foaled in June, 1864, bred by P. M. Jefferds, Foxcroft, Me., got by Brown Harry, dam (the dam of Penobscot Chief), said to be by Royal George. Mr. Jefferds took him to Portland, to the State Fair, in 1868, where he beat a field of nine colts, and took the first premium for four-year-old stallions. In 1869, Mr. Jefferds sold him to O. M. Shaw, of Bangor, for $\$ 2,500$. Mr. Shaw had him gelded, and sold him to N. H. Leadbetter, of New York City.

\section{BLACK HAWK CHIEF.}

Dark bay stallion, with small star, foaled June 23, 1871, bred by George Hamilton, Dexter, Me., got by Brown Harry, dam, a highly bred Black Hawk mare. Mr. Hamilton sold him, in 1873, to Messrs. Parlin \& Hoyt, Phillips, Me.

\section{BAY HARRY.}

Bright bay stallion, weighs about 1100 pounds, foaled in 1865, bred by J. B. Chase, Dover, Me., got by Brown Harry, dam, of Messenger descent. Afterwards owned by H. G. Coburn, Lincoln, Me., and finally by Timotby Fuller, also of Lincoln.

\section{NAPOLEON.}

Brown stallion, foaled in 1870 , bred by C. A. Cushman, of Lee, Me., got by Bay Harry, dam, pedigree unknown.

\section{FLYING HARRY.}

Dark iron gray stallion, foaled in 1867, owned by Geo. 9* 
S. Worcester, Mt. Vernon, Me., got by Brown Harry, dam, by French Tiger.

\section{BLACK DUTCHMAN.}

Black stallion, with small blaze in face, and one white hind foot, and weighs 1000 pounds, foaled in 1864, bred by Wm. H. Caldwell, of Rumford, Me., got by Flying Black Hawk, of Vermont, dam, of Morgan descent. Owned by Ervin Robinson, East Sumner, Me.

\section{JIM CROW.}

Black stallion, $15 \frac{1}{2}$ hands high, and weighs 1100 pounds, foaled in 1865, bred by Nahum W. Mason, of Grafton, Me., got by the Ramsey Black Hawk, of Vermont, he by Thurston Black Hawk, dam, by Rising Sun. Owned by Thomas B. Kendall, Bethel, Me.

\section{YOUNG TELEGRAPH.}

Black stallion, $15 \frac{1}{2}$ hands high, and weighs 1050 pounds, foaled in 1867, bred by F. N. Joaquin, Athens, Me., got by Ben Butler, he by Black Hawk Telegraph, known in Maine as "Lang's Telegraph." The pedigree of Black Hawk Telegraph is as follows: Got by Vermont Black Hawk, dam, by Sir Walter (2320, Wallace), grand dam, by Burge horse, son of Sir Charles, 2285. Black Hawk Telegraph was burned at the Riverside Park, Boston, in 1864. The dam of Young Telegraph is supposed to be of Messenger descent.

GEN. GRANT (CHASE's).

Black stallion, 15 hands high, and weighs 950 pounds, foaled in 1869, bred by Josiah Wedgewood, and owned 
by David M. Chase, North Parsonsfield, Me., got by Young Black Hawk, by Black Hawk, Jr., he by Vermont Black Hawk, dam, by the Samuel Ames horse, pedigree unknown.

\section{VIRGINIA BOY.}

Dark dapple gray stallion, weighs about 975 pounds, foaled in 1868, bred by a Mr. Parsons, of Farmington, Me., got by a Black Hawk called Black Stranger, of Augusta, Me., dam, a mare from Virginia. Owned by M. M. Damon, Lakeville Plantation, Penobscot Co., Me.

\section{FLEETWOOD (SMITH'S).}

Chestnut stallion, with black points, 15 hands high, and weighs 950 pounds, foaled June 24, 1869, bred by O. C Smith, Richmond, Me., got by Young Black Hawk, he by Chieftain, and he by the original Black Hawk.

\section{EASTERN BOY (HUSSEY'S.)}

Black stallion, 15 hands high, and weighs 1080 pounds, foaled in 1868, bred by S. H. Hussey, Houlton, Me., got by Black Hawk Plato, dam, a black trotting mare, called Nellie.

\section{ANDREW JOHNSON.}

Black stallion, with white hairs mixed in flanks, stripe in face, diamond on nose, and off hind foot white, $15_{\frac{1}{2}}$ hands high, and weighs 1000 pounds, foaled May 25, 1868, bred by Silas C. Churchill, North Raymond, Me., got by Young Black Hawk, he by Chieftain, or Rix horse, he by the original Black Hawk, dam, of Andrew Johnson, was a Messenger. 


\section{COL. TALBOT.}

Glossy black stallion, with brown muzzle and flanks, 15 hands high, and weighs about 1000 pounds, foaled June. 20, 1856, bred by W. A. Vose, Robbinston, Washington county, Me., got by Champion Black Hawk, dam, a mare from New Brunswick. Owned by J. D. Tucker, Lincolnville, Me.

\section{RUBICON.}

Sorrel colt, with white stripe in face, and white hind foot, weighs 1100 pounds, foaled in 1869, bred by John M. White, Windham, Me., got by Sherman Black Iawk, dam, Jeanette Rand, by Harris'. Hambletonian.

\section{NORTH STAR.}

Chestnut colt, with star in forehead, and little white on nigh hind foot, foaled May 7, 1873, bred by Geo. Hamilton, Lake Side Farm, Dexter, Me., got by Sherman Knox, dam, the thoroughbred mare, "Starlight," imported, in 1867, from England, by Col. Jennings, commanding Troop F, 13th Hussars, Montreal, C. E., got by "The Baron," 2d dam, by Touchstone, by Camel, by Whalebone, by Waxy, etc. The Baron was an English racer, winner of the St. Ledger, in 1845.

\section{BLACK HARRY.}

Black stallion, with star in the forehead, $15 \frac{1}{2}$ hands high, foaled May 5, 1870, bred by Ira C. Harmon, Lee, Me., got by the Humphrey horse, by Sherman Black Hawk, dam, by Col. Crockett. 


\section{DEXTER BOY.}

Bay stallion, with black points, foaled May 24, 1869, bred by C. F. Carlton, Dexter, Me., got by Gen. Sherman, by Black Hawk, dam, by the Tewksbury horse, by French Tiger.

\section{LITTLE MAC.}

Black roan stallion, $14 \frac{3}{4}$ hands high, foaled in 1868 , bred by S. Ramsdell, Prentiss, Me., got by a Black Hawk horse, dam, of Messenger descent. Owned by S. B. Gates, Springfield, Me.

\section{ST. ELMO.}

Gray gelding, $15 \frac{3}{4}$ hands high, foaled in 186-, bred by S. R. Jackson, of Foxcroft, Me., got by Brown Harry, dam, by French Tiger. He was afterwards owned by S. G. Rowe, of Dexter, and finally by Rockwell \& Bacon, New London, Conn. June 21, 1872, at the Mystic Park, Boston, he won the first heat in a race, and a record of $2.29 \frac{1}{2}$, but was second in the race.

\section{LADY HAMILTON.}

Dark bay mare, about $15 \frac{1}{2}$ hands high, foaled in 186-, bred by Jacob Hamilton, Sebec, Me., got by Brown Harry, dam, of Messenger descent. Taken to Massachusetts, where she is said to have a record of 2.37 .

\section{MADAME PAREPA.}

Gray mare, $15_{\frac{1}{2}}$ hands high, foaled in 1868, owned by George Hamilton, Dexter, Me., got by Brown Harry, dam, of Messenger descent. 


\section{NETTIE.}

Roan mare, with black points, foaled in 1867 , bred by John Andrews, Exeter, Me., got by Brown Harry, dam, of Messenger descent. Owned by Samuel T. Luce, Levant, Me.

\section{GEN. JACKSON.}

Dapple brown stallion, with small blaze in face, $15 \frac{1}{2}$ hands high, and weighs 1000 pounds, foaled May 14, 1868, bred by Ira C. Harmon, Lee, Me., got by the Humphrey horse, he by Sherman Black Hawk, dam, Nellie, by Col. Crockett, he by Old Col. Crockett. July 4, 1873, at the Lee Trotting Park, in a race with Paddy, he won in straight heats, the fastest being 2.53. Afterwards a match was made between them and trotted at Bangor, in which Gen. Jackson was beaten, being in an unfit condition. Mr. Harmon sold him, in the fall of 1873, to Fred. Jordan, of Oldtown.

\section{KATE GILBERT.}

Brown mare, about 15 hands high, foaled in 1865, bred by Ezekiel Bosworth, Hartford, Me., got by Champion Black Hawk, he by Rix Black Hawk, and he by the original Vermont Black Hawk. The dam of Kate Gilbert was a medium size bay mare, got by a son of Trustee Messenger, and out of a mare by Rising Sun. Bosworth sold her, when three years old, to his brother, at Bryant's Pond, Me., he to R. A. Gowell, of Canton, and he to Farrar \& Morrill, of Buckfield, and they took her to Massachusetts. In 1872, in a race, she obtained a record of 2.38 $\frac{1}{2}$. At Concord, N. H., Sept. 24, 1873, she won a race, beating Dictator, Green Mountain Maid, Flora and Silvia 


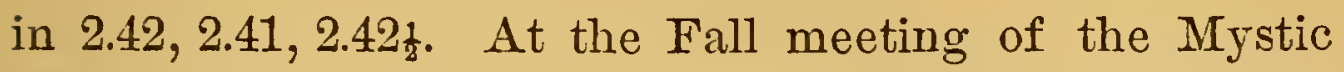
Park, Oct. 15 and 16, Kate Gilbert won the 2.37 race, winning the second heat in 2.35 , the sixth in 2.37 , and the seventh heat and race in 2.39, beating Brom Keeney, Deacon, Modoc, Pearl, Green Mountain Maid and Flora.

\section{ANSON BELLE.}

Black mare, 15 hands high, foaled in 1867 , bred by $\mathrm{S}$. S. Gould, North Anson, Me., got by Sawyer Black Hawk, he by Allen Black Hawk, and he by Sherman Black Hawk, dam of Anson Belle, by Witherell.

\section{VICTORIA.}

Black mare, $15 \frac{3}{4}$. high, foaled in 1866 , owned by N. C. Trim, Charleston, Me., got by Ben. Butler, by Roughand-Ready, by Hills' Black Hawk, dam, by Young Gleaner, who was English and Arabian.

\section{BLACK PRINCE.}

Black gelding, with star in forehead, and stripe on nose, $15 \frac{1}{4}$ hands high, foaled in July, 1866, bred by Sylvanus Porter, North Yarmouth, Me., got by Sherman Knox, dam (the dam of Andy Patchen), by the Chadbourne horse, he by Old Morgan Celon.

Black Prince was purchased by V. C. Hall, of Windham, Me., and he won a race at Waterville, in July, 1873, trotting a half mile in $1.18 \frac{1}{2}$, and a fifth heat in 2.50.

\section{SPEEDAWAY.}

Bay mare, with black points, foaled in 1866 , owned by Luther Kimball, Bridgton, Me., got by Paul Cook, by Paul Clifford, dam, by Old Celon. 


\section{CAPTAIN JACK.}

Black colt, with star in forehead, bred by A. Cushman, Jr., Sher'man, Me., got by Young Champion Chieftain, by Old Chieftain, by Vermont Black Hawk, dam, a fast trotting mare, of Morgan descent.

\section{CAPITOLA.}

Black mare, foaled June, 1869, owned by S. P. Archibald, Monticello, Me., got by Black Hawk Plato, by Sherman Black Hawk, dam, of Nigger blood.

\section{FEARFUL.}

Chestnut colt, with white in face, foaled May 25, 1873, bred by M. A. Allen, East Buckfield, Me., got by Champion Black Hawk (the sire of Kate Gilbert), dam, Jenny, by Howe's Bismarck.

\section{PASSAMAQUODDY GIRL.}

Black mare, foaled June 10, 1870, owned by M. A. Jackson, Eastport, Me., got by Black Hawk, by Trotting Childers, dam, a Morgan mare, from Vermont.

\section{ROSALIE.}

Roan filly, foaled June, 1870, owned by J. C. Small, Portland, Me., got by. Sherman Knox, dam, thoroughbred.

\section{ANDROSCOGGIN BOY.}

Gray gelding, $15 \frac{3}{4}$ hands high, foaled in 1865 , bred by J. M. Brown, of Hanover, Me., got by a Black Hawk horse, brought from New Hampshire, dam, by Trustee Messenger. 
Mr. Brown sold him to Charles Kimball, of Rumford, when two years old.

\section{ZERO.}

Gray gelding, 15 hands high, owned by Waldo $\mathrm{T}$. Pierce, of Bangor, Me., got by Brown Harry, dam by French Tiger, being full brother to St. Elmo. He has no record, never having started in a race, but is said to have trotted one-half mile, in private, in 1.12. 


\section{MORRILL STOCK.}

\section{WINTEROP MORRILL.}

Formerly called Slasher. Bay stallion, with full black mane and tail, star in forehead, and one white hind foot, $15 \frac{1}{2}$ hands high, and weighs about 1050 pounds, foaled in 1855 , bred by Mr. Bradford, Barre, Vermont, got by Perkins' Young Morrill, dam, by the Huckins horse, by Royal Morgan, he by Sherman, by Justin Morgan. Sold, when about three years old, to Mr. Town, who was, we believe, a former owner of Young Morrill, and afterwards to $\mathrm{Mr}$. Varill, Laconia, N. H., and $\mathrm{D}$. H. Blanchard, Boston. In 1862 he was brought to Maine, by Asher Savage, of Waterville, and was at that time a pacer. After being sold several times for about $\$ 100$, he was brought to Winthrop, in January, 1863, and in the following August he was purchased by Jackson \& Rounds.

In Winthrop he was first called Winthrop Boy, and finally Winthrop Morrill. At Mr. Chas. G. Jackson's death, his interest passed into his son's hands, and he remained with J. F. Jackson, until the fall of 1871, when he was sold to T. B. Williams, of Boston, it is said for $\$ 8,250$. As a sire of trotters he ranks with the best that ever stood in Maine. He is the sire of Glengary, Fleetwood, Baby Boy, Ben Morrill, Sam Curtis, Modoc, Sweet Briar, and many other fast ones. 


\section{WINTHROP MORRILL, JR.}

Black stallion, with no white marks, $15 \frac{1}{2}$ hands high, and weighs about 1000 pounds, foaled in 1854, bred by Nathaniel Gould, of Camden, Me., got by a horse called Metacomet, he by the Old Morrill horse, of Danville, Vt. Metacomet has since been gelded, and sold to go to New York. The dam of Winthrop Morrill, Jr., was a small mare, of the Fox breed. He was first called Butcher Boy, and Oct. 15, 1868, as a four-year-old, he trotted over the Belfast Trotting Park, and obtained a record of 2.55 .

He was afterward sold to John Morgan, of Pembroke, Me., and by him to G. H. Cotton, of Somerville, Mass.

June 3, 1873, at Beacon Park, Boston, in a race for horses that had never beaten 3.00 , he won the fourth heat, and a record of $2.34 \frac{1}{2}$.

June 5, two days afterward, at the same place, he won the 2.50 race, beating six horses. The race was one of four heats, the last three of which he won, time, $2.33 \frac{3}{4}$, $2.34 \frac{3}{4}, 2.32 \frac{3}{4}$.

June 18, at Fleetwood Park, New York, he won the 2.50 race, beating ten horses, winning the first, third and fourth heats, in $2.33,2.31,2.35$.

June 26, at the same place, he won the first, fourth and fifth heats, in the 2.43 race in $2.31 \frac{3}{4}, 2.31 \frac{1}{4}, 2.34 \frac{1}{2}$.

August 20, at Hampden Park, Springfield, Mass., he won a race for horses that never beat 2.31. The race in which ten heats were disposed of, was a very severe one, Winthrop Morrill, Jr., winning the sixth, eighth and tenth heats and race in $2.35 \frac{1}{2}, 2.34,2.37$.

Sept. 25, at the Prospect Park Fair Grounds, he won a race in three straight heats, in $2.30,2.32,2.28 \frac{3}{4}$, beating 
Lady Emma, Rose Standish, Sir Knight and Rowe's Tommy.

\section{BEN. MORRILL.}

Brown stallion, $15 \frac{1}{4}$ hands high, foaled in 1868 , bred by Harrison Ames, Winthrop, Me., got by Winthrop Morrill, dam, by Old Columbus. Ames sold him to W. B. Bonney, of Winthrop, and he sold him when two years old to J. F. Jackson, also of Winthrop. Jackson sold him to J. G. Rounds, of Lynn, Mass., and he to T. B. Williams, of Boston. At Prospect Park, Long Island, Oct. 21, 1872, in a race for four-year-old colts, best three in five, in harness, for a purse of $\$ 1,600$, there were the following entries: Ben. Morrill, by Winthrop Morrill, Rowe's Tommy, by Thomas Jefferson, Dixon, by Happy Medium, and Silver Heel, by Rysdyk's Hambletonian.

The first heat was won by Rowe's Tommy, in $2.48 \frac{1}{4}$, Ben Morrill, second, and Dixon distanced. Silver Heel having been drawn, only two were left to contend for the prize. The second heat was won by Ben. Morrill, in 2.34 the third in $2.32 \frac{3}{4}$, and the fourth in 2.36 .

The value of this performance should not be under estimated. Not only was the time remarkable, considering the age of the contestants, the third heat being in $2.32 \frac{3}{4}$, and the first half in $1.13 \frac{3}{4}$, but it should be borne in mind that the colt had to contend against the representatives of the best blood in the country. Rowe's Tommy, being by Thomas Jefferson, one of the most promising young horses in the country, he by Toronto Chief, out of the famous Gipsey Queen. Dixon is also a . scion of a noble race, his sire being Happy Medium, by Rysdyk's Hambletonian. Happy Medium's dam was no 
less a mare than the renowned Princess, so famous for her many contests with Flora Temple.

\section{BLINN MORRILL.}

Black stallion, with star in forehead, and one white hind foot, foaled May 21, 1870, bred by Joshua Blinn, Dresden Mills, Me., got by Winthrop Morrill, dam, Nellie, half sister to Dresden, grand-dam, by Young Indian Chief.

\section{VULCAN.}

Bay stallion, with black points, $15 \frac{1}{4}$ hands high, and weighs about 950 pounds, foaled June 10, 1870, bred by John F. Whidden, Augusta, Me., got by Winthrop Morrill, dam, an English and French mare, called the Sam Jacobs mare.

\section{WINTHROP.}

Bāy stallion, with white face and three white feet, $15 \frac{3}{4}$ hands high, foaled in 1869, bred by G. H. Fulsom, of Winthrop, Me., got by Winthrop Morrill, dam (the dam of Sam Curtis), by Old Eaton. Fulsom sold him, when o ne year old, to B. S. Wright, of Boston.

\section{KNOX MORRILL.}

Black stallion, with star and one white hind foot, $15 \frac{1}{4}$ hands high, and weighs about 950 pounds, foaled in 1869 , bred by Peter Letourneau, of West Waterville, Me., got by Winthrop Morrill, dam, a bay mare, by Gen. Knox. He was subsequently purchased by J. F. Jackson, Winthrop, Me. 


\section{YOUNG WINTHROP MORRILL.}

Bay stallion, with black points, $15_{\frac{1}{2}}^{\frac{1}{2}}$ hands high, and weighs 1000 pounds, foaled in 1865, bred by J. O. Wing, of Winthrop, Me., got by Winthrop Morrill, dam, by Lang's Telegraph.

\section{JOE MORRILL.}

Brown stallion, with white star, and one white ankle, foaled in 1871, bred by Joseph Wood, of Winthrop, Me., got by Winthrop Morrill, dam, pedigree unknown. Wood sold him, when four months old, to J.F. Jackson, of Winthrop, and he, when a yearling, to T. B. Williams, of Boston.

\section{MORRILL PRINCE.}

Black stallion, with white spot on hind foot, $15 \frac{3}{4}$ hands high, and weighs 1000 pounds, foaled in 1868, bred by W. Hanson, of Winthrop, Me., got by Morrill Champion, a black stallion, bred in Vermont, got by the Old Morrill horse, and brought to Maine by Mr. William Beal, of Winthrop, and owned by him until he died, in 1870, of rupture. Shortly before his death Mr. Beal was offered $\$ 2000$ for him. The dam of Morrill Prince was by Old Witherell. Hanson sold him, when five months old, to Mr. William Beals.

\section{MONARCH.}

Black stallion, with one white hind foot, foaled in 1869 , bred by Reuben Jones, of Winthrop, Me., got by Morrill Champion, dam, a gray mare, by Tam O'Shanter. Jones sold him to Mr. John Packard, also of Winthrop. 


\section{WINTHROP MORRILL, JR. (Titus').}

Sorrel chestnut stallion, $15 \frac{1}{4}$ hands high, and weighs 950 pounds, foaled in 1867, bred by H. R. Titus, Monmouth, Me., got by Winthrop Morrill, dam, by Witherell, grand dam, by the Hanscomb horse, he by the Young Quimby horse, he by the Quimby horse.

\section{PHILLIP MORRELL.}

Dark brown stallion, weighing 1000 pounds, foaled in 1865, owned by James M. Ayer, Cornish, Me., got by Johnny Morrill (Morrill Prince), dam, by Sir Charles.

\section{JACK OF HEARTS.}

Dark chestnut stallion, with black mane and tail, 16 hands high, foaled 1869, bred by Andrew Dunton, of Liberty, Me., got by Gen. Howard, he by the Morrill horse, Metacomet, dam, a French blood mare. Owned by Cyrus W. Maddocks, Appleton, Me., R. D.

\section{YOUNG MORRILL, JR.}

Black stallion, $15 \frac{1}{2}$ hands high, and weighs 960 pounds, foaled in 1863, bred by D. F. Harlow, Phillips, Me., got by the Blanchard horse, of Phillips, he by Perkins' Young Morrill, of Massachusetts, dam, an Eaton and Witherell mare. Orned by T. N. Washburn, Peru, Me.

\section{BILLY MORGAN.}

Bay stallion, with star in forehead, foaled in 1871 , bred by Daniel W. Foye, Upton, Me., got by Green Miountain Morrill, dam, of Morgan descent. 


\section{HIRAM MORRILL.}

Chestnut stallion, 15 hands high, foaled May 11, 1869, bred by Heber Kimball, of Bridgton, Me., got by Winthrop Morrill, dam, part Drew.

\section{YOUNG MORRILL.}

Dark chestnut stallion, foaled May 14, 1870, owned by Edward Leonard, Whitefield, Me., got by Flying Morrill, dam, by Hector.

\section{RECKLESS.}

Brown black stallion, $15 \frac{1}{2}$ hands high, foaled May 22, 1870, owned by G. H. Boardman, West Waterville, Me., got by Winthrop Morrill, dam, the well-known Tupper racker, her sire, Norman French, also known as the "Weston horse."

\section{GLENGARRY.}

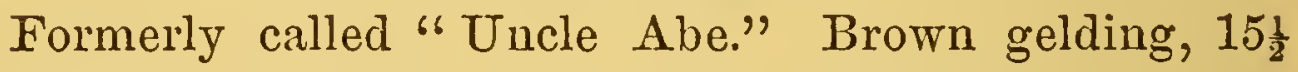
hands high, foaled in May, 1865, bred by Isaac Downing, East Monmouth, Me., got by Winthrop Morrill, dam, a black mare, pedigree unknown.

Downing sold him, when one year old, to George Titus, of Monmouth, he, when three, to John Packard, of Winthrop. Packard sold him to John H. May, of Augusta, for $\$ 1000$. He was afterwards taken to Massachusetts. August 10, 1871, at Buffalo, N. Y., as Uncle Abe, he wòn the 2.50 purse in straight heats, beating nine horses, time, $2.27,2.30 \frac{1}{4}, 2.27 \frac{3}{4}$.

\section{FLEETWOOD.}

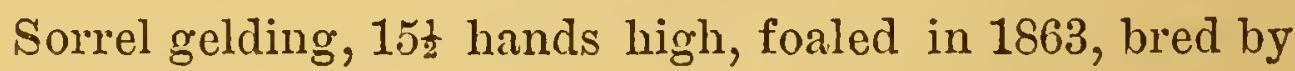


Sheldon Reed, of Madison, Me., got by Winthrop Morrill, dam, a Witherell. He was afterwards owned by Ash Savage, of Waterville, who took him to New York, and he subsequently passed into the hands of Budd Doble. May 24, 1871, at the Point Breeze Park, Philadelphia, Pa., a purse of $\$ 1000$ was offered for horses, that had never started for purse, plate or stake. The race was won by Fleetwood, in straight heats, in $2.37 \frac{1}{4}, 2.35 \frac{3}{4}$, 2.35 . June 6, 1871, at Prospect Park Fair Grounds, he won the three minute race, in straight heats, in $2.31 \frac{1}{2}$, $2.31 \frac{1}{2}, 2.32$.

Sept. 7, at Troy, N. Y., he won a race in straight heats, beating Medoc, Lady Ross, Charlie Green, Ben. Starr, Lady Sheridan, Dreadnaught, Gray Jack and Shepard Knapp, Jr; time, 2.31, 2.29, $2.30 \frac{3}{4}$.

\section{SAM CURTIS.}

Bay gelding, with black points, $15 \frac{3}{4}$ hands high, foaled in July, 1866, bred by Newton Packard, of Winthrop, Me., got by Winthrop Morrill, dam, by Old Eaton. Packard sold him to I. Bonney, of Winthrop, when two years old, and Bonney sold him when four to Charles Gassett, of Boston.

Sept. 12, 1872, at the Mystic Park Fall meeting he won the race for horses that never beat 2.40 , in three straight heats in $2.33 \frac{1}{4}, 2.34,2.34$. July 11,1873 , he won a race.in straight heats at the Mystic Park against Lady Wentworth and Royal Mike, in $2.37 \frac{3}{4}, 2.35,2.34 \frac{3}{4}$.

\section{BABY BOY.}

White gelding, 15 hands high, foaled in 1865, bred by Emmons Williams, of Readfield, Me., got by Winthrop 10 
Morrill, dam, a gray mare of Messenger descent. John Packard bought him and sold him to Richardson \& Warner, and they sold him to Charles Gassett, of Boston.

In 1873, at the New England Fair at Mystic Park, Boston, he won the 2.40 race, winning the last three out of six heats in 2.36, 2.39, 2.30. The next week, Sept. 12, at Lawrence, he won the 2.40 purse in a field of seven, the fastest heat being 2.38. The next day, at the same place, he won the 2.38 race in straight heats in $2.33 \frac{1}{4}$, 2.34 $\frac{3}{4}, 2.35$. Sept. 20 , he won a race at Worcester in three straight heats, the fastest being 2.37 .

\section{MODOC.}

Chestnut gelding, with small star in forehead, and two white stockings behind, $15_{\frac{1}{2}}$ hands high, foaled in 1864, bred by Francis Hunt, Readfield, Me., got by Winthrop Morrill, dam, pedigree not traced. Hunt sold him to George Craig, of Readfield, and he was carried to Massachusetts in 1868, and sold to Levi Gould, of Melrose. In - 1873, July 31, at Beacon Park, Boston, in a race for horses that never beat 2.50 , he won in three straight heats, beating a field of six; the fastest heat was $2.39 \frac{1}{2}$.

At the Fall meeting of the Mystic Park, Boston, Oct. 15 and 16,1873 , in a race for horses that never beat 2.37, Modoc won the fifth heat in $2.33 \frac{1}{2}$. Nov. 5, at Providence, R. I., Modoc won the 2.33 race in straight heats in

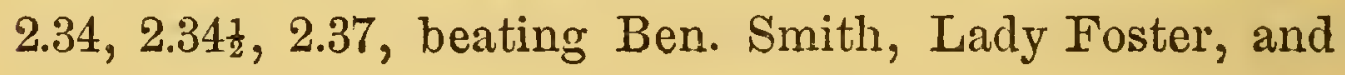
King William.

\section{BARNEY KELLEY.}

Brown bay gelding, with black points, $15 \frac{1}{4}$ hands high, foaled in 1865, bred in Sweden, Me., got by a son of the 
old Morrill horse, of Vermont, who was brought to Fryeburg from Littleton, N. H. His dam was of Morgan descent.

Brad Damon, then of Bridgton, bought him when quite young, and afterwards moving to North Buckfield, he took him with him, the colt being then four years old, and he was always known in Buckfield as the "Damon colt." Damon sold him to the Heald Bros., and they to Samuel Records, of Buckfield, and George C. Gould, of Huntington, Long Island, and he was taken to New York in 1870. In 1873, Mr. Gould sold him to William Lovell, the owner of American Girl. August 5, 1873, at Buffalo, N. $Y$., in a race with Mambino Gift, Mambrino Star, Stewart Maloney, Zilcaadi Goldust, Caledonia Chief, Kate Gilbert, Bay Henry, Manhattan and Planter; Barney Kelley won the second heat, and a record of $2.26 \frac{1}{4}$, and was second in the race.

\section{NELLIE OTIS.}

Chestnut mare, with mane and tail same color, $15 \frac{1}{4}$ hands high, foaled in 1866, bred by Henry Packard, of Winthrop, Me., got by Winthrop Morrill, dam, by Old Eaton.

Packard sold her to Cobb \& Snell, of Winthrop; they sold her to Benjamin Otis, of West Waterville, and he to Mr. Flagg, of Boston, Mass.

\section{SWEET BRIAR.}

Sorrel mare, $15 \frac{1}{2}$ hands high, foaled in April, 1865, bred by Eben Libby, of Wayne, Me., got by Winthrop Morrill, dam, pedigree unknown. Libby sold her to Henry Day, of Leeds, he to Frank Hoyt, of Winthrop, when three years old, and she was called "Lady Hoyt." Hoyt 
sold her to J. F. Jackson, when four years old, he to Major P. C. Bradford, and he to Mr. Everett, of Boston, for $\$ 2000$. At the Fall meeting, at the Mystic Park, in 1872 , in the three minute race, Sweet Briar won the first heat in $2.32 \frac{1}{2}$, and the sixth in $2.34 \frac{1}{4}$.

\section{PURITY.}

Chestnut mare, $15 \frac{1}{4}$ hands high, foaled in 1864, bred by C. G. Jackson, Winthrop, Me., got by Winthrop Morrill, dam (the dam of Ben. Morrill), by Old Columbus. Henry Day bought her, in 1868, when four years old, and sold her in 1872, to Prudent Letourneau, of West Waterville, Me.

\section{LADY TAYLOR.}

Bay mare, $14 \frac{3}{4}$ hands high, foaled in 1866 , bred by William Taylor, of Wayne, Me., got by Winthrop Morrill, dam, by Old Witherell. Taylor sold her, when five years old, to J. F. Jackson, of Winthrop.

\section{MUMM.}

Brown gelding, with star in the forehead, 15 hands high, foaled in 1868, bred by Frank Wadsworth, Hiram, Me., got by Morrill Prince, by Young Morrill, dam, a chestnut mare of Morgan descent. Wadsworth sold him when two years old to John Landers, of Portland, Me., and he was subsequently purchased by Dr. S. H. Tewksbury. While owned by him he got a record of 2.38 at Lewiston.

\section{BELLE GIBBS.}

Sorrel roan mare, with stripe in face, 15 hands high, foaled in 1863, bred by Col. Jameson, Cornish, Me., got 
by Morrill Prince (the sire of Mumm), dam, pedigree not traced. She was subsequently purchased by Stephen Gowen, Biddeford. Fastest record, 2.38, at Biddeford.

\section{DOCTOR.}

Bay gelding, $15 \frac{1}{2}$ hands high, foaled in 1865 , bred by Enoch Leach, Monmouth, Me., got by Winthrop Morrill, dam, a mare brought from Boston, by C. G. Jackson, pedigree unknown. Major Bradford, of Winthrop, bought him and sold him in April, 1873, to Boston parties for $\$ 2000$.

\section{SAM MORRILI.}

Brown colt with no white marks, foaled in 1872 , bred by Samuel Jackson, of Winthrop, Me., get by Winthrop Morrill, dam, a Black Hawk. J. F. Jackson bought him when four months old; afterwards owned by Mr. Wm. Beals.

\section{BALLARD.}

Black colt with star in forehead, and one white ankle behind, foaled in 1870, bred by Jabez Ballard, of Augusta, Me., got by Winthrop Morrill, dam, Iaady Cushnoc. Sold to Messrs. Wright \& Norcross, of Manchester, Me.

\section{JOE HOPKINS.}

Brown stallion, with two white hind feet, foaled in June, 1870, bred by Joseph Hopkins, of Monmouth, Me., got by Winthrop Morrill, dam, by Old Eaton. Hopkins sold him to A. C. Rowe, of East Winthrop. 
JOHN BUNYAN.

Bay stallion, with black points, foaled June 10, 1867, bred by J. M. Brown, Hanover, Me., got by Green Mountain Morrill, by Old Morrill, dam, by Old Hazard, $2 d$ dam, by Kilgore horse.

\section{FLORA MORRILL.}

Bay filly, with black points, foaled May 11, 1871, owned by Samuel Kennedy, Whitefield, Me., got by Flying Morrill, dam, of Messenger descent.

\section{BETSEY TROTWOOD.}

Bay filly, with black points, foaled July 4, 1871, owned by C. W. Kimball, Rumford Point, Me., got by John Bunyan, dam, of Morgan descent.

\section{FANNY.}

Bay filly, with black points, and small star in forehead, foaled May 10, 1870, bred by D. W. Gardiner, Lewiston, Me., got by Young Morrill, of Mass., dam, Black Hawk and thoroughbred.

\section{MIL DER.}

Gray mare, 15 hands high, and weighs 975 pounds, foaled in 1868, owned by Henry C. James, West Waterville, Me., got by Winthrop Morrill, dam, of Messenger descent.

\section{LADY MAY.}

Bay filly, foaled in 1871, bred by Joshua Blinn, Dresden Mills, Me., got by Winthrop Morrill, dam, Nellie (the dam of Blinn Morrill), grand-dam, by Indian Chief. 


\section{DOLIT VARDEN.}

Chestnut filly, with white star in forehead, foaled June 25, 1872, bred by A. W. Brainerd, Readfield, Me., got by Young Winthrop Morrill, dam, Witherell and Eaton.

\section{BRADFORD MORRILL.}

Black colt, with one white ankle behind, foaled in 1871, bred by Major P. C. Bradford, Winthrop, Me., got by Winthrop Morrill, dam, by Hiram Drew.

\section{FANNY MORRILL.}

Dark bay filly, with black points, and star in forehead, foaled June, 1871, owned by G. C. Goodale, Hartland, Me., got by Charlie Morrill, dam, by French Tiger.

\section{GRAY JACKET.}

Gray colt, foaled June, 1871, owned by G. C. Goodale, Hartland, Me., got by Charlie Morrill, dam, a gray mare, of Messenger descent.

\section{EADY MORRILL.}

Chestnut filly, foaled May 26, 1873, bred by Luther Kimball, Bridgton, Me., got by Hiram Morrill, by Winthrop Morrill, dam, Speedaway, by Paul Cook.

\section{GEN. GRAN'T.}

Blood bay stallion, 16 hands high, foaled May, 1870, owned by H. \& J. Stackpole, Thomaston, Me., got by Winthrop Morrill, dam, by Imported Wizard King. 
MORRILL BOY.

Mahogany bay stallion, $15 \frac{1}{2}$ hands high, foaled June 18, 1869, owned by Geo. D. Wakefield, West Gardiner, Me., got by Flying Morrill, by Old Morrill, of Vermont, dam, by Indian Chief.

\section{MORRILL MAID.}

Brown filly, foaled 1872, owned by A. H. Rice, West Waterville, Me., got by Winthrop Morrill, dam, by Witherell.

\section{DAN MORRILL.}

Sorrel colt, with light mane and tail, and two near white feet, foaled in 1872, owned by A. H. Rice, West Waterville, Me., got by Winthrop Morrill, dam, pedigree unknown.

WINTHROP MORRILL, JR. (HAYWOOD'S).

Light chestnut stallion, $15 \frac{1}{4}$ hands high, foaled in 1867 , owned by Henry F. Haywood, Winthrop, Me., got by Winthrop Morrill, dam, by Old Witherell.

\section{BUDD DOBLE.}

Bay gelding, with two white ankles behind, foaled in 1869 , owned by Hiram Reed \& Son, Augusta, Me., got by Winthrop Morrill.

\section{SUNBEAM.}

Sorrel colt, with three white feet, and.star in forehead, foaled June 13, 1871, bred by H. A. Archer, Fairfield Centre, Me., got by Winthrop Morrill, dam, the pacing mare Shoo Fly, by Rising Sun. 


\section{DOLLY VARDEN.}

Bay filly, with white stripe in face, and two white hind feet, foaled May 11, 1870, bred by D. A. Cony, Augusta, Me., got by Young Winthrop Morrill, dam, the Messenger mare, Bess.

\section{HONEST HARRY.}

Roan colt, 15 hands high, foaled 1869 , owned by C. E. Howard, South Litchfield, Me., got by Winthrop Morrill, dam, of Messenger descent.

\section{DEXTER MORRILL.}

Black stallion, with white stripe in face, and four white legs, foaled April 11, 1872, bred by Prudent Letourneau, West Waterville, Me., got by Winthrop Morrill, dam, by Gen. Knox.

\section{BELL MORRILL.}

Dark brown filly, with white star in forehead, and one white ankle behind, foaled in 1872, owned by Wallace Wilshire, Hartland, Me., got by Winthrop Morrill, dam, of English blood.

\section{CHARLIE MORRILL.}

Bay stallion, with black points, foaled June, 1867, owned by G. C. Goodale, Hartland, Me., got by Winthrop Morrill, dam, by Vermont Black Hawk.

\section{LADY SNELL.}

Black filly, foaled in 1872, owned by Geo. E. Wardwell, Monmouth, Me., got by Winthrop Morrill, dam, not traced. 


\section{HAMPTON STOCK.}

\section{HAMPTON.}

This horse is a splendid golden chestnut, with dapples, stands $16 \frac{1}{4}$ hands high, and weighs twelve hundred pounds, and is said to be "not only one of the best bred, but one of the finest looking horses in America." He is coming rapidly into favor, and is destined, we think, to become the progenitor of a distinct and valuable family of horses. He was foaled in 1861, bred by Wm. Sparks, in Orange County, New York, got by Jupiter, he by Long Island Black Hawk, by Andrew Jackson, by Young Bashaw, he by Imported Bashaw. The dam of Hampton was by Kildare, he by Imported Scotch Highlander. He was brought to Maine in 1865, and is now owned by J. S. Lyford, Esq., of Lewiston. Perhaps the best of his get is the promising young stallion,

\section{KING WILLIAM.}

This horse is a blood bay, with very heavy black tail and mane, sixteen hands high, and is what horsemen term a "level made and well balanced young horse." He was foaled in 1866, bred by Col. Golder, Phipsburg, Me., got by Hampton, dam, Witherell Messenger, and is now owned by J. W. McDuffee, Esq., of Lewiston. 
He won, in 1871, when five years old, three races, out of four in which he started, and obtained the distinction of getting a record of 2.40, at the New England Fair, of 1871. August 31, 1871, he beat a field of six horses, at the Forest City Park, Portland.

Sept. 6, at Lowell, Mass., he won in three straight heats, in $2.40,2.43 \frac{1}{2}, 2.42$. His last race for that year was trotted Sept. 28, at the Horse Fair given by the Presumpscot Park Association, at Portland. This race, which was for all five-year olds, he.won, beating five horses, and trotting the fifth heat in $2.42 \frac{3}{4}$, and the following day he trotted a quarter in 37 seconds. Although beaten several times in 1872, he sustained his reputation as a fast and game horse.

Thursday, Oct. 10, 1872, he won a race at the Lewiston Driving Park, trotting the last half of the last mile in 1.16.

Mr. McDuffee was offered ten thousand dollars for him, at the New England Fair, in 1871, and he has been awarded one first premium in his class, at New England Fair, and two at State Fairs. June 10, 1873, he won the 2.40 race at the Forest City Park, Portland, beating John

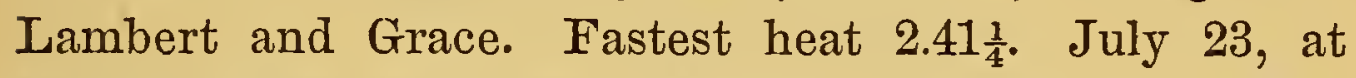
Kenoza Park, Haverhill, Mass., he won the race for horses that never beat 2.37 in three straight heats, in $2.41 \frac{1}{2}, 2.40,2.41 \frac{1}{2}$. 'July 25 , two days after, at the same place, he won the 2.40 race. The first heat was won by Little Dick, and the second, third and fourth heats by King William, in $2.36,2.37 \frac{1}{2}, 2.36 \frac{1}{2}$, trotting the last half mile, in the fourth heat, in 1.15 .

July 31, at the Beacon Track, Boston, in a race for horses that never beat 2.35 , he won the first heat in 2.34 , and the third in $2.34 \frac{3}{4}$, but lost the race. 


\section{ADMIRAL DOT.}

Golden chestnut stallion, $15_{\frac{1}{2}}^{1}$ hands high, and weighed 965 pounds, foaled June 19, 1868, bred by Alfred Cobb, Brunswick, Me., got by Hampton, dam, of Messenger descent.

\section{KING HIRAM.}

Bay stallion, with black points, foaled in June, 1872, owned by Moore \& Decoster, Buckfield, Me., got by Hampton, dam, by Young Tobin.

\section{KING PHILIP.}

Chestnut gelding, foaled May, 1871, bred by Silas Mitchell, Buckfield, Me., got by Hampton, dam, a mare of Morgan descent, formerly owned by Hon. F. O. J. Smith.

\section{MESSENGER PRINCE.}

Gray colt, foaled May 3,1873, bred by J. W. Thompson, Hartford, Me., got by King William, dam, by a son of Old Hunton, 2d dam, by Whalebone.

\section{PRINCE WILLIAM.}

Dark bay stallion, foaled in 1872, owned by S. E. McClellan \& Son, Saccarappa, Me., got by King William, dam, Lady Eaton.

\section{EASTERN KING.}

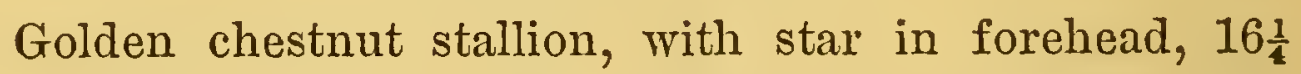
hands high, and weighs 1000 pounds, foaled in.1870, bred by $\mathrm{H}$. H. Dickey, Lewiston, Me., got by Hampton, dam, of Messenger descent. Sold when three years old to A. H. Allen, of Boone Co., Ill. 
HAMPTON, JR.

Bay stallion, with black points, $15 \frac{1}{4}$ hands high, foaled in 1868, owned by J. S. Lyford, Lewiston, Me., got by Hampton, dam, by Davis horse, by Quimby Messenger.

\section{HASKELI HORSE.}

Gray stallion, 15 hands high, and weighs about 925 pounds, foaled in August, 1868, bred by Simeon Haskell, of Auburn, Me., got by Hampton, dam, by the Haskell horse (so called), of Messenger descent.

\section{LADY HAMPTON.}

Light bay filly, with black points, foaled May 24, 1872, bred by C. F. Millett, Norway, Me., got by Hampton, dam, by Live Oak, 2 d dam, by Whirlwind.

\section{BONNEY HAMPTON.}

Bay stallion, with black mane and tail, white star in forehead, and nigh hind foot white, foaled May 12, 1870, bred by John E. Bonney, Turner, Me., got by Hampton, dam (the dam of Shepherd Knapp, Jr.), by Royal Oak. When three years old he weighed 1080 pounds, and stood 16 hands high.

\section{COLONEL HAMPTON.}

Blood bay gelding, with black points, foaled June 2, 1871, bred by Geo. D. Bisbee, Buckfield, Me.; got by Hampton, dam, Lady Morrill, said to be by a Morrill horse, out of a thoroughbred mare.

\section{FLASH.}

Gray mare, $15_{\frac{1}{2}}^{\frac{1}{2}}$ hands high, foaled May 23,1870 , bred 
by J. M. Brown, Hanover, Me., got by Hampton, dam, by Old Hazard, grand-dam, by the Kilgore horse.

\section{EDGECOMB MARE.}

Bay mare, with black points, $15_{\frac{1}{2}}^{\frac{1}{2}}$ hands high, foaled in 1867, bred by Dr. Edgecomb, of Auburn, Me., got by Hampton. Edgecomb sold her, in 1873, to Isaiah Pompilly, of Auburn, and he sold her shortly afterwards to Boston parties for about $\$ 2000$.

\section{OXFORD BOY.}

Bay colt, with black points, and star in forehead and spot on nose, foaled July 19, 1873, got by Hampton, dam, by Old Hazard, grand-dam, by Golden Robin, bred by J. M. Brown, Hanover, Me.

\section{MIGNONETTE.}

Chestnut filly, with light mane and tail, foaled May 10, 1873, bred by Ephraim Childs, Canton, Me., got by King William, dam, Valley Maid, a fast trotting mare, owned by Mr. Childs, pedigree unknown. 


\section{PATCHEN STOCK.}

\section{TOM P.ATCHEN.}

This very speedy representative of the Patchen Family, formerly called "Bill Wellman," is a brown stallion, with a white star in the forehead, $15 \frac{3}{4}$ hands high, bred in New Jersey, got by the celebrated trotting stallion George M. Patchen, dam, said to be by thoroughbred May Day, which is the same cross that produced the renowned "Lucy." Tom. Patchen was first brought to Maine, in 1867. He was entered in a race at the Forest City Park, Sept. 13, 1867, and in "scoring up" he broke his off hind leg, which incapacitated him from trotting. He was afterwards taken to Boston, but in April, 1869, Mr. Gilbert Fowler, of Portland, bought him and brought him to Maine, and he stands for service at his stable, at 74 Clark street, Portland.

\section{HIGHLAND PATCHEN.}

Bay stallion, with black points, $15 \frac{1}{4}$ hands high, foaled June 20, 1870, bred by Holbrook \& Tewksbury, Highland Farm, Oxford, Me., got by Tom Patchen, dam, Witherell Messenger.

\section{ANDY PATCHEN.}

Black stallion, with star in forehead, foaled May, 1871, bred by Sylvanus Porter, Yarmouth, Me., got by Tom 
Patchen, dam, a fast mare of Morgan descent. Porter sold him, when one year old, to James Leighton, of Gray, for $\$ 600$.

\section{BELLE PATCHEN.}

Gray filly, foaled 1870, bred by Irving Blake, Portland, Me., got by Tom Patchen, dam, Belle Winthrop.

\section{JULE.}

Dark bay filly, foaled June 20, 1870, owned by R. O. Conant, Portland, Me., got by Tom Patchen, dam, by Rocky Mountain.

\section{BENICIA BOY.}

Bay gelding, with black points, foaled in 1870 , bred by S. W. Thompson, Bowdoinham, Me., got by Tom Patchen, dam, of Morgan descent.

\section{BURNHAM PATCHEN.}

Bay stallion, with star in forehead, and two white hind feet, foaled June 4, 1870, bred by Dr. S. H. Tewksbury, Portland, Me., got by Tom Patchen, dam, a fine Drew mare, 2d dam, by Flying Eaton.

\section{BLACK HAWK PATCHEN.}

Black stallion, foaled in 1869, bred by G. Fowler, Port- land, Me., got by Tom Patchen, dam, a Black Hawk mare.

\section{GIFFORD PATCHEN.}

Mahogany bay stallion, with star, foaled in 1870 , bred by Ira C. Doe, of Saco, Me., got by Tom Patchen, dam, 
by Gifford Morgan. Doe sold him, when one year old, to G. Fowler, Portland, and he sold him, when three, to James Hill, of St. Stephens, New Brunswick.

\section{BRIGHAM YOUNG.}

Brown gelding, with star in forehead, and one white hind foot, foaled May 5, 1872, bred by J. F. Libby, Portland, Me., got by Tom Patohen, dam, a Kentucky bred mare.

\section{KING'S PATCHEN.}

Black stallion, foaled in 1871, owned by L. D. King, West Gray, Me., got by Tom Patchen, dam, a Black Hawk mare.

\section{PATCHOULI.}

Roan mare, with small star in forehead, foaled June 23, 1871, bred by Irving Blake, Portland, Me., got by Tom Patchen, dam, the L. D. M. Swett mare, by Rysdyk's Hambletonian, a tremendous road mare.

\section{GILBERT.}

Brown gelding, with white stripe in the face and white heels behind, foaled May 30, 1871, bred by Irving Blake, Portland, Me., got by Tom Patchen, dam (the dam of Revenue), by Imported Young Brandywine.

\section{TOM F. PATCHEN.}

Bright bay stallion, with black points, very little white on both hind feet, and small white star in the forehead, 16 hands high, and weighs about 1000 pounds, foaled Sept. 
13, 1869, bred by George S. Farnsworth, North Bridgton, Me., got by Tom Patchen, dam, a light gray mare, of Messenger descent. Owned by Dr. C. H. Farnsworth, of East Cambridge, Mass.

\section{MAY QUEEN.}

Bay filly, foaled May 14, 1872, bred by: A. S. Parker, Skowhegan, Me., got by Kendall's Patchen, a grand-son of George M. Patchen, dam, Kitty, by Witherell.

\section{BIILY PATCHEN.}

Black stallion, with white hind feet and stripe in face, foaled in July, 1870, owned by Bishop \& Alexander, North Harpswell, Me., got by Tom Patchen, dam, the Leavitt mare (so called), of Portland. 


\section{CADMUS STOCK.}

\section{CADMUS.}

In 1866, Mr. Obadiah Whittier, of Vienna, Me., brought into the State, from the stud of Daniel McMillan, Esq., of Greene County, Ohio, several fine animals, among them a one year old stallion, out of a Cadmus mare, got by R. A. Alexander's "Ben Butler," said to be the finest thoroughbred horse in Ohio. Although he has passed out of Mr. Whittier's hands, Cadmus has stood for service in the State up to the present time. His get are quite numerous, and said to be very promising.

\section{CADMUS, JR.}

Dark sorrel stallion, $15 \frac{1}{2}$ hands high, foaled June, 1869, bred by Obadiah Whittier, of Vienna, Me., got by Cadmus, dam, a Call mare. Whittier sold him, when two years old, to Daniel Hanscom, Hallowell, Me.

\section{MAINE ECLIPSE.}

Chestnut stallion, foaled June 28, 1871, owned by Brown \& Hilton, North Anson, Me., got by Cadmus, dam, by Ben Butler. 


\section{PRINCESS.}

Sorrel filly, with small white star in forehead, foaled May 23, 1873, bred by W. P. \& H. N. Atherton, Hallowell, Me., got by Cadmus, dam, Fanny Hathorne.

\section{ENTERPRISE.}

Light bay colt, with black points, foaled June 19, 1873, bred by John Hallowell, Windsor, Me., got by Cadmus, dam, of Messenger descent.

\section{FRENCH CADMUS.}

Bay stallion, with black points, 15 hands high, foaled in June, 1870, owned by Chas. H. H. French, Vienna, Me., got by Cadmus, dam, of Morgan descent. 


\section{ANNEIELD STOCK.}

\section{IMPORTED ANNFIELD.}

Thoroughbred bay stallion, with black points, small star in forehead, and white feet behind, 16 hands high, and weighs over 1100 pounds. This animal was selected by the special agent of the Nova Scotia Government, and first brought from England to Nova Scotia, where he was purchased by Mr. T. S. Lang, and brought to Maine in 1868, to improve our stock of breeding mares. He was bred in England, and was a successful runner, winning the Goodword and New Market stakes, and running second in the English Derby. He was got by Confessor General, dam, Eugenie, by Barbarian, (Bruce's Stud Book, Vol. 1.) In 1871, he was purchased by Holbrook \& Tewksbury, and taken to the Highland Farm, Oxford, Me. Among his get are the following:

\section{ANN.}

Chestnut mare, foaled 1869, bred by H. G. Abbott, North Vassalboro, Me., got by Imported Annfield, dam, by Homan's Messenger.

\section{VICTORIA.}

Roan filly, foaled 1871, bred by H. G. Abbott, North Vassalboro, Me., got by Imported Annfield, dam, pedigree unknown. 


\section{EUGENIE.}

Sorrel mare, with stripe in face, and off hind ankle white, foaled May, 1869, owned by C. A. Fuller, Fairfield Centre, Me., got by Imported Annfield, dam, a Patchen. mare.

\section{MAY DAY.}

Dark bay mare, with black points, and star in forehead, foaled in 1869, bred by B. R. Hunt, Unity, Me., got by Imported Annfield, dam, of Morgan and Messenger descent.

\section{YOUNG ANNFIELD.}

Black stallion, with stripe on nose, foaled May 31, 1870, bred by Albert H. Lord, Hallowell, Me., got by Imported Annfield, dam, Lady Catherine, by French Tiger.

\section{BELLFLUKER.}

Brown colt, with black points, small star and one white hind foot, $15 \frac{1}{2}$ hands high, foaled May, 1869, bred by Wm. J. Haynes, Smithfield, Me., got by Imported Annfield, dam, a Drew mare.

\section{BLACKSMITH BELLE.}

Blood bay filly, with both hind pasterns and near foward one white, and white spot on the off one extending half way round above the hoof, and star in forehead, foaled July 1, 1873, got by Imported Annfield (2S99), dam, by Black Hawk Napoleon, he by Ford's Black Hawk, and he by the original Vermont Black Hawk, 2d dam, Quicksilver and Messenger. Owned by F. C. Stevens, Canton, Me. 


\section{FEARNAUGHT STOCK.}

\section{FEARNAUGHT.}

Fearnaught was a chestnut stallion, foaled in 1859. He was owned by Col. H. S. Russell, Boston, Mass., and died in 1873. His pedigree, as given in Wallace's American Trotting Register; is as follows: Got by Young Morrill, dam, by the Steve French horse, son of Flint Morgan, by Sherman Morgan, grand-dam, of the Batchelder stock, about Pittsfield, N. H. The Fearnaughts were introduced into Maine by Messrs. Wright \& Norcross, who brought their stock from Massachusetts, and established the Fearnaught Farm, at Manchester.

\section{CARENAUGHT.}

Chestnut stallion, $15 \frac{1}{2}$ hands high, with white star in forehead, and one white fore foot, foaled June 23, 1868, bred by Wright \& Norcross, Fearnaught Farm, Manchester, Me., got by Fearnaught, dam, Lady Richmond, by Iron's Cadmus, the sire of Pocahontas.

Carenaught took the first premium in his class, at the Maine State Fair, in 1873.

\section{MANCHESTER.}

Mahogany bay stallion, with two white feet on the near side, narrow white stripe in face, and snip on nose, $15 \frac{3}{4}$ 
hands high, foaled in June, 1870 , bred by Wright \& Norcross, Fearnaught Farm, Manchester, Me., got by Fearnaught, dam, pedigree unknown.

It is said that Dan. Mace offered $\$ 13,000$ for this colt when three years old.

\section{FEARNAUGHT BEAUTY.}

Chestnut stallion, with three white feet, and snip on nose, over 15 hands high, foaled in June, 1870, bred by Wright \& Norcross, Fearnaught Farm, Manchester, Me., got by Fearnaught, dam, a thoroughbred mare.

\section{SELIM FEARNAUGHT.}

Dark bay stallion, with black points, weighs 1000 pounds, foaled in 1869, bred by R. S. Webber, Richmond, Me., got by Minoken Boy. Owned by John W. Umberhind, of Richmond, Me.

\section{EMERY FEARNAUGHT.}

Dark bay stallion, with black mane and tail, 15 hands high, foaled in 1868, bred by Samuel B. Emery, of Sanford, Me., got by Fearnaught, Jr., formerly owned by Mr. Paul, of South Berwick, he by Old Fearnaught, dam, a Morgan mare. Owned by Samuel W. Berry, Biddeford, Me.

August 21, 1873, at the Forest City Park, Portland, he won a race, beating Palmer Knox, in straight heats, the fastest being 2.41 .

\section{YOUNG FEARNAUGHT.}

Chestnut stallion, with white star and stripe, and white forward feet, $15 \frac{1}{2}$ hands high, foaled June 7,1870 , bred by 
John D'Arthenay, Augusta, Me., got by Fearnaught, dam of Young Fearnaught, Duchess, by Brandywine. At the New England Fair, of 1871, when fifteen months old, $\$ 4000$ was offered and refused for this colt.

\section{ILDERIM.}

Chestnut stallion, with two white feet, and stripe in face, 15 hands high, foaled in 1871, bred by Wright \& Norcross, Fearnaught Farm, Manchester, Me., got by Fearnaught, Jr., dam, a mare brought from the South, during the war, that showed good blood.

\section{LANCET.}

Chestnut stallion, with white on nose, foaled in 1871, bred by J. H. Gilbreth, Kendall's Mills, Me., got by Fearnaught, Jr., dam, a Drew mare. Sold, when a yearling, to David Nevins, Jr., Framingham, Mass.

\section{MODOC BOY.}

Bay stallion, with black points, $15 \frac{3}{4}$ hands high, foaled in June, 1870, bred by Col. A. Lothrop, Jay, Me., got by Minoken Boy, by Fearnaught, dam, by the Stinchfield horse, by Old Eaton.

\section{AUGUSTA.}

Black roan mare, with white star in forehead, foaled in 1870, bred by Wright \& Norcross, Fearnaught Farm, Manchester, Me., got by Fearnaught, dam, Lady Gray, by Old Drew.

\section{CARLOTTA.}

Chestnut mare, with no white marks, foaled in 1869 , 
bred by Wright \& Norcross, Fearnaught Farm, Manchester, Me., got by Fearnaught, Jr., dam, pedigree unknown.

\section{FEARLESS.}

Bay mare, with black points, and no white marks, foaled in 1870, bred by Wright \& Norcross, Fearnaught Farm, Manchester, Me., got by Fearnaught, dam, by American Star.

\section{HATTIE.}

Bay filly, with black points, foaled in 1871, bred by Wright \& Norcross, Fearnaught Farm, Manchester, Me., got by Fearnaught, Jr., dam, out of the Cahill mare, the dam of Gilbreth Knox.

\section{FANNY FEARNAUGHT.}

Dark sorrel mare, foaled in Sept., 1870, bred by D. H. Thing, West Mt. Vernon, Me., got by Minoken Boy, by Fearnaught, dam, Fanny Scribner, by Kennebec Messenger (Blake's).

\section{LADY DIAMOND.}

Dark chestnut filly, with white star in forehead, and spot on nose, owned by Samuel Currier, Jr., Hallowell, Me., got by Fearnaught, Jr., dam, a fast trotting mare, pedigree unknown.

\section{FANNY HATHORNE.}

Mahogany bay mare, with black points, and small star, 15 hands high, and weighs 1030 pounds, owned by W. P. \& H. N. Atherton, Maple Grove Farm, got by Minoken Boy, dam, of Messenger descent. 


\section{CARENAUGHT, JR.}

Chestnut colt, with nigh fore and off hind foot white, and star in forehead, foaled May 21, 1873, bred by W. P. $\&$ H. N. Atherton, Hallowell, Me.

\section{LADY MINOKEN.}

Chestnut filly, foaled May 2, 1871, bred by Daniel B. Pease, Augusta, Me., got by Minoken Boy, dam, Gipsey, by T. S. Lang's Pătchen.

\section{LADY FEARNAUGHT.}

Sorrel filly, foaled May 4, 1S73, bred by Daniel B. Pease, Augusta, Me., got by Carenaught, dam, Gipsey, by T. S. Lang's Patchen.

\section{MODOC CHIEF.}

Black colt, foaled June 2, 1873, bred by B. R. Hunt, Unity, Me., got by Whitcomb's Fearnaught, by Old Fearnaught, dam, Nellie Knox, by Gen. Knox.

\section{FEARNAUGHT CHIEF.}

Chestnut stallion, with two white feet behind, and one forward, white star in forehead, and narrow stripe on nose, foaled May 30, 1872, bred by B. F. Barton, Augusta, Me., got by Fearnaught, Jr., dam, Black Bess, a fast stepping mare, raised in Vermont, pedigree unknown.

\section{BLACK FEARNAUGHT.}

Black stallion, with one white hind fcot, foaled April 30, 1871, owned by E. W. Webb, Augusta, Me., got by Fearnaught, Jr., dam, a fine thoroughbred mare, imported. 


\section{CHESTNUT GIRL.}

Dark chestuut filly, with star in forehead, foaled April 22, 1872, owned by E. W. Webb, Augusta, Me., got by Fearnaught, Jr., dam, the dam of Black Fearnaught.

\section{LIVELY LASS.}

Golden chestnut filly, with star in forehead, foaled April 27, 1872, owned by E. W. Webb, Augusta, Me., got by Fearnaught, Jr., dam, the thoroughbred mare, Tar River.

\section{FEARLESS.}

Dark chestnut filly, with star in face, foaled May 19, 1873, bred by E. W. Webb, Augusta, Me., got by Carenaught, dam, Belle Hight, by Gen. Knox.

\section{MAY DAY.}

Dark bay filly, with black points, foaled May 1, 1871, bred by Charles C. Perkins, New Castle, Me., got by Minoken Boy, dam, pedigree unknown.

\section{BIG FEARNAUGHT.}

Blood bay colt, with black points, and small white star in forehead, foaled Sept. 1, 1872, bred by A. J. Lyon, West Waterville, Me., got by Carenaught, dam, by an imported horse.

\section{GAY FEARNAUGHT.}

Chestnut colt, with star in forehead, foaled May 27, 1873 , bred by Mr. Wixon, Augusta, Me., got by Carenaught, dam, said to be thoroughbred. Owned by John D'Arthenay, Augusta, Me. 


\section{CREMORN.}

Golden chestnut coll, foaled June 10, 1872, bred by William T. Sinclair, Hallowell, Me., got by Fearnaught, Jr., dam, Trustee.

\section{JOE JEFFERSON.}

Chestnut stallion, with white stripe in face, foaled June 12, 1871, bred by D. F. Page, Hallowell, Me., got by Fearnaught, Jr., dam, a three-parts bred mare. 


\section{HAMBLETONIAN STOCK.}

\section{PEQUAWKET.}

Blood bay stallion, with black points, and one white foot behind, stands $16 \frac{1}{4}$ hands high, and weighs full 1200 pounds, foaled June 27,1865 , the property of the late $J$. L. Seavey, of Waterville, Me., got by Gideon, by Rysdyk's Hambletonian, dam, the Seavey mare, by Hiram Drew. He was subsequently purchased, and taken to Oxford county, Me., by James Edgecomb, of Brownfield. He obtained a record of 2.38, at the Maine State Fair, at Bangor, in 1873.

\section{LADY PALMER.}

Gray mare, with black points, owned by Samuel $Y$. Luce, Levant, Me., foaled in 1871, got by Gideon, dam, an Indian Chief mare.

\section{GENTLE ANNIE (LUCE's).}

Gray mare, foaled in 1871, owned by Samuel Y. Luce, Levant, Me., got by Gideon, dam, a Drew mare.

\section{INDIAN CHIEF.}

Buckskin colt, with black stripe on his back, foaled June 8, 1873, bred by Samuel Y. Luce, Levant, Me., got by Gideon, dam, an Indian Chief mare. 


\section{CHARITY.}

Red roan mare, $15 \frac{1}{2}$ hands high, foaled in 1867 , bred by Hanson Clay, Westbrook, Me., got by Gideon, dam, the L. D. M. Swett mare, by Rysdyk's Hambletonian. Clay sold her, when one year old, to Daniel Pride; he when two years old to Irving Blake, of Portland. Blake sold her, when four, to George H. Bailey, he to Dr. S. H. Tewksbury, and he to Dunn Waiton, of New York.

\section{FANNY FERN.}

Dark bay filly, with black points, white star in forehead, and two white hind feet, foaled July 12, 1872, and bred by Chas. B. Dore, North Hermon, got by Maine Hambletonian, dam, by Garibaldi, by Oid Drew.

\section{HARRY SLIP.}

Dark chestnut stallion, with star in forehead, foaled June 12, 1869, and bred by J. G. Hanscomb, Buxton, Me., got by Pequawket, dam, Drew and Messenger.

\section{BELMONT.}

Golden chestnut colt, with star in forehead, and one white hind foot, foaled May 21, 1873, bred by D. C. Lyford, Corinna, Me., got by Ledo, by Rysdyk's Hambletonian, dam, Nellie, by Young Eaton, by Old Eaton.

\section{GIDEON, JR.}

Dark bay colt, three white feet, star in forehead, and spot on the nose, foaled June 17,1873 , bred by Chas. B. Dore, North Hermon, Me., got by Gideon, dam, by Garibaldi, by Old Drew, 2 d dam, Morgan. 


\section{LADY WINFIELD.}

Dark bay filly, with black mane and tail, small white spot on upper lip, and two white feet behind, foaled in June, 1870, at I. M. Austin's in Canton, Me., the property of Warren Ward, of New York City, got by Bonner's Edward Everett (formerly Major Winfield), by Rysdyk's Hambletonian, dam, known in New York as the "Sir Henry" mare, pedigree, not traced.

Mr. Ward purchased her dam in foal, by Edward Everett, and sent her to Maine, intending to keep her for breeding purposes.

\section{VIOLET.}

Bay mare, with one white hind foot, foaled in 1866 , bred by the late J. L. Seavey, of Waterville, Me., got by Gideon, by Rysdyk's Hambletonian, dam, the "Seavey mare" (the dam of Echo, Gen. Sherman and Pequawket), by Hiram Drew. After the death of Col. Seavey, this mare was sold, being three years of age, to J. F. Nodine, of Brooklyn, N. Y., for $\$ 1,500$.

\section{MAINE DUROC.}

Brown colt, with black points, foaled July 12, 1873, bred by James Edgecomb, Brownfield, Me., got by Backman's Messenger Duroc (the sire of Prospero), by Rysdyk's Hambletonian, dam, Patchen Maid, by George M. Patchen, grand-dam, by Old Abdallah, sire of Rysdyk's Hambletonian.

\section{JUDGE ADVOCATE.}

Bay colt, with near fore and near hind ankles white, foaled July, 18, 1873, bred by James Edgecomb, Brown- 
field, Me., got by Backman's Messenger Duroc, by Rysdyk's Hambletonian, dam, Lady Pierson, by Neavis' Cassius M. Clay, Jr., 2d dam, by Diamond, by American Eclipse.

\section{MAINE HAMBLETONIAN.}

Dark bay colt, with black mane and tail, near hind foot white, and small stripe in face, foaled June 16, 1873, bred by E. W. Webb, Augusta, Me., got by Beacon, by Volunteer, by Rysdyk's Hambletonian, dam, the thoroughbred mare, Tar River.

\section{TRIUMPH.}

Bright bay stallion, with black points, and small star in the forehead, 16 hands high, foaled May 13,1870, bred by J. C. Mitchell, Bangor, Me., got by Gideon, dam, Kitty, by the Knights horse.

\section{TANNER.}

Bay colt, foaled in 1872, bred by L. R. Morrill, Gorham, Me., got by Pequawket, dam, by Gen. Knox.

\section{LADY LEDO.}

Bay filly, with black points, foaled April 30, 1873, owned by Chas. A. Frost, Corinna, Me., got by Ledo, by Rysdyk's Hambletonian, dam, by Black Sultan.

\section{LEDO, JR.}

Brown colt, foaled May 1, 1873, bred by Sidney A. Thurlough, Newburgh, Me., got by Ledo, dam, Flora. 


\section{CRUISER.}

Bay colt, foaled in 1871, owned by Cairn Simpson, Alton, Me., got by Gideon, dam, of Morgan descent.

\section{ROBERT BURNS.}

Bay colt, foaled June, 1873, owned by Cairn Simpson, Alton, Me., got by Gideon, dam, by Penobscot Chief.

\section{YOUNG DEXTER.}

Colt, foaled May 16, 1873, bred by Ira Goodwin, Dixmont, Me., got by Ledo, by Rysdyk's Hambletonian, dam, Lady Waldo, a black mare, by Telegraph.

\section{LADY GIDEON.}

Dark bay mare, 16 hands high, and weighs 1050 pounds, foaled in 1869, owned by Johnson \& Phair, Presque Isle, Me., got by Gideon, dam, by Flying Morgan, he by Hiram Drew.

\section{HAZEL EYE.}

Bay mare, with black points, and no white marks, $14 \frac{3}{4}$ hands high, and weighs 950 pounds, foaled in 1869, bred by Mr. Hight, Palmyra, Me., got by Gideon, dam, a black mare, bred in Vermont. Hazel Eye was subsequently purchased by A. M. Eaton, Detroit, Me.

\section{PANIC.}

Brown filly, with black points, and no white marks, foaled May 19, 1873, bred by Mr. Tibbetts, Corinna, Me., got by Ledo, dam, by Black Hawk Telegraph, grand-dam, believed to be of Messenger descent. Panic is now owned by Charles Shaw \& Son, Detroit, Me. 


\section{YOUNG HAMBLETONIAN.}

Bay stallion; with black points, $15_{\frac{1}{2}}$ hands high, foaled in 1868, owned by Elisha W. Shaw, got by Gideon, dam, of Messenger descent.

\section{SEEBOOMOOK.}

Bay stallion, with black points, foaled in 1869 , bred by W. W. Chenery, Belmont, Mass., got by Ledo, by Rysdyk's Hambletonian, dam, Vistula, by Imported Scythian. This fine animal was purchased and brought to Maine by Gen. Wm. S. Tilton, Togus, Me., where he stood for service. At the Maine State Fair, at Bangor, in 1872, he took the first premium in his class. In March, 1873, he was being led out by his groom, when he reared, and fell, striking his head on the frozen ground, killing him instantly. His death was a serious loss to the breeders of Maine. The following embraces all his get:

\section{BENSEEBOO.}

Bay colt, witb star, one side of off hind foot white, foaled May 4, 1873, bred by Gen. W. S. Tilton, Togus, Me., got by Seeboomook, dam, Topsey, a black mare raised in M.t. Holley, N. J., said to be by a son of Rysdyk's Hambletonian.

\section{BONAFIDE.}

Sorrel filly, with one fore and one hind white stocking, and white face, foaled May 3, 1873, bred by Gen. W. S. Tilton, Togus, Me., got by Seeboomook, dam, by O'Meara, a son of Glencoe, 2d dam, by Imported Albion. Owned by John D'Arthenay, Augusta, Me. 


\section{BERTRAM.}

Bay colt, with small star, foaled May 8, 1873, bred by Gen. W. S. Tilton, Togus, Me., got by Seeboomook, dam, said to be Black Hawk. Owned by Larkin Trask, Chelsea, Me.

\section{BLITHSOME.}

Brown filly, foaled May 14, 1873, owned by Jefferson Clark, Augusta, Me., got by Seeboomook, dam, by Hector, 2d dam, by Golden Robin.

\section{BELLONA.}

Bay filly, with small star and stripe, foaled May 12, 1873, owned by Gen. W. S. Tilton, Togus, and C. R. Milliken, Portland, got by Seeboomook, dam, Belle Winthrop.

\section{BARON.}

Bay colt; foaled July 19, 1873, bred by Gen. W. S. Tilton, Togus, Me., got by Seeboomook, dam, May, by Gen. McClellan.

\section{BRENDA.}

Bay filly, foaled June 30, 1873, bred by Gen. W. S. Tilton, Togus, Me., got by Seeboomook, dam, the Ricker mare, by Gen. Knox.

\section{BAY BEAUTY.}

Bay filly, foaled July 28, 1873, bred by Gen. W. S. Tilton, Togus, Me., got by Seeboomook, dam, Strip, by a son of Indian Chief. 


\section{BLESBOK.}

Bay filly, foaled July, 1873, got by Seeboomook; dam, Buchanan mare.

\section{BRIGHTHOPES.}

Bay filly, with star in forehead, and one-half of nigh hind pastern white, bred by Gen. W. S. Tilton, Togus, Me., got by Seeboomook, dam, Sally Wright, by American Star.

\section{BAFFLER.}

Bay colt, foaled June 10,1873, owned by Lorenzo Clay, Esq., Gardiner, Me., got by Seeboomook, dam, by Gen. Knox.

\section{JESSIE RIDGLEY.}

Bay filly, with black points, foaled in 1873 , bred by Gen. William S. Tilton, Togus, Me., got by Seeboomook, dam, Ricker Knox, by Gen. Knox. 


\section{MISCELLANEOUS.}

\section{QUICKSILVER.}

Silver gray stallion, at some seasons of the year showing almost black, got by the imported Arabian horse, Dey of Algiers. He was brought from Vermont about the year 1818, by James Pullen, of East Winthrop, and was in the stud at that place, and at Hallowell Cross Roads, now Manchester, till his death, which occurred about 1826 or 1827 . He was brought to Winthrop while the Messenger stock was in the hight of its popularity, and Quicksilver and Winthrop Messenger were for some time rivals in the same town and county. The Quicksilvers were handsome, docile and sprightly, and for a while superseded the Messengers in popularity, but as the Messenger colts came into service, they began to be appreciated, and the descendants of Messenger are every day becoming more and more valued, while the Quicksilvers are nearly forgotten.

\section{EMPEROR.}

Sorrel stallion, with neck very high, and arched, the crest being higher than the head, foaled about 182-, bred and owned by Lemuel Pullen, of Waterville, Me., got by Quicksilver, dam, the Matthews mare, so called. He was a fine horse, and was ridden on military parade, for three 
or four years, about 1830 or '32, by Col. Sanford Pullen, of West Waterville.

\section{STANLEY QUICKSILVER.}

Bright sorrel stallion, looked very much like Emperor, but was shorter legged, more compact, and heavier, was a horse of great endurance, and a fast trotter, foaled about 182-, bred and owned by William Stanley, of West Waterville, Me., got by Quicksilver, dam, the Sanford mare, so called, she out of an imported mare, called the Vase mare.

\section{YOUNG WARRIOR.}

Sometimes called "Gray Eagle." Dapple gray stallion, with mane and tail as white as snow, foaled in 1828, bred by James Pullen, of Hallowell Cross Roads, now Manchester, got by Warrior, he by Quicksilver, dam, the Williamson mare.

Mr. Pullen sold him in 1832, when four years old, to Dexter Pullen, of Waterville, and he was kept in the stud in Waterville for many years. He was a beautiful horse, and in build and action possessed all the characteristics of the Quicksilvers. He got many fine colts. He was ridden, as many will remember, by Gen. Greenleaf White, of Augusta, for two years, at all the musters in the county.

\section{CROOKNECK.}

- Dark sorrel stallion, weighing about 1100 pounds, foaled about 182-, bred by Col. Dennis Blackwell, of West Waterville, Me., got by Stanley's Quicksilver, out of the same mare as Emperor, viz., the Matthews mare. 
When a colt he met with an accident by falling over backwards, striking on his crest, and he never recovered from the injury. He always carried his head to the left, with his neck a little "crooked," hence his name. He was a very powerful horse, but was only broken to the saddle.

\section{BLACKBIRD.}

We find in the "Horse of America," by Frank Forrester, vol. 2, page 159, that in July, 1835, Blackbird made his debut, as a green one from Maine, and beat Richard III. and Master Burke, in straight heats, in 2.55, 2.55, 2.54. He was owned by Mr. George Wilson, of New York, and with his mate, Jerry, both considerably under 15 hands-see Frank Forrester, as above- " formed the pretliest, pleasantest, most gentlemanly looking, and a long way short of being the slowest pair of pony trotting horses I ever saw in the hands of a private gentleman."

\section{GOLDEN ROBIN.}

White stallion, under 15 hands high, foaled in 1832, bred by Alvah Kilgore, of Newry, Oxford county, Me. His dam was a white mare, bred by Peter G. Smith, of Bethel, got by the Israel Thorne horse, so called, of Standish. She was taken to Ohio by the late Phineas Frost, a prominent resident of Bethel, who emigrated to that State with his family in 1831 , but owing to sickness in his family he returned late in the fall of the same year. While in Cleveland, Ohio, his mare was served by a horse called Golden Robin, and after returning to Maine, he sold her to Alvah Kilgore, and the colt was foaled his 
property. He was kept in Newry until the fall of 1843, when he was sold and taken to Mercer, by Ira Kilgore, of that town. He sold him in 1844.

\section{AVERY HORSE.}

Dark chestnut stallion, with dapples, $15 \frac{3}{4}$ hands high, foaled about 1835, bred by Nathan Weston, of Madison, Me., got by a horse called Bucephalus, brought to Maine, in 1833 or '34, by Merrill Blanchard, of Madison. He is described as a large and powerful horse, with white stripe in the face and white stockings behind, his action was long and square, and very open behind. We have been unable to learn anything reliable concerning his pedigree, although it has been said that he came from New York, and was got by Mambrino. The dam of the Avery horse came from Vermont, and is said to be by Sherman Morgan.

Mr. Weston sold him to Dudley Avery, of Anson, and he sold him in 1850 to Wm. Beals, of Winthrop. Mr. Beals sold him to Oren Waterman, he to C. G. Jackson, and he to James Jack, of Portland. He was subsequently purchased by a Mr. Strout, of Lewiston, or vicinity, and died there, suddenly, supposed to be poisoned.

\section{DOLPHIN.}

Sorrel stallion, with stripe in face, and white hind feet, 15 hands high, and weighed about 1000 pounds, foaled about 1832, or '33, bred by Mr. Herbert Savage, of Anson, Me., got by Highlander, a running stallion, brought to Skowhegan, Me., and owned by Jacob N. Shaw. He said that he brought him from New York, and that he was of Messenger blood. The dam of Dolphin 
belonged to what was then known as the Dolphin breed, and from which he took his name. He was a running horse, like his sire, and is thought by many to be the sire of Witherell.

\section{BENSON HORSE.}

Sorrel stallion, 16 hands high, foaled about 1855 , bred by Henry Knights, of Cornville, Me., got by Norman, sometimes called the Crawford horse, a sorrel stallion, $15 \frac{1}{2}$ hands high, brought from Canada, by Mr. Crawford, of Skowhegan, in 1851. He was said to be by a horse called Truedell, and he by a thoroughbred horse, and his dam, a Norman mare. The dam of the Benson horse was by the Burns horse, a sorrel stallion with stripe in the face, bred by Samuel Burns, of Madison, and got by the Avery horse. Inights sold the Benson horse to $\mathrm{Mr}$. Benson, of Madison, hence his name. He was afterward owned by George Wilshire, of Hartland, where he died. He was the sire of Lew Pettee.

\section{YOUNG HOGARTH.}

Chestnut stallion, with light mane and tail, and white stripe in face, 15 hands high, foaled about 1846-48, bred by Mr. Toothaker, Phillips, Me., got by Hogarth, a running horse brought from Nova Scotia, to Hallowell, Me., and it was said came to that Province from England, dam, by Eaton horse. He was owned by different persons, during his life, and for a time by J. C. Miller, Wilton, Me. He sold him to his brother, Nathan Miller.

\section{KNIGHTS HORSE.}

Bay stallion, with black points, 15 hands high, foaled about 1553 or ' 54 , brought to Winthrop, Me., from Massa- 
chusetts, when a colt, by Nelson Knights, of Winthrop. His sire and dam were both imported, dam, said to be thoroughbred, and sire, a Cleveland bay. Mr. William Beals, of Winthrop, bought him in 1864, and he died the following fall. We give all that is known of his pedigree, as many of his get are noted as breeding mares.

\section{DARE.}

Bay gelding, with black points, over 16 hands high, foaled in May, 1865, bred by Charles H. Foss, of Wayne, got by the Knights horse, dam, unknown. Foss let Mr. C. R. Milliken, of Portland, have him, and Sept. 28, 1871, at the New England Fair, at Portland, Me., he won the race for horses that never beat 2.45 , in three straight heats, in $2.39 \frac{1}{4}, 2.40,2.40 \frac{1}{2}$.

\section{JAS. G. BLAINE.}

Black gelding, with no white marks, $15 \frac{3}{4}$ hands high, foaled in 1866, bred by James Blanchard, of Pittston, Me., got by Messenger Hunter, sometimes called the Thing horse, being owned for a time by Mr. Thing, of Hallowell. He came from Massachusetts, and was also owned by Messrs. Wright \& Norcross, of Fearnaught Farm, Manchester.

The dam of Jas. G. Blaine was the Major Lally mare (so called), by the Dr. Call horse, he by thoroughbred Cannon Ball. He was sold, when a sucker, to a Mr. Nickerson, and he sold him, when six years old, to Hiram Reed \& Son, of Augusta, and they, in 1873, to Wright \& Norcross, of Fearnaught Farm. 


\section{FRENCH TIGER.}

Gray stallion, 16 hands high, and weighed about 1350 pounds. He was imported from Canada, and said to be of Norman descent. He was owned by Mr. America Farrar, of Buckfield, afterwards by Charles Proctor, of Corinna. He was a fine horse, and fast.

\section{LADY OXNARD.}

Bay mare, with off hind ankle white, and blaze in face, $15 \frac{1}{4}$ hands high, foaled in 1851, bred by Hiram Jewett, Sangerville, Me., got by French 'Tiger, dam, by Lion Messenger.

After passing through several different hands, she was taken to New York, and became the property of $\mathrm{Mr}$. George T. Wisner, of Goshen, Orange county. Said to have trotted in 2.33 or 34 . In Wallace' Trotting Register her pedigree is given as dam, by Rising Sun, but our information, direct from Mr. Wisner, gives her pedigree as above stated. She is now used for breeding purposes, and is the dam of Freedom, by Rysdyk's Hambletonian.

\section{LADY GAY SPANKER.}

Gray mare, about $15 \frac{1}{4}$ hands high, foaled in 1855 , bred by a Mr. Warren, of Durham, Me., got by French Tiger, dam, by Quimby's Messenger. She was purchased, when five years old, by James Jack, of Portland. George $\mathrm{H}$. Bailey afterwards had her, and she was taken to Mlassachusetts in 1863 or '64. In 1864, at the Riverside Park, Boston, she won a matched race against Lady Wales in 2.42, 2.45. Dec. 9, at the same place, in a race against George Washington, she obtained a record of 2.41. She was afterwards bred to Gen. Knox, and her colt, called. 
Harry Spanker, has a record of 2.35. She was subsequently taken down into the Provinces, where $\mathrm{Mr}$. Bailey found her. In 1873 she was taken to Massachusetts, and bred to Fearnaught, but died during the season.

\section{YOUNG INDIAN · CHIEF.}

Sometimes called the "Lewis horse," was a dark gray stallion, about $15 \frac{1}{4}$ hands high, and weighed about 950 pounds, foaled in 1842, bred by Daniel Boynton, New Portland, Me., got by a small iron gray stallion, that could both trot and pace fast, brought from Canada, about 1830, by T. W. Gale, and called "Indian Chief." The dam of Young Indian Chief, not traced.

When young, he passed into the hands of Darius Lewis, of Hallowell Cross Roads, now Manchester. He was considered fast, and at one time the horse and his stock were considered second to none in the State.

\section{BILLY BUMPUS.}

Brown gelding, with black points, about $15 \frac{1}{4}$ hands high, foaled in 1862, bred by Joseph Ryant, of Eustis Plantation, got by the Butler horse, a dapple gray stallion, weighing about 1000 pounds, he by the "Lewis horse," or young Indian Chief. The dam of Billy Bumpus was a fast pacing mare, light bay, with black points, under 15 hands high. When two years old Mr. Ryant sold him to Capt. Bacon, of Wilton, but he was not taken away from Eustis. He could neither pace nor trot, and was considered almost worthless, and was sivapping property for years, and had many different owners in Eustis and Dead River Plantations, New Portland, etc., and was 
finally worked in a team two winters, not being considered fit for any other business. In 1870 Thomas Ditson, of New Portland, bought him for $\$ 100$. John Moody afterwards bought him, and in his hands he first began to trot. He took him to Livermore, and sold him to Alonzo M. Bumpus, of Livermore Falls. In his hands he gained some laurels in the trotting arena, as "Billy Bumpus."

In 1872, he sold him to Dr. Strout, of Auburn, Me. At Forest City Park, Portland, Me., Oct. 16, 1872, he won a race for horses that never beat 2.40, in three straight

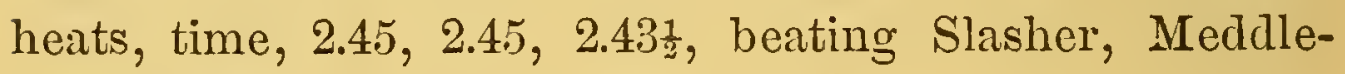
some, Wagram and Auburn Boy.

\section{HECTOR.}

Spotted stallion, 15. John Hale, of Lee, Me., got by a spotted stallion, belonging to a circus, and called an Arabian. He broke his leg in Lee, and was kept there a while for service. The dam of Hector was of Morgan descent. Geo. M. Robinson, of Augusta, bought him, when eight years old, and sold him to Waldo Pierce, of Bangor. From Bangor he went to Boston, and finally to Lyin.

\section{COL. IAKEMAN.}

Spotted gelding, $15 \frac{1}{2}$ hand high, foaled in 1861, bred by Geo. M. Robinson, of Augusta, Me., got by Hector, dam, by the Guild horse.

July 5, 1869, at Rockland, Me., he beat Carlotta, and Lady Chapman, in straight heats, in $2.35,2.39,2.44$. At Narragansett Park, June 14, 1871, he was 4, 3, 4 to Royal John, in $2.27 \frac{1}{2}, 2.27 \frac{1}{2}, 2.26 \frac{1}{4}$. 


\section{AMAZON.}

Roan mare, 15 hands high, foaled in 1860 , bred by Allen Lambard, Esq., Augusta, Me., got by Hector, dam, pedigree unknown. She was afterwards owned by H. B. Virgin, of Rumford, Me., and he sold her in the fall of 1871 to H. W. Brackett, of Dixfield, and he, in 1873, to Sewell Goff, of Mexico. In 1872 she won a race at Skowhegan, with a record of 2.42. June 18, 1873, she won a race at the Lewiston Driving Park, beating Billy Bumpus, fastest heat, 2.40 .

\section{YOUNG RULER.}

Chestnut stallion, 16 hands high, and weighs 1200 pounds, foaled in 1868, bred by Thomas Snell, Ludlow, Me., got by Old Ruler, dam, of Messenger descent. Owned by Daniel D. Hemore, Smyrua Mills, Me.

\section{TOM.}

Steel gray stallion, $16 \frac{3}{4}$ hands high, and weighs 1200 pounds, foaled in 1869, bred by Benjamin Alexander, Linneus, Me., got by Chandler horse, he by Old Nigger, dam, by Plow Boy.

\section{PENOBSCOT BOY.}

Stallion, 15 hands high, foaled in June, 1870, owned by Leander C. Perkins, Penobscot, Mie., got by Young Ruler, pedigree of dam unknown.

\section{CAPT. JACK.}

Dark bay stallion, with star in forehead, and one white hind foot, $15 \frac{1}{2}$ hands high; and weighs about 1025 pounds, 
foaled June, 1868, bred by John P. Snow, and owned in 1873, by Francis Grindell, Penobscot, Me., got by Young Ruler, dam, pedigree unknown.

\section{FARMER BOY.}

Dark bay stallion, with two white feet, weighing about 1050 pounds, foaled June 13, 1870, bred by Nicholas Ober, Surrey, Me., got by Young Ruler, dam, unknown. Owned by Harvey J. Cunningham, Ellsworth, Me.

\section{LEON.}

Light chestnut or sorrel stallion, with light mane and tail, foaled June 11, 1869, bred by J. E. Ginn, Orland, Me., got by the E. Hutchings horse, he by an Arabian horse, dam's pedigree unknown.

\section{GENERAL LIGHTFOOT (LOVEJOY's).}

Black stallion, with star in forehead, and white hind feet, $15 \frac{1}{2}$ hands high, and weighs 975 pounds, foaled in 1869, bred by Alpheus G. Lovejoy, Oxford, Me., got by the Jacob Linnell horse, he. by Black Jack, dam, of Morgan descent, got by the Abbott horse.

\section{BLACK PRINCE (HOWE'S).}

Black stallion, with brown points, 16 hands high, and weighs 1050 pounds, foaled August 4, 1868, owned by W. C. Howes, North Newburgh, Me., got by Defiance (better known as the Whitcomb horse), he by Messenger Hunter, bred by Dennis Hay, Esq., of Boston, he by Imported English Hunter, dam, Messenger, dam of Black Prince, a Black Hawk mare, grand-dam, by thoroughbred Black Snake(?) 


\section{KENDDUSKEAG BOY.}

Dark bay stallion, with black mane and tail, one white fore foot, and one white hind foot, $16 \frac{3}{4}$ hands high, and weighs 1230 pounds, foaled May 19, 1868, bred by O. K. Nason, Kenduskeag, Me., got by a thoroughbred English horse, dam, of Messenger descent. Owned by W. K. \& R. M. Nason.

\section{ZAMOR.}

Sorrel stallion, with white stripe in face, $14 \frac{3}{4}$ hands high, and weighs 875 pounds, foaled May 21, 1869, bred by Stewart Patterson, Hudson, Me., got by Young Champion, by British Champion, dam, a Drew mare, by the Mansell horse, sire of Contraband. Owned by Valentine Patterson, Hudson, Me.

\section{GOLDEN MESSENGER.}

Chestnut stallion, weighing 1180 pounds, foaled in 1868, bred by B. F. Dunham, Dexter, Me., got by Messenger Morgan, formerly owned by Chas. Proctor, of Corinna. Owned by Lucian A. Luce, Dexter, Me.

\section{YOUNG DANVILLE BOY.}

Black stallion, $15_{\frac{1}{2}}^{1}$ hands high, and weighs 1050 pounds, foaled in 1865, got by Danville Boy, Jr., he by Danville Boy, by Old Morrill, dam, of Morgan descent. Owned by James Boston, Wells, Me.

\section{BLACK PRINCE (BAILEY'S).}

Black stallion, weight 1225 pounds, foaled about 1861 , bred by William Dunn, Mount Vernon, Me., got by 
Black Prince, from Prince Edward's Island, dam, of Morgan descent. Owned by S. Bailey, Whitefield, Me.

\section{PRINCE.}

Dark bay stallion, $16 \frac{1}{2}$ hands high, foaled in 1865 , bred by Henry Hussey, Jefferson, Me., gót by Prince of Wales, an English horse, dam, pedigree unknown.

\section{YOUNG BUCHANAN.}

Blood bay stallion, with black points, and no white marks, 16 hands high, and weighs 1050 pounds, foaled in June, 1868, bred by Rufus Littlefield, Prospect, Me., got by Buchanan, 2d, now a gelding called Victor, owned by $\mathrm{F}$. W. Berry, of Belfast, grand-sire, Old Buchanan, great grand-sire, Shute horse, great, great, grand-sire, an English thoroughbred horse(?), which swam ashore from the burning steamer, Royal Tar, in Penobscot Bay, dam, of Young Buchanan, pedigree unknown, brought from Canada.

[The above story, of a stallion swimming ashore from a burning steamer, is believed by many, but we cannot vouch for the truth of it.-J. W. T.]

\section{JOHN.}

Bay stallion, with black mane and tail, 16 hands high, and weighs 1376 pounds, foaled in 1866, bred by David Moore, Plantation No. 11, Aroostook county, got by Champion, dam, by Simpson horse.

\section{BLACK PRINCE (HUTCHIN').}

Black stallion, 16 hands high, and weighs 1240 pounds, foaled in 1866, bred by Stephen Gerow, Hodgdon, Me., 
got by Simpson horse, he by Imported Clydesdale, dam, by Old Nigger(?). Owned by W. T. Hutchins, Houlton, Me.

\section{YOUNG ABE.}

Iron gray stallion, weighing 1100 pounds, foaled in 1868. Owned by Joseph Pease, Presque Isle, Me., got by the Parlin Whitney horse, he by Flying Morgan, dam, of Messenger descent.

\section{COBBLER.}

Sometimes called Young Abdallah. Golden chestnut stallion, with star in forehead, 16 hands high, and weighs 1200 pounds, foaled in 1865, owned by $\mathrm{Wm}$. Lawrence, Houlton, Me., got by Natick Cobbler, he by Meig's Abdallah, dam, unknown, Meig's Abdallah, by Abdallah, dam, a trotter from Canada. Dam of Cobbler, of Messenger descent.

\section{DICK.}

Brown stallion, 15 hands high, and weighs 1000 pounds, foaled in 1869, bred in Madarvaska, Me., owned by Frank Lavine, Ludlow, Me., got by the Forbes horse, he by Herrin's West horse.

\section{BLACK DIAMOND (LAVINE's).}

Black stallion, with white stripe in face, and two white hind feet, foaled in 1869, bred in Madawaska, Me., owned by Frank Lavine, Ludlow, Me., got by an English horse, dam, half French.

\section{WEBSTER BOY.}

Chestnut stallion, with light colored mane and tail, 15 
hands high, and weighs 1060 pounds, foaled in 1870, bred by Cornelius C. McCarty, Webster, Me., got by Lewiston Boy, dam, a common blooded mare.

\section{VAN AMBURGH.}

Black stallion, $16 \frac{1}{4}$ hands high, and weighs 1175 pounds, bred by L. Jackson, Morrill, Me., foaled May 6, 1869, got by Gen. Butler, he by a Messenger horse, dam, a French mare. Owned by S. I. Gurney, Belfast, Me.

\section{.PLOW BOY.}

Black stallion, with star in the forehead, and two white hind feet, $16 \frac{1}{2}$ hands high, and weighed 1220 pounds, when three years old, foaled May 10, 1870, bred by James $\mathrm{H}$. Clark, Northport, Me., got by Black Active, formerly owned by James Nickerson, of Swanville, dam, English and French.

\section{NORMAN ROGER.}

Light sorrel stallion, 15 hands high, foaled June 16, 1870, bred by Alfred L. Callson, Winterport, Me., got by the Smith horse, owned by Albert Smith, of Winterport, of Morgan and Messenger descent, dam, of Province stock.

\section{ROCKET.}

Chestnut stallion, with no white marks, $15 \frac{1}{2}$ hands high, foaled in 1868, bred by Hiram A. Ellis, Esq., Canton, Me., got by Rocket, a chestnut stallion, brought from Massachusetts, and formerly owned by Stephen Hayes, of Natick; he was said to be by Old Columbus, dam, by 
Meig's Abdallah. The dam of Rocket was by Young, Brandywine. Mr. Ellis sold Rocket to J. P. Swasey, Esq., of Canton, and he to Gorham Park, of Canton Point.

[For extended pedigree of Old Columbus and Meig's Abdallah, see Wallace' Trotting Register.-J. W. T.]

\section{OTTO VON BISMARCK.}

Black stallion, with white spot on one hind foot, weighng 1000 pounds, owned by J. C. Rines, Hampden, Me., got by a Black Hawk and Messenger horse, dam, a Fox(?) mare.

\section{TROTTING BILLY.}

White stallion, weighing 1200 pounds, foaled in 1859, bred by Mr. Herrin, Guilford, Me., got by Whalebone Morgan, dam, by Lion Messenger. Owned by A. L. Grant, Corinna, Me.

\section{GENERAL (MERROW's).}

Gray stallion, weighing 950 pounds, foaled in 18556, bred by John R. Merrow, of New Gloucester, Me., got by an imported spotted Arabian horse, dam, by Young Indian Chief.

\section{YOUNG HARDROW.}

Dark chestnut stallion, with black mane and tail, and one white hind foot, foaled in 1870, bred by Ambrose A. Maddocks, Appleton, Me., got by a French horse, dam, a Fox mare.

\section{YOUNG ETHAN ALLEN.}

Blood bay stallion, with black mane and tail, $15 \frac{1}{2}$ hands 
high, and weighs 980 pounds, foaled June 3, 1868, bred by Thomas Stimson, of Limerick, Me., got by Ethan Allen, Jr., he by Ethan Allen., dam, of Morgan descent. Owned by A. O. Libby \& Co., Limerick, Me.

\section{CONQUEROR JUNIOR.}

Iron gray stallion, 16 hands high, and weighs 1175 pounils, at three years of age, foaled in 1870 , bred by Daniel Clark, Wells, Me., got by Imported Percheron stallion, Conqueror, dam, of Messenger descent.

\section{MAY BOY.}

Chestnut stallion, $15 \frac{1}{2}$ hands high, and weighs 1100 pounds, foaled May 10, 1868, owned by Daniel F. Berry, Cornish, Me., got by Caledonia, dam, of Morgan descent.

\section{NORMAN TIGER.}

Bright bay stallion, with white stripe in forehead, about 16 hands high, and weighs 1250 pounds, foaled June 20, 1868, bred by William M. Hattin, Litchfield, Me., got by Black Bill, he by the Ramsey horse, from Vermont, he by the Steele horse, dam, by the Barlow horse, he by an imported Norman horse.

\section{DICK.}

Bay stallion, with black points, and near hind foot white, foaled June 17, 1867, owned by Enoch Weston, Madison, Me., got by Draco, dam, Black Hawk and Witherell. 
PRINCE ALBERT, JR.

Dark bay stallion, $15 \frac{1}{2}$ hands high, and weighs 1082 pounds, foaled April 20, 1864, bred by Edgar Millay, North New Portland, Me., got by Prince Albert, dam, by Flying Eaton, grand-dan, by Morgan Emperor, great, grand-dam, by Indian Chief.

\section{GENERAL (HoLDEN's).}

Dapple gray stallion, 16 hands high, and weighs 1150 pounds, foaled in 1869, bred by Otis Holden, Moose River, Me., got by Eaton Messenger, dam, Julia, by the Webb horse, of Skowhegan.

\section{CHESTNUT DICK.}

Dark chestnut stallion, with star in forehead, and one white hind foot, 15 hands high, and weighs 1200 pounds, foaled in 1862, bred by Daniel Rice, Guilford, Me., got by the Herring horse, called "Trotting Billy," dam, Fan, by a Messenger horse, and out of a Morgan mare.

\section{WELLINGTON BOY.}

Dark sorrel stallion, weighing 1150 pounds, foaled in 1867, bred by James Dodson, Athens, Me, got by the Edward Russell horse, he by Morrill Champion, dam's pedigree unknown. Owned by William Lawrence, Wellington, Me.

\section{BOSTON GIRL.}

Bay mare, about $15 \frac{1}{2}$ hands high, foaled about the year 1836, bred by Mark Pease, of Jackson, Me., got by a horse called Sir Henry, bred by Elder James Lewis, of 
Gorham, Me, he by a son of American Eclipse, taken from Connecticut to Maine by a Dr. Brewster, now dead. Simeon Pease bought Sir Henry in March, 1834, and brought him to Jackson, and in the September following he sold him to his brother, Mark Pease. The dam of Boston Girl was Lady Jane, by Winthrop Messenger, $2 d$ dam, Morgan.

When four years old, Mr. Pease sold her to Wm. Morton, of Exeter, Me., and he sold her to Hiram Drew, also of Exeter. While owned by Mr. Drew she became the dam of the horse afterwards known as the Drew horse. In 1843, Mr. Drew took her to Boston, and sold her to F. W. Lander, afterwards known as Gen. Fred. Lander, and killed during the war. Gen. Lander sold her, and after having several different owners, Dr. Saunders, the veterinary surgeon, bought her of Ives G. Bates, agent for the Inman Steamship Company.

Dr. Saunders sent her up into Vermont, on a farm, and tried several years to get a colt from her, but could not. Her fastest public record, while owned in the vincinity of Boston, is said to be 2.37. She was once known as "Grace Darling."

\section{SORREL HIRAM.}

Sorrel gelding, abont 15 hands high, foaled in 183-, bred by Wm. Wyman, West Waterville, Me., got by Crookneck.

Wyman sold him, when three years old, to Joseph Nudd, of Waterville, and he to Tufton Simpson, of Winslow. Simpson sold him to Benjamin Hodges, of Hallowell, and Hodges to Oliver Walton, of Boston. He got a record of 2.40 , in Boston, and was afterwards taken to New York. "He was a game little horse, and could trot all day." 


\section{INDEPE NDENCE.}

Chestnut gelding, $15 \frac{1}{2}$. high, foaled about 1832, bred by Captain Joshua Wing, of Winthrop, got by Conqueror, a horse brought from Massachusetts, pedigree unknown, dam, by Old Winthrop Messenger. Wing sold him, when six years old, to Oliver Walton, of Boston. In 1839, Nov. 15, he trotted a race, mile heats three in five, against Lady Suffolk, beating hor in $2.45 \frac{1}{2}, 2.45,2.47$. He trotted the same race, the next day, against Lady Suffolk, beating her again. Mr. Woodruff says, "Independence was a good horse. He had not great speed then, but he afterwards got to be very fast." In 1843, on the 4th of July, he trotted a race, mile heats, under saddle, against Lady Suffolk and Beppo, on the old Beacon Course. Lady Suffolk won the first heat in $2.28 \frac{1}{2}$, the second was a dead heat between her and Beppo, in 2.28, the third heat Independence won in 2.28. The fourth and fifth were won by Lady Suffolk.

\section{POST BOY.}

Bay gelding, 15 hands high, foaled in 18-, bred in Belgrade, Me. His pedigree is unknown, but he was said to be of Messenger descent. Oliver Walton, bought him, and took him to Massachusetts, and sold him to John Welch, of Boston, and he to Spencer Vinal. He was afterwards taken to New York. Oct. 23, 1843, at Boston, he beat Dying Sargeant in 2.40, 2.44, 2.45.

\section{DYING SARGEAN'Г.}

Black gelding, $15 \frac{1}{2}$ hands high, foaled about 183-, pedigree unknown. Oliver Walton bought him in Maine, and took him to Massachusetts. He was a desperate puller. 
He trotted at Boston, in Oct., 1843, against Post Boy, winning one heat.

\section{LADY SWAN.}

Chestnut mare, about $15 \frac{1}{4}$ hands high, round hipped, very handsome, with coat as fine as silk, foaled about 1833. Her pedigree, or by whom bred, is at present unknown. She was always said to be of Messenger descent. She was taken to New York from Maine, by John Swan, of Anson, and with the death of Mr. Swan all trace of her former history is lost.

Spencer Vinal, of Boston, brought her to that city from New York; in 1840. June 9, 1840, over the Centreville Course, New York, she beat Duchess, Helen McGregor, and two others, two miles and repeat, in 5.20, 5.23 .

Sept. 26, 1842, she beat Yankee, in straight heats, at Boston, in 2.37, 2.45, 2.45. In Oct., 1840, she became blind, cause unknown. In 1856, when twenty-three years old, Mr. Vinal had her killed, with chloroform, and buried.

\section{HENRY.}

Chestnut gelding, $15 \frac{1}{4}$ hands high, taken from Maine to New York by John Swan, of Anson, and sold to Harry Jones. He was driven for a time in double team with Lady Swan.

Oct. 10, 1839, he beat Celeste, I)on Juan, Cato and Lady Suffolk, two miles and repeat, over the Centreville Course, time 5.20, 5.28. He, also, was said to be of Messenger descent. 


\section{ICE PONY.}

Brown gelding, under 15 hands high, and "handsome as a picture." Ben. Hodges, of Hallowell, traded for him in Brunswick, Me., and nothing is known of his pedigree or early history. Mr. Hodges trained him on the ice, and he was called Ice Pony. Hodges sold him to Ezekiel Simpson, of Waterville, and he took him to $\mathrm{New}$ York and sold him to Harry Jones. Mr. Woodruff says that " he possessed the gift of speed in a remarkable degree." In 1841 he trotted one-half mile, on the Old Beacon Course, in 1.12, "trotting for the juleps."

\section{LICENSE.}

Chestnut gelding, with star in forehead, $15 \frac{1}{4}$ hands high, foaled in 1859. He was taken to Massachusetts from Maine, with some army horses, by a Mr. Savage, and nothing is known of his pedigree. He was placed in the Massachusetts stable, but was rejected, as unfit for the army, on account of his age, as he was found to be but four years old. He afterwards got into horsemen's hands, and was first brought out by E. L. Norcross, from whom we obtained the above information.

He was afterwards owned by D. H. Blanchard, of Boston, and finally by Col. Russell. Sept. 17, 1866, he trotted a race against Gideon Welles, for a purse of $\$ 1000$, winning in three straight heats, in $2.40 \frac{1}{4}, 235,2.39 \frac{1}{4}$. June 28, 1867, he beat Booth in straight heats, in 2.32, $2.34 \frac{1}{4}, 2.39 \frac{1}{4}$, for $\$ 5000$.

August 30, 1867, he beat Ben. Franklin, Col. Maynard and Shepard Knapp, Jr., in straight heats, in 2.34 $\frac{3}{4}, 2.36 \frac{1}{2}$, 2.34, for a purse of $\$ 3000$.

Sept. 17, 1867, he beat McClellan and India Rubber, in straight heats, in $2.29 \frac{1}{2}, 2.32 \frac{1}{2}, 2.31 \frac{1}{2}$. 
Oct. 18, he beat Col. Maynard and Shepard Knapp, Jr., in 2.28, 2.28 $\frac{1}{4}, 2.31$. Nov. 12, he beat Shepard Knapp, Jr., again, in straight heats, time, $2.33 \frac{1}{4}, 2.30 \frac{1}{4}, 2.31 \frac{1}{4}$. All the above races took place at Boston.

Sept. 22, 1870, at Fleetwood Park, New York, he beat Charles L. Loew, J. J. Bradley and Confidence, License winning the first heat in $2.26 \frac{1}{2}$, the fifth in 2.28 , and the sixth heat and race in 2.29 .

\section{BAY WHALEBONE.}

Bay gelding, with black points, $15 \frac{1}{4}$ hands high, foaled about 1862, bred by John McCollister, Norway, Me., got by Whirlwind, a bay stallion, that both paced and trotted, imported from Canada, dam, a small black mare, supposed to be of Morgan descent. McCollister sold him, when four months old to Simon P. Everett, also of Norway. After passing through several different hands, he was sold to Levi Turner, of Buckfield. Turner sold him to David Records, of Buckfield, and he, when six years old, to Charles Records, then of South Weymouth, Mass. He was afterwards purchased by D. H. Blanchard, of Boston. June 22, 1871, at the Beacon Park, Boston, he won the 2.30 race in straight heats, in $2.28 \frac{1}{2}, 2.29 \frac{1}{4}, 2.30$, beating Royal John, Climax, Lydia Thompson, Charlie Green, and others. At the Mystic Park, June 28, 1871, he won the second heat in a race in the fast time of $2.26 \frac{1}{4}$, race won by Royal John.

\section{HONEST BILL.}

Chestnut gelding, 15 hands high, with one white stocking forward and one behind, and white stripe in face, foaled in 1863, bred by William T. Hoar, Rangely, Me. 
But little is known of his pedigree; he was got by a colt that is not otherwise known much about, said to be of Morrill blood, and the pedigree of his dam is also unknown. When three years old, he came into the hands of B. R. Rollins, of Weld. Sept. 28, 1872, at Dixfield, Me., he won a race, beating Dagon (now Buffalo Bill) and Pomp, the fastest heat being 2.43. Sept. 25, 1873, at Farmington, Me., he beat Brown Harry and others, in straight heats, the fastest being $2.40 \frac{1}{2}$.

\section{MADAWASKA MAID.}

Sorrel mare, $14_{4}^{3}$ hands high, and weighs about 850 pounds, with, I think, a small star in forehead, and some white on one hind foot, foaled in 1862, bred by Vetal Aban, Grant Isle, Madawaska, Me., got by an English horse, said to be thoroughbred, and noted for his speed at running, dam, a mare brought from Montreal, pedigree unknown.

G. W. Collins, of Presque Isle, bought her of the man who raised her, and finally sold her, and she was taken to Massachusetts. Oct. 6, 1868, at Boston, in a race with Warwick, Emperor and White Stockings, she won the second heat, and a record of $2.29 \frac{1}{2}$. In 1871 she foaled a filly, called Madawaska Girl, got by Fearnaught. She was afterward taken to New York, and in 1872 was owned and driven on the road by Dr. Corey, in double team, with Commodore Nutt.

\section{BELLE OF BROOKLYN.}

Formerly Kate. Bay mare, with black points, $15 \frac{1}{4}$ hands high, and weighs 880 pounds, foaled in 1861, bred by Alfred Stone, of Wilton, Me., got by the Potter horse, 
he by Old Potter horse, he by a horse brought from the Provinces, said to be of English blood, and out of a mare by Winthrop Messenger. The pedigree of the dam of Belle of Brooklyn is unknown, although she has produced several very speedy colts. Stone sold her to Jason Trask, of Wilton, he to Mr. Ladd, of Livermore Falls. Ladd swapped her with Leander Killbreth, of Hartford, and he sold her to Samuel Records, of Buckfield. Records sold her to G. M. Delaney, and Oct. 16, 1868, as Kate, at Narragansett Park, R. I., she won a race and a record of $2.31 \frac{1}{2}$, beating Climax. She was afterwards sold to F. J. Nodine, of Brooklyn, N. Y., and called "Belle of Brooklyn." June 4, 1869, at the Union Course, L. I., in a race for horses that never beat 2.31, she won the first and second heats in $2.31 \frac{3}{4}, 2.32 \frac{1}{2}$. She was finally put to breeding, and in 1872 she foaled black mare, Henrietta, by Nodine's Peacemaker.

\section{PELHAM.}

Bay gelding, under 15 hands high, foaled about 1837, formerly owned by Mr. B. Esmond, of Gardiner, Me., who purchased him about twenty-eight years ago, of Arnold Wentworth, who then lived on Sabattus Mountain. Pelham was then about seven years old, and a fast pacer. Nothing is known of his pedigree or early history. Esmond sold him to Oliver Walton, of Boston.

Walton sold him to Dennis McReady, of New York, and he was taken from Boston to New York in 1846. He was afterwards owned by Jacob Sommerindyke, and called Charlie Abel.

He was square-gaited as a trotter, after he changed his way of going, and very fast, and he was the first horse to 
trot in 2.28, in harness, which feat he performed at the Centreville Course, July 2, 1849, in a race against Lady Suffolk and Jack Rossiter, Pelham winning the third and fastest heat in 2.28, and the fourth in $2.29 \frac{1}{2}$, whereby he "rose into high notice." June 14, 1849, at Harlem, New York, in a race, two miles and repeat, he distanced Modesty in the first heat, winning the race, time, 5.16.

May 21, 1851, he trotted three-mile heats against Fanny and Selim, at the Centreville, winning in $8.05 \frac{1}{2}, 8.12$. May 26, at the same place, he beat Black Harry, Honest John and Selim, two mile heats in 5.15, 5.17.

May 23, 1850, at Boston, as Charlie Abel, he beat Jack Rossiter, two-mile heats, in 5.24, 5.16, 5.23. Jack Rossiter, winning the first heat.

\section{W. H. TAYLOR.}

Formerly called "Romeo" and "Winter Hill." Chestnut, or sorrel gelding, $15 \frac{3}{4}$ hands high, with four white stockings, and a stripe in the face, foaled in 1857, bred in Madison, Me., got by the Crawford horse (Norman), dam, by Witherell. Ash Savage bought him, when four years old, and sold him to C. C. Emery, of Skowhegan, and he was finally taken to Massachusetts, and afterwards to New York. Sept. 16, 1868, at Newburgh, N. Y., he beat Needle Gun, Old Put, Latham and Lady Whitman, in three straight heats, time, 2.35, 2.34, 2.34 $\frac{1}{4}$.

Sept. 30, at Troy, he beat Needle Gun, Old Put and six others, in straight heats, in $2.34 \frac{1}{2}, 2.32,2.33 \frac{1}{2}$.

The next day, Oct. 1, at the same place, he beat Old Put, Captain Gill and Surprise, winning again in three straight heats, time, 2.30, $2.30 \frac{1}{2}, 2.32 \frac{1}{2}$.

Oct. 14, same year, at Narragansett Park, R. I., he won 
a race against Duchess, Emperor, Western New York, Jack Lewis, Navigator, America, Topsey and Lady Walker. Duchess won the first heat, in $2.33 \frac{1}{4}$, Emperor the second, in 2.30, the third, in 2.32, and W. H. Taylor the fourth, fifth, sixth and race, in $2.33,2.29 \frac{1}{4}, 2.33$.

\section{YOUNG DEFIANCE.}

Stallion, foaled in 1869, owned by Wm. C. Howes, Newburgh, Me., got by Defiance, by Messenger Hunter, he by imported English Hunter, dam, Messenger, granddam, by Defiance, great, grand-dam, by thoroughbred Black Snake.

\section{KING'S PATCHEN.}

Black stallion, $15_{2}^{\frac{1}{2}}$ hands high, foaled in 1871, owned by I. D. King, West Gray, Me., got by Tom Patchen, dam, a Black Hawk mare.

\section{DASHA WAY.}

Bay gelding, foaled about 1857, in Litchfield, Me., got by Butterfield, by Old Eaton. He was taken to New York, and purchased there by a Maine man, and brought to Maine, after which he passed into the hands of $\mathrm{O}$. M. Shaw, of Bangor. Oct. 4, 1867, he trotted in Bangor, against Little Fred, and won in four heats, time $2.31 \frac{1}{2}$, $2.34 \frac{3}{4}, 2.36,2.33$, Fred winning the first and fastest heat.

At Boston, Oct. 17, 1866, he, in double team with Gen. McClellan, beat Ethan Allen and Honest Allen, in 2.39 $\frac{1}{4}$, $2.39 \frac{1}{2}$, mile and repeat.

\section{LEW PETTEE.}

Dark bay gelding, nearly 16 hands high, with great length, great bone, without clumsiness, and immense 
muscular development. He had a steep rump, like Mr. Bonner's Auburn horse, and resembled that horse in other particulars, foaled in 1860 , bred by Wentworth Thurston, Madison, Me., got by the Benson horse, he by Norman, dam, of Messenger descent. John Swan, of Anson, took him to New York, in 1866, and sold him to Mr. William Turnbull. Oct. 31, 1866, at the Union Course, L. I., in a race for a purse of $\$ 2000$, two miles and repeat, he distanced Bull Run, in the first heat, in $5.08 \frac{1}{2}$.

August 1, 1867, at Narragansett Park, he beat Lexington, winning the second, third and fourth heats and race, in $2.32 \frac{3}{4}, 2.45 \frac{1}{4}, 2.33 \frac{1}{2}$. Sept. 23 , at the Fashion Course, L. I., he again beat Bull Run, in straight heats, in 2.35, $2.38 \frac{1}{2}, 2.38 \frac{1}{2}$.

June 29, 1868, at the Fashion, he beat Dixie, winning the third, fourth and fifth heats and race, in 2.29, 2.32, 2.34. July 10, at the same place, he beat Tackey, in $2.30 \frac{3}{4}$, $2.33 \frac{1}{4}, 2.30 \frac{1}{4}$. July 16 he beat Old Put and Cora, at Narragansett, fastest heat 2.31, purchased in 1872, by F. D. Norris, Brooklyn, N. Y.

\section{READFIELD.}

Brown gelding, with star in forehead, and three white feet, about $15 \frac{1}{4}$ hands high, foaled in 1850 , bred by Isaiah York, of Weld, Me., got by the Potter horse, of Weld, he by a horse brought from the Provinces, said to be of English blood, and out of a mare by Old Winthrop Messənger, Readfield's dam, pedigree unknown.

York sold him to Robert Potter, of Weld, when four years old, and he sold him to Joseph Hutchins, of Readfield. He was afterwards sold to R. H. Libby, and taken to New York. 


\section{FARMER SIOCUM.}

Black gelding, with star in the forehead, 16 hands, $1 \frac{1}{2}$ inches high, foaled in 1864, bred by Simon Gray, of Woolwich, Me., got by a horse brought from New York, said to be of Abdallah blood, and his dam was by Homan's Messenger. IHe was worked in a jigger until he was seven years old, when he was purchased by John S. Heald, of Portland. He sold him to Warner \& Richardson, of Boston, and they to his present owner.

June 24, 1873, in a race at Boston, Farmer Slocum won the first heat in $2.37 \frac{3}{4}$, and the third in $2.34 \frac{1}{2}$, and was second in the race.

\section{LADY MORRIS.}

Brown mare, under 15 hands high, foaled in 1865 , bred by H. \& J. McKeen, of Stoneham, Me. Sold, when six years old, to Hezekiah Winslow, of Portland, and by him to Lon Morris, of Boston. In 1873, she obtained a record of 2.36 in a race. She is said to be a Brandywine.

\section{INK.}

Black mare, with faint star in forehead, 15 hands high, and weighs about 900 pounds, foaled in 1864, pedigree, unknown.

Purchased by Waldo T. Pierce, of Bangor, when four years old. At the Maine State Fair, in 1872, at Bangor, she won the 2.35 purse in three straight heats, in 2.37, $2.36,2.39$, trotting the first half-mile in the first heat in $1.15 \frac{1}{2}$, beating Phil. Sheridan, Gentle Annie and Mumm.

\section{PQMP.}

Gray gelding, $15 \frac{1}{2}$ high, and weighs about 1050 pounds, 
foaled in 1862, bred by Mark Leach, of Danville, Me., got by a gray stallion, called the Beatty horse, he by the Staples horse, of Topsham, dam, a bay mare, pedigree unknown.

Mrs E. Cornish, of Lewiston, sold Pomp, in 1872, to Isaiah Pompilly, of Auburn, and he was soon after sold to W. W. Smith, of Dixfield, Me. His speed was not thought much of at that time. Smith entered him in several races in the fall of 1872 . Oct. 10, at the Lewiston Driving Park, he won the three minute purse, beating a field of nine horses, his fastest record being 2.41. He was found to be an improving horse, and was entered in a race at the Forest City Park, the same season, which he won, distancing his competitors in the first heat.

\section{JOHN MURRAY.}

Dapple gray gelding, $15_{4}^{\frac{3}{4}}$ hands high, and weighs 1050 pounds, foaled in 1867, owned by William Murray, North Vassalboro, Me., got by Kentucky Boy, dam, of Messenger descent.

\section{PHIL. SHERIDAN.}

Brown gelding, with black points, 15 hands high, foaled in 1860, bred by Daniel Fawsett, of Windsor, Me., got by the Dr. Call horse (so called). He was brought to Maine from the Province of New Brunswick, by Shepherd Carey, of Houlton, and was said to be by thoroughbred Cannon Ball, dam, a Tam O'Shanter(?) mare. Dan. Hanscomb, of Hallowell, bought Phil. Sheridan, when three years old, and he was afterwards owned by Chas. Keen and Henry L. Taylor, of Portland, who sold him to D. H. Blanchard, of Boston. June 13, 1866, at Boston, 
in a race with Washington, Phil. Sheridan won the second heat in $2.35 \frac{1}{2}$.

\section{BOOTH.}

Brown gelding, with black points, 15 hands high, foaled in 1860, formerly owned by Daniel Fawsett, of Windsor, got by the Dr. Call horse, sire, of Phil. Sheridan. Dan. Hanscomb, of Hallowell, bought him, when four years old, and carried him to Massachusetts. Oct. 18, 1866, he won the sixth heat in a race at Boston, and a record of 2.35 .

\section{BLACK PRINCE (IAYES').}

Black gelding, foaled in 1865, bred in Maine, got by Hendrick Hudson, dam, of Messenger descent. Hendrick Hudson was by Roe's Abdallah Chief, out of a well bred mare, brought to Maine when five years old, and owned, about 1865, by Captain A. W. Calden, of Gardiner. Black Prince was owned in 1872 by S. Hayes, and June 29 , at Boston, he won a race in straight heats, beating Fanny Allston and Lady Morris, time $2.32 \frac{3}{4}, 2.36 \frac{1}{2}, 2.33 \frac{3}{4}$.

\section{WHIRLPOOL.}

Gray gelding, 16 hands high, foaled in 1867, bred by Moses Stacy, of Benton, Me., got by a gray horse, brought from the South during the war, and called Kentucky Boy. His pedigree is not known, but it was claimed, and his appearance indicated that he was well bred. The dam of Whirlpool was a good-sized gray mare, of Messenger descent.

Henry Green, of Fairfield, bought him, when two years old, for about $\$ 100$, and sold him, when he was four years 
old, to Messrs. Withee \& Gray, of Waterville, for $\$ 1500$. They sold him, a few months afterwards, to Boston parties, for $\$ 2,650$. He trotted in a race at Boston, in 1872 , when five years old.

\section{BUTTERFLY.}

Brown filly, with one white hind foot, foaled May 10, 1873, bred by James H. Lawrence, Somerset Mills, Me., got by Kentucky Boy, dam, by the Allen horse.

\section{LADY PILOT.}

Bay filly, with black points, two white hind feet, and star in forehead, foaled May 12, 1872, bred by F. D. Harmon, Gardiner, Me., got by Black Pilot, dam, an Indian Chief mare. Black Pilot was bred by R. A. Alexander, of Kentucky, and brought to Maine by Major J. T. Richards, of Gardiner.

\section{DRACO PRINCESS.}

Black mare, with no white, $15 \frac{3}{4}$ hands high, foaled June 26,1867 , bred by the late John L. Seavey, of Waterville, got by Draco, dam, by Hiram Drew. Mr. Seavey sold her, together with her dam, to C. Butman, Plymouth, Me., and he sold her, when three years old, to Abram Woodard, Esq., of Bangor.

\section{TROUBLESOME. .}

Chestnut gelding; with star in forehead, $15 \frac{3}{4}$ hands high, foaled in 1859, bred by William Penniman, of Readfield, Me., got by a Drew and Witherell horse, owned by Mr. Penniman, dam, a bay mare, by Old Eaton. Penniman sold him to W. Woodbury, of Norway, and he, 
when seven years old, to S. H. Jacobs, of Skowhegan, Me. August 17, 1871, at Bangor, Me., he beat Green Mountain Boy, winning the last three out of five heats

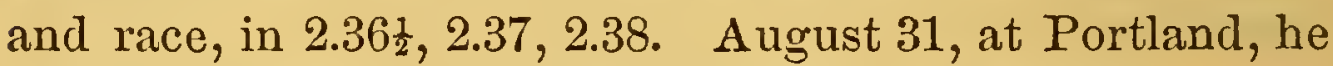
beat Carthage Boy and McClellan, in straight heats, in $2.38 \frac{1}{2}, 2.36 \frac{1}{2}, 2.37 \frac{1}{2}$.

\section{FANNY BRADBURY.}

Bay mare, with black points, foaled July 4,1854 , bred by Thos. C. Mulvey, Hollis Centre, Me., got by Blazing Star, dam, "Emmy," by Chellis horse, graud-dam, Miss Lowe, of unknown blood. Blazing Star was a horse of no breeding, and was neither speedy nor a getter of speed. The Chellis horse was sometimes called "Black Hawk," and was owned and kept by Capt. Jordan, of Saco.

Mr. Mulvey sold Fanny, when three years old, to Caleb Bradbury, and he, wlien five, to John N. Stimpson, of Alfred, Me., in whose hands she first commenced to trot.

July 4, 1861, at Scarborough, Me., she won a race

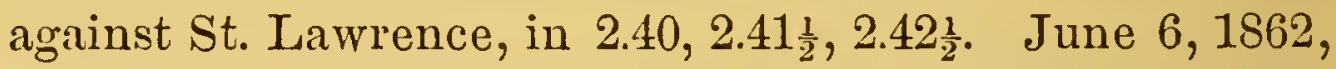
at Boston, she beat Rocky Mountain and Maud, in 2.37 $\frac{1}{4}$, $2.40, \dot{2} .39 \frac{3}{4}$.

\section{CHARCOAL.}

Black gelding, with white stripe in face, $15 \frac{1}{2}$ hands high, said to be by Gen. Knox. He was formerly owned by S. S. Ireland, of Dexter, Me., and sold by him to Waldo Pierce, of Bangor, Me. August 13, 1873, at Foxcroft, Me., he won a race, beating Ethan, in 2.44 $\frac{1}{4}, 2.46$, $2.45 \frac{1}{2}$.

\section{-GREEN MOUNTAIN MAID.}

Gray mare, $15_{\frac{3}{4}}^{3}$ hands high, foaled in 1863, bred-at 
least, formerly owned-by a Mr. Clark, of Bangor, Me., and called Milkmaid. We have been unable to trace her pedigree, but she is said to be of Messenger descent. Owned in Massachusetts, by Barney Rafferty. Sept. 23, 1873, at Concord, Mass., she beat Kate Gilbert, who won the first heat, Jenny Smith, Kangaroo, and Colonel R., time, $2.46 \frac{1}{2}, 2.51 \frac{1}{2}, 2.38 \frac{1}{2}, 2.38 \frac{3}{4}$.

\section{DAISY.}

Chestnut mare, foaled in 1855, supposed to be by Witherell. Taken to New York from Maine, and well known on the road in Brooklyn as Lady Wallace, and could trot in about 2.35. Purchased, in 1861, by Pickering Clark, and taken to Pittsfield, Mass.

\section{- YOUNG ETHAN ALLEN.}

Bay stallion, with black points, $16 \frac{3}{4}$ hands high, and weighs 1410 pounds, foaled in 1860, bred by Eliab L. Eaton, Manchester, Me., got by a son of Ethan Allen, dam, by the Beals horse, $2 \mathrm{~d}$ dam, by Stone's Messenger. Eaton sold him, and he was taken to New Hampshire, in 1871.

\section{JOSEPH R. CONANT.}

Blood bay stallion, with three white stockings, and stripe in face, $15 \frac{3}{4}$ hands high, and weighs 1000 pounds, foaled April 21, 1869 , bred by O. N. Blackington, then of Rockland, Me., got by Seth Warner, by Ethan Allen, dam, Sontag, Joseph R. Conant's dam, Lady Lang, by Telegraph, out of a Mambrino mare. Telegraph by Vermont Black Hawk, dam by Vermont Hambletonian. 


\section{T. R. ALLEN.}

Chestnut stallion, with no white marks, foaled in 1870, bred by Wright \& Norcross, Fearnaught Farm, Manchester, Me., got by Ethan Allen, dam, Tar River, thoroughbred.

\section{MAJOR CHISM.}

Bay colt, with four white feet, and star and snip in face, foaled July 12, 1871, owned by Geo. H. Bailey, Deering, Me., got by Ethan Allen, dam, a fast pacing mare, known in Boston as the Hayward mare, pedigree unknown.

\section{GEN. WARREN.}

Bay gelding, with black mane and tail, and four white feet, $15_{\frac{1}{2}}^{1}$ hands high, foaled in June, 1870 , bred by S. H. Hinds, Salem, Me., got by Ethan Allen, Jr., owned by A. B. Dolbier, Farmington, Me., said to be by Old Ethan Allen, Gen. Warren's dam, by Hogarth. Hinds sold him, when four months old, to A. B. Dolbier.

\section{EDGAR ALLEN.}

Chestnut colt, foaled May 3, 1873, bred by George F. Moore, North Anson, Me., got by Ethan Allen, Jr., dam, the Fitzgerald mare, by the Proctor horse, by Norman.

\section{PRINCESS.}

Black mare, foaled in 1869, owned by William Lawrence, Houlton, Maine, got by Cobbler, dam, not traced. Princess won the four-year-old purse, at the Maine State Fair, of 1873, at Bangor, fastest time, 2.50. 


\section{HORACE GREELEY.}

Blood bay, weighs 1000 pounds, foaled in 1869, bred by Nelson Herrin, Houlton, Me., got by a horse owned by Mr. Herrin, called the West horse, said to have trotted in 2.32, dam, of Horace Greeley, a Drew mare.

\section{GIPSEY.}

Gray mare, $15 \frac{3}{4}$ hands high, foaled May 23, 1867, bred by Nathan Stiles, Waterville, Me., got by Draco, dam, a gray pacing mare, brought from Massachusetts, and supposed to be of Messenger descent.

Stiles sold her, in 1872, to Wm. H. Thompson, of Wilmington, Delaware. In May, 1873, she trotted a trial at the Prospect Park, L. I., driven by J. H. Phillips, in $2.29 \frac{1}{2}$.

\section{CARLOTTA.}

Formerly "Belle of Augusta." Roan mare, with black points, $14 \frac{1}{2}$ hands high, foaled in 185-, bred by Rev. W. A. P. Dillinghrm, of Sidney, Me., got by Indian Chief, dam, by Witherell. Charles Milliken, of Augusta, bought her of Mr. Dillingham, and sold her to George M. Robinson, and he to George Means, for $\$ 1400$. As Belle of Augusta, she won the first and second heats in a race

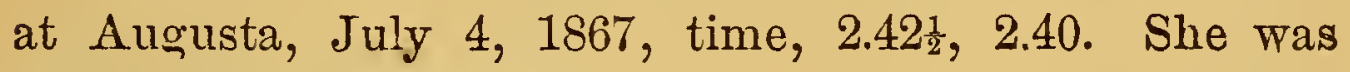
afterwards called Carlotta.

\section{BLACK TOPSEY.}

Black mare, under 15 hands high, foaled in 1855, bred in Kingfield, Me., got by Young Hogarth, and he by Hogarth, a horse brought from Nova Scotia, dam, of Black Topsey, by Old Eaton. Owned by J. C. Runkle, New York, and kept in Maine for breeding purposes. 


\section{DUCHESS OF LANCASTER.}

Dark brown filly, with white star in forehead, and two white hind feet, foaled Nov. 18, 1871, bred by John D'Arthenay, Augusta, Me., got by thoroughbred Lancaster, he by Lexington, out of Bonnets of Blue, by Imported Hedgeford, dam of Duchess of Lancaster, the Sanford mare, by Champion, $J r$, the sire of $\mathrm{Mr}$. Bonner's "Auburn horse."

\section{GRETTA.}

Brown filly, foaled April 27, 1872, bred by Gren. W. S. Tilton, Togus, Me., got by Lancaster, dam, Kate Eaton.

\section{QUEEN BESS.}

Chestnut filly, with one white hind foot, foaled March 28,1873 , bred by D. A. Coney, Augusta, Me., got by Lancaster, dam, of Messenger descent.

\section{XINGU.}

Brown colt, foaled in 1873 , bred by J. B. Watts, Thomaston, Me., got by Madockawando, dam, Fanny, the dam of Lucy Knox.

\section{QUEEN MAB.}

Gray mare, $15 \frac{1}{4}$ hands high, and weilghs 950 pounds, foaled in 1867, owned by William J. Haynes, Smithfield, Me., got by Doncello (of Morgan descent,) dam, by Allen horse, dam of Doncello, by Pishon horse.

\section{GENTLE KITTY.}

Chestnut filly, with star in forehead, and white on near hind foot, foaled June 13, 1871, owned by John C. Pills- 
bury, Palmyra, Me., got by English Ranger, dam, of Morgan descent.

\section{CHARLIE RANGER.}

Dark bay colt, with star in forehead, foaled in 1871, bred by G. B. Pillsbury, Unity, Me., got by Imported English Ranger, dam, by Dirigo.

\section{COMMODORE.}

Dark bay stallion, with black points, and star in forehead, foaled April 22, 1873, bred by B. R. Hunt, Unity, Me., got by English Ranger, dam of Messenger and Morgan descent.

\section{SHAGBARK.}

Dark bay filly, with black points, and star in the forehead, foaled in May, 1871, bred by B. R. Hunt, Unity, Me., got by English Ranger, dam, of Morgan and Messenger descent.

\section{HOULTON MAID.}

Bay filly, with black points, foaled May 24, 1872, owned by Harvey W. Leighton, Augusta, Me., got by Young Abdallah, owned by W. M. Lawrence, of Houlton, dam, by Imported Balrownie.

\section{ROVING LADY.}

Dark bay filly, with black points, foaled August, 1870, owned by C. A. Levanselles, Waldo, Me., got by Buchanan, dam, a fast trotting mare, known as the Searsport mare. 


\section{TROUBLESOME TRAPPER.}

Mahogany bay gelding, with star in forehead, and one white hind foot, $15 \frac{1}{4}$ hands high, foaled June 28, 1869, owned by J. H. Grant, North Vassalboro, Me., got by Troublesome, dam, thoroughbred and Morgan.

\section{MONOGRAM.}

Black stallion, $15 \frac{1}{4}$ hands high, and weighs about 900 pounds, foaled in 1868, the property of J. C. Runkle, of New York City, got by Mambrino Pilot, dam, Black Topsey, a small black mare, by Young Hogarth, taken to New York from Maine, and afterwards brought back. Monogram was foaled in Leeds, Me., at the farm of $\mathrm{Mr}$. C. L. Leadbetter, where his dam is kept for breeding purposes.

\section{MAMBRINO BISHOP.}

Mahogany bay stallion, with black points, and star in forehead, foaled June 22, 1871, bred by J. W. Vose, East Winthrop, Me., got by Monogram, dam, of English blood.

\section{FLIGHTY.}

Bay filly, foaled in 1870 , bred by L. R. Morrill, Gorham, Me., got by Taggart's Abdallah, dam, by Gen. Knox.

\section{PRINCESS DAGMAR.}

Bay filly, with stripe in face, foaled May 17, 1872, bred by Dr. Wright, Hampden, Me., got by Oysterman, Jr., dam, by O'Meara, $2 d$ dam, by Imported Albion, O'Meara by Imported Glencoe, out of Cotillon, by Imported Leviathan. Subsequently owned by Gen. W. S. Tilton, Togus, Me. 


\section{FLYING SQUIRREL.}

Gray colt, foaled May 9th, 1870, owned by F. Morrison, Clinton, Me., got by Gen. Putman, dam, of Messenger descent.

\section{LADY HUDSON.}

Bay mare, with black points, and one white hind foot, foaled in 1868, owned by E. W. Webb, Augusta, Me., got by Hendrick Hudson, dam, the Lanigan mare, of Gardiner.

\section{PAT. MALLOY.}

Black stallion, foaled May 25, 1871, owned by Charles B. Baker, Mercer, Me., got by Black Ranger, of the Eaton stock, dam, of Messenger descent.

\section{YOUNG DRACO.}

Black stallion, $15 \frac{3}{4}$ hands high, and weighs 1260 pounds, brèd by A. J. Hallett, Wèst Waterville, Me., got by Draco, by Young Morrill, dam, of Messenger descent. Subsequently purchased by C. Bickford, of West Waterville.

\section{DRACO CHIEF.}

Black stallion, $15 \frac{1}{4}$ hands high, and weighs 975 pounds, foaled in 1867, owned by J. D. Richardson, North Belgrade, Me., got by Draco, dam, by Red Cloud.

\section{LADY DRACO.}

Black filly, with star in forehead, foaled May 15, 1871, bred by $\mathrm{O}$. W. Tilton, West Waterville, Me., got by Draco Prince, by Draco, dam, of Morgan descent. 


\section{MAGGIE.}

Dark bay filly, foaled April 12, 1871, bred by W. P. \& H. N. A therton, Maple Grove Farm, got by Young Ajax, he by Smith's Ajax, dam, said to be of English blood.

\section{VICTOR HUGO.}

Bay colt, with three white feet, and star in forehead, foaled May 31, 1872, bred by W. P. \& H. N: Atherton, Maple Grove Farm, got by Young Ajax, dam (the dam of Maggie), of English blood.

\section{FRITZ.}

Dark brown colt, wich star in forehead, foaled May 8 , 1871, bred by W. M. Wright, Togus, Me., got by Romeo, dam, Topsey, by O'Meara, 2d dam, Lucy, by Imported Albion, Romeo by Charles Harris, by Imported Wagner.

\section{ATALANTA.}

Sorrel filly, with blaze in face, foaled May 26, 1872, got by Scythian, dam, Belle Winthrop. Owned by Charles R. Milliken and Gen. Wm. S. Tilton.

\section{I.ADY ADA DULETH.}

Red-grey mare, weight 1200 pounds, foaled in 1866, bred by Walton Withee, Anson, Me., got by the Brackett horse, afterwards called Butcher Boy, dam, of Morgan descent.

\section{STONY BROOK BELLE.}

Bright bay filly, with black mane and tail, foaled June, 1872, owned by H. H. King, Stony Brook Farm, Calais, Me., got by Woodbrook Messenger, of Houlton, dam, unknown. 


\section{BELLE TUFTS.}

Dark chestnut filly, with dapples, and no white marks, foaled June 10, 1871, bred by Samuel Bumpus, Paris, Me., got by Black Jack, a black stallion, once owned by Mr. Magner, the horse tamer, pedigree unknown, dam, by Imported Cobb's Brandywine. Owned by Joseph Tufts, Paris, Me.

\section{GENTLE FLORA.}

Sorrel filly, foaled April 20, 1872, owned by Adelbert Crockett, Stockton, Me., got by Young Buchanan, by Victor, dam, pedigree unknown.

\section{CLEOPATRA.}

Dark sorrel filly, with stripe in face, and one white hind foot, foaled June 8, 1871, owned by L. C. Davis, Vienna, Me., got by Gen. Dix (Fish's), by Patrick Henry, dam, of Messenger descent.

\section{KENTUCKY PRINCE.}

Bay colt, foaled May 6,1873, owned by Isaac A. Carr, East Winthrop, Me., got by Young Kentucky, owned by Wright \& Norcross, of Fearnaught Farm, Manchester, dam, Black Hawk mare, Jenny.

\section{JENNY LIND.}

Bay mare, foaled May 26, 1869, owned by F. R. Daggett, Sandy Point, Me., got by Highlander, dam, McLaughlin mare.

\section{BLACKBIRD (SAWYER'S).}

Black filly, with white star in forehead, spot on nose, 
and white hind foot, foaled July 9, 1872, owned by $\mathrm{E}$. Page Sawyer, West Gardiner, Me., got by the Otis horse, he by the Imported English horse, Black Negar, dam, pedigree unknown.

\section{PORTLAND.}

Bay colt, foaled May 10, 1872, bred by R. O. Conant, Portland. Me., got by Scythian, a thoroughbred colt, bred by Mr. Chenery, of Belmont, Mass., got by Trovatore, out of Vistula, by Imported Scythian, dam of Portland, by Rocky Mountain, 2d dam, a high bred mare from Canada. He was subsequently purchased by Gen. W. S. Tilton, Togus, Me.

\section{KENNEBEC KNOX.}

Black stallion, with star in forehead, spot on nose, and one white hind foot, foaled July 16,1871, owned by $\mathrm{H}$. W. Spaulding, Fairfield, Me., got by Gen. Knox, dam, a Morrill mare.

\section{BROWN DICK.}

Brown bay stallion, $15 \frac{1}{2}$ hands high, and weighs 1000 pounds, foaled June 2, 1865, owned by G. B. Leavette, Plymouth, Me., got by Gen. Knox, dam, by a Drew Horse.

\section{INDEPENDENCE (MERROW's).}

Stallion, 16 hands high, and weighs 1100 pounds, owned by Harford, Merrow \& Co., Hartland, Me., got by the Old Drew Horse, dam, by Morgan Black Hawk from Vermont. 


\section{BUTCHER BOY.}

Formerly called the "Brackett" horse, red roan stallion, bred by Mr. Brackett, of Starks, Me., got by a horse brought from Canada. He was afterwards owned by S. H. Jacobs, of Skowhegan, and trotted in 2.40 at Portland.

\section{FRANK.}

Chestnut gelding, with two white feet, 15 hands $2 \frac{1}{2}$ inches high, foaled in 1869, owned by G. \& E. Childs, Canton Point, Me., got by Matchless, dam, an Eaton mare.

\section{STATE OF MAINE.}

Gray gelding, $15 \frac{3}{4}$ hands high, foaled in 1869 , bred by John S. Lunt, Dixfield, Me., got by Young Brandywine, dam, by State of Maine.

\section{NELLIE MAYO.}

Bay mare, with black points, foaled July 10, 1873, bred by Frank M. Mayo, Canton, Me., got by Hampton, dam, brought from New York, and said to be by Royal George.

\section{HELEN.}

Bay mare, with black points, $15 \frac{1}{4}$ hands high, bred in Maine, and taken to Massachusetts, and owned by William Mason, of Taunton, got by the Hathaway Horse, he by the Pease Horse, by Winthrop Messenger, dam, of Helen, an English mare brought from the Provinces. Helen has a public record of 2.37, and is the dam of Bay Fearnaught, by Old Fearnaught. 


\section{APPENDIX.}

[The following is a list of stallions standing in the State of Maine, during the season of 1873 , not Maine bred, which have not been mentioned in this work-as taken from the records in the several counties.]

\section{SIR EDWIN.}

Dark mahogany bay stallion, with black points and no white marks, $16 \frac{1}{2}$ hands high, foaled Jume 1, 1867, bred by Edwin Thorne, Thorndale, N. Y., now owned by W. W. Chenery, Belmont, Mass. This stallion made the season of 1873 at the farm of W. B. Furguson, East Dixmont, Me. Pedigree :

By Hamlet, dam, Hope, by Hector, grand-dam, by Roebuck. Hector, by Lattourrett's Bellfounder, and he by imported Bellfounder, out of a mare of Messenger blood. Hamlet by Volunteer, dam, the Dr. Ostram mare, by Hulse's Hickory, he by Hickory, dam, by Mambrino, son of imported Messenger, grand-dam, by Bay Roman, and he by imported Roman. (Bay Roman was the sire of Katy Darling, the dam of Alexander's Abdallah,-the sire of Goldsmith Maid, Thorndale, etc.) Volunteer by Rysdyk's Hambletonian, dam, Lady. Patriot, by Young Patriot, grand-dam, the Lewis Hulse mare. Young Patriot by Patriot, dam, of Messenger Duroc, by Duroc, dam, by Messenger. Patriot by Blucher, he by Duroc, 
out of a full sister of American Eclipse, by Duroc, out of Miller's Damsel, by imported Messenger. Rysdyk's Hambletonian by Abdallah, he by Mambrino, and he by imported Messenger, dam, the Charles Kent mare, by imported Bellfounder, grand-dam, One Eye, by Bishop's Hambletonian, he by imported Messenger, dam, Pheasant, by imported Shark, grand-dam, by imported Medley.

\section{TOUCHSTONE.}

Chestnut colored stallion, $16 \frac{1}{4}$ hands high, and weighs over 1100 pounds, foaled April 22, 1864, bred and owned by Winthrop W. Chenery, Belmont, Mass. He made the season of 1873 at the farm of Albert N. Burrill, Newport, Me. Pedigree :

Sire, Imported Lapidist, dam, Meg Merrilies, by Leroy, he by Monmouth, he by John Richards, he by Sir Archy, and he by imported Diomed, out of imported Castianira, by Rockingham, grand-dam, by Black Snake, and he by Lee Buo (sire of Old Squaw, the dam of the slashing black trotting gelding, Lancet). Lapidist by Touchstone (winner of the St. Leger in 1834), out of Io, by Taurus. Taurus by Phantom, out of Katherine, by Soothsayer. Phantom by Walton, out of Julia, by Whiskey. Walton by Sir Peter, out of Arethusa, by Dungannon. Sir Peter by Highflyer, out of Papillon, by Snap. Highflyer by King Herod, out of Rachel, by Blank. King Herod by Tartar, out of Cypron, by Blaze. Tartar by Partner, out of Meliora, by Fox. Partner by Jigg, out of Sister to Mixbury, by Curwin's Bay Barb. Jigg by the Byerly Turk, out of Spanker, by the D'Arcy Yellow Turk, her dam by Lord Fairfax's Morocco Barb, out of Bald Peg, and she by an Arabian, out of a Barb Mare. Touchstone 
by Camel, out of Banter, by Master Henry. Camel by Whalebone (winner of the Derby in 1810), out of a mare by Selim. Whalebone by Waxy (winner of the Derby in 1793), out of Penelope, by Trumpator. Waxy by Pot$80^{\prime}$ 's, out of Maria, by Telemachus. Pot8o's by Eclipse, out of Sportsmistress, by Sportsman. Eclipse by Marske, out of Spiletta, by Regulus. Marske by Squirt, out of a mare by Blacklegs. Squirt by Bartlett's Childers, out of a mare by Snake. Bartlett's Childers by Darley's Arabian, out of Betty Leedes, by Careless-Spanker-Barb Mare.

\section{KINEO.}

Bay colt, with black points, three white feet and snip, foaled May 3, 1869, bred and owned by Winthrop W. Chenery, Belmont, Mass. Made the season of 1873 at the farm of H. C. Burleigh, Fairfield Centre, Me. Pedigree :

By Chenery's Gray Eagle, he by old Gray Eagle, he by Woodpecker, he by Bertrand, and he by Sir Archy, out of Eliza, by imported Bedford, grand-dam, imported Mambrino, by English Mambrino, sire of imported Messenger. Dam, of Kineo, Molly Taylor, by thoroughbred Prince Albert, out of Mary Taylor, by thoroughbred Bolivar, grand-dam, by Abdallah, by Mambrino, and he by imported Messenger, out of Amazonia, by a son of imported Messenger. Prince Albert, by imported Emigrant, out of Nun, by Sir Henry, by Sir Archy, dam, by imported Diomed, grand-dam, by American Eclipse, by Duroc, out of Miller's Damsel, by imported Messenger.

Katahdin, an own brother to Kineo, was purchased, in 1873, by C. Butman, Plymouth, Me. 


\section{SCYTHIAN.}

Bright bay stallion, with black points, $15 \frac{3}{4}$ hands high, foaled May 3, 1866, bred and owned by. Winthrop W. Chenery, Belmont, Mass. Made the season of 1873 at the farm of Robert Houston, Falmouth, Me., three miles from Portland. Pedigree :

Got by Trovatore, by imported Monarch, out of Madonna, by imported Yorkshire, grand-dam Magnolia (dam of Kentucky), by imported Glencoe. 1st dam, Vistula, by Imported Scythian, 2d dam, Vandal's dam, by Imported Tranby, 3d dam, Lucilla, by Trumpeter, 4th dam, Lucy, by Orphan, 5th dam, Lady Gray, by Robin Gray, 6th dam, Maria; by Melzar, 7th dam, by Imported Highflyer, Sth dam, by Imported Fearnaught, 9th dam, by Ariel, 10th dam, by Imported Jack of Diamonds, 11th dam, by Imported Mare Diamond.

\section{MADOCKAWANDO.}

Gray stallion, over 15 hands high, foaled in June, 1869, bred in New Brunswick, by H. N. Perrigo. Made the season of 1873 at the stable of J. B. Watts, Thomaston, Me. Pedigree : Got by the thoroughbred horse, Aracan, dam, by the Garrack horse, grand-dam, by Yankee Grey, out of a thoroughbred mare. Aracan was bred in England, by Lord Exeter, foaled in 1860, got by Ambrose, dam, Ava, by Lanercost, grand-dam, Mecca, by Sultan, great, grand-dam, Miss Cantley, by Stamford. Ambrose, by Touchstone, out of Annette. Touchstone, by Camel, out of Banter, by Master Henry. Lanercost was by Liverpool, out of Otis, by Bustard. Sultan was by Selim, out of Bacchante, by Williamson's Ditto. Selim's dam by Alexander, son of Eclipse. The dam of 
Williamson's Ditto was Arethusa, by Dunganon, son of Eclipse. The dam of Bacchante was by Mercury, son of Eclipse, out of a daughter of King Herod, and the mare Folly, by Marsk, sire of Eclipse.

\section{SULTAN.}

Light chestnut thoroughbred stallion, foaled in 1870 , bred by Geo. T. Allman, Cornersville, Tennessee. Owned by Gen. Wm. S. Tilton, Togus, Me., got by Watson, he by Lexington, out of Ann Watson, by Imported Glencoe. 1st dam, Sultana, her sire by Imported Glencoe, out of Giantess, by Imported Leviathan, hence full brother to Peytona, 2d dam; by Imported Albion, 3d dam, by Wagner, 4th dam, Cora (sister to Medoc), by American Eclipse, 5th dam, Young Maid of the Oaks, by Imported Expedition, 6th dam, Maid of the Oaks, by Imported Spread Eagle, 7th dam, Annette, by Imported Shark, etc. For extended pedigree see Bruce's Stud Book, Vol. II.

\section{I.ANCASTER.}

Thoroughbred bay stallion, with black points, $15 \frac{3}{4}$ hands high, and weighs 1030 pounds, foaled in 1863, bred by R. A. Alexander, Woodford county, Kentucky, owned in 1873, and for several years by Allen Lambard, Esq., Augusta, Me., got by Lexington, dam, Blue Bonnet, by Imported Hedgeford, 2d dam, Gray Fanny, by Bertrand, 3d dam, by Imported Brainard, 4th dam, Arminda, by Imported Meảley, 5th dam, by.Bolton, 6th dam, Sally Wright, by Orrick. For extended pedigree see Bruce's Stud Book.

At the fall meeting of the Laclede Course, Oct. 8, 1866, in the race for three-year-olds, Lancaster, Stonewall 
Jackson, Muggins and Copper ran. Lancaster was an

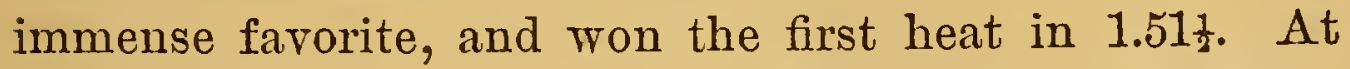
Cincinnati, in Oct., 1866, he won the Buckeye stakes in two heats. Dec. 26, following, at the Metairie Course, New Orleans, he won a two-mile race, for all ages in two heats, time, $3.46 \frac{1}{4}, 3.46 \frac{1}{4}$, winning with ease. He is own brother to Thunder, and Lightning, and is said, by the Spirit of the Times, to be the "best of that famous band of brothers, the cock chickens of the Old Blue Hen, Blue Bonnet, by Hedgeford." In 1868 he won the Saratoga cup.

\section{SHERROD.}

Thoroughbred chestnut stallion, 15 hands, $1 \frac{1}{2}$ inches high, and weighs over 1000 pounds, foaled in 1857, bred by J. A. Grinstead, of Lexington, Kentucky, and brought to Maine in 1873 , by Henry E. Fitz, of Auburn, got by Lecompte, by Boston, who will be remembered as the stubborn competitor of Lexington, dam, the celebrated mare, Picayune, by Medoc. For extended pedigree see Bruce's Stud Book.

Sherrod was a first-class race horse, and is said to have run a single mile in 1.46 , two miles in $3.38 \frac{3}{4}$, as a threeyear old, and a third heat of three miles in $5.28 \frac{3}{4}$.

\section{CADMUS.}

Thoroughbred stallion, foaled in 1864, bred by Daniel McMillan, Xenia, Greene county, Ohio, and owned by Means \& Butler, Augusta, Me., got by Ben. Butler (recorded Scribler), he by Imported Scythian, out of Emma Wright, by Imported Margrave. Margrave by Muley, dam, Election, etc. Scythian by Orlando, out of Scythia, 
by Hetman Platoff. Orlando by Touchstone, etc. The dam of Cadmus was by Ohio Cadmus, he by American Eclipse, out of Di. Vernon, by Imported Florizel, etc., etc.

\section{YOUNG SKY LARK.}

Dark bay stallion, with black points, and two white hind feet, $16 \frac{1}{2}$ hands high, and weighs 1200 pounds, foaled in 1866, bred by Mr. Hoffman, of Franklin county, Pa., got by the thoroughbred imported horse; Sky Lark(?), dam, by Cassius M. Clay, he by Henry Clay, etc., etc. Mr. Hoffman sold Young Sky Lark in 1872, and he was brought to Maine, and is owned by Ceylon Rowe, W. W. Bartlett, and St. John Hastings, Bethel, Me.

\section{BLACK PILOT.}

Black stallion, with white hind feet, $15 \frac{3}{4}$ hands high, and weighs 1020 pounds, foaled May 8, 1868, bred by R. A. Alexander, Woodburn Farm, Woodford county, Kentucky, and brought to Maine by Major J. T. Richards, of Gardiner, got by Roscoe, by Pilot, Jr., out of Native American's dam, 1st dam, Eugene, by Swigert's Lexington, he by Lexington, out of the famous race mare, Ann Innis, by American Eclipse, 2d dam, by Brawner's Eclipse, he by American Eclipse, 3d dam, by Medoc, he by American Eclipse, 4th dam, Mary Streshley, by John Henry, he by Aratus, 5th dam, Mary Hunter, by Harris' Paragon, 6th dam, by Imported Buzzard, 7th dam, by Wade Hampton's Paragon, etc., etc. For extended pedigree see Wallace's Stud Book.

\section{KENTUCKY BOY.}

Dark gray stallion, about 16 hands high, and wcighs 
1100 pounds, brought from the South during the war, and shows good breeding. He has been owned by R. S. Doe, of Burnham, Collins Eaton, of Fairfield, and now by H. A. Noble, Pittsfield. He is said to be by Lexington, dam, by Gray Eagle.

[The above pedigree we consider very unreliable, although the horse shows breeding, and has sired several quite speedy colts.J. W. T.]

\section{BEACON.}

Bay stallion, $15 \frac{1}{2}$ hands high, foaled in 1865 , bred by Edwin Thorne, Thorndale, N. Y., got by Volunteer, by Rysdyk's Hambletonian, dam, Faith, by a son of American Star, out of a Long Island Black Hawk mare, granddam, a trotting mare of unknown pedigree. Sold to William H. Scott, Boston, Mass. Owned in 1873 by Messrs. Wright \& Norcross, Manchester, Me.

\section{YOUNG ETHAN.}

Mahogany bay stallion, with black points, $15 \frac{1}{2}$ hands high, and weighs 1000 pounds, foaled June 14, 1863, bred in Mass., by P. H. Walker, got by Ethan Allen, dam, by Imported Hunter(?), grand-dam, of Messenger descent. Owned by A. S. Pease, Gardiner, Me.

\section{GRAY FEARNAUGHT.}

Dark iron gray stallion, $15 \frac{3}{4}$ hands high, and weighs 1000 pounds, foaled in 1868, July 16, bred in St. Albans, Vt., got by Old Fearnaught, dam a gray mare, of Messenger descent. Owned by J. S. Haynes, Norridgewock, Me. 


\section{ABDALLAH.}

Bay stallion, about 15 hands high, foaled in 1861, bred by David M. Taggartt, Goffstown, N.H., got by Farmer's Beauty, by Gifford Morgan, dam, by Old Abdallah, granddam, by Imported Trustee, being full brother to Taggart's Abdallah(?) He was owned from 1868 to 1872 by P. M. Jefferds, Foxcroft, Me., and since by Nelson Herrin, Houlton, Aroostook county. He has a public record of 2.38 in a race.

[We believe this to be the horse called Isaac Woodruff, in Wallace's Vol. II, page 251.-J. w. T.]

\section{AJAX.}

Dark bay stallion, $15 \frac{3}{4}$ hands high, foaled in 1865 , bred in Dover, N. H., got by Smith's Ajax, sire of Jesse Wales, dam, by Perkins' St. Lawrence, grand-dam, Morgan. Brought to Augusta, Me., in May, 1870, by George M. Robinson. For extended pedigree of Smith's Ajax see Wallace's 'Trotting Register, Vol. II, page 97.

\section{GIDEON.}

Dapple gray stallion, with black points, 15 hands $2 \frac{1}{2}$ inches high, and weighs 1080 pounds, foaled in 1860, bred by A. Goldsmith, Orange county, New York, got by Rysdyk's Hambletonian, dam, by Young Engineer, he by Engineer by Imported Messenger, grand-dam, by Commander, he by Commander, by Imported Messenger. Brought to Maine by Col. T.S. Lang, and sold to F. S. Palmer, Bangor, Me.

\section{YOUNG DRACO PRINCE.}

Black stallion, foaled in 1870 , bred by John M. Saw- 
telle, of Fitchburg, Mass, got by Draco Prince, dam, Messenger and thoroughbred. Owned in 1873, by Asia Jones, Springfield, Me.

\section{ETHAN ALLEN, JR. (HOLLAND's).}

Blood bay stallion, $14 \frac{3}{4}$ hands high, and weighs 942 pounds, foaled in 1860, got by Ethan Allen, dam, by Cock of the Rock. Owned by J. W. Holland, York county, Me.

\section{JOHNNY MORRILL.}

Recorded in Wallace's Trotting Register as Morrill Prince, dark brown stallion, 15 hands high, and weighs 950 pounds, foaled in 1860 , bred in New Hampshire, and owned by J. M. Davis, Cornish, Me., got by Perkins' Young Morrill, of Mass., dam, by Flint Morgan. Johnny Morrill is the sire of Mumm and Belle Gibbs.

\section{ETHAN ALLEN JR. (DOLBIER's),}

Bay stallion, with black mane and tail, white spot on nose, and three white feet, foaled in 1863. Owned by $A$. E. \& A. B. Dolbier, Farmington, Me., got by Ethan Allen, dam's pedigree unknown.

\section{SAMBO.}

Black stallion, 16 hands high, and weighs 1160 pounds, foaled about 1860, bred in England, and purchased for the Royal Agricuitural Society, of Prince Edward's Island, by Earl of Zetland, got by Gourikah, out of Matchless, by St. Martin, her dam, Lady Eden, by Partizen. Owned by Joseph Pearce, Houlton, Me. 


\section{ORLAND BOY.}

Dapple gray stallion, foaled in 1864, brought from the Provinces when three years old, formerly owned by Jas. McRenney, of Orland, Oliver Harriman, of Brewer, and in 1873 by Geo. C. Emerson, Ellsworth, Me.

\section{YOUNG RULER.}

Stallion, owned by D. \& Z. Weaver, Ellsworth, Me., bred in New Brunswick, Meramichi, got by a Clydesdale horse, dam, Columbus and French Gray.

\section{SCOTCH MORGAN.}

Dark brown stallion, with black mane and tail, two white hind feet, and white stripe in the face, weighing 1200 pounds, foaled in 1863, brought from Nova Scotia to New Brunswick, and from New Brunswick to Calais, Me., got by a horse imported from Scotland to Nova Scotia, dam, of Morgan descent. Owned by Evan Powell, Jr., Topsfield, Me.

\section{MORRILL PRINCE (HERSEY'S).}

Dark bay stallion, with black points, weighing 975 pounds, foaled in 1866. Owned in Penobscot county, by Thomas Hersey, got by Young Morrill.

\section{DUKE OF YORK.}

Blood bay stallion, with black points, and weighs 1200 pounds, foaled in 1866, bred by Elijah Dickinson, County of York, New Brunswick, got by the Montgomery horse, by Imported Champion, dam, by John O. Gaunt. Owned by Andrew Jamison, Springfield, Me. 


\section{ROB ROY (D'ARTHENAY's).}

Bay stallion, with star in forehead, and two white hind feet, owned by John D'Arthenay, Augusta; Me., got by Live Oak, owned in. Canada.

\section{HAVELOCK.}

Dark bay stallion, 16 hands high, and weighs 1242 pounds, foaled in 1866. Owned by Charles F. Bessey, Albion, Me. He was purchased in the Provinces, and was said to be.got by a Clydesdale horse, dam, half Clydesdale and half Nigger(?).

\section{GREY LION.}

Dapple gray stallion, weighs 1260 pounds, foaled in 1859 , bred in Woodstock, N. B., owned by William Jepson, Vassalboro', Me., got by an imported Clydesdale horse, dam, a French mare.

\section{BRITISH HUNTER.}

Black stallion, $15 \frac{1}{2}$ hands high, and weighs 1130 pounds, foaled in 1860, bred in the Province of New Brunswick, and brought to Maine by David L. Hunter, Clinton, Me., got by a descendant of the Vermont Black Hawk, dam, an English mare. Owned by F. P. Furber, Clinton, Me.

\section{ST. LAWRENCE.}

Chestnut stallion, 15 hands high, and weighs 900 pounds, foaled in 1861, bred in Canada, owned by Frank Rideout, Monmouth, Me., pedigree unknown. 


\section{PRINCE.}

Bay stallion, with black points, 15 hands high, and weighs 1140 pounds, foaled in 1864, owned by James Luce, Kingsbury, Me. Brought from Prince Edward's Island.

\section{COLUMBUS.}

Gray stallion, 16 hands high, and weighs 1450 pounds, foaled in 1856, bred by John Nickerson, on Prince Edward's Island, and brought to Maine by M. H. Strickland \& Co., of Bangor, got by the imported stallion, Columbus(?), dam, said to be a Clydesdale mare.

\section{WOODSTOCK BOY.}

Roan gray stallion, with black points, $15 \frac{1}{2}$ hands high, and weighs 1200 pounds, foaled in 1865, brought from the Province of New Brunswick, and sold to William Downs, of Sebec. Said to have been got by an imported stallion, dan, a Morgan mare.

\section{BLACK PRINCE (BARTLETT'S).}

Black stallion, with two white hind feet, 15 hands high, and weighs 950 pounds, foaled in June, 1869, bred by Thomas Eastman, West Milan, N. H., got by Groveton Chief, of N. H., dam, a Canadian French mare. Owned by C. P. \& S. Bartlett, Hanover, Oxford county, Me.

\section{MESSENGER HUN'TER.}

Black stallion, with no white marks, $15 \frac{1}{4}$ hands high, and weighed 1000 pounds, foaled in 185-, bred in Massachusetts, and brought to Maine by E. L. Norcross, got 
by imported English Hunter, a four mile racer, dam a Messenger mare. Owned by J. W. Thompson, Hartford, Me., and Milton French, of Turner. Died at Canton, June 24, 1874.

\section{GREEN MOUNTAIN MORRILL.}

Bay stallion, $15 \frac{1}{2}$ hands high, and weighs 1000 pounds, foaled in 1858, bred by a Mr. Burnside, of Lancaster, N. $\mathrm{H}$., got by the Old Morrill horse, of Danville, Vt. Owned by H. E. Hutchins, Andover, Me.

\section{YOUNG GIFFORD MORGAN.}

Black stallion, $16 \frac{1}{4}$ hands high, and weighs 1125 pounds, foaled in 1869; owned by F. M. Atherton, Waterford, Me., got by Old Gifford Morgan, he by the Walker horse, he by Woodbury, he by Justin Morgan, dam of Young Gifford, by thoroughbred Black Snake(?).

[The pedigree, as found in the Registry of Deeds, is Woodbury, by Green Mountain Boy, he by Justin Morgan. We give the pedigree of Woodbury as given by Linsley. We are unable to find in Linsley's work a Gifford Morgan corresponding with the above.-J. W. T.]

\section{RED OAK, JR.}

Chestnut stallion, 16 hands high, and weighs 1100 pounds, foaled June 11, 1868, bred by Zachariah Stanley, Union County, Indiana, got by Bennett's Red Oak, by Iron's Cadmus, he by Cadmus, by American Eclipse. (For extended pedigree see Bruce's American Stud Book.) Dam, of Red Oak, Jr., was got by Champion, grand-dam, by Kirkland. Owned in Norway, Me.; by E. S. Crockett. 


\section{YOUNG ST. LAWRENCE.}

Dark brown stallion, $15^{\frac{1}{2}}$ hands high, and weighs 1200 pounds, foaled in 1853 , bred by a Mr. Bains, in Canada, got by St. Lawrence, dam, an English blood mare.

Made the season of 1873 in Sumner, Oxford, County, Me. Owned by Daniel Percival, Compton, N. H.

\section{LIVE OAK.}

Red roan stallion, $15 \frac{1}{4}$ hands high, and weighs 1050 pounds, foaled in 1862, bred in Canada West, got by Old Live Oak, dam, by St. Lawrence. Owned by Crooker \& Thayer, Norway, Me.

\section{BLACK JACK.}

Black stallion, 16 hands high, and weighs 1100 pounds, foaled in 1860, bred in Skowhegan, Me., got by Old Eaton, dam, of Black Hawk blood. Owned by J. E. Bessey, Hebron, Me.

[NoтE.-The above description and pedigree is taken from the records of stallions in the Oxford county Registry of Deeds, and we consider it unreliable for the following reasons, viz. : the Old Eaton horse was taken to Nashville, Tenn., in 1857. The abovenamed horse was formerly owned by Mr. Magner, the horse tamer, and it has been said that he came from Canada.-J. w. T.]

\section{PRINCE EDWARD.}

Black stallion, weighing 1200 pounds, foaled in 1S61, imported from Prince Edward's Island, by Eli West, of Belfast, Me., sire, imported from Scotland, by Government of Prince Edward's Island, dam, English, thoroughbred. Owned by B. F. Coburn, South Molunkus, Me. 
FRANK PIERCE.

Stallion, orwed by D. E. Lucy, Houlton, Me., got by St. Lawrence Chief, he by St. Lawrence, dam, of St. Lawrence Chief, thoroughbred, dam of Frank Pierce, by Billy Root, by Sherman.

\section{LION.}

Black stallion with white star in forehead, stripe on nose, and white hind feet, $15 \frac{3}{4}$ hands high, and weighs 1250 pounds, foaled in 1865, brought from New Brunswick, by Jarvis Hayward, of Portage Lake, got by an imported Clydesdale, dam, Warrior and Morgan. Owned by F. D. Walker, Dalton, Me.

\section{BLACK CLYDE.}

Black stallion, weighing 1300 pounds, foaled in 1867, bred by Daniel McDonald, East River, Pictou, N. S., imported into Me. in 1S72, by Wm. McDonald, Crystal Plantation, Aroostook county, Me., got by an imported Clyde, from Scotland.

\section{BILL.}

Iron gray stallion, weighing 1110 pounds, foaled about 1863, bred on Prince Edward's Island, got by a Clydesdale horse, further pedigree unknown. Orned by James T. Dakin, Amity, Me.

\section{WEST HORSE.}

Bay stallion, weighing about 950 pounds, foaled ahout 1853, owned by Nelson Herrin, Houlton, Me., got by Morgan Cæsar, by Gifford Morgan, by Woodbury, etc., etc. 


\section{BLACK DONALD (FIELD'S).}

Black stallion, $15 \frac{1}{2}$ hands high, and weighs 1100 pounds, foaled in 1863, bred in Canada, and bought, in May, 1859, in Montreal, and brought to Maine by Edward Carlton, of Woolwich. Owned by Wm. H. Field, Bath, Me., pedigree unknown.

\section{NORTON'S HAMBLETONIAN.}

Mahogany bay stallion, $15 \frac{1}{2}$ hands high, foaled August 22, 1870, bred by Horace Williams, Centreville, N. Y., got by Williams' Hambletonian, he by Rysdyk's Hambletonian, dam, by Biggot's Rattler. Owned by J. P. Norton, Lewiston, Me.

\section{FLEETFOOT (NORTON's).}

Bay stallion, 15 hands, $2 \frac{1}{2}$ inches high, foaled in 1867, bred by George A. Atkins, Lincoln, Vt, got by Col. Phyfe, he by Columbus, dam, by Normour, grand-dam, by Old Morrill. Owned by J. P. Norton, Lewiston, Me.

\section{ENGLISIT RANGER.}

Blood bay stallion, with black points, $16 \frac{1}{2}$ hands high, and weighs 1250 pounds, foaled in 1861. Imported from England, by Mr. McMunnigan, of Frederickton, N. B. Owned by George B. Pillsbury, Unity, Me.

\section{MORRILL CHIEF.}

Dark chestnut stallion, with black points, 16 hands high, and weighs 1100 pounds, foaled in 1865, brought from Vermont, when two years old, by D. E. Lucy, of Houlton, Me, got by Young Morrill, dam, by Napoleon, 
he by Flint Morgan, etc. Owned by E. W. Seavey, North Searsport, Me.

\section{CHAMPION BLACK HAWK.}

Black stallion, 15 hands high, got by the Rix horse, he by Vermont Black Hawk, dam, by Parks horse, he by Vermont Morgan Champion, he by Sherman, by Justin Morgan, bred in Vermont, and brought to Maine, and owned by Wm. Beals, of Winthrop. Beal sold him to O. T. Bosworth, of Canton, and he, in 1866, to Samuel Records, of Buckfield. He was the sire of Kate Gilbert.

\section{HENRY CLAY.}

Black stallion, $15 \frac{3}{4}$ hands high, and weighs 1100 pounds, got by Dr. Dean's Black Hawk, of Greenfield, Mass., dam of Messenger descent, Dr. Dean's Black Hawk by Vermont Black Hawk. Owned by Henry W. Humphrey, Turner, Me.

\section{YOUNG CHAMPION.}

Dark bay stallion, with black points, 16 hands high, and weighs about 1250 pounds, foaled in 1865, bred in the Province of New Brunswick, got by Old Champion, dam, of Morgan descent. Owned by F. O. Goodwin, in Penobscot county, Me.

\section{KING HEROD (SOULE'S).}

Dark bay stallion, 16 hands high, weighing 1100 pounds, foaled in June, 1868, bred in St. John, N. B., got by the thoroughbred stallion, Southerner, dam, Queen Isabel, by Cannon Ball. Owned by Pomroy C. Soule, Freeport, Me. 


\section{JOHN.}

Black stallion, 16 hands high, and weighs 960 pounds, foaled in 1861, bred in Virginia, and brought to Maine, when three years old, by Capt. James W. Potter. In 1873 kept in Harrison, Me., by C. C. W. Sampson.

\section{VICTOR.}

Dark steel-colored stallion, 15 hands high, and weighs 1050 pounds, foaled May 10, 1868, got by Green Mountain Morgan, he by Old Gifford Morgan, dam, of Messenger descent. Made the season of 1873 at $\mathrm{H}$. C. Boothby's, South Waterboro', Me.

\section{FARMER'S FAVORITE.}

Black stallion, $15 \frac{1}{2}$ hands high, and weighs 1125 pounds, bred in Vermont, age unknown, got by the Brownington Black Hawk, he by Vermont Black Hawk, dam, of Molgan descent. Owned by Chas. Holland, Limerick, Me.

\section{CALEDONTA.}

Dark bay stallion, with black points, $16 \frac{1}{4}$ hands high, and weighs 1200 pounds, foaled in 1860, bred in Burke, Vt., got by the Pix horse, he by Black Hawk, dam, by the Bridgham horse, by Billy Root. Stood, in 1873, in Cornish Village, York county, Me., in care of Isaac Small.

\section{BLACK HAWK PLATO.}

Black stallion, with no white marks, $15_{4}^{\frac{3}{4}}$ hands high, and weighs 1125 pounds, foaled May 4, 1859, bred by Frank IIall \& Brother, Bridgeport, Vt., got by Plato, by 
Vermont Black Hawk, dam, of Plato, by Sir Charles, by Duroc, by Imported Diomed, Black ITawk Plato's dam, by Vermont Black Hawk, her dam, by Sir Charles, etc.

Black Hawk Plato was subsequently purchased by MLr. D. E. Lucy, of IIoulton, Me., where he stands for service, and is called, by good judges, one of the finest stallions in the State.

\section{SHERMAN ISNOX.}

Black stallion, $15 \frac{1}{2}$ hands high, foaled in 1861 , formerly owned by David Averill, Westbrook, Me., got by Sherman Black Hawk, dam, the Bartol mare, by the Merrow horse. He was purchased, in 1871, by Messis. Holbrook \& Terrssbury, and taken to the Highland Farm, Oxford, Mie.

\section{PAUL CLIFFORD.}

Black stallion, with two white heels behind, foaled in 1860, owned by Moses N. Stanley, Porter, Me., got by Sherman Black Hark. Has no public record, but is said to have trotted in private in 2.30 .

The following extract from the Public Laws of the State of Maine, passed by the fifty-second Legislature, A. D. 1873 , we publish for the benefit of all parties concerned: 


\section{EXTRACT FROM PUBLIC LAWS.}

\section{CHAPTER 135.}

AN ACT for the better preservation of horse records.

Be it enacted, etc., as follows :

SECT. 1. Any person or persons owning or keeping a stallion for breeding purposes, shall be required before advertising, by written or printed notices, the services of said stallion, to file a certificate with the register of deeds in the county where said stallion is owned or kept, stating name, color, age, size, together with the pedigree of said stallion as full as attainable, and the name of the person by whom said stallion was bred; and it shall be the duty of the register to record such certificate in a book kept for that purpose, properly indexed, upon receipt of a fee of fifty cents for each certificate of not more than one page, and a further sum of twenty-five cents for each additional page.

SEcr. 2. Any person who shall neglect to make and file the certificate required by the provisions of this act shall not recover any compensation for tho services named in section one, and if he shall knowingly and willfully make and file a false certificate of the statements aforesaid, shall forfeit the sum of one hundred dollars, to be recovered by complaint, indictment, or action of debt in any court of competent jurisdiction; and all penalties recovered shall be for the use of the county where the offence is committed.

SECT. 3. This act shall take effect when approved.

[Approved February 26, 1873.]

\section{ERRATA.}

On page 40,4 th line from the top, the figures $59,35 \frac{1}{2}$ should read $59.35 \frac{1}{2}$.

On page 88 , Mineada slould read Mineola.

On page 128, in the sketch of Gilbreth Knox, ith line, the figures $\$ 1700$ should be $\$ 17,000$. 


\section{INDEX.}

Abdallall................. 306 Admiral Dot............. 228 Air..................... 180

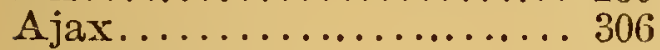
Allen Horse........... 30 All Trumps............ 84 Amazon................ 263 American Knox.......... 146 Andrew Johnson......... 203 Androscoggin Boy........ 208 Androscoggin Knox....... 170 Andy Patchen........... 231 Ann................... 237 Anson Belle............. 207 Arbutus............... 173 Aroostook Boy........... 72 Aroostook Knox......... 143 Atalanta................ 294 Anburn Boy........... 56 Angusta............... 211 Avery Holse............ 257

Baby Boy............. 217 Badger................... 66 Baffler................ 253 Baker Boy............. 47 Ballard................ 221

Bangor................ 79

Barney................. 146

Barney Kelley........... 218

Baron................. 252

Bartlett's Knox .... ..... 147

Batchelder Horse........ . 71

Bayard................ 80

Bay Beauty............. 90

Bay Beauty............. 252

Bay Dick.............. 59

Bay Harry.............. 201

Bay Whalebone..........276

Beacon................... 305

Beals' Horse.............. 91

Beau Hickman. ......... 193

Beauregard............. 45

Becky Sharp............ 177

Bedrock................. 191

Belle Barbour............. 191

Belle Gibbs.............. 220

Belle Gilbreth............ 189

Belle Hight. ............. 176

Belle Knox (Jacob's)..... 176

Belle Knox (Hanscomb's). . 190
Belle IKnoxall........... 177

Belle of Brooklyn........ 277

Belle of Portland.......... 42

Belle Patchen............. 232

Belle Strickland.......... 43

Belle Tufts............... 295

Bellfluker............... 238

Bell Morrill. . . . . . . . . . . 225

Bell Munson.............. 196

Bellona................ 252

Belmont................ 247

Bendigo............... 194

Ben. Hampton. . . . . . . . . 159

Ben. Norrill. . . . . . ...... 212

Benicia Boy............. 232

Bennett Horse........... 92

Benseeboo............... 251

Benson Horse. .......... 116

Benson Horse. . ........ 258

Bertram............... 252

Bessie Knox.............. 193

Betsey Trotwood........ 222

Beulah................ 85

Big Feamanght. . . . . . . . . 244

Bill................... 313

Bill Baker.............. 66

Billy Bumpus. ........... 261

Billy Mlorgan............. 215

Billy Mountfort. . . . . . . . . 159

Billy Patchen........... 234

Birdcatcher.............. 196

Bismarck (Howe's)........ 149

Bismarck (Greenleaf's).... 170

Bismarck, Jr. (Wangh's)... 145

Bismarck, Jr. (Haskell's)... 161

Blackbird. .............. 256

Blackbird (Sawyer's)...... 295

Black Clyde............. 313

Black Dan. . . . . . . . . . . . . 104

Black. Diamond........... 73

Black Diamond (Lavine's). 267

Black Dina............. 187

Black Donald. . .......... 197

Black Donald (Field's).... . 314

Black Duke.............. 151

Black Dutchman......... 202

Black Eyed Susan........ 192

Black Fearnaught......... 243

Black Harry............. 204

Black Hawk Chief......... 201

Black Hawk Patchen.... . . 232 
Black Hawk Plato....... 316

Black Jacǩ............... 312

Black Jane............... 178

Black Nonitor, .......... 145

Black Norgan........... 94

Black Prince (Hall's) . .. . . . 207

Black Prince (Howe's).... . 261

Black Píince (Bailey's).... 265

Tlack Prince (Hutohins )... 260

Black Prince (Hayes')...... 28:

Black Prince (Bartlett's).... 310

Black Pilot. ............ 304

Blacksmith Belle.......... 239

Blacksmith Maid......... 87

Blackstone Belle......... 54

Black Stranger........... 94

Black Stranger (Hussey's). 150

Black Sal............... 77

Black Sultan............ 137

Black Swan.............. 188

Black Thorn............ 73

Black Topsey............ 289

Blackwing............. 165

Black Walnut............ 78

Black Warrior........... 118

Blane Negre............ 37

Blesbok............... 253

Blimn MLorrill........... 213

Blithsome.............. 252

Bonaficle............... 251

Bounydoon.............. 150

Bonney Hampton..... . . . 229

Bonney's Iinox. . . . . . . . . . 193

Booth................... 284

Bothersome............. 84

Boston Charley...........155

Boston Girl............. 271

Bradford Morrill.......... 223

Brandywine............. 115

Brenda................. 252

Brighthopes.............. 253

Brigham Young (Harvey's) 93

Brigham Young (Libby's). . 233

British Hunter. . . . . . . . . 309

Brown Billy............ 145

Brown Ben............ 145

Brown Bess............. 191

Brown Dick............ 296

Brown Harry............ 200

Brown Nathan............ 119

Brutus................ 166

Buchanan............... 110

Budd Doble............... 224

Buffalo Bill............. 119

Bully Brooks........... 79

Bull-of-the-TVoods......... 119
Burnham Patchen....... 232

Burrongh Boy........... 71

Bush Messenger.......... 27

Bush Messenger, 2d....... 33

Bush Messenger, 3d ...... 31

Bussey's Ińnox.......... 162

Butcher Boy............ 297

Butterball............. 175

Butterfly............... 285

Cadmus................23

Cadmus ................ 303

Cadmus, Jr........... 235

Caledonia................ 316

Call Horse.............. 35

Calvin................ 35

Camors................ 129

Caoutchouc.............. 99

Capitola............... 182

Capitola................ 209

Capt. Atwell........... 88

Capt. Jack............. 263

Capt. Jack............... 208

Captain Jim............. 190

Careless. ................ 186

Carenaught............... 239

Carenaught, Jr......... 243

Carlotta................ 2 11

Carlotta............... 289

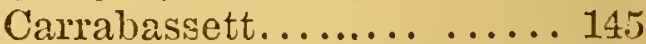

Carthage Boy............. 108

Celia.................. 47

Champion Black Hawk.... 315

Charlie MIorrill. . . . . . . . . . 225

Charlie Ranger............ 291

Champion Irnox.......... 16 J

Charity.................. 247

Chestnut Dick.......... 271

Charcoal................. 286

Chestmut Girl............. 24t

Clara Bell. . . . . . . . . ..... 194

Cleopatra................ 295

Clondman............... 81

Cobbler................ 267

Cobbossee Ínox.......... 167

Colonel Andy ............ 188

Col. Brooksville.......... 72

Col. Dumning........... 139

Col. Ellsworth. ......... 163

Colonel Hampton......... 229

Col. Kling. . . . . . . . . . . . . 154

Col. Inox. . . . . . . . . . . . 159

Col. Lakeman. . . . . . . . . . . . 262

Colonel Lang.............. 149

Col. 'Talbot............... 201

Col. 'Tom. Knox. ......... 141 
Columbus............... 310

Commodore.............. 291

Conqueror, Jr........... 270

Contraband............. 77

Cook Colt................ 160

Cooloo................... 156

Copper Bottom.......... 101

Corimna Boy........... 83

Corinna Maid........... 186

Count Monte Christo....... 164

Country Girl............ 171

Coupon............... 142

Coupon, Jr............ 187

Crazy Jane.............. 182

Cremorn............... 245

Crookneck............... 255

Crown Prince............ 161

Cruiser................. 250

Daisy............... 287

Daniel Boone............ 100

Daniel Drew............. 69

Daniel D. Tompkins........ 38

Daniel Webster.......... 157

Dandy Jack............. 186

Dandy Jim.............. 186

Dan Morrill. . . . . . . . . . . . 224

Dan Sterens........... 82

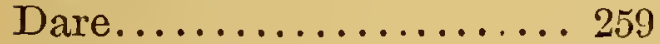

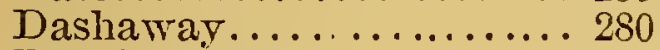

Dashing Charlie.......... 171

David Quimby........... 83

Deceitful. ............. 81

Detective.............. 80

Dexter Boy............. 205

Dexter Morrill. .......... 225

Dick.................. 197

Dick.................. 270

Dick................. 267

Dick Knox. . . . . . . . . . 156

Dirigo................ 62

Dirigo Prince........... 87

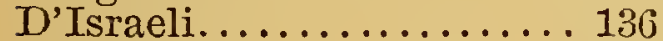

Doctor................ 221

Dodge................. 113

Dolares................ 86

Dolly Gray............... 199

Dolly Varden............ 223

Dolly Varden............ 225

Dolphin................257

Donnybrook............. 160

Don Juan............... 64

Don Pedro............... 168

Dou Quixote............. 86

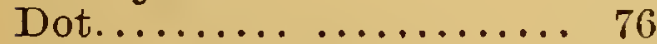

Dotty Dimple........... 192
Draco Chief.............. 293

Draco Princess............ 285

Dresden................ 44

Drew's Knox............. 147

Drew Knox............. 171

Druminond Kñox......... 136

Druid................ 82

Duchess of Lancaster...... 290

Duke Alexis............ 153

Duke of Wellington....... 143

Duke of York............. 308

Dying Sargeant.......... 273

Eady Morrill............ 223

Eastern Belle............ 85

Eastern Boy............ 86

Eastern Boy (Hussey's).... 203

Eastern Boy........... 46

Eastern King............ 228

Eastern Queen................. 167

Eastern Queen............ 78

Eastern Star............ 83

Eaton Horse.............. 91

Echo................. 177

Eclair................... 169

Edgar Allen............ 288

Edgecomb mare.......... 230

Elisha............... 47

Emery Fearnaught....... 240

Emperor................ 79

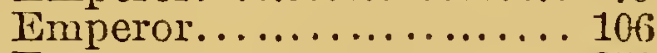

Emperor.............. 254

Emperor William......... 144

Empire................ 155

English Ranger.......... 314

Enterprise............... 236

Enterprise (Milller's) ....... 164

Ethan Allen, Jr. (Hol-

land's).............. 307

Ethan Allen, Jr., (Dolbier's) 307

Eugenie............... 238

Extract from Public laws.. 318

Fairfield Boy.......... 132

Fairfield Knox,......... 138

Fairfield Knox (Cilley's)... 162

Fairfield Knox (Fuller's)... 140

Fairy Bell.............. 193

Fanny............... 222

Fanny Bradbury .......... 286

Fauny Drew............ 86

Fanny Fearnaught........ 242

Fanny Fern............. 247

Fanny Granger.......... 195

Fanny Hathorne.......... 242

Fanny Morrill........... 223 
Fanny Pullen............. 39

Tarmer Boy............... 264

Farmer's Favorite........ 316

Farmer's Messenger...... 32

Farmer Slocum........... 282

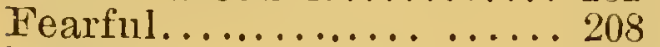

Fearless................. 242

Fearless................. 244

Fearnanght............. 239

Fearnaught Beanty....... 240

Fearnanght Chief......... 243

Feridoon............... 187

Finance................. 151

Flash.................. 229

Fleetfoot................. 86

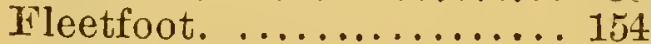

Fleetfoot (Norton's)....... 314

Fleeting Moment.......... 45

Fleetwood................ 216

Fleetwood (Smith's) ...... 203

Flighty................ 292

Flora................... 183

Flora Morrill............ 222

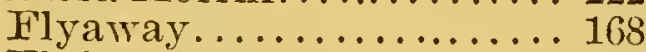

Flying Cloud...................... 144

Flying Eaton.................. 111

Flying Eaton, $\mathrm{J}_{1} \ldots \ldots \ldots \ldots 111$

Flying Gipsey.......... 88

Flying Harry............ 201

Flying Mac............. 36

Flying Roman Boy....... 170

Flying Squirrel.......... 293

Flank.................. 297

Frank Pierce............ 313

Franseer................ 169

Fred Donglass (Crockett's) 188

Fred Douglass............. 153

Frederick Charles........ 168

French Cadmus........... 236

French Tiger............ 260

Fritz.................... 294

Fowler's Brandy.......... 117

Fox................... 75

Garibaldi................ 183

Gardner Knox............ 137

Gay Fearmanght.......... 244

Gazelle................. 66

General (Merrow's)........ 269

General (Holden's)........ 271

Gen. Berry.............. 139

Gen. Dix (Bussey's)....... 152

General Dix (Fish's)...... 94

Gen. Franklin.......... 162

Gen. Gariballi.............

Gen. Grant (Grant's )....... 52
Gen. Grant (Robinson's)... 65

Gen. Grant (Choate's)...... 67

Gen. Grant (Proctor's)..... 65

Gen. Grant (Gilbert's)... . 169

Gen. Grant (Stackpole’s)... 223

Gen. Grant (Chase's). . . . . . 202

Gen. ITancock............ 72

Gen. Howe... . . . . . . . . 185

Gen. Howe, G. . . . . . . . . 152

Gen. Jackson............ 200

Gen. Inox. . . . . . . . . . . . 123

Gen. Knox, Ji........... 138

Gen. Knox, J1. (Larkin's). . 149

Gen. Lee................. $14 t$

Gen. Lightfoot............ 130

Gen. Lightfoot (Lovejoy's) $26 \pm$

Gen. Lyon (Shaw's)........ 68

Gen. Lyon (Palmer's)...... 68

General Lyon (Lyon's)..... 171

Gen. McClellan.......... 61

Gen. Scott.............. 83

Gen. Sherman........... 110

Gen. Sherman (IVood-

ward's ) ............. 136

Gen. Taylor............. 41

Gen. Valejo............ 70

Gen. Warren..... ...... 288

Gentle Anuie.......... 76

Gentle Amnie (Inice's)..... 246

Gentle Kitty............. 290

Gentle Nellie............ 190

Gentle Flora............. 295

Georgie B.............. 81

George B. McClellan....... 62

Gideon................. 306

Gideon, Jr.............. 247

Gifford Patchen......... 232

Gilbert................. 233

Gilbreth Knox. ......... 128

Gilbreth Knox, Jr....... 165

Gilbreth Prince.......... 146

Gipsey.................. 289

Gipsey Girl............ 89

Gipsey Naid............. 89

Gipsey Queen........... 76

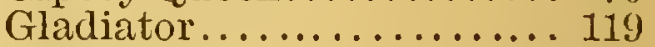

Glengarry................ 216

Goding's Brandy . . . . . . . 117

Gold Bird.............. 116

Gold Hunter............. 174

Golden Messenger........ 265

Golden Robin........... 256

Gopher................. $6 t$

Gray Eagle................ $3 t$

Gray Fearnaught......... 305

Gray Jacket............. 223 
Gray Rose............. 140

Gray Stranger............ 99

Green MIountain MIaid..... . 286

Green MIountain MIorrill... 311

Gretta................. 290

Grey Lion... . . . . . . . . . . 309

Hampden Boy........... 66

Hampton............... 226

Hampton, Jr........... 229

Hampton (Bonney's)... . . . 2 239

Hamlet............... 113

Hard Road............... 79

Hardy's Ínox............. 161

Harry Slip............. 247

Harry Spanker.......... 176

Haskell Horse............ 229

Hattie................... 242

Havelock.................. 309

Hazel Eye............. 250

Hector................ 262

Helen................... 297

Henry................27t

Henry Claf............. 315

Henry Wilson.......... 151

Hiawatha............... 154

Hickors.................. 31

Highland Boy............ 184

Highland Patchen.......... 231

Hillman's Knox......... 161

Hind's Knox............ 145

Hirain................ 163

Hiram Drew............ 63

Hiram Dyer............. 58

Hiram Morrill. .......... 216

Hiram Woodruff......... 170

Homan Horse.. ......... 34

Honest Ben............. 35

Honest Bill.............276

Honest Harry. . . . . . . . . . 225

Honest John. . . . . . . . . . 133

Honest John (Jones').... . 155

Honest John (Briggs'). . . . 163

Honest John, Jr......... 166

Honest Quaker.......... 75

Horace Greeley........... 289

Houlton Maid. . . . . . . . . . . 291

Howe's Bismarck. . . . . . . . . 149

Hunter................. 187

Hunton Horse.......... 27

Huntsman.............. 85

Fiummingbird........... 197

Ice Pony............. 275

Imported Annfield........ 237

Ilderim................. 241
Independence............ 89

Independence............ 273

Independence (Merrow's) . . 296

Independent Boy......... 154 Indlependent Knox (Crockett's).............. 167 Independent Innox (Wilson's )............... 167 Independent Gel.. Knox... 147 Indian Chief............ 246 India Rubber John........ 64 Ink. .................. 282 Irish Mae............. 147

Jack of Hearts.......... 215

Jas. G. Blaine............ 259

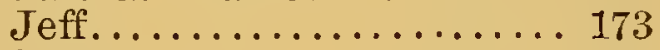

Jenny................. 190

Jenny Lind. . . . . . . . . . . . . 295

Jenny Wren............ 191

Jessie Ridgley. ........... 253

J. H. Gilbreth........... 166

Jim Crow.............. 202

Jim Fiske............... 67

Joaquin............... 166

Joe Hooker.............. 70

Joe Hopkins. . . . . . . . . . 221

Joe Jefferson............. 24ว

Joe Morrill. . . . . . . . . . . . . 214

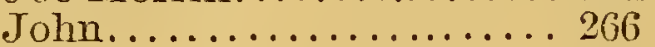

John. ................ 316

John Bright. ............. 63

John Bunyan........... 222

John B. Dunton.......... 28

Joln Franklin........... 112

John Knox............. 166

John Murray............ 283

Jolmn Neptune........... 189

Johnny O'Brien........... 196

Johnny Morrill........... 307

Johnny Schmoker......... 81

Johnny Schmoker........ 155

Jolly Boatman............ 67

Joseph R. Conant......... 287

Judge Advocate........... 248

Jule................... 232

Jules Jurgensen. . . . . . . . 134

June Bug.............. : 189

Juniper... ............ 141

Juno, 2d............... 198

Justin MIorgan. . . . . . . 49

Krate................. 277

Kate Gilbert.............. 206

Kenduskeag Boy.......... 265

Kennebec.............. 33 
Kennebec Chief.......... 158

Kennebec IKnox............ ¿96

Kennebec Messenger

(Blake's)............. 31

Kennebec Messenger.

(Beal's).

Kentucky Boy............... 304

TǨentucky Prince.......... 295

Kettlebail............... 57

King Bird............... 197

Kineo................... 300

King Drew.............. 67

King Herod.............. 36

King Herod (Soule's)..... 315

King Hiram ............. 228

King Philip.............. 228

King Philip.............. 164

King's Patchen........... 233

King William........... 226

Irit Carson.............. 80

Kitty................... 168

Kitty Knox............. 198

Knights Horse........... 258

Knox Boy (Carr's)........ 141

Knox Boy (Cleaveland's). . 160

IKnox Boy (Lee's).......... 173

Knox, Jr.............. 137

Knox Maid............... 189

Knox Morrill............ 213

Knox Telegraph........... 142

IKnox Queen............ 174

Lady Ada Duleth......... 294

Lady Anna............ 120

Lady Belle............. 89

Ladly Berry............. 109

Lady Bradford........... 101

Lady Burleigh........... 120

Lady Chapman........... 57

Lady Damon.............. 120

Lady Danforth............ 193

Lady DeMerritt.......... 189

Lady Diamond............ 242

Lady Dillon.............. 76

Lady Draco............... 293

Lady Ellsworth........... 84

Lady Ellsworth. ......... 198

Lady Fairfield............ 107

Lady Franklin............. 114

Lady Fearnanght......... 243

Lady Gay Spanker........ 260

Lady Gideon... .......... 250

Lady Hamilton............ 205

Lady Hamlin............ 55

Lady Hampton ........... 229

Lady Hudson............. 293
Lady Kildare............ 194

Lady Knox.............. 178

Iady Knox............. 180

Lady Lang. . . . . . . . . . . . . 190

I Lady Ledo............... 249

Lady Lee............... 189

Lady Leo................ 184

Larly Littlefield........... 195

Lady Mac............... 88

Lady Mansfield............ 181

Lady Mand............... 127

Lady Mand.............. 181

Lady May.............. 222

Lady Minoken............ 243

Lady Morris............. 282

Lady Oxnard.. ......... 260

Lady Packer............... 48

Lady Palmer............. 246

Lady Pilot .............. 285

Lady Quimby............ 85

Lady Snell............... 225

Iady Speedwell............ 195

Lady Stratton............. 188

Lady Swan............... 274

Lady Taylor............... 220

Lady Walton.............. 46

Lady Warren............. 77

Lady Winfield............. 248

Lambert.................. 118

Lancaster.............. 302

Lancet................. 241

Leadaway............... 156

Leader................... 152

Leavitt Horse............ 31

Ledo..................... 143

Ledo, Jr............... 249

Leeds................... 121

Leo..................... 138

Leon...................... 264

Leslie Colt................. 172

Lewiston Boy............ 55

Lewiston Knox........... 171

Lewiston Lady............ 57

Lew Pettee............. 280

Iexington. .............. 163

License.................. 275

Lion................... 28

Lion................... 313

Lion Messenger........... 36

Lisgar.................... 63

Little Bill.............. 186

Little Clande............. 71

Little Clyde............. 87

Little Ed................. 179

I.ittle Fred................ 87

Little Fred............... 73 
Little Fred (Otis)......... 158

Littlefield Colt.......... 165

Littie Mac.............. 205

Lively Lass.............. 244

Lively Times............ 179

Live Oak.............. 312

Lizzie Keeler. . . . . . . . . . . . 199

Lookout................ 197

I.on Morris.............. 141

Lothair................. 129

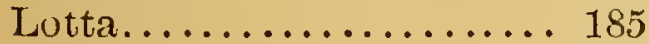

Lucy Knox $\ldots \ldots \ldots \ldots \ldots . . .196$

Lula................. 186

Mac.................. 53

Mabel.. ................. 194

Madawaska Maid. . . . . . . 277

Irailame Parepa.......... 205

Nadockawando............ 301

Maggie................... 294

Maggie May.............. 195

NLaggie Quimby.......... 89

Maine Duroc............. 248

Maine Eclipse............ 235

Maine Girl.............. 82

Maine Hambletonian... . . . 249

Míaine Slasher.......... 132

Major Chism............. 288

Major Knox............. 151

Major Knox (Boody's)..... 157

Mambrino Bishop........ 292

Manchester.............. 239

Mary Drew............. 75

Martin McClellan......... 83

Matchless................ 50

Mand Muller............. 121

Mand Muller.............. 194

Mand Richmond. ........ 194

May Boy............... 270

May Day .............. 238

May Day............... 244

Mayflower.............. 88

Mĩaflower.............. 195

May Queen............ 234

Míazeppa................. 114

McClellan, Jl.......... 66

Mermaid............... 190

Merrow Horse........... 33

Messenger Hunter....... . 310

Messenger Bonus........ 30

Messenger Knox.... ...... 133

Messenger Prince......... 228

Metacomet.............. 168

Middy Morgan............ 166

Mignonette............ . 230

Milder.
Milinokett ............ 162

Mineada (should be Mineola).............. 88

Minnehaha.............. 182

Minot................... 148

Mocking Bird. . . . . . . . . . 109

Modoc................. 218

Modoc Boy............. 241

Modoc Chief............. 243

Mohawk............... 157

Monarch.................. 214

Monmouth Knox......... 136

Nonogram............. 292

Montgomery Ḱnox....... 155

Moody's Messenger....... 35

Norgan Billy............ 58

Morgan Cresar........... 49

Morgan Eclipse.......... 52

Morgan Rat............. 50

Morgan Rattler.......... 50

Morgan Trotter.......... 50

Morrill Boy............. 224

Morrill Chief............. 314

Morrill Knox........... 174

Morrell Knox............ 160

Morrill Maid............. 224

Morrill Prince............ 214

Morrill Prince (Hersey's)... 308

Morris Colt............ 178

Mt. Vernon............ 92

Mumin................. 220

Music.................. 181

Myra Shaw............ 176

Nabocklish.............. 105

Napoleon............... 201

Ned Davis........... .. 64

Nellie Briggs............ 177

Nellie Burton........... 101

Nellie Clipper............. 198

Nellie Drew...... ........ 89

Nellie Grant............ 84

Nellie Kling. . . . . . . . . . 196

Nellie Knox............ 174

Nellie Mayo............. 297

Nellie IIorrill. . . . . . . . 101

Nellie Otis.............. 219

Nellie Palmer............ 84

Nelly Knox............. 196

Neptune.............. 158

Nettie ................ 85

Nettie................. 206

New Portland Boy........ 160

Norman Roger............ 268

Norman Tiger............ 270

Norridgewock. ........... 139 
Norridgewock Boy........ 169

Nortliern Spy. ........... 180

North Star.............. 204

Norton's Hambletonian. . . . 314

Oalss Horse............. . 93

Old Drew............... 60

Old Probability.......... 153

One Eye.............. 179

Orland Boy ............... 308

Orphan Boy. ........... 8.

Orphan Boy............. 116

Othello.................. 138

Otto Von Bismarck....... 299

Oxford Boy............. 230

Padds................. 58

Palmer Kinox........... 132

Pauic.................... 250

Parker's Mressenger....... 95

Passamaquoddy Girl. ...... 208

Pat ...................... 10t

Patchonli............... 23:3

Pat. Malloy. ........... 293

Patty IV............... 120

Panl Clifford............... 317

Pelham................278

Penobscot Boy.......... 263

Penobscot Chief.......... 69

Pet................... 87

Pequawket.............. 246

Phantom............. 113

Phillip Morrill......... 215

Plil. Sheridan........... 131

Phil. Sheridan ........... 283

Pillsbury Inox. . . . . . . . . 172

Pishon Horse............ 32

Pitt Fessenden. .......... 113

Plato................. 13.

Plato, Jr............... 185

Playaway.............. 142

Plongh Boy............ 66

Plow Boy............... 268

Plow Boy.............. 122

Pluto................... 15:

Plymouth Riock......... 175

Pollard Morgan........... 51

Polly Perkins........... 81

Pomp................ 282

Portland................. 296

Post Boy................. 273

Prescott's Innox........... I40

Prince.................. 566

Prince................... 310

Prince Albert........... 166

Prince Albert, $\mathrm{J}_{1} \ldots \ldots \ldots \ldots . .271$
Prince Bismarck......... 58

Prince Elward........... 173

Prince Edward. ........... 312

Prince Hal.............. 65

Prince Harry............... 201

Prince Messenger......... 51

Prince William.......... 228

Princess................. 288

Princess. ................ 236

Princess Dagmar............. 292

Princess Lonise. . . . . . . . . 192

Prize.................... 180

Prndy................. 196

Purity................. 220

Queen Bess. . ........... 290

Queen Mab.............. 290

Queen Victoria........... 168

Quicksilver.............. 254

Quimby Messenger........ 27

Ranger................ 143

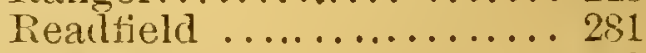

Real Istate............. 172

Reckless............... 216

Red Cloud ............. 93

Red Jacket ............. 69

Red Oak, Jr............. 311

Fed luver.............. 86

Reliance............... 145

Ii. E. Lee. . . . . . . . . . . . . 157

Revenue............... 109

liex ............... 162

Ricker Innox............ 181

Ridley's Innox ........... 136

Rising Stun.............. 10.

Rising Stn............ 88

Robert Bonner.......... 150

Robert Burns............ 250

Rob Roy................ 181

Rob Roy (D'A A thenay's)... 309

Robinson Knox........... 170

Rocket............... 268

Rocklanıl Maid............ 188

Rollins Hor'se......... . 103

Rollins' Knox........... 156

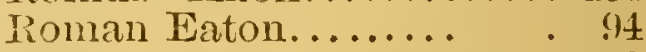

komeo................ 73

Pondo Innox............ 163

liosalie................. 208

Rosa Ínox.............. 190

Rose of Sliaion........... 101

Roving Lady............. 291

Royal George............. 147

lioyal Ínox............. 153

Royal Oak............. 32 
Royal Tanuer........... 142

Rubicon................. 204

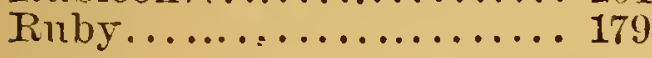

Sable.................. 183

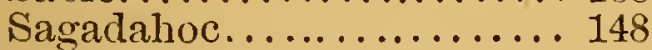

Sally-Come-Up............ 108

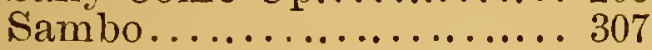

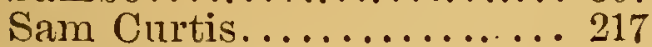

Sam MLorrill............. 221

Sandy River Boy......... 146

Sandy River Horșe........ 92

Sanford Knox............. 158

Saturn ............... 184

Scientella............... 198

Scotch Morgan............ 308

Scythian............... 301

Seeboomook.............. 251

Selim Fearnaught......... 240

Shagbark................ 291

Shaker Drew............ 73

Sharon............... 112

Shaw's Knox............. 169

Shepherd F. Knapp........95

Shepherd Knapp, Jr., ..... 96

Sherman Irnox.......... 317

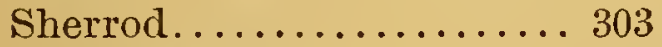

Shooting Star............ 174

Shooting Star............. 112

Shores Mressenger......... 30

Silverheels............. 84

Singed Cat............ 172

Sir Edwin ................ 298

Siroc.................. 72

Skedaddler............. 45

Skowhegan Boy........... 135

Slasher................ 156

Slippery Sally........... 90

Smuggler............... 179

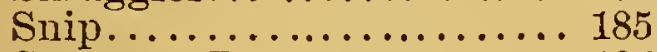

Somerset Boy............ 187

Sorrel Hiram. . . . . . . . . . 272

Sorrel John............. 48

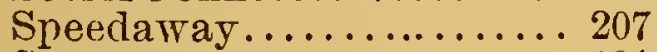

Spruce................ 191

Stagnation............... 182

St. Elmo............... 140

St. Elmo............. 205

St. Lawrence............. 309

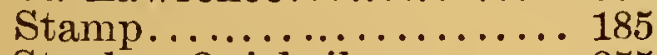

Stanley Quicksilver....... 255

Star Knox.............. 152

Starlight............... 156

Starlight.............. 182

Starr King............... 150

State of Maine .......... 29
State of Maine........... 297

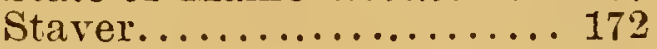

Stella................ 74

Stome Horse............ 30

Stony Brook Belle......... 294

Sultan................ 302

Sultan Junior............ 133

Sultan Knox.............. 185

Sumbeam................ 224

Sunrise............... 183

Susie.................. 56

Sweet Briar. . . . . . . . . . 219

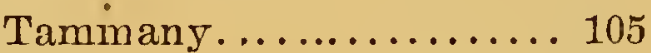

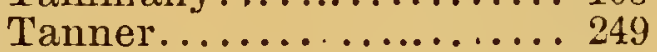

Ternpest.............. 75

Thurlow Knox............ 184

Tiger Drew............ 71

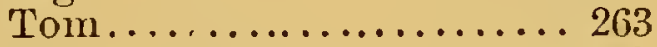

Tom Benton.......... 42

Tom F. Patchen.......... 233

Tom Hyer............. 114

Tom Hyer. ............ 183

Tom Lang.............. 139

Tom Lang, Jr........... 143

Tom Moore............ 197

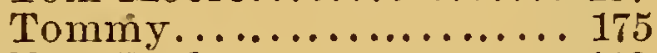

Tom Parker............ 112

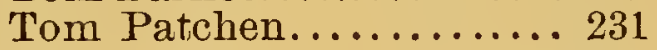

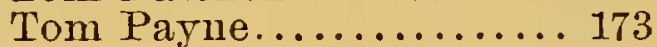

Tom Thumb........... 117

Topsy. . ............ 192

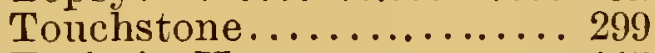

Tozier's Knox........... 147

T. K. Allen........... . 288

Triumph.............. 249

Trotting Billy ............ 269

Troublesome............. 94

Troublesome............ 285

Troublesome Cricket...... 83

Troublesome Knox....... 144

Troublesome Trapper. .... 292

Trustee Messenger........ 34

T. S. Lang. ............. 134

T. S. Lang, Jr. . . . . . . . . . 157

Uncle Sam; formerly Quaker General ............ 142

Uncle Shube............ 148

Valley Knox............ 170

Van Amburgh............ 268

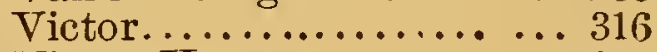

Victor Hugo............. 294

Victoria................ 207

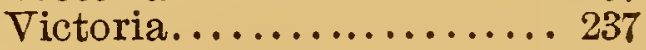


Victcria Parsons.......... 192

Village Maid.............. 100

Violet..................... 248

Virginia Boy............... 203

Voltaire................. 165

Von Moltke.............. 68

Vulcan................ 213

Webster Boy............ 267

Wellington Boy............ 271

Wellington Knox.... ..... 149

West Gardiner Bоу........ 158

West Hurse..................... 313

Whalebone (Clark's)...... 51

Whalebone............ 5I

Whalebone Knox......... 148

Whalebone.................161

What Is It. .......... 100

Whirlpool................. 153

Whirlpool................ 284

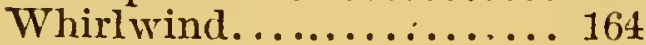

White Colt............. 187

White Oak............. 183

Whitenose.............. 121

White Stockings......... 46

White Stockings......... 196

Whiz................. 152

W. H. Taylor........... 279

Wild Nellie............ 182

Wild Prairie............. 87

Wild Rose................ 188

Winthrop (Greene's)...... 70

Winthrop (Wright's)....... 213

Wintlirop Ínox......... 173

Winthrop Messenger...... 25

Winthrop Morrill......... 210

Winthrop Morrill, Jr. (Cotton's ).............. 211

Winthrop Morrill, Jr., (Haywood's)............ 224

Witherell Horse........... 28

Woodbrook Messenger.... 36

Woodford Knox........... 154

Woodstock Boy.......... 310

Worromon togus........... 173

Xingtr................. 290

Yankee Boy............ 67

Young Abe............. 267

Young America.......... 104
Young Annfield.......... 238

Young Brandy wine....... 115 Young Brandywine

(Prince's)............ 118

Young Brchanan......... 266

Young Burbank.......... 50

Young Champion......... 315

Young Danville Boy...... 265

Young Defiance........... 280

Young Dexter............ 250

Young Dirigo (Strattard's). 70

Young Dirigo (Carpenter's) 72

Young Dirigo (Brooks').... 82

Young Draco............ 293

Young Draco Prince...... 306

Young Ethan........... 305

Young Ethan Allen. . . . . . 269

Young Ethan Allen........ 287

Young Fearnaught........ 240

Young Gen. Knox........ 159

Young Gifford Molgan..... 311

Young Gilbreth Knox...... 146

Young Hambletonian .... 251

Young Hardrow......... 269

Young Hogarth. ......... 258

Young Indian Chief....... 261

Young Knox........... 164

Young Knox, Jr........ 159

Young McClellan (Robin-

son's).............. 65

Young McClellan (Petten-

gall's $). \ldots \ldots \ldots \ldots \ldots$. 65

Young MLrgan Othello.... 52

Young Morrill............ 216

Young Morrill, Jr......... 215

Young Ruler.............. 308

Young Ruler........... 263

Young Sky Lark. . . . . . . . . 304

Young St. Lawrence....... 312

Young Siffolk........... 37

Young Telegraph........ 202

Young Tobin........... 103

Young Warrior.......... 255

Young Winth'p Messenger. 37

Young Wintlirop Morrill... 214

Zac Taylor............. 41

Zainor..................265

Zenobia................... 185

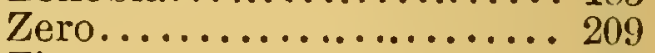

Zig.................. 184 


\section{HOIT\& $\mathrm{HOGG}$}

No. 91 Middle Street,

\section{PORTLAND,}

PUBLISH THE FOLLOWING VALUABLE WORKS:

Barth's Chromological Comientary.

By Rev. C. G. Barth, D. D., Germany. Imperial octaro. 1000

pages. Half Morocco, $\$ 6.50$; Sheep, $\$ 600$; cloth................ $\$ 5.00$

The Seals Opened; or, The Apocalypse Explanned. By Rev. E. Pond, D. D., Professor in the Theological Seminary,

Bangor. Cloth, crown $8 v 0.240$ pages... ................... 1.50

THese for THose: OUR InDebtenness to Missions. By Rev. William Warren, D. D., Dist. Sec. of American Board. Cloth, 12 mo. 420 pages.................................... 1.50

Rays of Light; or, Church Themes and Life Problems. By Rev. John Philip, M. A., Scotland. Cloth, 12mo. 294 pages. . 1.50

HeLps AT THE Mency SEAT.

Prayers from the Scriptures, Old Divines, and the Poets. Cloth extra, square $24 m o$, gilt and red edges. 272 pages............... 1.50

LILY HoPe AND HER FrIENDS.

A Tale. By Hetty Bownan. Cloth, 12mo. 268 pp. Illustrated.. 1.50

The Carpenters' Aind Builders' Guide.

Being a Hand-book for Workmen. Also, a Manual of Reference for Contractors and Builders. By P. W. Plummer. 8vo. 72 pages, with plates. Price, half bound............................ 1.00

Hints Aвout Business.

A Manual of Business Laws, Customs, and Methods. Also, containing Fac-simile Forms of Business and Legal Papers. 16mo, cloth, $75 \mathrm{c}$; ; half bound...................................... $\quad .50$

To Roslin; From the Far West.

Cloth, 16mo. 119 pages. Illustrated....................... .75

Maine State Year Book and Annual Register For $1874-5$. $16 \mathrm{mo}$. 512 pages. With colored town and R. R. Map, 13 by 16 inches. Cloth, with Map........................... 1.25

HisTory OF WINDHAM.

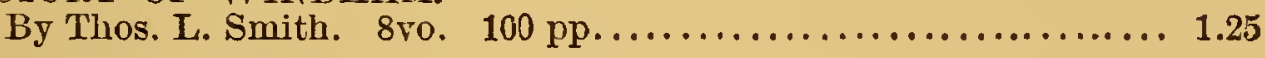

History OF MToNson.

A Centennial Address. 8 то. $48 \mathrm{pp} \ldots \ldots \ldots \ldots \ldots \ldots \ldots \ldots \ldots \ldots . .25$ 


\section{JUVIENILES.}

How Benaie Did It.

By Matthew Merchant. Clotl, 16mo. 440 pages. Illustrated....\$1.50

Twerve Years With The CHLdRex.

By Rev. William Warren, D. D., Dist. Sec. of A merican Board.

Cloth, $16 \mathrm{mo} .324$ pages. Second edition. Illustrated.......... 1.25

The Melvill Faimly and their Bible Readings.

Cloth, 16 mo. 232 pages. Illustrated.................... 1.00

Choice Stories.

Cloth, 24 mo. 192 pages. Illustrated..................... 60

LigitT FOR LITTLE ONES.

By Iary F. Waterbury. Cloth, 18mo. 67 pages. Illustrated.... .50

Slippery Paths. A Temperance Story.

By Mrs. C. W. D. Strout, Auburn. Cloth, 18mo. 72 pages. Illus-

trated............................................ . 50

\section{- JUVENILES IN SETS.}

The Hazelwoor Series. 4 volumes, cloth, $16 \mathrm{mo}$...\$6.00

1. Horace Hazelwood, and other tales. 328 pages. 27 lllustrations.

2. MISS MATTr, and other tales. 328 pages. 30 Illustrations.

3. Tue White Roe of Glenuere, and other tales. 312 pages. 35 lllustrations.

4. FOUND AFLOAT, and other tales. 328 pages. 30 lllustrations.

The Melborme Series. 4 volumes, cloth, 16 mo....\$2.80

1. LINDSAY LEE. 112 pages. Illustrated.

2. AUNT Margeri's MAXIMS. 112 "6 "

3. COTTAGERS OF GLENCARRAS. 112 "6 "6

4. MARY BRUNTON.

112 "6

"6

The Treastre Series. 6 volumes, cloth, 24 mo.....\$2.50

1. THE SANGREAL.

2. Nothing To Do.

3. The LitTle DOVE.

4. RICHARD BLAKE.

5. ALICE LOWTHER.

6. The little Captaix. 95 pages. Illustrated.

$\begin{array}{lll}96 & \text { 66 } & \text { 66 } \\ 96 & \text { 66 } & \text { 66 } \\ 96 & \text { 66 } & \text { 66 } \\ 96 & \text { 66 } & \text { 66 }\end{array}$

\section{SUNDAY SCHOOL CONCERT EXESCIESS.}

Colloqui on Heaver... .............................. 03

RAINBOW Exercise.................................... 03

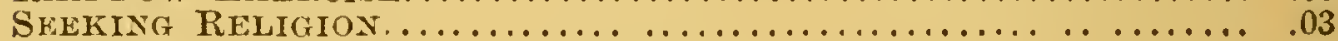

ANGEL IN THE SUNDAY SCHOOL............................ 03

Christilas Lights. ................................... 05

Curistianna and her Children..................... 10

IMPRoved S. S. Class Books, per dozen................... .75

UNion Lesson PAPERs, per hundred, per year................. 9.00

Large variety of Sunday School Rewards of all prices.

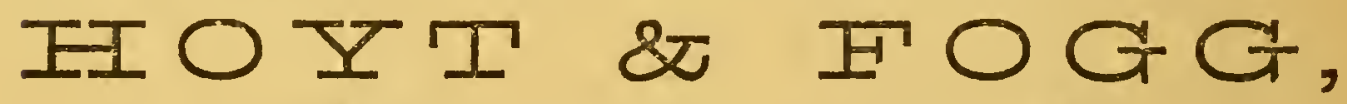

91 Middle Street, Portland, Me. 


\section{HOYT \& FOGG'S Graduated Check Rewards,}

FOR THE

\section{GOVERNMENT OF. SCHOOLS,}

AND

\section{EXACT RANKING OF EACH SCHOLAR.}

A "Perfect," ranking two "Merits," is secured for perfect attendance and deportment, neatness, studiousness, and good recitations.

An "Imperfect," ranking one "Merit," is secured for an excusable failure in auy of these particulars.

The forfeiture of a claim to either ticket will result from an inexcusable failure in any of these particulars, or may be assigned as a punishnent for any special neglect or disurder.

"Perfect," secured each day in the week will secure an "Exchange Check" at its close, four of which Exchange Checks wili be exchanged fir a "Certificate," marked "40 Merits," at the close of the month, or these may be secured at any time for the rquisite number of Merits.

A Diploma, Bo k, or other present, may be given at the ciose of the term, for a ny assigned number of Certificates.

Price List.-Each box or set contains 256 Perfects, 224 Imperf cts, 80 Excinange C-ecks, 16 Certificates. Beautifully tinted Bristol bcard. Price 75 cents. Packages of 200 Porfects, 25 cents. Packages of $200 \mathrm{Im}$ perfects, 25 cents. Packages of 100 Exchange Lhecks, 25 cents. Yackages of 25 Certificates, 25 cents. Large Diploma, printed in colors and gold, suitaule for framing, $5 \mathrm{cts}$. each, or $50 \mathrm{cts}$. per doz.

Weekly Scholl Reports......................... 30 cts. for 50

Goud Bebavior Certificates............................. 30 cts. fi $\mathbf{r} 50$

Recitation Cards fur 11 or 22 weeks...................... 30 cts. for 50

Large Certificates of Perfect Lessons, fancy colors, 10 cards.........10 cts.

Colored Card Rewards, put up in packages of 10 cards, for 6, 8, 10, 12, 15, 20,2535 , and 50 cts. per package.

American Birds Sea Birds, Tropical and nther Birds, Birds of Prey, Scenes in the Holy Land, Christianna and her Children, People of Europe, Pilgrim's Progress. put up with 12 cards, printed in beautiful uil colors, $4 \frac{1}{2}$ by 6 inches, with letter press on back,................ Bible Text Cards, very net....................130 cards fir 25 cts. Picture Cards, with Hymn..................... Sunday School Poetry Reward Cards..............50 cards fur 25 cts.

SCHOOL REQUISITES of every description, sent by mail, post-paid.

SEIVD FOR OUR CIROUIARS. 


\section{SECOND EDITION NOW READY.}

\section{EVERT TOUIJG MAIJ}

SHOULD HAVE A COPY OF

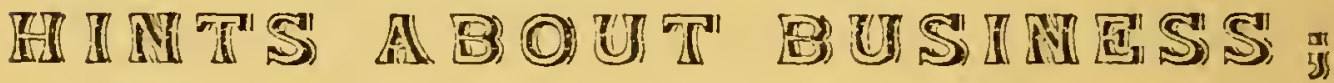

A Manual of Business Laws, Customs, and Methods, familiarly explained. It contains

\section{SHIPPING.}

Filling Orders, Bill of Parcels, R. R. Receipts, Steamer Receipts, Bill of Lading, Express Receipt, "Collect on Delivery," Receipt for delivery of goods, "Blotter," Invoices, Custom-house Entry, Marine Insurance, Goods in Bond.

\section{BOOK-KEEPING.}

Books required, Bank Account, Bank Deposit slip, Check Book, Bill Book, Monthly Statement Book, Memorandum Book, On Sale Book, Petty Cash Book, Statement of Account, Draft Drawn, Note Discounted, Cashier's Check, Bill of Exchange, Draft Accepted, Bank Notice, Borrowed and Received, Bank Check, Collecting Accounts, Paying Accounts, Receipt, Power of Attorney, Method of finding the date when a note falls due.

\section{CORRESPONDENCE.}

Business Letter, Process of Copying Letter, Foreign Correspondence, Inquiries for Terms, Remitting Funds, Opening Letters, Counterfeit Money, Order Book.

\section{MERCHANT.}

Lease, Fire Insurance, Contract, Advertising, Interest, Financial Estimate, Account of Stock, Commercial Agency, Bankrupt Law, Corporations.

\section{PARTNERSHIP.}

Kinds of Partnership, How Formed, Power of one to bind all, Articles of Partnership, Indebtedness of Individual Partner, Dissolution of Partnership.

\section{FORMS OF BUSINESS PAPERS.}

Articles of Partnership, Bank Check, Bank Deposit Slip, Bill of Exchange, Bill of Lading, Bill of Parcels, Bill of Sale, Bond, Borrowed and Received, Business Letter, Draft, Inward Foreign Entry, Lease, Mortgage Deed, Note, Power of Attorney, Receipt, Railroad Receipt, Steamer Receipt, Statement of Account, \&c.

Price, in Cloth, 75 cents; boards, 50 cents.

\section{HOYT \& FOGG, Publishers, Portland.}






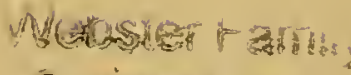

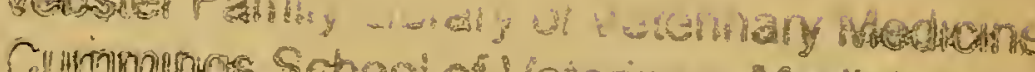

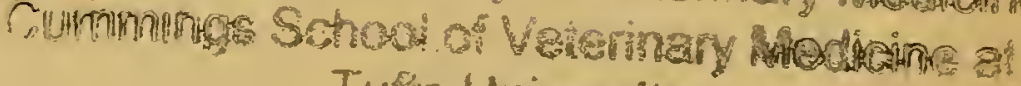

Tuns University 200 Wrestworo Poad Mrath Givafion MA DISSG 
